\title{
WestVirginiaUniversity
}

THE RESEARCH REPOSITORY @ WVU

Graduate Theses, Dissertations, and Problem Reports

2016

\section{Walking Out of Step: U.S.-Israel Relations and the Peace Process, 1967-1975}

Kenny Kolander

Follow this and additional works at: https://researchrepository.wvu.edu/etd

\section{Recommended Citation}

Kolander, Kenny, "Walking Out of Step: U.S.-Israel Relations and the Peace Process, 1967-1975" (2016). Graduate Theses, Dissertations, and Problem Reports. 6001.

https://researchrepository.wvu.edu/etd/6001

This Dissertation is protected by copyright and/or related rights. It has been brought to you by the The Research Repository @ WVU with permission from the rights-holder(s). You are free to use this Dissertation in any way that is permitted by the copyright and related rights legislation that applies to your use. For other uses you must obtain permission from the rights-holder(s) directly, unless additional rights are indicated by a Creative Commons license in the record and/ or on the work itself. This Dissertation has been accepted for inclusion in WVU Graduate Theses, Dissertations, and Problem Reports collection by an authorized administrator of The Research Repository @ WVU.

For more information, please contact researchrepository@mail.wvu.edu. 
Walking Out of Step:

U.S.-Israel Relations and the Peace Process, 1967-1975

Kenny Kolander

Dissertation submitted to the Eberly College of Arts and Sciences

at West Virginia University

in partial fulfillment of the requirements for the degree of

Doctor of Philosophy

in

History

James F. Siekmeier, Ph.D., Chair

Elizabeth Fones-Wolf, Ph.D.

Ken Fones-Wolf, Ph.D.

Joseph Hodge, Ph.D.

R. Scott Crichlow, Ph.D.

Department of History

Morgantown, WV

2016

Keywords: Foreign Relations; Israel; Peace Process; Special Relationship;

Weapons Sales; Arab-Israeli; Congress

Copyright 2016 Kenny Kolander 


\section{ABSTRACT \\ Walking Out of Step: \\ U.S.-Israel Relations and the Peace Process, 1967-1975}

\section{Kenny Kolander}

This dissertation explores the development of U.S.-Israel relations during a crucial period - the Presidencies of Richard Nixon and Gerald Ford, 1968-76. This was a crucial period because U.S. aid to Israel skyrocketed during these years, especially military aid. Importantly, U.S.-Israel relations are examined not only through presidential policies, which other scholars have done, but also through congressional activity. Congress consistently pushed both Presidents to sell more and more weapons to Israel, which would allow the U.S. to project strength abroad during the Cold War - especially given the deteriorating situation in Vietnam - and create job opportunities at home during the hard economic times of the 1970s. Yet the White House resisted as it was leading delicate negotiations connected to the Arab-Israeli peace process. This dissertation discusses how the U.S. Congress used the issue of weapons sales to forcefully challenge White House diplomacy connected to the peace process. Over the course of the NixonFord years, the White House consistently sought to use the threat of withholding aid from Israel, especially military aid, to get Israel to be more "flexible" in peace negotiations in the region. Thus, congressional activity had a two-pronged effect - it substantially strengthened the U.S.Israel relationship through weapons sales, and also weakened the ability of the White House to facilitate peace agreements. 


\section{ACKNOWLEDGEMENTS}

I am indebted to so many people who have helped me get to this point, and especially my dissertation committee - Dr. James Siekmeier, Dr. Elizabeth Fones-Wolf, Dr. Ken Fones-Wolf, Dr. Joseph Hodge, and Dr. Scott Crichlow. Thank you all for your valuable time and feedback. I am especially thankful for my chair and advisor, Dr. Siekmeier. Dr. Siekmeier's expertise, guidance, and friendship played a crucial role in the completion of my dissertation, and my development as a professional historian. A special thank you goes to Dr. Thomas Schwartz at the University of Vanderbilt for being an "unofficial" member of my dissertation committee, and for the invaluable help along the way. And thanks also to Dr. Craig Daigle at the City College of New York for your expert advice about my work.

To the many professors in the History Department at WVU with whom I have taken classes, thank you for enhancing and enriching my understanding of history. In particular, thank you to Dr. Elizabeth Fones-Wolf and Dr. Joseph Hodge, along with Dr. Siekmeier, for your unwavering support every step of the way. The WVU History Department generously funded much of the research necessary for writing my dissertation - research trips to Presidential libraries, archives holding papers of individual senators, and especially my trip to the Israel State Archives in Jerusalem. The WVU Eberly College of Arts and Sciences also contributed funding for several research and conference trips. As a Ph.D. student, it means so much to have financial support. The Gerald R. Ford Presidential Foundation also funded two research trips to the Gerald R. Ford Presidential Library in Ann Arbor, Michigan. The first came while I was working on my M.A. at the University of Kansas, and the second while a Ph.D. student at WVU. An additional, heartfelt thank-you to Dr. Theodore Wilson at the University of Kansas for your willingness to go out of your way to help me when I really need it. Thank you also to Dr. Donald Worster, Dr. 
Paul Kelton, and the History Department at KU. Finally, thank you to West Virginia University for the support of the Arlen G. \& Louise Stone Swiger Doctoral Fellowship, as well as the WVU Foundation Distinguished Doctoral Fellowship.

I would not be here without my parents, Myron and Janice Kolander. Their love and support have been central to my life and vital to my success. I am so proud of my son, Luke, and also very thankful for the many ways that he brings joy to my life. Thank you to Kyle, my brother, and Kari, my sister, for always looking out for your little brother. My grandmothers Elvera Eckert and Elaine Kolander continue to shower me with kindness and wisdom, and for that I am fortunate. Thank you to my friends for your encouragement. And I am very blessed to have a beautiful woman who loves me so well - thank you, Eliza. I am so grateful for the multitude of wonderful blessings in my life. Thank you, GOD. 


\section{CONTENTS}

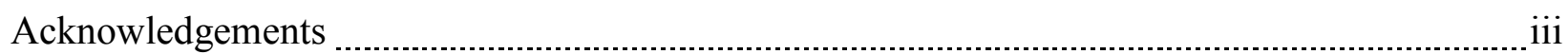

Chapter 1:

Introduction

Chapter 2:

The 1967 Arab-Israeli War: Soviet Policy by Other Means?

Chapter 3:

Phantom Peace: Henry “Scoop” Jackson, J. William Fulbright, and Military Sales to Israel 58

Chapter 4:

Stepping Forward: Nixon, Kissinger, and Step-By-Step-Diplomacy . 104

Chapter 5:

Walking Out of Step: Ford, Kissinger, and Step-By-Step Diplomacy 160

Chapter 6:

The Spirit of the 76: The Israeli Embassy and President Ford's Reassessment 195

Chapter 7:

Sinai II and the Executive Agreements Review Act of 1975

Chapter 8:

Conclusion 265

Bibliography 274 


\section{Chapter 1: \\ Introduction}

The United States experienced a significant shift around the end of the 1960s that profoundly affected United States foreign and domestic politics. The Cold War consensus between American liberals and conservatives, based on a bipartisan commitment to contain and defeat communism, started to crack with the worsening Vietnam War. Divisions emerged between and amongst Democrats and Republicans about how best to contain communism, the use of U.S. troops abroad, and relations with the Soviet Union. Divisions also emerged over New Deal-era legislation and liberal support for a range of social issues in the 1960s and 1970s, such as civil rights, abortion, women's rights, and gay rights. This produced a conservative backlash from the business community, evangelical Christians, and disaffected Democrats who had been alienated by the Vietnam War and liberal social legislation. The 1970s would be even less kind to American liberals as the economy worsened. The postwar economic boom came to an end, which led to a worldwide recession in the 1970s. The abandoning of the Bretton Woods system of fixed exchange rates and the oil crisis in 1973 also furthered the slide. Moreover, competition from the rebuilt economies of Europe and Japan, along with the concomitant rise of unemployment and inflation, undermined the Keynesian economic model that was central to American liberalism. The New Deal coalition, which included labor unions, minorities, farmers, people needing relief, and even many southern Democrats, fell apart and a New Right came to prominence in the mid-1970s, manifested especially in the 1980 presidential election of Ronald Reagan.

The changing political realities allowed for a crucial reworking of the "special relationship" between the United States and Israel, which would continue to impact U.S.-Middle East relations for decades. The special relationship amounts to being a durable, powerful 
informal alliance, marked by both conflict and consensus between the U.S. and Israel, which gradually developed during the early years of the Cold War and ramped up during the 1970s due to congressional assertiveness. Beginning with Harry Truman, U.S. Presidents attempted to walk a fine line by supporting Israel, but not alienating Arab states. Presidents continually declined to sell arms to Israel, and primarily because of the Cold War, sought to avoid being seen as proIsrael in Middle East policies. Eisenhower, in particular, pursued a more balanced, or "evenhanded" position that favored neither Israel nor Arab states, but instead viewed the region through the prism of the Cold War.

Slowly, U.S. Presidents agreed to sell weapons to Israel. Near the end of his presidency, Eisenhower agreed to sell radar equipment, though he declined to sell HAWK antiaircraft missile systems, which Israel really wanted. ${ }^{1}$ A few years later, John F. Kennedy approved the sale of eight HAWK systems to Israel, but he declined to sell offensive weapons. Lyndon Johnson agreed to sell 210 M-48 tanks and eventually offered 48 A-4 Skyhawk jets in March 1966. But Johnson was reluctant to sell Israel the more sophisticated F-4 Phantom jets - a significant upgrade from the Skyhawks that could tilt the military balance of power even further in Israel's direction. ${ }^{2} \mathrm{He}$ finally agreed to sell Phantoms at the end of his presidency, but that decision came in response to the Soviet Union's invasion of Czechoslovakia and vocal opposition from Congress. Johnson's decision to sell Phantoms in response to the USSR's aggressiveness in Europe and congressional demands to support Israel foreshadowed Nixon's confrontations with the Soviets in Egypt and Congress's insistence on more Phantom sales to Israel. Johnson refused

\footnotetext{
${ }^{1}$ The acronym HAWK stands for, Homing All the Way Killer.

${ }^{2}$ For the best treatment of Johnson's decision to sell the Phantom jets to Israel, see Mitchell Bard, The Water's Edge and Beyond: Defining the Limits to Domestic Influence on United States Middle East Policy (New Brunswick: Transaction Publishers, 1991), pp. 189-211. See also, Douglas Little, American Orientalism: The United States and the Middle East since 1945, Third Edition (Chapel Hill: The University of North Carolina Press, 2008), 93-103.
} 
to sell Phantoms to Israel for some time, just like Nixon would do. But both Presidents faced an increasingly active Congress that worked hard to secure weapons sales to Israel.

After a number of years of Congress ceding power to the President in the realm of foreign affairs, the Vietnam War emboldened the United States Congress to play a more active role in foreign policy. The U.S. Constitution explicitly protects the President's right to conduct U.S. foreign relations; however Congress, which maintains the "power of the purse," must formally approve any treaties and has the power to declare war. Following World War II, the legislative branch deferred to the "Imperial Presidency" in order to give the executive branch enough power and flexibility to fight the Cold War. ${ }^{3}$ The dynamic of the Imperial Presidency - with a powerful and assertive executive branch and an acquiescent legislative branch - came undone with the Vietnam War. As student protests and popular dissatisfaction with the war steadily increased, legislators felt obligated to intervene. Congress repealed the Tonkin Gulf Resolution in 1970, eventually cut off all funding to end the Vietnam War, and also passed legislation to restrict executive power in foreign affairs, such as the 1973 War Powers Act. ${ }^{4}$

The United States Congress and domestic politics played a crucial role in reshaping the U.S.-Israel special relationship during the presidencies of Richard Nixon and Gerald Ford. Leading into Nixon's presidency, U.S. military and political support for Israel had been modest. While Johnson certainly advanced the special relationship by selling, for the first time, tanks and aircraft, it was during the Nixon and Ford years that the U.S.-Israel relationship grew to unprecedented levels of political and military support. By the time of the Sinai II disengagement agreement between Israel and Egypt in 1975, the U.S. and Israel had cemented the special

\footnotetext{
${ }^{3}$ Arthur M. Schlesinger, Jr., The Imperial Presidency (Boston: Houghton Mifflin Company, 1973.

${ }^{4}$ The War Powers Act requires the President to secure congressional approval of American military forces deployed abroad after a period of 60 days.
} 
relationship with billion dollar aid packages and staunch political support from the U.S. for Israel in the international arena.

When Nixon took office in 1969, however, the future of U.S.-Israel relations remained uncertain. The Republican Nixon was a noted anti-communist and not known for being as sympathetic to the Israeli position as the many in the Democratic Party. While Democrats Truman, Kennedy, and Johnson all maintained generally positive relations with Israel, Eisenhower did not. As the former Vice President of Eisenhower, Nixon did not actually aim for a close relationship with Israel, a position that can also be gleaned from Nixon's anti-Semitic comments recorded on Oval Office tapes, and his many outbursts about Israel during the course of his two terms. While Nixon regarded Israel as an important friend in the Cold War, and he admired Israeli toughness, he actually sought an evenhanded position in the Middle East. But the U.S. Congress and domestic politics, along with Nixon's own weakened position due to Watergate and Vietnam, reworked Nixon's policy aims in the Middle East.

Many important works of scholarship have been written about U.S.-Israel relations and U.S.-Middle East foreign policy during this time period. Some of the first works were written by former political officials who played a role in U.S. relations with the region. William Quandt, who served on the National Security Council for Presidents Nixon and Carter and actively participated in the Camp David negotiations, has written the most useful overview of U.S. involvement in the Arab-Israeli conflict. Quandt originally published Decades of Decision in 1977, and then significantly revised that effort into Peace Process, which debuted in 1993 and the most recent, third edition was published in $2005 .^{5}$ Seth Tillman, who served as a member of the professional staff for the Senate Foreign Relations Committee from 1970 to 1976, argues that

\footnotetext{
${ }^{5}$ William B. Quandt, Decades of Decision: American Policy Towards the Arab-Israeli Conflict, 1967-1976 (Berkeley: University of California Press, 1977); William B. Quandt, Peace Process: American Diplomacy and the Arab-Israeli Conflict Since 1967, Third Edition (Washington D.C.: Brookings Institution, 2005).
} 
U.S. domestic politics - and especially the powerful pro-Israel lobby - undermined successive presidential administrations that aimed to resolve the Arab-Israeli conflict. According to Tillman, "what it comes down to, in concrete terms, is that, owing to the unmatched influence of the Israel lobby in American politics, Israeli security ... has been permitted to preempt other vital interests in American policy." ${ }^{6}$ Harold Saunders, longtime White House expert on Middle East politics and diplomacy, emphasizes the important symbiosis between the executive and legislative branches in formulating U.S. foreign policy in the region. Saunders also co-authored a piece about the mediation of the Sinai II agreement. ${ }^{7}$ Henry Kissinger, National Security Advisor and Secretary of State for both Nixon and Ford, released his memoirs in three separate volumes that at times discuss U.S. involvement in the peace process, as did Presidents Nixon and Ford. ${ }^{8}$

Scholars without access to closed-door, high-ranking conversations and documents must rely on declassified material. As more material has opened up, and classified documents have been pried open through FOIA (Freedom of Information Act) requests, more important works of scholarship have followed. Using primary sources collected from the presidential libraries of Dwight Eisenhower and Harry Truman, as well as research from the Israeli National Archives, historian Peter Hahn argues that by 1961, Cold War priorities had left the U.S., in the words of Hahn, "caught in the Middle East." "Warren Bass uses Kennedy's personal papers in his work,

\footnotetext{
${ }^{6}$ Seth P. Tillman, The United States in the Middle East: Interests and Obstacles (Bloomington: Indiana University Press, 1982), 276. It is worth noting that Tillman worked closely with Senator J. William Fulbright, known for his denunciations of the pro-Israel lobby, and Fulbright wrote the "Foreword" for the book.

${ }^{7}$ Harold H. Saunders, "The Middle East, 1973-1984: Hidden Agendas," in The President, the Congress, and Foreign Policy: A Joint Policy Project of the Association of Former Members of Congress and the Atlantic Council of the United States, eds., Edmund S. Muskie, Kenneth Rush, and Kenneth W. Thompson (Lanham, MD: University Press of America, Inc., 1986), pp. 175-205; Cecilia Albin and Harold H. Saunders, Sinai II: The Politics of International Mediation (Johns Hopkins University, School of Advanced International Studies, 1991).

${ }^{8}$ Henry A. Kissinger, White House Years (Boston: Little, Brown and Company, 1979); Henry A. Kissinger, Years of Upheaval (New York: Simon \& Schuster, 1982); Henry A. Kissinger, Years of Renewal (New York: Simon \& Schuster, 1999); Richard M. Nixon, The Memoirs of Richard Nixon (New York: Grosset \& Dunlap, 1978); Gerald R. Ford, A Time to Heal: The Autobiography of Gerald R. Ford (New York: Harper \& Row, Publishers, 1979). ${ }^{9}$ Peter L. Hahn, Caught in the Middle East: U.S. Policy toward the Arab-Israeli Conflict, 1945-1961 (Chapel Hill: The University of North Carolina Press, 2004).
} 
Support Any Friend, which details the Kennedy administration's handling of Middle East relations and the development of a U.S.-Israel alliance. ${ }^{10}$ While most works that examine the Johnson administration focus on the 1967 Arab-Israeli War, Robert David Johnson has offered an insightful treatment of Johnson's relationship with Israel based on his research of declassified secret Presidential tapes. ${ }^{11}$ Several works about the Nixon presidency have utilized declassified material, with one of the most recent and impressive being Craig Daigle's, The Limits of Détente. ${ }^{12}$ By comparison, little has been written about the Ford administration. ${ }^{13}$ Scholarship has emphasized presidential policies and downplayed congressional influence on U.S.-Middle East relations. Perhaps the three finest studies on the subject - Peace Process, by William Quandt, American Presidents and the Middle East, by George Lenczowski, and The Other Arab-Israeli Conflict, by Steven Spiegel - all use Cold War presidential administrations to structure their works. ${ }^{14}$ Quandt, like Kissinger, prefers a "realist" interpretation that often minimizes and sometimes dismisses the importance of domestic forces. ${ }^{15}$ Without question, pursuit of the national interest and conceptions of power drive foreign policy

\footnotetext{
${ }^{10}$ Warren Bass, Support Any Friend: Kennedy's Middle East and the Making of the U.S.-Israel Alliance (Oxford: Oxford University Press, 2003).

${ }^{11}$ Robert David Johnson, Lyndon Johnson and Israel: The Secret Presidential Recordings (Tel Aviv, 2008). Two of the leading works on the war are Michael B. Oren, Six Days of War: June 1967 and the Making of the Modern Middle East (New York: Oxford University Press, 2002) and Richard Parker, The Politics of Miscalculation in the Middle East (Bloomington: Indiana University Press, 1993).

${ }^{12}$ Craig Daigle, The Limits of Détente: The United States, the Soviet Union, and the Arab-Israeli Conflict, 19691973 (New Haven: Yale University Press, 2012); Boaz Vanetik and Zaki Shalom, The Nixon Administration and the Middle East Peace Process, 1969-1973 (Chicago: Sussex Academic Press, 2013); Moshe Gat, In Search of a Peace Settlement: Egypt and Israel Between the War, 1967-1973 (New York: Palgrave Macmillan, 2012).

${ }^{13}$ Yanek Mieczkowski, Gerald Ford and the Challenges of the 1970s (Lexington: The University Press of Kentucky, 2005); Salim Yaqub, "The Weight of Conquest: Henry Kissinger and the Arab-Israeli Conflict," in Nixon in the World: American Foreign Relations, 1969-1977 ed. Fredrik Logevall and Andrew Preston (New York: Oxford University Press, 2008), 227-248; and Galen Jackson, “The Showdown That Wasn't: U.S.-Israeli Relations and American Domestic Politics, 1973-1975," International Security 39, no. 4, (Spring 2015), 130-169. ${ }^{14}$ Quandt, Peace Process; George Lenczowski, American Presidents and the Middle East (Durham: Duke University Press, 1990); and Steven L. Spiegel, The Other Arab-Israeli Conflict: Making America's Middle East Policy, from Truman to Reagan (Chicago: The University of Chicago Press, 1985). Michael Oren also speaks highly of these three works in Power, Faith, and Fantasy: America in the Middle East, 1776 to the Present (New York: W. W. Norton \& Company, 2007), 11.

${ }^{15}$ Realism in international relations refers to the pursuit of the national interest and stresses the importance of economic and military power, as opposed to idealism, which emphasizes the importance of international law.
} 
considerations. Yet a democratic society's foreign policy also reflects popular involvement in the process. Elections, public opinion, as well as participation of the legislative body, which was designed by the Framers of the Constitution to broadly represent the collective interest of the people, require integration into the larger narrative. Spiegel, to a much greater extent than Quandt or Lenczowski, explores the impact of U.S. domestic forces on U.S. involvement in the Arab-Israeli conflict.

Scholars continue to debate the importance of domestic politics for the study of U.S. foreign relations. In his 2008 Presidential Address for the Society of Historians of American Foreign Relations (SHAFR), Thomas Schwartz argued that "the powerful impact of domestic politics is a constant in any attempt to explain the most significant decisions in American foreign relations, and neglecting domestic politics is likely to lead to a deficient understanding of why the United States acts as it does." ${ }^{16}$ Melvin Small has also written important works about domestic politics and U.S. foreign policy, most notably Democracy and Diplomacy, which explores the influence of domestic politics through the history of U.S. foreign relations. ${ }^{17}$ Small offers a more focused study about the importance domestic politics and the Vietnam War, At the Water's Edge. ${ }^{18}$ Schwartz points out that "even during the height of Cold War bipartisanship," many works have shown that "domestic politics still played an exceptionally significant role, in such decisions as the recognition of Israel, and many features of the Korean War, from the initial intervention to the rigid negotiating position on prisoners of war."19

\footnotetext{
${ }^{16}$ Thomas Alan Schwartz, "Henry, ... Winning an Election Is Terribly Important': Partisan Politics in the History of U.S. Foreign Relations," Diplomatic History, Vol. 33, Issue 2 (April 2009), 178.

${ }^{17}$ Melvin Small, Democracy and Diplomacy: The Impact of Domestic Politics on U.S. Foreign Policy, 1789-1994 (Baltimore: The Johns Hopkins University Press, 1996).

${ }^{18}$ Melvin Small, At the Water's Edge: American Politics and the Vietnam War (Chicago: Ivan R. Dee, 2005).

${ }^{19}$ Schwartz, 178.
} 
Domestic politics have taken on greater importance when U.S. foreign policy issues involve Israeli security. A well-organized lobby, particularly influential since the Johnson administration, along with strong public support for Israel has put presidential administrations in a consistently awkward spot. ${ }^{20}$ In many cases, administrations have sought a more balanced policy that favored neither Israelis nor Arabs, but powerful domestic forces challenged the extent of executive power in foreign policymaking in the Middle East. Consequently, presidential administrations often settled for Middle East policies that satisfied Cold War objectives, which usually meant preference given to Israel. The Sinai II agreement stands as just such an example.

Historians have largely overlooked Congress and U.S. foreign policy in the Middle East. Robert David Johnson avoids discussion of U.S.-Middle East relations in his outstanding study, Congress and the Cold War. According to Johnson, "Policy toward certain regions, especially the Middle East, largely fell outside of the Cold War framework because of the Arab-Israeli conflict, the role of oil diplomacy, the activities of the Israeli lobby, and the emergence of terrorism in the mid-1970s." ${ }^{21}$ Books by Mohamed Rabie and Marvin Feuerwerger have shed light on congressional influence on foreign aid packages for the Middle East, and specifically Israel. ${ }^{22}$ Other scholars have emphasized the importance of Congress in making U.S. foreign

\footnotetext{
${ }^{20}$ John J. Mearshimer and Stephen M. Walt, The Israel Lobby and U.S. Foreign Policy (New York: Farrar, Straus and Giroux, 2007). Mearshimer and Walt argue that the pro-Israel lobby, especially since the end of the Cold War, has been the most important factor influencing U.S.-Middle East policy. Though as noted above, Seth Tillman, William Fulbright, and others had been making that argument decades earlier. For other works critical of the proIsrael lobby, see George W. Ball and Douglas B. Ball, The Passionate Attachment: America's Involvement with Israel, 1947 to the Present (New York: Norton, 1992); Edward Tivnan, The Lobby: Jewish Political Power and American Foreign Policy (New York: Simon and Schuster, 1987); and Paul Findley, They Dare Speak Out: People and Institutions Confront Israel's Lobby (Westport, CT: Lawrence Hill, 1985).

${ }^{21}$ Robert David Johnson, Congress and the Cold War (Cambridge, NY, 2006), xxv.

${ }^{22}$ Marvin C. Feuerwerger, Congress and Israel: Foreign Aid Decision-Making in the House of Representatives, 1969-1976 (Westport, CT: Greenwood Press, 1979); Mohamed Rabie, The Politics of Foreign Aid: U.S. Foreign Assistance and Aid to Israel (New York: Praeger Publishers, 1988).
} 
policy, particularly in response the Vietnam War and a popular reaction against presidential mismanagement of foreign policy. ${ }^{23}$

My dissertation transforms the narrative in scholarship because it explores how domestic politics and congressional assertiveness reshaped U.S.-Israel relations during the Nixon and Ford presidencies. Therein, the Arab-Israel conflict and peace process take on special importance. Relying on a broad collection sources from presidential libraries, personal papers of former legislators, the Center for Legislative Archives at the U.S. National Archives, and the Israel State Archives, I argue that an embattled White House, due primarily to the fallout from Vietnam and Watergate, created a situation for Congress to play an unusually large role in U.S.-Middle East relations, which resulted in a fundamental shift in the special relationship. While Nixon and Ford continually pursued a balanced policy in the Middle East, an especially active Congress, reflecting strong public support for Israel, undermined presidential foreign policy. By the fall of 1975, after the Sinai II agreement and with civil war in Lebanon, the U.S. had committed itself to preserving its dominance in the Middle East at the expense of Palestinians and Syria in order to keep Israel powerful and Egypt out of the Soviet orbit. The natural result of policies enacted during the Nixon and Ford administrations was the Camp David Peace Agreement, which formalized peace between Israel and Egypt, but left Palestinian grievances unaddressed. Taking Egypt out of the war with Israel ensured decades of peace between the two countries, and further, the U.S. scored an important victory in the Cold War by permanently removing Egypt from the Soviet camp, a decision made by Egypt with some U.S. prodding. Yet U.S. foreign policy in the

\footnotetext{
${ }^{23}$ For works on Congress and foreign policy, see John Lehman, The Executive, Congress, and Foreign Policy: Studies of the Nixon Administration (New York: Praeger Publishers, 1974); Thomas M. Franck and Edward Weisband, Foreign Policy by Congress (Oxford: Oxford University Press, 1979); Edmund S. Muskie, Kenneth Rush, and Kenneth W. Thompson, eds., The President, the Congress, and Foreign Policy: A Joint Policy Project of the Association of Former Members of Congress and the Atlantic Council of the United States (Lanham, MD: University Press of America, Inc., 1986); Thomas E. Mann, ed., A Question of Balance: The President, the Congress, and Foreign Policy (Washington D.C.: The Brookings Institution, 1990); and John Spanier and Joseph Nogee, eds., Congress, the Presidency and American Foreign Policy (New York: Pergamon Press Inc., 1981).
} 
Middle East by no means followed a course preferred by successive presidential administrations. Congress, influenced by powerful lobbying groups, was an important player as well. Thus, domestic politics and Cold War realities, when taken together, offer a richer narrative about U.S.-Middle East politics and U.S.-Israel relations.

This dissertation analyzes U.S. foreign relations with Israel and involvement in the peace process during the Nixon and Ford administrations, and proceeds in the following fashion. At the end of this chapter, an extended background discusses U.S.-Israel relations since 1948, as well as U.S.-Middle East policies in the context of the Cold War. As Hahn points out, the United States and Israel did not enjoy a special relationship during the Truman and Eisenhower presidencies. In particular, "disagreements on security-related issues involving the Arab states generated friction and acrimony in the official relationship." ${ }^{24}$ The special relationship advanced under President Kennedy, who agreed to sell HAWK antiaircraft systems to Israel, as well as President Johnson, who went even further by selling powerful weaponry, like tanks and aircraft. Then, the outbreak of war in the Middle East in June 1967 reshaped the Arab-Israeli conflict, along with U.S. relations with the region. Arab nations desired a total Israeli withdrawal to the pre-1967 borders, which Israel continually rejected.

The second chapter focuses specifically on the 1967 Arab-Israeli war and frames the discussion by assessing the prevailing historiography about Soviet and U.S. foreign policy. Based on research collected at the Lyndon Johnson Presidential Library and documents from the Foreign Relations of the United States (FRUS), along with a review of the relevant literature, I argue that the Soviet Union was notably uninterested in taking measures to prevent war in the Middle East. Soviet officials continually stonewalled peace discussions inside and outside of the United Nations, while Soviet propaganda painted a picture of U.S.-Israeli collusion, thereby

\footnotetext{
${ }^{24}$ Hahn, 4.
} 
straining U.S. relations with Arab states and generally weakening the U.S. position in the region. In the aftermath of the war, the Johnson administration agreed to not force Israel out of the occupied territories until formal peace treaties were signed - a reversal of the Suez crisis in 1956-57. The U.S. position became encapsulated in U.N. Resolution 242, which established a land-for-peace formula, and became the basis for all peace negotiations moving forward.

The third chapter uses the conflict between two Democratic senators - Henry "Scoop" Jackson and J. William Fulbright - to show how the growing Soviet presence in the Middle East, combined with the deteriorating situation in Southeast Asia in the late 1960s and early 1970s, brought about a major conflict within the Democratic Party as well as a rise in conservative support for Israel from the halls of Congress. Before leaving office, President Johnson finally agreed to sell Phantom fighter jets to Israel, which significantly upgraded Israel's military weaponry and threatened to escalate the arms race in the region. However when President Nixon came into office, he sought a more balanced policy to prevent Arab states from getting closer to Moscow, while at the same time he pursued détente with the Soviet Union. Even after the USSR significantly upgraded its military presence in Egypt in early 1970, Nixon continually declined to sell more Phantoms to Israel. But by the end of 1971, Nixon finally relented and offered a generous weapons package to Israel that included the sought-after Phantom jets. The activities of the U.S. Congress, and especially conservative legislators, played an important role in this decision.

The fourth chapter explores the efforts of the Nixon administration to mediate the ArabIsraeli conflict after the 1973 Arab-Israeli war. After peace negotiations following the 1967 war led nowhere, Washington preferred to remain mostly aloof from further peace discussions. However the 1973 war - and especially the oil embargo instituted by the Organization of 
Petroleum Exporting Countries (OPEC) - forced the Nixon administration to play a more active role in facilitating a peace agreement. Henry Kissinger conceived of "step-by-step diplomacy" (a series of incremental agreements) as a way to defuse tensions in the region, shelter Israel from immediate calls for withdrawal, provide a situation for Israel to remove itself from the occupied territories (with minor adjustments), and allow for better U.S.-Arab relations. But the fall of Nixon, due to Watergate, sapped the power of the White House at precisely the moment that required a strong President to advance the most ambitious program of U.S. diplomacy in the Middle East up to that point, or after.

The fifth chapter explores the conflict between President (and former legislator) Gerald Ford and the U.S. Senate to show how the executive and legislative branches were "walking out of step" during the crucial period of step-by-step-diplomacy. After negotiations for a Sinai II agreement between Israel and Egypt fell apart during March 1975, Ford declared a "reassessment" of U.S.-Middle East foreign policy, which included an immediate freeze on all aid to the region. Ford was mad because he felt Israeli officials had intentionally misled Kissinger and himself about Israel's readiness to reach an agreement with Egypt. Both Ford and Kissinger were convinced that Israel was using step-by-step diplomacy as a means for avoiding, rather than advancing, peace discussions with its neighbors. The Ford administration thought that Israel had taken an unnecessarily hard line with Egypt in order to kill the momentum of step-bystep diplomacy and undermine the developing relations between the U.S. and the Arab world. Thus, Ford responded with reassessment to pressure Israel to walk-in-step with U.S. diplomatic efforts. But a powerful, pro-military assistance letter from the U.S. Senate - which called for an immediate resumption of aid to Israel and signed by 76 senators - significantly undermined Ford's foreign policy maneuver and left the administration with little choice but to pay a heavy 
price to get Israel to agree to another partial step towards peace with Egypt in September 1975. Without that agreement the Ford administration believed another war - and oil embargo - were imminent.

The sixth chapter discusses how the Israel embassy in Washington D.C. worked to divide the executive and legislative branches, and otherwise exert pressure on U.S. officials in order to influence U.S. foreign policy. Using research collected at the Israel State Archives, I argue that Israeli Ambassador Simcha Dinitz played an enormous role in shaping the attitudes of highranking U.S. officials during the main period of reassessment, between late March and late May 1975. Dinitz, for example, first floated the idea of the Senate letter in support of the Israeli position, which eventually gained signatures from 76 senators (mentioned above). Referred to by some Israeli officials as "the spirit of the 76," the Senate letter - with its origins in a foreign embassy - remains the strongest congressional challenge to presidential policy in the Middle East.

The seventh chapter, which closes the main portion of the dissertation, explores congressional efforts to rein in the use of executive agreements. While a treaty requires ratification by the Senate, an executive agreement does not; in short, it allows the executive branch to conduct foreign policy without consultation with Congress. Although executive agreements date back to as early as the late eighteenth century, the use of executive agreements started to rise with Franklin Roosevelt, and then took on even greater importance with the Cold War as presidential administrations argued for greater autonomy from legislative involvement in fighting the Cold War. But executive mismanagement of foreign policy led to the Vietnam War, and Congress was particularly irritated by Nixon's convenient usage of executive privilege. Efforts to curb the use of executive agreements came to a head during Ford's presidency with the 
Executive Agreements Review Act of 1975. Although Congress proved unable to pass legislation to restrict the use of all executive agreements, it challenged the Ford administration over the controversial executive agreements connected to Sinai II concluded in September 1975. In order to make the agreement acceptable to both sides, the U.S. entered into a series of executive agreements that signaled a new stage in U.S.-Israel relations. Interestingly, the congressional challenge to the executive branch had less to do with U.S.-Middle East foreign policy and more to do with power relations between the branches, showing another way that domestic politics impact U.S. foreign relations.

The final chapter, which concludes the dissertation, recaps the pivotal role played by Congress and domestic politics in the reworking of the U.S.-Israel special relationship. The Vietnam War opened the door for greater congressional participation in U.S. foreign policy. As President Nixon's position became as untenable as Saigon's, Congress advanced a powerful proIsrael position that was actually more in line with U.S. popular opinion at this time than the White House's insistence on an evenhanded regional policy. Strengthened by the relative decline of power in the executive branch, the U.S. Congress used weapons sales and strong bipartisan support for Israel to redefine the special relationship and demonstrate that the legislative branch plays an important role in U.S. foreign relations.

\section{Background}

The Arab-Israeli conflict, which has its roots in European colonialism, nationalism, and great power conflict, took on a new meaning with the 1948-49 Arab-Israeli war. The diplomatic and territorial confusion of the first half of the twentieth century, due in large part to the dissolution of the Ottoman Empire, was replaced by a dramatically altered status quo. Large- 
scale Jewish migration to Palestine followed the horrors of the Holocaust, and Israel transitioned from demanding its own state to protecting its own state. Arab Palestinians, pushed out by Israel, were left without a state. Further, Arab states refused to recognize the legitimacy of the state of Israel, and the Arab League imposed an economic and diplomatic embargo on the Jewish state shortly after the war. ${ }^{25}$ But basically, the conflict boiled down to two issues - the status of Palestinian refugees and the unwillingness of Arab states to recognize the state of Israel. Until June 1967, these two issues would form the core of the Arab-Israeli conflict.

The war between Jews and Arabs in Palestine was one of great success for Jews, and great sorrow for Arab Palestinians. The victors refer to the "War of Independence," while the displaced and defeated recall the nakba, or "catastrophe."

The war had two phases. During the first phase, which lasted from December 1947 through May 1948, a civil war was fought between the Yishuv and Palestinians. ${ }^{26}$ On May 14, 1948, Ben-Gurion, who at the time was the head of the World Zionist Organization, declared Israel an independent state. The following day, the war entered its second stage as Arab states invaded Palestine to crush the infant Jewish state. But Arab states lacked cohesion. The Arab League, created in 1945 and originally included Saudi Arabia, Iraq, Syria, Lebanon, Egypt, and Jordan, was divided into two camps - Iraq and Jordan were ruled by the Hashemite family, while Egypt, Syria, and Saudi Arabia banded together, fearing a Hashemite conspiracy due to its close relations with Britain. ${ }^{27}$ Consequently, Arab armies were never able to muster a sufficient, effective fighting force. Jordan in particular proved unwilling to attack Israel. As early as 1921, King 'Abdullah of Jordan had been meeting with Yishuv leadership about a Greater Syria that

\footnotetext{
${ }^{25}$ The Arab League, at that time, included Egypt, Iraq, Jordan, Syria, Lebanon, Saudi Arabia, and Yemen.

${ }^{26}$ The Yishuv refers to Jewish society prior to the establishment of the State of Israel.

${ }^{27}$ James L. Gelvin, The Israel-Palestine Conflict: One Hundred Years of War, Second Edition (Cambridge:

Cambridge University Press, 2007), 130.
} 
included Syria, Lebanon, and Palestine. Since 'Abdullah and the Zionist leadership had already staked out their territorial claims, very little fighting occurred between Jordanians and Israelis. ${ }^{28}$ Although outnumbered, the Israelis used superior organization to fend off Arab attackers and negotiated armistice agreements with Egypt, Syria, Lebanon, and Jordan during the first six months of $1949 .{ }^{29}$ But the armistice agreements were not peace agreements, and Arab states reserved the right to renew hostilities at any point. ${ }^{30}$

The Palestinian refugee problem began with the 1948-49 Arab-Israeli war, as Arab Palestinians fled their homes due to fighting or Israeli occupation. Overall, about 720,000 Palestinians became refugees - approximately one-half of the Arab Palestinian population before the war. ${ }^{31}$ Arab states argued for repatriation, or the "right of return." But Israelis argued for resettlement. To Zionists, there was no such thing as an independent Palestinian state and, hence, no such thing as a Palestinian nation. Thus, according to this logic, those displaced by the war could be resettled in Arab lands because the refugees were simply Arabs anyway. ${ }^{32}$ And before Israeli officials would consider the refugee problem, they demanded that Arab states agree to full peace, meaning recognition of the State of Israel and normal diplomatic relations, to replace the armistice agreements.

The war resulted in a redrawing of the artificial borders in Palestine. The state of Israel comprised most of the former territory of Palestine, while Jordan annexed the West Bank of the Jordan River and Egypt controlled the Gaza Strip; the holy city of Jerusalem was divided between Israel and Jordan, with the "new city" administered by Israel and the "old city" by

\footnotetext{
${ }^{28}$ Zionists were Jewish nationalists who supported the establishment of a Jewish homeland within the historical boundaries of the Land of Israel.

${ }^{29}$ Gelvin, 126.

${ }^{30}$ Michael Oren, Six Days of War: June 1967 and the Making of the Modern Middle East (Oxford: Oxford University Press, 2002), 6.

${ }^{31}$ Gelvin, 135 .

${ }^{32}$ Ibid., 132.
} 
Jordan. ${ }^{33}$ Many Palestinian refugees fled to the West Bank or Gaza Strip, while some resettled in Arab states, and others became internal refugees within Israel. A Palestinian state ceased to exist. As the regional situation in the Middle East evolved into a new status quo, so too did the international situation. The United States and Soviet Union emerged from the carnage of WWII as global superpowers, and the ensuing tension between these superpowers, largely due to ideological conflict that included differing ideas about the proper economic model, would be called the Cold War. With plentiful oil fields and a region that bordered Europe, Asia, and Africa, the Middle East war regarded as a vital region of interest by both superpowers, and each sought to expand their influence.

Israel's rise to prominence, the Arab-Israeli conflict, a significantly reduced presence of British and French forces due to the end of the mandate system, and the onset of the Cold War required a redefinition of American interests in the Middle East. Before the Cold War, the U.S. was not that concerned with Middle East affairs. Following WWI and the dissolution of the Ottoman Empire, European colonial powers Britain and France received "mandates" from the League of Nations to administer newly created nation-states in the region and maintain stability. ${ }^{34}$ Washington certainly opposed the colonial empires of Europe, and some Americans were drawn to the Middle East for religious and commercial reasons. But the discovery of large supplies of oil in the Arab Middle East and the fear of communism convinced Washington to play a more active role in the region. Moreover, in the aftermath of the Holocaust many Americans felt a cultural attachment to the plight of the Jewish people and supported the creation of the state of Israel. As Michelle Mart points out in her book, Eye on Israel, after the Holocaust many Americans changed their anti-Semitic feelings and began viewing Jews in a more positive

\footnotetext{
${ }^{33}$ Ibid., 133-134.

${ }^{34}$ Through the mandate system, Britain administered Palestine, Transjordan, and Iraq, while France administered Lebanon and Syria.
} 
light. Americans began seeing cultural similarities, rather than differences, and even came to admire Israel for its accomplishments, which contributed to a popular acceptance of Israel as an ally. Mart shows that popular culture impacted public opinion, as Israelis were depicted as masculine and tough, much different from the stereotype of Jews being a weak victim. Israel was seen as a "gutsy underdog" against the Arab states, much like David versus Goliath. ${ }^{35}$ Importantly, Mart's book forces one to consider the cultural and intellectual side to U.S.-Israeli relations, rather than simply a political-strategic relationship.

The Harry Truman administration was divided on whether or not to recognize the state of Israel. The State Department hoped for a balanced policy that favored neither Israel nor Arab states. But Truman's pro-Zionist domestic advisers warned the President that the loss of the Jewish vote in Illinois and New York could potentially cost Truman the election in 1948. Additionally, they stressed an American moral commitment to the Jewish people after the Holocaust. ${ }^{36}$ Ultimately, Truman's advisers carried the day. After David Ben-Gurion declared Israel an independent state on May 15, 1948, Truman followed with official American recognition within just 11 minutes. $^{37}$

Yet Truman was not decidedly pro-Zionist. He angered Israeli leaders and some members of Congress by rejecting Israeli military aid requests, insisting on the importance of the Palestinian refugee situation, and refusing to move the U.S. embassy from Tel Aviv to Jerusalem to keep from upsetting Arab states. Israel responded with a public relations onslaught called a hasbara. Peter Hahn, one of the leading historians of American involvement in the Arab-Israeli

\footnotetext{
${ }^{35}$ Michelle Mart, Eye on Israel: How America Came to View Israel as an Ally (Albany: State University of New York Press, 2006), 67.

${ }^{36}$ Gelvin, 125.

${ }^{37}$ Peter Hahn, Caught in the Middle East: U.S. Policy toward the Arab-Israeli Conflict, 1945-1961 (Chapel Hill: The University of North Carolina Press), 50. Like Gelvin, Hahn also discusses the conflict between the State Department and Truman's advisers (49-50).
} 
conflict and one of the first U.S. diplomatic historians to use documents from Israeli archives, shows that Israel secretly coordinated a campaign to increase congressional and media pressure on the White House to be responsive to Israeli requests. At times, this only angered Truman and more firmly entrenched his posture towards Israel. But at other times, domestic considerations persuaded Truman to be sympathetic to Israeli requests, such as in April 1950 when Truman broke with the Pentagon and State Department and ordered State to resupply Israel to the point of satisfying the "many active sympathizers with Israel in this country." "38

Israeli officials consciously sought to cultivate stronger relations with the American Congress and public opinion. For example, in 1949 Israeli ambassador Eliahu Elath hosted a dinner for various Jewish members of Congress, like Jacob Javits (R-New York) and Abraham Ribicoff (D-Connecticut), who Israeli leaders hoped would advance the Israeli position. ${ }^{39}$ When Senator Theodore Green (D-Rhode Island) criticized Israel in April 1952, Israeli ambassador Abba Eban arranged a "flood of protests from Rhode Island." 40 In trying to rally public opinion, hasbara chief Abraham Harman claimed to have influence over American newspapers, film and television productions, U.S. Christians, and also maintained close ties with labor leaders and American universities. $^{41}$

Neither the Truman nor the Eisenhower administrations were able to facilitate a satisfactory resolution to the Arab-Israeli conflict. During the 1948-49 war, the Truman administration supported a permanent settlement advanced by the Swedish diplomat Folke Bernadotte, who the U.N. Security Council selected to mediate the Arab-Israeli conflict. The Bernadotte Plan proposed that Arab states recognize Israel, Jordan annex parts of Palestine not

\footnotetext{
${ }^{38}$ Quoted in Hahn, 74.

${ }^{39}$ Ibid., 134.

${ }^{40}$ Quoted in Hahn, 135.

${ }^{41}$ Ibid., 135.
} 
taken by Israel, Israel repatriate Palestinian refugees, and international control of Jerusalem. After being rejected by both sides, Israeli extremists assassinated Bernadotte in Jerusalem. ${ }^{42}$

The popularity of the Bernadotte Plan soared after the assassination, and became an issue in the 1948 presidential election. The Republican and Democratic parties developed a "bipartisan consensus" in support of the plan, and importantly, Secretary of State George Marshall backed it as well. In response, Truman's political advisers and Israeli officials worked hard to break the consensus by stressing the importance of the upcoming election and cultivating mistrust between the President and the State Department. "Under Israeli and U.S. Jewish pressure," writes Peter Hahn, "the bipartisan consensus finally collapsed in mid-October." The Bernadotte Plan, lacking support from any parties to the conflict and no longer an issue in U.S. domestic politics, was taken off the table by the U.N. in late $1948 .^{43}$

The Truman administration tried again to find a solution to the conflict by promoting bilateral agreements between Israel and its neighbors in 1949 and 1950. But here again, the Administration found little support on either side for such measures. ${ }^{44}$ Eisenhower tried to achieve a peace settlement with the Alpha peace plan in 1955, which involved a combination of Israeli repatriation of Palestinian refugees, along with Arab states absorbing some 800,000 refugees, as well as other considerations. ${ }^{45}$ But Israel and Arab states balked at the proposal, and combined with increasing hostilities between Israel and its neighbors, the Alpha plan fell apart.

Frustrated by an inability to resolve the Arab-Israeli conflict, American officials aimed primarily to protect oil supplies and thwart communist advances. The availability of oil in the Middle East was crucial for rebuilding war-torn Western Europe and Japan, while denying oil to

\footnotetext{
${ }^{42}$ Ibid., 54-55.

${ }^{43}$ Ibib., 57-59.

${ }^{44}$ Ibid., $90-91$.

${ }^{45}$ Ibid., 184.
} 
the Soviet Union was nearly equally important. Consequently, Washington and London devised a plan to defend the Northern Tier states (Iran, Iraq, Turkey, and Pakistan) from possible Soviet aggression and thereby secure oil reserves. This became the Baghdad Pact, which formed in 1955. While American officials supported the British decision to join the alliance, the U.S. never officially became part of the Baghdad Pact in order to avoid Soviet retaliation, Egyptian criticism, and Israeli demands for a similar defense treaty. ${ }^{46}$ Nevertheless, the U.S. remained unofficially involved. ${ }^{47}$ The alliance, which never gathered consistent Arab or American support, eventually dissolved in 1979 after Iran withdrew during its revolution.

Beyond the Northern Tier, Saudi Arabia and its oil were also crucial to American interests in the region. By 1949 the Arabian-American Oil Company was producing 550,000 barrels of oil per day. ${ }^{48}$ But American-Saudi relations were complicated by the role of Britain in the region. Britain had enjoyed close relations with Ibn Saud, the leader of the Kingdom of Saudi Arabia, and also maintained the Aden Protectorate in southern Arabia. Further, Britain planned to use Middle Eastern oil to fuel its navy, and after WWII hoped oil profits would bolster the pound sterling, which had become devalued in relation to the dollar. Thus, while AngloAmerican relations became crucial for maintaining a Western alliance against the communist threat, pursuit of oil profits in Saudi Arabia actually strained Anglo-American relations. As Nathan Citino argues, London and Washington employed different strategies for advancing their own national interests in Saudi Arabia. American officials used private companies to gain access to oil reserves and conduct informal diplomacy by developing closer relations with the Saudi government. By contrast, Britain used collusion and military power to defend its economic

\footnotetext{
${ }^{46}$ Ibid., 152.

${ }^{47}$ Ibid., 153-154.

${ }^{48}$ Ibid., 23.
} 
interests, similar to colonial-style imperialism. ${ }^{49}$ The American model proved to be more successful as "an informal American empire gradually replaced a more formal British one." ${ }^{\circ 0}$ American policymakers continually employed a careful balancing act of maintaining close relations with a colonial power while not becoming associated with colonialism in the minds of Middle Easterners.

Perhaps most important, American officials sought to maintain stability and promote proU.S. governments in the Middle East. American policymakers believed that instability would provide fertile breeding grounds for communism. Yet during the 1950s, the Middle East experienced seemingly unending political upheaval. During 1949, Husni Za'im of Syria was overthrown and executed after less than six months of being in power. In July 1951, 'Abdallah of Jordan was assassinated by a Palestinian in Jerusalem. King Faisal of Iraq was dismembered by a mob in Baghdad in 1958; following his violent dismissal from power, Iraq removed itself from the Baghdad Pact. The CIA played a key role in ousting Iranian President Mossadeq from power after he nationalized the Anglo-Iranian Oil Company. Mossadeq was replaced by the Shah in August 1953, and until he was deposed during the Iranian Revolution 25 years later, the Shah enjoyed a close relationship with the United States.

The regime change that had the biggest impact happened in Egypt in July 1952, when King Faruq of Egypt was ousted by a military coup that eventually brought Gamal Abdel Nasser to power. Nasser quickly became the leading political figure in the Middle East. He declared Egypt an Arab country and pursued a "nonaligned" course - meaning that he sided with neither the U.S. nor the USSR in the Cold War (although he was happy to get military and economic aid from either side, whenever possible). He also developed "Nasserism," a political movement that

\footnotetext{
${ }^{49}$ Nathan J. Citino, From Arab Nationalism to OPEC: Eisenhower, King Sa'ud, and the Making of U.S.-Saudi Relations (Bloomington: Indiana University Press, 2002), 110.

${ }^{50}$ Ibid., 17.
} 
sought to blend Arab nationalism with socialism as a means for creating an Arab world that could ward off the influences of either superpower. Nasser opposed the Baghdad Pact because he believed it undermined Arab solidarity by dividing up the Arab world. More distressing to Washington, Nasser grew increasingly close to the Soviet Union. In 1955, Nasser purchased an extraordinary amount of Soviet arms and munitions - more tanks, guns, and jets than all other Middle East countries combined. ${ }^{51}$

Egyptian relations with the West hit a low point in 1956 with the Suez crisis. Angered by Nasser's close relationship with the USSR, London and Washington pulled their funding offer for the Aswan Dam. In response, Nasser nationalized the British- and French-owned Suez Canal Company in July 1956. By declaring Egyptian control of the canal, Nasser could both demonstrate his independence from outside powers and reap the financial rewards of the canal. But Britain and France threatened a forceful retaking of the canal, if necessary, and found a willing ally in Israel. France and Israel enjoyed a close relationship primarily because France was embroiled in a vicious war in Algeria; Nasser supported the Algerian nationalist movement, which moved France closer to Israel. France remained the primary supplier of arms to Israel until the 1967 Arab-Israeli war, although U.S. involvement at times helped facilitate arms transfers. ${ }^{52}$ And France actually worked with Israel to construct a nuclear facility in Dimona in that later part of the $1950 \mathrm{~s} .{ }^{53}$

The Suez crisis soon became the second Arab-Israeli war. In October 1956, a coordinated British-French-Israeli invasion of Egypt was successful as the invading forces occupied the

\footnotetext{
${ }^{51}$ Ibid., 9.

${ }^{52}$ Hahn, 189-190. According to Hahn, Eisenhower refused Israeli arms request in the spring of 1956, but hinted that France and Canada would be willing to supply Israel. But as Hahn points out, Eisenhower was influenced by the upcoming 1956 election, as well as a petition from more than 150 members of the House of Representatives who recommended selling Israel arms totaling more than $\$ 50$ million.

${ }^{53}$ Michael B. Oren, Six Days of War: June 1967 and the Making of the Modern Middle East (New York: Oxford University Press, 2002), 13.
} 
Canal Zone, Sinai Peninsula, and Gaza Strip. Although Eisenhower cared very little for Nasser, he liked European colonialism even less. Further, the invasion was a violation of the Tripartite Agreement from 1950, signed by Britain, France, and the U.S., which declared that territory could not be taken by force in the Middle East. Eisenhower sought an "evenhanded" policy - one that would not alienate Arab states by favoring Israel - and he publicly rebuked the invasion. After Eisenhower warned that the U.S. would stop supporting the British pound, along with the threat of Soviet intervention, the invading powers left Egypt. The 1956 war weakened the Western alliance of the U.S., Britain, and France, and the power-play by Eisenhower signaled a changing-of-the-guard in the Middle East as the United States replaced Britain and France as the most dominant outside power in the region.

The 1956 war rekindled the Arab-Israeli conflict. While the Suez crisis could have led to a new status quo that allowed for a peace initiative, unfortunately, the parties to the conflict were still far apart. Similar to the aftermath of the 1948-49 war, armistice agreements were used instead of peace agreements, and the fundamental issues of the Arab-Israeli conflict persisted as Palestinian refugees remained stateless and Arab states refused to recognize Israel.

The 1956 war strained relations between the United States and Israel. Like most other Republicans, Eisenhower did not enjoy electoral support from the American Jewish community. He and Secretary of State John Foster Dulles wanted to adhere to a more balanced foreign policy in the Middle East in order to prevent Arab states from being pushed into the communist camp. ${ }^{54}$ Naturally, Eisenhower's commitment to impartiality concerned Israeli leaders, which brought reaction from hasbara officials who continually tried to mobilize congressional support and public opinion in Israel's favor. But Eisenhower, more than Truman, stood his ground. And in 1958, Eisenhower nearly sided with the Pentagon, which "advised that the United States break

\footnotetext{
${ }^{54}$ Hahn, 155.
} 
all ties with Israel to preserve the waning American influence among Arab powers. Although he ultimately decided not to pull the plug on U.S.-Israeli relations, the president did not express deep admiration for Israel or its friendship." 55

While Eisenhower aimed for a more balanced policy in the Middle East, his primary goal was to prevent Arab states from aligning with the Soviet Union. To that end, the President declared the "Eisenhower Doctrine" in early 1957, which pledged military and economic support to help Middle East countries defend against international communism. ${ }^{56}$ But as Salim Yaqub argues, Eisenhower also tried to suppress Arab nationalism, which he believed was only a small step away from communism. He took specific aim at "the radical Arab nationalism" of Nasser, and "to discredit his policy of "positive neutrality" in the Cold War." further calibrated his own evenhanded policy by not extending too much goodwill to Nasser, who he regarded as a potential danger to American interests. As Peter Hahn points out, American policymakers consistently sought to undermine Arab nationalism and support conservative regimes in the Middle East, like Iran and Saudi Arabia, during the Cold War. ${ }^{58}$

At first, Eisenhower established a more evenhanded policy in the Middle East argues historian Douglas Little. But by the end of his Administration, the United States and Israel started to develop a "special relationship," or powerful informal alliance. ${ }^{59}$ Like Hahn, Little contends that following Truman's recognition of the state of Israel, U.S.-Israeli relations cooled

\footnotetext{
55 Ibid., 289.

56 Ibid., 224.

${ }^{57}$ Salim Yaqub, Containing Arab Nationalism: The Eisenhower Doctrine and the Middle East (Chapel Hill: The University of North Carolina Press, 2004), 2.

${ }^{58}$ Hahn, 4. William Stivers makes a similar argument in America's Confrontation with Revolutionary Change in the Middle East, 1948-1983 (New York: St. Martin's Press, 1986).

${ }^{59}$ Douglas Little, "The Making of a Special Relationship: The United States and Israel, 1957-68," International Journal of Middle East Studies, Vol. 25, No. 4 (November 1993), 563-585. In the first paragraph of his article, Little efficiently discusses some of the more influential writings on the topic and the nature of the historiographical arguments. Little expands on this article by stretching his study up to the presidency of George W. Bush in American Orientalism: The United States and the Middle East since 1945, Third Edition (Chapel Hill: The University of North Carolina Press, 2008), 77-115.
} 
during the 1950s and hit rock-bottom during the Suez crisis and its aftermath. But towards the end of the decade, a mutual desire to contain Arab nationalism and communism in the Middle East brought the two countries closer together. Little notes that the thaw in U.S.-Israeli relations had become evident by 1960 when Prime Minister David Ben-Gurion visited Washington to ask Eisenhower to sell HAWK antiaircraft missiles to Israel. Although Eisenhower was reluctant to begin selling the Israelis such advanced weaponry, he agreed to sell nearly $\$ 10$ million worth of sophisticated radar equipment, which signaled warmer relations between Washington and Tel Aviv. ${ }^{60}$

The special relationship advanced during John Kennedy's presidency. The support of Jewish voters in New York certainly helped Kennedy defeated Richard Nixon in the 1960 presidential election. ${ }^{61}$ When leaving office, Eisenhower cautioned Kennedy that Israel was developing the capability to create nuclear weapons at their reactor in Dimona, and in the spring of 1961, Kennedy learned that Israelis intended to buy medium-range French bombers that could deliver nuclear weapons. When Ben-Gurion pressed Kennedy to sell Israel "defensive weapons" like HAWK missile systems, Kennedy initially declined fearing an escalation of an arms race in the Middle East. But after receiving Israeli assurances that nuclear weapons would not be developed, Kennedy agreed to sell eight HAWK batteries to Israel in $1962 .^{62}$

While Kennedy strengthened the U.S.-Israeli relationship, he also sought rapprochement with Nasser. For Kennedy, a comprehensive settlement to the Arab-Israeli conflict would have to go through Cairo, which required better relations between the U.S. and Egypt. Kennedy

\footnotetext{
${ }^{60}$ American Orientalism, 94.

${ }^{61}$ For details on Kennedy's relationship with American Jews, see: Edward Tivnan, The Lobby: Jewish Political Power and American Foreign Policy (New York: Simon and Schuster, 1987), 52-56. Regarding the influence of the Jewish vote on presidential elections, Tivnan cites M.S. El Azhary, Political Cohesion of American Jews in American Politics (Lanham, MD: University Press of America, 1980). Tivnan claims El Azhary convincingly argues that after JFK's victory in the 1960 election, the Jewish vote did not significantly influence an election until Jimmy Carter defeated Gerald Ford in 1976.

${ }^{62}$ American Orientalism, 95.
} 
preferred the carrot to the stick in his dealings with Nasser. Using personal diplomacy and generous economic aid, Kennedy developed better relations with Egypt. However, those relations were undermined by Egypt's involvement in the brutal Yemeni civil war and Nasser's belligerent rhetoric directed at Israel. In the end, Kennedy needed more than goodwill and aid packages to resolve the Arab-Israeli conflict.

The Middle East continued to exhibit dangerous instability, which worked against any efforts to mediate peace agreements. In 1963, King Hussein of Jordan was nearly dethroned by West Bank Palestinians. During the same year, revolutions in Syria and Iraq ramped up the pressure on Israel. Nasser, who had seemed welcoming to Kennedy's overtures, rebuffed the president's attempts to stop the arms race in the Middle East. And the French-Israeli relationship had cooled after the end of the Algerian war and the French desire to mend fences with Arab states after Suez in $1956 .{ }^{63}$

Israeli officials lobbied Capitol Hill and the White House for more weaponry in light of recent events. Kennedy promised Ben-Gurion that American support for Israel would be ready in the event of an attack, but Israeli supporters wanted more, and convinced Senators Jacob Javits and Hubert Humphrey to propose "collective defensive arrangements with Israel." ${ }^{\prime 44}$ While such arrangements never came to be, the effort demonstrated that the special relationship between the U.S. and Israel was advancing.

After Kennedy's assassination, Lyndon Johnson cemented the special relationship between the United States and Israel. He told Golda Meir, "The United States will continue its warm friendship with Israel. Israel can count on this. ${ }^{95}$ Johnson also told an Israeli diplomat,

\footnotetext{
${ }^{63}$ Oren, 26.

${ }^{64}$ Quoted in American Orientalism, 96.

65 "The Making of a Special Relationship," 573.
} 
"You have lost a great friend. But you have found a better one." ${ }^{96}$ Edward Tivnan, historian of U.S.-Israel relations, contends that LBJ "was not only a better friend; Johnson became the best friend the Jewish state has ever had in the White House. ${ }^{967} \mathrm{He}$ was the first President to receive an Israeli Prime Minister at the White House. According to Israeli Foreign Minister Abba Eban, President Johnson "established with Prime Minister [Levi] Eshkol the kind of intimate confidence that had never before existed between heads of American and Israeli governments. We no longer had to use the back door for access to the center of American policy." 68

Additionally, Johnson's administration had an unusually high number of pro-Israeli voices. According to Little, "The new president made it a point to place other friends of Israel in key posts in his administration.” Among the friends of Israel: Vice President Hubert Humphrey; Supreme Court Justice Arthur Goldberg, who was appointed America's new ambassador to the U.N.; "the avowedly pro-Israel Rostow brothers" - Walt as national security advisor and Eugene as undersecretary of state for political affairs; John Roche, the President's speech writer and personal confidante, was "among the most outspoken supporters of Israel in the academic world," along with others in Johnson's "kitchen cabinet," an informal group of advisors outside the traditional cabinet. ${ }^{69}$ Importantly, the above-mentioned members of Johnson's administration held significant posts with obvious influence on the president. Secretary of State Dean Rusk supported impartiality, as did a number of ambassadors and White House figures,${ }^{70}$ but the number of "evenhanded" voices was overmatched by the strength of pro-Israeli voices.

\footnotetext{
${ }^{66}$ Ibid. See also Tivnan, 59 and Oren, 26.

${ }^{67}$ Tivnan, 59.

${ }^{68}$ Ibid., 60.

69 "The Making of a Special Relationship," 573.

${ }^{70}$ William B. Quandt, Peace Process: American Diplomacy and the Arab-Israeli Conflict since 1967, Third Edition (Washington D.C.: Brookings Institution Press, 2005) 44.
} 
Moreover, the pro-Israel lobby was becoming a better organized and more powerful influence on U.S. foreign policy. ${ }^{71}$ While not a monolithic organization, the lobby often pushes with a concerted effort, and has a unified goal to foster the development of a special relationship between Israel and the United States. Regarding the lobby's influence of US foreign policy, two particular organizations deserve mention. The Conference of Presidents of Major American Jewish Organizations (President's Conference) has been “an 'umbrella' group responsible for coordinating the activities of more than 30 Jewish groups on virtually all foreign policy issues."72 Started in 1956, the President's Conference meets with the executive branch and foreign dignitaries to discuss policy issues and put forward a particular position, and had no Arab counterpart until $1972 .{ }^{73}$ To influence policy in Congress, Israel has relied on the efforts of the American Israel Public Affairs Committee (AIPAC). “AIPAC presents the 'Jewish position' to members of Congress in much the same way that the President's Conference does to members of the executive branch," says Robert Trice. ${ }^{74}$ These two organizations "funnel the bulk of articulate Jewish opinion on policy issues to governmental decision-makers, ${ }^{75}$ and thereby influence US foreign policy on a level rivaled by few, if any countries. ${ }^{76}$

As the U.S.-Israeli special relationship continued to grow, conditions between Arabs and Israelis continued to deteriorate. Syria and Israel fought over water rights to the Jordan River and

\footnotetext{
${ }^{71}$ John J. Mearsheimer and Stephen M. Walt, The Israeli Lobby and U.S. Foreign Policy (New York: Farrar, Straus and Giroux, 2007). On page 5, the authors offer a simple, useful explanation of the lobby as being "a loose coalition of individuals and organizations that actively works to move U.S. foreign policy in a pro-Israel direction."

${ }^{72}$ Robert H. Trice, "Interest Groups and the Foreign Policy Process: U.S. Policy in the Middle East," Sage Professional Papers: International Studies Series, Volume 4 (Beverly Hills: Sage Publications, Inc., 1976), 37. See also, John J. Mearsheimer and Stephen M. Walt, The Israeli Lobby and U.S. Foreign Policy (New York: Farrar, Straus and Giroux, 2007). The authors offer a simple, useful explanation of the lobby as being "a loose coalition of individuals and organizations that actively works to move U.S. foreign policy in a pro-Israel direction" (5).

${ }^{73}$ Trice, 37.

${ }^{74}$ Ibid., 40.

${ }^{75}$ Ibid.

${ }^{76}$ John Mearshimer and Stephan Walt have argued that the pro-Israel lobby, especially since the end of the Cold War, has been the most important factor shaping U.S.-Israel relations, and by extension, U.S.-Middle East policy. John J. Mearshimer and Stephen M. Walt, The Israel Lobby and U.S. Foreign Policy (New York: Farrar, Straus and Giroux, 2007).
} 
Sea of Galilee. Palestinian guerilla raids steadily increased, usually with sponsorship from Syria, and to a lesser extent, from Jordan. This brought about Israeli retaliations against Syria and Jordan, which added more tension to the region. ${ }^{77}$ During 1966 - the same year that a Ba'athist coup in Syria brought Air Force Commander Hafez al-Assad to power - Israel recorded 93 border incidents, including mines, shooting, and sabotage. ${ }^{78}$ Soviet arms continued to flow to Soviet client states - Syria and Egypt - and the region was heading to another Arab-Israeli war. That war, which erupted in June 1967, redefined the Arab-Israeli conflict.

77 Oren, 23-25.

${ }^{78}$ Oren, 27. 


\section{Chapter 2: \\ The 1967 Arab-Israeli War: Soviet Policy by Other Means?}

The 1967 Arab-Israeli war, which lasted only six days nearly fifty years ago, continues to draw the interest of historians. ${ }^{1}$ In recent years, the role of the Soviet Union in the outbreak of hostilities has been an especially hot topic, with some scholars who see Moscow as deliberately trying to start a war, ${ }^{2}$ while others who see Soviet brinksmanship as having gone too far. ${ }^{3}$ Apart from Soviet involvement, scholars have also assessed the impact of the 1967 war on American foreign policy in the Middle East. Jeremi Suri argues that following the war, support for Israel and Iran foreshadowed the Nixon Doctrine and reliance on regional powers to contain communism, and further, that the "shortcomings" of U.S. policy leading up to the war can be best explained by the Johnson administration's preoccupation with Vietnam and ambivalence towards Israel. ${ }^{4}$ William Quandt and Charles Smith both identify a turning point in American foreign policy in the diplomatic aftermath of the war, with Johnson's "Five Principles" and

\footnotetext{
${ }^{1}$ Two of the leading works on the war are Michael B. Oren, Six Days of War: June 1967 and the Making of the Modern Middle East (New York: Oxford University Press, 2002) and Richard Parker, The Politics of Miscalculation in the Middle East (Bloomington: Indiana University Press, 1993).

${ }^{2}$ Richard Parker has proposed that the Soviet Union played a mysterious role in the outbreak of hostilities, and implies that Moscow may have wanted to start a war - The Six Day War: A Retrospective (Gainesville: University Press of Florida, 1996), as well as The Politics of Miscalculation. Isabella Ginor and Gideon Remez argue that Soviet leadership intentionally tried to start a war in order to provide a pretext for bombing the Israeli nuclear reactor at Dimona, and perhaps to also partake in the fighting - Isabella Ginor and Gideon Remez, Foxbats over Dimona: The Soviets' Nuclear Gamble in the Six-Day War (New Haven: Yale University Press, 2007). From 2000 to 2006, the book's authors had published a series of articles that introduced a slew of new research detailing Soviet efforts to start a war in the Middle East. Ginor and Remez, former journalists in Israel, have done a commendable amount of historical legwork, utilizing interviews with Soviet military personnel, diplomats, and former KGB operatives, along with a detailed reading of declassified Russian and East European documents.

${ }^{3}$ Two fine chapters of edited works, recently published, which support the argument that Soviet leadership aimed to elevate tensions short of war are Boris Morozov, "The Outbreak of the June 1967 War in Light of Soviet Documentation," in The Soviet Union and the June 1967 Six Day War, ed. Yaacov Ro'i and Boris Morozov (Stanford: Stanford University Press, 2008), 43-64; and Rami Ginat, "The Soviet Union: The Roots of War and a Reassessment of Historiography," in The 1967 Arab-Israeli War: Origins and Consequences, ed. William Roger Louis and Avi Shlaim (New York: Cambridge University Press, 2012), 193-218. See also, Galia Golan, "The Soviet Union and the Outbreak of the June 1967 Six-Day War," Journal of Cold War Studies, Volume 8, Number 1, Winter 2006, 3-19.

${ }^{4}$ Jeremi Suri, "American Perceptions of the Soviet Threat Before and During the Six Day War," in The Soviet Union and the June 1967 Six Day War, ed. Yaacov Ro'i and Boris Morozov (Stanford: Stanford University Press, 2008), $120-121$.
} 
support for UN Resolution 242. Both note that Johnson disagreed with Eisenhower's handling of Suez in 1956 and consequently would not force Israel to withdraw from occupied territories until real peace agreements with Arab states were in place. ${ }^{5}$ As such, the war marked an important turning point in which U.S. policy in the Middle East would be more concerned with the U.S.Israel "special relationship" than with Eisenhower's attempt to follow an evenhanded course in the region.

Unfortunately, these two historiographical discussions - Soviet foreign policy and American foreign policy - have not engaged each other. This chapter tries to fill that gap by exploring the shift in American foreign policy before, during, and after the war, coupled with a discussion about Soviet behavior and the geopolitical situation in the Middle East during that time. Only by considering both historiographical concerns - the question of Soviet culpability for the war and the impact of the war on American foreign policy - can scholars understand how the Cold War dynamic shaped both U.S. and Soviet policy towards the Middle East. Although scholars have investigated the 1967 war from a number of different angles, the Soviet stance requires more consideration.

Rather than thinking of Soviet involvement in the prewar crisis only as whether or not the Kremlin intentionally tried to start a war, this paper explores why Soviet officials seemed uninterested in preventing a military conflict during the pre-war crisis. Egyptian President Gamal Abdel Nasser's decision on 22 May 1967 to close the Straits of Tiran and Gulf of Aqaba to

\footnotetext{
${ }^{5}$ William B. Quandt, Peace Process: American Diplomacy and the Arab-Israeli Conflict Since 1967, Third Edition (Washington D.C.: The Brookings Instiution, 2005), 44-47; Charles D. Smith, "The United States and the 1967 War," in The 1967 Arab-Israeli War: Origins and Consequences, ed. William Roger Louis and Avi Shlaim (New York: Cambridge University Press, 2012), 165-192.
} 
Israeli shipping was widely considered a casus belli for Israel. ${ }^{6}$ Soviet leadership had an opportunity to potentially diffuse the threat of war through a cooperative effort in the $\mathrm{UN}$ or by facilitating peace efforts. However, repeated efforts to prevent war, made by major Western powers inside and outside of the UN, were rebuffed by the Soviet Union. One reason for doing so was to provide strong diplomatic support for the Soviet client states in the Middle East Egypt and Syria. But scholars have overlooked another important reason why Moscow was unwilling to take measures to prevent a potential war - to use the heightened tensions in the region to paint a picture of U.S.-Israeli collusion in order to undermine American relations with Arab states. One of the principle aims of Soviet foreign policy in the Middle East was to undermine American interests, ${ }^{7}$ similar to Soviet policy in other parts of the world, like Southeast Asia, Cuba, Berlin, Korea, and various areas in the Third World. And during the runup to war, the Soviet Union was much more interested in trumpeting U.S.-Israeli collusion than with preventing a potential military conflict.

Further, a case can be made that as conditions deteriorated in the Middle East in May 1967, the Soviet Union may have concluded that a military conflict could actually serve their interests and did nothing to prevent the outbreak of war. Although available documentation does not explicitly show that Soviet leadership tried to provoke a war, enough evidence does exist to show that the Kremlin did not try very hard to prevent one from happening, either - a different matter altogether - which makes one wonder about Soviet intentions. Evidence also shows that a number of U.S. officials, including President Johnson, suspected as much. The United States was

\footnotetext{
${ }^{6}$ A lot of Israeli shipping went through this port and the Straits. Following the Suez crisis in 1956-57, Egypt agreed to keep these waterways open to Israeli shipping as part of an agreement that included an Israeli withdrawal from the Sinai and Suez areas. Thus, Nasser's decision to close the straits reopened the wounds from Suez ten years earlier. ${ }^{7}$ Yosef Govrin, Israeli-Soviet Relations 1953-1967: From Confrontation to Disruption (Portland, OR: Frank Cass, 1998), 222, and R. D. McLaurin, The Middle East in Soviet Policy (Lexington: D.C. Heath and Company, 1976), 2425.
} 
already struggling in Vietnam and a Middle East war would only further complicate the American position in both regions of the world. The Kremlin wanted to develop closer relationships with the regimes in Cairo and Damascus as a means for establishing a stronger presence in the Middle East, and an Arab-Israeli war would help to advance that ambition. Even if Egypt and Syria were to be beaten badly by Israel, Moscow could threaten direct intervention (which it did) ${ }^{8}$ to protect friendly regimes, while another military conflict with Israel could only lead to greater animosity between Israel and Soviet client states, creating even closer ties with Moscow as defender of the Arab cause. Moreover, U.S.-Arab relations would certainly be adversely affected by a war because it would force the U.S. to demonstrate a preference for Israel in the ongoing conflict with its Arab neighbors. Thus, even if the Soviet Union did not originally intend to provoke a war, as conditions deteriorated Soviet officials may have come to a similar conclusion as their American counterparts - that a Middle East war would hurt the United States far worse than the Soviet Union.

No matter who won, the very occurrence of an Arab-Israeli war in 1967 would have been devastating to the U.S. position in the region. The American policy of "evenhandedness," established by Eisenhower with the Suez crisis in 1956, had allowed Washington to walk a convenient line of supporting Israel while also maintaining amicable relations with Arab nations. But following the Eisenhower administration, consecutive Democratic presidencies advanced the "special relationship" between the U.S. and Israel while gradually moving away from an evenhanded position. ${ }^{9}$ Yet as long as the status quo remained, American claims of

\footnotetext{
${ }^{8}$ After the USSR severed relations with Israel, and with Israeli forces moving into Syria and bombing Damascus, Alexei Kosygin cabled U.S. President Lyndon Johnson on June 10, warning that if Israeli forces did not cease military action immediately, the Soviet Union would intervene militarily (Oren, 297; Golan, 13).

${ }^{9}$ Douglas Little, "The Making of a Special Relationship: The United States and Israel, 1957-68," International Journal of Middle East Studies, Vol. 25, No. 4 (November 1993), 563-585. Little notes that for over two decades some authors, such as Edward Tivnan, argued that Lyndon Johnson was primarily responsible for the "special relationship." Parting from the standard interpretation, Little sees that relationship truly beginning towards the end
} 
evenhandedness carried legitimate weight. But another military confrontation in the region meant upsetting the existing order and forcing the United States to either reaffirm its outdated policy of evenhandedness or commit to an increasing bias towards Israel. American officials recognized that U.S. national interests would be "gravely" affected if war broke out, and that the threat of war put the U.S. in an impossible position. With a developing special relationship between the U.S. and Israel, a decidedly pro-Israel president and administration in the White House, a sympathetic Congress, a generally pro-Israel electorate, and the Cold War raging with the quagmire in Vietnam, an evenhanded American policy in the Middle East - to the extent that it had actually existed - was a thing of the past. But it took another military confrontation in the Middle East to expose the shift in American foreign policy. Soviet leadership had long been influenced by the writings of military theorist Carl von Clausewitz, and indeed Clausewitz's dictum - "war is an extension of policy by other means" - seems to fit quite well in this situation. ${ }^{10}$ War became a means for the Soviet Union to achieve a political victory in the Cold War by forcing into the open a developing American-Israeli informal alliance and complicating American relations with Arab states, a scenario that has been overlooked in scholarship. ${ }^{11}$

of the Eisenhower presidency, advancing under Kennedy, and becoming operative U.S. policy with Johnson. According to Little, Eisenhower and Kennedy both laid the groundwork for the burgeoning alliance as a means to repel Soviet advances in the region, protect against Arab nationalism, and convince Israel not to pursue nuclear proliferation; Johnson basically continued an existing trend.

${ }^{10}$ Soviet leadership, beginning with Lenin, thought highly of Clausewitz. According to Soviet historian Vladislav M. Zuboc, the Soviet General Staff "always held the Prussian theorist in high regard. Clausewitz's legacy was always part of the party ideological exegesis because Friedrich Engels had admired his views on war and Lenin commented on it, too. In 1947 Stalin returned to Clausewitz to confirm that he had foreseen the Marxist-Leninist idea that 'there is a direct connection between war and politics, that politics generates war, and that war is continuation of politics by violent means." Failed Empire: The Soviet Union in the Cold War from Stalin to Gorbachev (Chapel Hill: University of North Carolina Press, 2007), 378-79.

${ }^{11}$ In contemplating what the USSR had to gain from war, scholars have offered a number of different scenarios, yet the possibility that the Kremlin was trying to undermine U.S. policy has been overlooked. Ginor and Remez believe that Soviet leadership hoped to use war to as a pretext for bombing the Israeli nuclear reactor at Dimona and potentially to partake in the actual fighting. Morozov suggests that the Soviets only had two potential reasons for wanting war - the expectation that Arab states could actually win or, on the other hand, a defeat by Israel would make Syria and Egypt even more reliant on Moscow. However, Morozov concludes that Moscow ultimately had nothing to gain from war and likely sought to avoid one (Ro'i and Morozov, 47-56). Similarly, Golan argues that "war seemed to be a no-win proposition for the Soviet Union" (Golan, 7-8). In The 1967 Arab-Israeli War: Origins 
Soviet misinformation was the main catalyst for the war. On 13 May 1967, Egyptian officials received Soviet warnings of a massive Israeli troop buildup on the Syrian border, and further, that Israel was preparing for an imminent attack. ${ }^{12}$ Two days after receiving the Soviet report, Egyptian troops began moving through Cairo toward the Sinai Peninsula. The following day, Nasser asked the United Nations Emergency Force (UNEF) to withdraw from the Sinai and Gaza Strip; UN Secretary General U Thant ordered the withdrawal of UNEF on 18 May. Three days later, Nasser mobilized reserves and announced the decision to bar Israeli ships from entering the Gulf of Aqaba and the Straits of Tiran the next day, in violation of the agreement reached in 1957. After the closure of the Straits, Israeli officials began pleading with President Johnson to give his blessing to unilateral Israeli action. According to William Quandt, Johnson's initial "red light" on 26 May turned into a "yellow light" by 3 June, which was enough to convince Israel to attack on the morning of 5 June. ${ }^{13}$

But the Soviet reports were obviously false, a point made by various intelligence reports at the time. Egyptian officials and the CIA both concluded that there was no merit to the Soviet claims. ${ }^{14}$ A telegram from the U.S. Embassy in Israel to the Department of State echoed these reports: "no Israeli troop concentration Syrian, Egyptian or other frontier. (This corresponds with U.S. Attachés reconnaissance to this hour.)"15 Another telegram explained that "Egypt has been

and Consequences, Rami Ginat recognizes that some scholars have argued that Moscow was responsible for the war, pointing to "Soviet domestic politics" and "external factors connected with the Cold War" (Ginat, 194). Yet Ginat argues that Israel, Egypt, and Syria are responsible for the war - not Moscow (Ginat, 215).

${ }^{12}$ Parker, Politics, 5. Anwar El Sadat, In Search of Identity: An Autobiography (New York: Harper \& Row, 1978), 172. And as Ginat points out on page 203 in Origins and Consequences, this was not the first Soviet warning about Israeli troop concentrations, as several had been made in the previous year.

${ }^{13}$ Quandt, 41.

14 Oren, 64.

15 Telegram from Embassy in Israel to Department of State, 15 May 1967, The Foreign Relations of the United States (hereafter, FRU.S.), 1964-1968, Volume XIX, Arab-Israeli Crisis and War, 1967, Document 2. 
informed by those who should know including the U.S. that there were no Israeli concentrations opposite Syria."16

Due to rising tensions in the region, the Soviet reports seemed plausible. Terrorist attacks from Syria into Israel had steadily increased after the Ba'athist revolution in Syria in February 1966. The situation boiled over in April 1967 after Israel noticed "a sharp increase in the sophistication of attacks," and during an air battle on 7 April, Israel destroyed six Syrian MIGs jet fighters from Russia. ${ }^{17}$ Prime Minister Levi Eshkol communicated to President Johnson on 18 May that "there have been 15 attempts at murder and sabotage in the past six weeks," continuation of terrorist attacks convinced Israeli leaders to publicly threaten action, ${ }^{19}$ which gave Soviet warnings a ring of truth.

Nasser did not want a military conflict with Israel but felt obligated to support his Arab allies. Egypt's ongoing war in Yemen had severely limited Nasser's military options. Veteran personnel were in Yemen, and Nasser was forced to default on \$1 billion in foreign loans and also to cut defense spending. ${ }^{20}$ But Nasserism, a pan-Arab campaign advanced by the movement's namesake, had significantly ebbed by 1967 with questions about Nasser's commitment to the collective Arab cause. National Security Advisor Walt Rostow informed President Johnson that "Nasser probably feels his prestige would suffer irreparably if he failed a

\footnotetext{
${ }^{16}$ Telegram from the Embassy in Israel to Department of State, 18 May 1967, FRUS, 1964-1968, Volume XIX, Arab-Israeli Crisis and War, 1967, Document 14.

${ }^{17}$ Saunders to Bundy, sometime prior to 19 June 1967, "Terrorist Origins of the Present Crisis," National Security Files (hereafter, NSF), National Security Council History (hereafter, NSCH), Box 17, Middle East Crisis, Volume 1, Tabs 1-10, Lyndon B. Johnson Presidential Library (hereafter, LBJL). "Chronology: The June War - - Before and Following,” 25 March 1968, NSF, NSCH, Box 17, Middle East Crisis, Volume 1, Tabs 1-10, LBJL.

${ }_{18}$ Telegram from the Embassy in Israel to Department of State, 18 May 1967, FRUS, 1964-1968, Volume XIX, Arab-Israeli Crisis and War, 1967, Document 13.

${ }^{19}$ Memorandum from the President's Special Assistant (Rostow) to President Johnson, 15 May 1967, FRU.S., 19641968, Volume XIX, Arab-Israeli Crisis and War, 1967, Document 4. Says Rostow, "Border tension mounted sharply over the weekend after Eshkol and the Israeli Chief of Staff threatened an attack if terrorist raids from Syria into Israel continue. The UAR has ostentatiously put its forces on alert."

${ }^{20}$ Oren, 40, 37.
} 
third time to come to the aid of an Arab nation attacked by Israel. Moderates like [Jordan's King] Hussein have raked him over the coals for not coming to Jordan's aid in November or to Syria's when Israel shot down 6 of its MIG's last month." ${ }^{21}$ Although King Hussein of Jordan signed a defense pact with Egypt just days before the war, he was surprised by the extent of Nasser's saber-rattling. Hussein told Western diplomats that Nasser was "acting like a madman," banking on untold Soviet backing. ${ }^{22}$ Syria, likewise, claimed to have "the full backing of the Soviet Union." ${ }^{23}$

The Johnson administration considered the possibility that Moscow was trying to stir up a war in the Middle East but dismissed the idea because it did not fit with Washington's view of Soviet foreign policy. As early as 19 May, George C. Denney, Jr., Director of the State Department's Bureau of Intelligence and Research (INR), communicated to Secretary of State Dean Rusk, "Soviet policy has always smacked of brinkmanship," but "we do not believe that the Soviet Union intends to go beyond its usual readiness to exploit squabbling within tolerable bounds." Ultimately "Moscow would not see the risk of a war, the end of which could not be foreseen, as a useful means of harassing the U.S." ${ }^{24}$ From a 23 May meeting of the Department of State, "It was the consensus that the Soviets probably do not want a blow-up in the Middle East based on our knowledge here of Soviet intent." ${ }^{\prime 25}$ The following day, in a National Security Council meeting, President Johnson specifically asked whether or not the Soviets "had staged this Middle East crisis," but neither Chairman of the Joint Chiefs of Staff Earle Wheeler nor CIA

\footnotetext{
${ }^{21}$ Memorandum from the President's Special Assistant (Rostow) to President Johnson, 17 May 1967, FRU.S., 19641968, Volume XIX, Arab-Israeli Crisis and War, 1967, Document 7.

${ }^{22}$ Oren, 128.

${ }^{23}$ Telegram from the Embassy in the Soviet Union to the Department of State, 23 May 1967, FRUS, 1964-1968, Volume XIX, Arab-Israeli Crisis and War, 1967, Document 41; also, Ginor and Remez, 108.

${ }^{24}$ Denney to The Secretary, 19 May 1967, NSF, NSCH, Box 19, Middle East Crisis, Volume 6, Appendices A-D, LBJL.

${ }^{25}$ Memorandum by the Executive Secretary of State (Read), 23 May 1967, FRUS, 1964-1968, Volume XIX, ArabIsraeli Crisis and War, 1967, Document 48.
} 
Director Richard Helms believed the Kremlin was to blame, although the USSR likely regarded the situation "as a godsend." Later in the meeting, President Johnson returned to Soviet motives, and Helms claimed the USSR probably wanted to be seen as "peacemakers and saviors of the Arabs, while we end up fully blackballed in the Arab world as Israel's supporter."26

American officials recognized that the Soviet Union was trying to force the U.S. and Israel closer together while driving a wedge between the U.S. and Arab world. After transmitting messages to Syria and Egypt about Israeli attack plans, Soviet propaganda concentrated on "pushing the United States into the forefront of the Middle East crisis by making Washington responsible for Israel's actions." ${ }^{27}$ According to a CIA report on 25 May, "We believe the Soviet aim is still to avoid military involvement and to give the U.S. a black eye among the Arabs by identifying it with Israel. Once this is accomplished - and this is happening fast - we think that the Soviets will not wish to increase the crisis further." 28 Another CIA memo opined that "we do not believe that they want a Middle East war," but "one almost certain objective of the Soviets is to see the U.S. more firmly and publicly identified with Israel." Such a plan "would further weaken the U.S. position in the area, threaten U.S. oil interests, and strengthen the Soviet position." 29 Foreign Service officer Lucius Battle informed President Johnson of "a vigorous Soviet effort to turn this crisis into a U.S.-Arab confrontation.” He followed by saying, "whatever we do we are in trouble. If we fail to stand by Israel, the radical Arabs will paint us as

\footnotetext{
${ }^{26}$ Memorandum for the Record, 24 May 1967, FRUS, 1964-1968, Volume XIX, Arab-Israeli Crisis and War, 1967, Document 54.

${ }^{27}$ Quoted in Ginor and Remez, 107.

${ }^{28}$ Memorandum from the President's Special Assistant (Rostow) to President Johnson, 25 May 1967, FRU.S., 19641968, Volume XIX, Arab-Israeli Crisis and War, 1967, Document 61.

${ }^{29}$ Memorandum from the Central Intelligence Agency's Board of National Estimates to Director of Central Intelligence Helms, 26 May 1967, FRU.S., 1964-1968, Volume XIX, Arab-Israeli Crisis and War, 1967, Document 79.
} 
a paper tiger. If we stand by Israel, we will damage ourselves seriously with all the Arabs." ${ }^{30}$ The U.S. embassy in Cairo supported "dissociation from appearances of support for Israel versus Arabs and strictly toward UAR-Israel confrontation. We should remain neutral in this confrontation ... Otherwise, we foresee heavy cost to U.S. in terms political, economic and other relationships in Arab world, and in terms cold war balance of power." 31 Washington considered giving explicit, public support for Israeli shipping through Tiran, but such a move "would gravely undermine, if not destroy, U.S. position throughout the Arab world." 32 American officials wanted desperately to prevent "a war which could gravely damage many American national interests." 33

Recently declassified Soviet documents have enabled scholars to reconstruct the Soviet perspective in the weeks leading up to war and to reassess the Soviet role in the outbreak of war in 1967. In their respective works, Boris Morozov, Rami Ginat, and Galia Golan all pay particular attention to Soviet misinformation that led to war. ${ }^{34}$ Ginat argues that "Soviet intelligence information was not without foundation," based on the report of the "Egyptian military establishment" and Soviet interpretations of Israeli threats against Syria. ${ }^{35}$ Golan downplays the official nature of the Soviet reports and figures that the false information was passed in order to create more domestic support for the wobbly Ba'athist regime that had

\footnotetext{
${ }^{30}$ Memorandum for the Record, 26 May 1967, FRUS, 1964-1968, Volume XIX, Arab-Israeli Crisis and War, 1967, Document 72.

${ }^{31}$ Telegram from the Embassy in the United Arab Republic to the Department of State, 26 May 1967, FRUS, 19641968, Volume XIX, Arab-Israeli Crisis and War, 1967, Document 67.

32 Telegram from the Embassy in the United Arab Republic to the Department of State, 30 May 1967, FRUS, 19641968, Volume XIX, Arab-Israeli Crisis and War, 1967, Document 100.

${ }^{33}$ Memorandum from Secretary of State Rusk to President Johnson, 26 May 1967, FRUS, 1964-1968, Volume XIX, Arab-Israeli Crisis and War, 1967, Document 71.

${ }^{34}$ Morozov has held the position of Research Fellow at the Cummings Center for Russian and East European Studies at Tel Aviv University; Ginat and Golan are both accomplished political scientists who specialize in Israeli foreign policy.

${ }^{35}$ Ginat, 207.
} 
recently come to power, which Golan argues was the reason for previous similar Soviet reports. ${ }^{36}$ Morozov, in contrast to Golan, emphasizes the official nature of the reports, detailing how the Politburo sent three different messages to ambassadors in Cairo and Damascus, asking them to pass along Soviet reports of Israeli troops massing on the Syrian border and that Israel planned to attack. Although Golan believes that hardliners within the upper levels of Soviet leadership like Defense Minister Andrei Grechko or Aleksandr Shelepin - may have aimed to elevate tensions to gain a better presence in the region, Morozov disputes this based on his research. ${ }^{37}$ While Golan, Ginat, and Morozov take different positions about the nature of Soviet misinformation, all three agree that Moscow seemingly had nothing to gain from war. ${ }^{38}$ In particular, Morozov concludes that Soviet leadership knowingly passed along false information, but dismisses the possibility that Moscow wanted to start a war because Morozov sees no potential benefit for the Soviets. Perhaps Moscow believed the Arab states would defeat Israel, but Morozov shows that Soviet leadership had objective evidence of Israel's military superiority. Specifically, Morozov cites a memorandum written by Petr Ivashutin, head of the GRU (the Main Intelligence Directorate of the Ministry of Defense). According to Morozov, the main points of the memorandum are as follows: "the situation could lead to war; Israel enjoyed military superiority and there was a high probability of an Israeli victory in the event of war; yet war could be avoided, since Israel was conducting itself less aggressively, and the Western powers were not interested in war, nor indeed Egypt." ${ }^{39}$ Perhaps Moscow planned to benefit from an Arab defeat by establishing a stronger presence in the region, but Morozov contends that defeat meant a potential change of regime in either Cairo or Damascus, and Arab prestige would

\footnotetext{
${ }^{36}$ Golan, 7.

${ }^{37}$ Morozov, 45-63.

${ }^{38}$ Ginat, 214; Golan, 7-8; and Morozov, 48-49.

${ }^{39}$ Morozov, 50.
} 
be wounded in the Third World. ${ }^{40}$ Ultimately, Morozov advances a traditional interpretation that posits Soviet leadership wanted to escalate tensions to make Syria and Egypt more dependent on the Soviet Union, but to stop short of war. ${ }^{41}$

While Ginat acknowledges that Soviet leadership was "complacent" during the run-up to war, ${ }^{42}$ and Golan admits that Moscow may have sent confusing signals to its allies, ${ }^{43}$ Morozov argues that the Kremlin took several steps to prevent war. According to Morozov, the Kremlin did not try to start a war, but instead Soviet "mistakes and miscalculations brought the situation to the brink of war, which the Soviet leaders did not want and tried to prevent up to the very last moment. ${ }^{\text {"44 }}$ Regarding steps to prevent a war, Morozov explains that in the early morning of 27 May, Nasser received a Soviet message that requested him to do everything possible to prevent a military conflict. According to the official historian of the Russian Defense Ministry, Egypt had planned to attack first until it received word that the Soviet Union would not support Egypt if it attacked first. ${ }^{45}$ Additionally, Soviet officials met with Nasser on 1 June to explore possible ways to avoid war. ${ }^{46}$

Aside from communications with Nasser, however, Moscow did little else to prevent a military conflict. Morozov claims that Soviet leaders also organized "diplomatic support for Nasser's moves and preserving the new status quo," attempted "to calm Israel and urge it to back

\footnotetext{
${ }^{40}$ Ibid., $48-51$.

${ }^{41}$ Ibid., 56.

${ }^{42}$ Ginat says on page 211, "During the period from 14 May to 4 June 1967, the Soviets were complacent. They did not anticipate an Israeli preemptive attack without direct American involvement."

${ }^{43}$ Golan notes on page 9, "The debate about Soviet intentions in transmitting false information is paralleled by a similar debate about the escalation of the crisis and the possibility of war. Specifically, analysts have sought to determine whether Soviet leaders in May 1967 intended to encourage Nasser to move ahead, confident of Moscow's support, in preempting an Israeli attack; or, whether they wanted him to proceed cautiously, ease the pressure and be prepared for U.S. involvement that Moscow might or might not be willing to counter. In fact both messages may have been delivered, representing two different positions within the Soviet hierarchy."

${ }^{44}$ Ibid., 56.

${ }^{45}$ Ibid., 57; Golan, 10.

${ }^{46}$ Ibid.
} 
down," and finally, "Moscow sought to use the influence of the Western powers to avoid a war." ${ }^{\prime 7}$ But upon investigation, these steps to "prevent" war appear to be without foundation. First, by supporting the new status quo, which included Nasser's decision to block Israeli shipping through the Straits of Tiran in violation of the agreement made in 1957, the Soviet Union actually furthered the risk of war. Indeed, the Soviet Union supported Egypt's move to close the Straits and expel UNEF. ${ }^{48}$ Second, Soviet officials made little effort to calm Israeli fears. The Soviet Union ignored the Israeli request of 27 May for a meeting with Soviet leadership to try to deescalate tensions after Syria objected to the meeting. ${ }^{49}$ Perhaps more importantly, Israeli Foreign Minister Abba Eban warned the Soviet Union on 30 May that if the great powers failed to resolve the issue with the Straits, Israel would open them itself; the Kremlin responded on 2 June with a note "expressing profound dissatisfaction with Eban's statement" in that Israel would choose military action - hardly a soothing response. ${ }^{50}$ As Yosef Govrin points out, Soviet alarm was not over the blockade itself but over Eban's declaration. ${ }^{51}$ Last, contrary to Morozov's argument, Moscow avoided, rather than engaged, the West in efforts to find a diplomatic solution to the crisis. In particular, as shown below, Moscow resisted peace efforts made by Western powers and the consensus of the Western community was that in order to avoid war, the Soviet Union needed to act more responsibly.

Soviet behavior at the UN was hard to explain, if one assumes that Moscow was intent on preventing war. Moscow sought to provide its Middle East allies with diplomatic support, and in

\footnotetext{
${ }^{47}$ Ibid., 57-59.

${ }^{48}$ Govrin, 310-311. Govrin includes conversations and messages between high-ranking Soviet and Egyptian officials by citing Pravda. Ginor and Remez, 106.

${ }^{49}$ Rami Ginat, "The Soviet Union: The Roots of War and a Reassessment of Historiography," in The 1967 ArabIsraeli War: Origins and Consequences, ed. William Roger Louis and Avi Shlaim (New York: Cambridge University Press, 2012), 210.

${ }^{50}$ Morozov, 59.

${ }^{51}$ Govrin, 318.
} 
fact declassified Soviet documents reveal that the Politburo informed Soviet UN Ambassador Nikolai Fedorenko that he was to coordinate with Egypt and Syria, pledge support for recent moves by Egypt, and to oppose peace talks in the Security Council if opposed by Egypt and Syria. ${ }^{52}$ Following Egypt's closure of the Straits, Brezhnev stated in a speech that "in the United Nations Organization we did everything that depended on us, comrades, to lessen the pressure of the Western superpowers on the UAR in connection with the question of the free passage in the Aqaba Gulf." ${ }^{53}$ Rather than restrain Egypt, as U.S. ambassador to the USSR Llewellyn Thompson reported, Soviet leadership believed "that the reason for the current tension was the policy of Israel, and certain circles or groups in Israel which had determined this policy." According to Thompson, Minister of Foreign Affairs Andrei Gromyko thought the U.S. should use its "special relations" with Israel to keep it from making matters worse. ${ }^{54}$

However it seems Moscow was either unable or unwilling to find ways to support its allies while furthering the cause of peace. Arthur Goldberg, U.S. Ambassador to the UN, told Secretary General U Thant on 20 May that "we were receiving confusing signals from Sovs. Noted I had obtained nothing really from Fedorenko except his statement USSR did not want war ..." Also disturbing, after the expulsion of UNEF from Egypt, "Ukrainian and Byelorussian reps yesterday had expressed satisfaction over current situation and noted UN ought to get out of peace-keeping business and that Fedorenko had said this demonstrated undesirability of UN force under SYG [Secretary-General] control." Even further, "Sovs appeared to be supporting stories of U.S. involvement and even to have initiated them." ${ }^{55}$ Fedorenko balked at Goldberg's

\footnotetext{
${ }_{52}^{52}$ Morozov, 57-58.

${ }^{53}$ Quoted in Ginor and Remez, 106.

${ }^{54}$ Telegram from the Embassy in the Soviet Union to the Department of State, 23 May 1967, FRUS, 1964-1968, Volume XIX, Arab-Israeli Crisis and War, 1967, Document 41.

${ }^{55}$ Telegram from the Mission to the United Nations to the Department of State, 20 May 1967, FRUS, 1964-1968, Volume XIX, Arab-Israeli Crisis and War, 1967, Document 26.
} 
suggestion in the evening of 23 May for a Security Council meeting to diffuse the situation: "he argued that SC mtg not necessary now; various govts concerned, including our own, have just made statement on this issue which should suffice." Goldberg also noted Fedorenko had "studiously avoided contact with other SC members." ${ }^{56}$ In a recent article, Goldberg recalled that attempts to prevent war "made in the Security Council and those made through private diplomatic channels failed because of Arab objections that were supported by the Soviet Union. Apparently, both the Arab states and the Soviet Union were willing to risk war."

The Soviet Union maintained an uncooperative stance with other Western nations at the UN. Fedorenko, upon instructions from Gromyko, effectively resisted efforts to lift the blockade on Israeli shipping to the point that Canadian and Dutch representatives "had a nasty feeling [that the] USSR [was] playing [a] game of allowing crisis to build to force Israel to act." 58 Israel concluded on 26 May that action through the UN would almost certainly fail because of "Russian intransigence." ${ }^{59}$ According to a report from the Israeli delegation at the UN, French President Charles de Gaulle warned that Nasser and the Soviet Union were trying to provoke Israel into initiating hostilities, and that Israel should refrain from attacking first. ${ }^{60}$ The U.S., UK, and France wished to have a four-power meeting with the USSR (intentionally avoiding Chinese participation to butter-up to Moscow), either inside or outside the UN. But U.S. Undersecretary for Political Affairs Eugene Rostow noted that the "Soviets have been unwilling." 61 The British ran into similar problems. Foreign Secretary George Brown did not think "the Russians would be

\footnotetext{
56 Telegram from the Mission to the United Nations to the Department of State, 24 May 1967, FRUS, 1964-1968, Volume XIX, Arab-Israeli Crisis and War, 1967, Document 51.

${ }^{57}$ Arthur J. Goldberg, "What Resolution 242 Really Said,” American Foreign Policy Interests, 33, $2011,42$.

${ }^{58}$ Quoted in Ginor and Remez, 107.

${ }^{59}$ Memorandum of Conversation, 26 May 1967, FRUS, 1964-1968, Volume XIX, Arab-Israeli Crisis and War, 1967, Document 69.

${ }^{60}$ Zaki Shalom, The Role of U.S. Diplomacy in the Lead-Up to the Six Day War: Balancing Moral Commitments and National Interests (Portland, Oregon: Sussex Academic Press, 2012), 136.

${ }^{61}$ Telegram from the Department of State to the Mission to the United Nations, 24 May 1967, FRUS, 1964-1968, Volume XIX, Arab-Israeli Crisis and War, 1967, Document 57.
} 
willing to work with us constructively in the Security Council." Regarding a four-power meeting, "Brown was not sure the Soviets would be willing to do anything about this proposal. Brown had mentioned it to Gromyko, who had not responded." ${ }^{22}$ For his part, U Thant was "pessimistic about anything helpful happening in the UN" and felt the "crisis must be solved ... through Moscow." ${ }^{\prime 3}$ But as late as 2 June, the U.S. government believed that "the Soviets would veto anything calling for the parties to forego belligerency." ${ }^{64}$ On 4 June - the day before the war - Walt Rostow communicated to President Johnson, "In the end, whether the outcome is an Arab-Israeli war or a successful transit of the situation depends a good deal on the USSR." ${ }^{965}$

Suspicious Soviet behavior was reported from various sectors. According to a 20 May telegram, Moscow reportedly told Israel that the CIA was responsible for terrorist attacks on the Syrian border, which Israeli ambassador Avraham Harman believed, "raised possibility that we're getting double talk from the Soviets." Harman felt the Soviets and Syrians were "pointing fingers" and that the "situation raised possibility of Soviet-Syrian-Egyptian collusion." 66 According to Thompson, "From the way the Soviets are handing the Middle East crisis, I conclude that they were well aware of Egyptian plans and probably not averse to the Egyptian action in stirring up this affair." For Thompson, who believed that the Soviets were interested in an Arab-Israeli war, "Even if the Israelis should clobber their Arab neighbors, the Soviets might calculate that the hatred this would engender for the West would enable them to reestablish their

\footnotetext{
${ }^{62}$ Memorandum of Conversation, 25 May 1967, FRUS, 1964-1968, Volume XIX, Arab-Israeli Crisis and War, 1967, Document 58.

${ }^{63}$ Telegram from the President's Special Assistant (Rostow) to President Johnson in Texas, 29 May 1967, FRUS, 1964-1968, Volume XIX, Arab-Israeli Crisis and War, 1967, Document 95.

${ }^{64}$ Memorandum of Conversation, 2 June 1967, FRUS, 1964-1968, Volume XIX, Arab-Israeli Crisis and War, 1967, Document 132.

${ }^{65}$ Memorandum from the President's Special Assistant (Rostow) to President Johnson, 4 June 1967, FRU.S., 19641968, Volume XIX, Arab-Israeli Crisis and War, 1967, Document 144.

${ }^{66}$ Telegram from the Department of State to the Embassy in Israel, 20 May 1967, FRUS, 1964-1968, Volume XIX, Arab-Israeli Crisis and War, 1967, Document 25.
} 
position in the Arab world." ${ }^{967}$ Meanwhile, the Soviet Ambassador to Israel claimed Moscow did "not want war in the Middle East," but the Israelis claimed that "this is not what the Egyptian War Minister Moscow telling Cairo."68 The French Minister of Foreign Affairs, Couve de Murville "agreed that the Soviets' behavior is far from clear ... they had not shown any inclination to act responsibly in the present crisis." ${ }^{69}$ According to a KGB agent on $31 \mathrm{May}$, the Soviet Union could only win from the current crisis in the Middle East - "No matter how it went, and whether or not there was an Israeli-Arab war, the United States would suffer a disastrous blow to its prestige and influence."70 On 4 June, Israel and the U.S. agreed that Moscow was stonewalling peace efforts and Israeli officials believed the "USSR prodding Egypt" to attack. ${ }^{71}$ Israel attacked Egypt the next day.

Even during the war, Moscow seemed unwilling to work constructively with Washington. Soviet and Egyptian propaganda continued to paint a picture of U.S.-Israeli collusion, even to the point of accusing American participation in military acts against Arab states. Johnson was outraged by the baseless, inflammatory rumors that jeopardized American lives in the Middle East and told Kosygin as much in three separate letters. On 6 June, Johnson claimed to be "puzzled" by "Soviet press and radio" charges of involvement in hostilities, “especially when our only role has been to press for restraint at every step of the way." Egypt had "alleged that U.S. carrier aircraft had participated in attacks on Egypt," and "This wholly false and obviously invented charge has led to attacks on our representatives in various Arab

\footnotetext{
${ }^{67}$ Ginat, 196. Telegram from the Embassy in the Soviet Union to the Department of State, 25 May 1967, FRUS, 1964-1968, Volume XIX, Arab-Israeli Crisis and War, 1967, Document 59.

${ }^{68}$ Telegram from the Embassy in Israel to the Department of State, 27 May 1967, FRUS, 1964-1968, Volume XIX, Arab-Israeli Crisis and War, 1967, Document 82.

${ }^{69}$ Telegram from the Embassy in France to the Department of State, 2 June 1967, FRUS, 1964-1968, Volume XIX, Arab-Israeli Crisis and War, 1967, Document 133.

${ }^{70}$ Ginat, 211.

${ }^{71}$ Telegram from the Department of State to the Embassy in Israel, 4 June 1967, FRUS, 1964-1968, Volume XIX, Arab-Israeli Crisis and War, 1967, Document 140.
} 
localities." U.S. aircraft carriers in the Middle East had been shadowed by Soviet ships since 2 June, according to intelligence reports, which meant Moscow knew that the U.S. ships were nowhere near the conflict. That explains why Johnson cabled, "Since you know where our carriers are, I hope you can put Cairo right on this matter and help us eliminate that kind of needless inflammation." ${ }^{72}$ The next day, after hearing about Egyptian reports of U.S. air involvement in the war, Johnson cabled Kosygin that the "false and invented charges" have resulted "in mob action against American embassies and consulates and a break in Diplomatic Relations by seven Arab countries with the United States. This despicable act ... will lead to a very serious deterioration in the situation." ${ }^{73}$ On 10 June, Johnson again communicated his displeasure about the persistent charges of American military involvement, stating "that President Nasser yesterday repeated his outrageous invention about American and British participation in this conflict." ${ }^{\text {"74 }}$ The U.S. government felt obligated to cable King Hussein an outright denial of such allegations on 10 June, mentioning that UN Ambassador Goldberg had declared on 6 June that the U.S.G would allow a UN investigation of American aircraft carriers, if need be. ${ }^{75}$

Gradually, American officials began admitting that Soviet behavior was quite peculiar. A few days before the war, Denney informed Rusk that Soviet misinformation and propaganda "does not seem to have had the purpose of inciting the Arabs to take the initiative in moving against Israel first, although, admittedly, it went considerably beyond the norm of Moscow's

\footnotetext{
${ }^{72}$ Message from President Johnson to Premier Kosygin, 6 June 1967, FRUS, 1964-1968, Volume XIX, Arab-Israeli Crisis and War, 1967, Document 175.

${ }_{73}^{73}$ Message from President Johnson to Premier Kosygin, 7 June 1967, FRUS, 1964-1968, Volume XIX, Arab-Israeli Crisis and War, 1967, Document 193.

${ }^{74}$ Message from President Johnson to Premier Kosygin, 10 June 1967, FRUS, 1964-1968, Volume XIX, ArabIsraeli Crisis and War, 1967, Document 252.

${ }^{75}$ Telegram from the Department of State to the Embassy in Jordan, 10 June 1967, FRUS, 1964-1968, Volume XIX, Arab-Israeli Crisis and War, 1967, Document 261.
} 
usual pro-Arab and anti-Israeli propaganda output." ${ }^{, 76}$ According to a 9 June memo, Abbot Smith, the Acting Chairman of the Office of National Estimates of the CIA, believed Nasser's decision to close the Gulf was probably without Soviet counsel, although Smith admitted, "The evidence on this matter is fairly skimpy ... But our belief that the Soviets did not approve of the Gulf closure rests partly on our judgment that the Soviets were well aware that this one move could provoke an Arab-Israeli war.” Although Smith was dismissive of the idea that Moscow instigated the war, he recognized, "The Soviets still have impressive advantages in the area, the principal ones being the high tide of anti-U.S. and anti-Israeli feeling, and the Arab belief that the USSR is the only major power likely to provide support for them in the foreseeable future." Smith rightly concluded, "The Soviets probably believe that the U.S. has suffered more severe and lasting political losses in the Arab world than they have." 77

The Johnson administration tried in vain to maintain an evenhanded position. On 30 May, Goldberg reminded the UN Security Council, American foreign policy had "a record of evenhanded conduct between the parties. It is a one-sided record in the cause of peace ..."78 On 5 June, the first day of the war, Robert McCloskey at the State Department declared, "We have tried to steer an even-handed course ... Our position is neutral in thought, word and deed."79 McCloskey's statement drew the ire of the American Jewish community, which communicated its "sharp disillusion and dismay" to the White House, suggesting that an evenhanded course like

\footnotetext{
${ }^{76}$ Denney to The Secretary, 1 June 1967, NSF, NSCH, Box 19, Middle East Crisis, Volume 6, Appendices A-D, LBJL.

${ }^{77}$ Abbot Smith, Central Intelligence Agency, Office of National Estimates, Memorandum for the Director, 9 June 1967, NSF, NSCH, Box 19, Middle East Crisis, Volume 6, Appendix 7I (1-3), LBJL.

78 "Official U.S. Government Statements on Basic Issues Concerning the Middle East Crisis, May 18-June 13, 1967," U.S. Information Agency, The Agency Library, 16 June 1967, NSF, NSCH, Box 20, Middle East Crisis, Volume VIII, Appendices N-O, LBJL, 44.

${ }^{79}$ Ibid., 45.
} 
the one implemented by Eisenhower would be furiously challenged by the powerful pro-Israel lobby. ${ }^{80}$ That same day, President Johnson drafted a letter to Harold Saunders that noted, "We have done everything we could to get an even-handed Security Council pronouncement." 81

Johnson communicated the American position to King Faisal of Saudi Arabia in a letter cabled on 8 June. Johnson assured Faisal that "we will strive to steer an even-handed course. Our sole endeavor will be to seek the earliest feasible return to peaceful conditions so that the underlying problems of the region can be addressed in relative calm." Johnson pre-empted the growing perception of U.S.-Israeli collusion, claiming to not have "favoritism for any single state in the region" and that "the purpose of the United States Government must remain the prevention and limitation of hostilities ... Such has been our settled policy under four Administrations of both political parties since the end of World War II." 82

Some administration officials stressed the need to continue an evenhanded position and not appear biased by Israeli sympathies. Benjamin Read, the Executive Secretary for Dean Rusk, informed McGeorge Bundy that it was in "our national interest" to maintain "reasonably friendly relations with both Israel and the Arab states" in order to "preserve some continuing role in the development of petroleum and other resources." But the task would be difficult because "on one side, we face an even more alienated Arab world ... partly because of Soviet stimulation ..." and "special ties with Israel” further complicated the situation. "On the other side, the Israeli attitude presents a further obstacle ... They will be more convinced than ever that readiness to use force on their own is their best defense against Arab weight of numbers. And their leverage in U.S.

\footnotetext{
${ }^{80}$ Message from Larry Levinson and Ben Wattenberg of the White House Staff to President Johnson, 7 June 1967, FRU.S., 1964-1968, Volume XIX, Arab-Israeli Crisis and War, 1967, Document 198.

${ }^{81}$ Johnson to Saunders, 5 June 1967, Papers of LBJ, NSF, CO, Box 106, Middle East Crisis, Memos \& Misc. [1 of 4], Volume II, LBJL.

${ }^{82}$ Johnson to Faisal, 8 June 1967, Papers of LBJ, NSF, CO Box 107 [2 of 2], Middle East Crisis, Memos [1 of 3], Volume IV, LBJL.
} 
domestic politics can limit our flexibility." In conclusion, "we must avoid full commitment to either side or to any party ... Our influence is greatest if we serve as a balance, not a partisan." ${ }^{" 83}$ Zbigniew Brzezinski, a member of the State Department's policy planning staff and future National Security Adviser for Jimmy Carter, offered an insightful assessment of the difficulties facing the United States government. Soon after the war Brzezinski predicted that "the Soviet tactic will be to drive the United States into increasingly explicit support of Israel ... thereby gaining for the Soviet Union the sympathies of the entire Arab world, radicalizing in the process Arab political leadership." For Brzezinski, maintaining a detached position would be difficult "in the face of the Soviet diplomatic onslaught and the necessity to take a stand in the General Assembly." But at the same time, "Adopting an active pro-Israel position will mean not only a head-on clash with the Soviet Union," but also "will provide ex post facto support for the Soviet thesis that the crisis involved close collusion between the United States and Israel. The consequence will be the complete disappearance of U.S. political influence in the Mediterranean." The best path would probably be "publicly defining a U.S. position that is reasonable, fair and constructive, even if initially not satisfactory to any of the belligerents." The U.S. had to keep in mind "the long-range interests of the region" and not become "identified with one side alone." Brzezinski realized "Some Israeli resentment of the above posture is to be expected, but that is unavoidable unless the United States wishes to become fully identified with it." $" 84$

But the events (and years) leading up to war in 1967 - along with the war itself - had undermined the U.S. policy of evenhandedness. Hugh Smythe, the first African-American U.S.

\footnotetext{
${ }^{83}$ Read to Bundy, "An Approach to Political Settlement in the Near East," 8 June 1967, NSF, NSCH, Box 19, Middle East Crisis, Volume VII, Appendix I(4)-J, LBJL.

${ }^{84}$ Zbigniew Brzezinski, "The Middle Eastern Crisis: The U.S. Should Take an Explicit Stand," 14 June 1967, NSF, NSCH, Box 19, Middle East Crisis, Volume VII, Appendix I(4)-J, LBJL.
} 
ambassador to the Middle East, cabled from Syria, "U.S. 'evenhanded' ME policy is viewed by Arabs as fraud ... Our Arab friends have pleaded that we simply take our 'even-hand' off." According to Smythe, "My view of situation, perhaps oversimplified, is that U.S. reaping full harvest 20 year area policy which has regarded Israel as fulcrum, highest priority interest. This has rankled Arabs who now feel ... determined smash U.S. influence in area (in which they expect USSR backing).” Smythe concluded, "The folly of U.S. pursuing present policy obvious without further elaboration." ${ }^{85}$ The view from the White House was similarly bleak. Hal Saunders composed a paper for Walt Rostow a few days before the war that bemoaned the impossibility of the U.S. position. According to Saunders,

For twenty years Israel has sought a special relationship - even a private security guarantee - with us. We have steadfastly refused in order to preserve our other interests in the Middle East. We argued that our policy worked to Israel's best interest too. Now we are committed to side with Israel ... In short, we have chosen sides - not with the constructive Arabs and Israel but with Israel alone against all the Arabs. Whoever is the bigger winner, we are the sure loser. If we follow our present course, we stand to lose economically ... and to suffer substantial Soviet gains. If we back away from Israel, we're a paper tiger. ${ }^{86}$

The damage to U.S.-Arab relations was severe. An intelligence memorandum stated that "the course of the present Arab-Israeli crisis has already done considerable damage to the U.S. position in the Arab world. Most Arabs believe the U.S. is the staunch ally of Israel and can in effect control its actions. ${ }^{" 87}$ Even further, "the damage to the U.S. position in the area already appears serious. During the past twenty years, a generation of Arab youth have grown to maturity under bombardment of the idea that Israel would not exist if the U.S. had not created

\footnotetext{
${ }^{85}$ Telegram from the Embassy in Syria to the Department of State, 1 June 1967, FRUS, 1964-1968, Volume XIX, Arab-Israeli Crisis and War, 1967, Document 117.

${ }^{86}$ Memorandum by Harold Saunders of the National Security Council Staff to the President's Special Assistant (Rostow), 31 May 1967, FRU.S., 1964-1968, Volume XIX, Arab-Israeli Crisis and War, 1967, Document 114.

${ }^{87}$ Memorandum from the Board of National Estimates to Director of Central Intelligence Helms, 1 June 1967, FRU.S., 1964-1968, Volume XIX, Arab-Israeli Crisis and War, 1967, Document 126.
} 
it. ${ }^{88}$ Israeli General Meir Amit told Secretary of Defense Robert McNamara the U.S. "is already damned in the eyes of Arabs no matter what they do." ${ }^{89}$ The Lebanese Foreign Minister Hakim told Eugene Rostow that the "Arab-American friendship might be one of first victims of 'Israeli aggression." "He went on to say that Arabs believe the only reason the U.S. government remained non-belligerent was because Israel was doing well. ${ }^{90}$ The U.S. embassy in Morocco cabled on 10 June that King Hassan of Morocco similarly believed, "To the average Arab there is no doubt that we would by this time be militarily involved on Israel's side if she were being attacked by Arabs as she is now attacking them" and that the absence of a strong public statement in favor of an Israeli withdrawal "is being construed as proof that our often stated commitment to territorial integrity of Near East states works in only one direction." ${ }^{91}$ During the course of the war several Arab countries - including Syria, Egypt, and Iraq - broke diplomatic relations with the U.S., and Arab oil-producing states unsheathed the "oil weapon" against the U.S. and Britain.

After a quick, decisive victory, Israel remained in the "occupied territories" - Sinai Peninsula, Gaza Strip, West Bank of the Jordan River, Golan Heights, and all of Jerusalem. Johnson and Israeli officials agreed that withdrawal should happen only after mutually-agreed upon formal peace treaties were in place, essentially revoking Eisenhower's policy decision during the Suez crisis. According to Special Counsel to President Johnson, Harry C. McPherson, who was in Tel Aviv for the war, "There are constant references and comparisons to 1956. The

\footnotetext{
${ }^{88}$ Intelligence Memorandum Prepared in the Central Intelligence Agency, 3 June 1967, FRUS, 1964-1968, Volume XIX, Arab-Israeli Crisis and War, 1967, Document 143.

${ }^{89}$ Memorandum for the Record, 1 June 1967, FRUS, 1964-1968, Volume XIX, Arab-Israeli Crisis and War, 1967, Document 124.

${ }^{90}$ Telegram from the Department of State to the Embassy in Lebanon, 7 June 1967, FRUS, 1964-1968, Volume XIX, Arab-Israeli Crisis and War, 1967, Document 177.

${ }^{91}$ Telegram from the Embassy in Morocco to the Department of State, 10 June 1967, FRUS, 1964-1968, Volume XIX, Arab-Israeli Crisis and War, 1967, Document 248.
} 
Israelis do not intend to repeat the same scenario - to withdraw within their boundaries with only paper guarantees that fall apart at the touch of Arab hands. We would have to push them back by military force, in my opinion, to accomplish a repeat of 1956; the cut-off of aid would not do it." 92 On the domestic front, Johnson was certain to face strong pressures from the American Jewish community. David Ginsberg, the long-time advisor to the American Jewish community, sent McGeorge Bundy a memo intended for the Vice President that states, "Here I'll add a word of my own: what was done particularly in 1956 and 1957 but since then as well, from the viewpoint of U.S. interests alone, was appalling." Ginsberg also warned the White House, "What the Administration is saying and doing now is being watched carefully not only by the Jewish community, but by others who should be and have been close to the Administration and whose support - and advice - we need, have had, and should have again."93 While a member of the Senate, Johnson had opposed Eisenhower's policy of forcing Israel to withdraw from Arab territories during the Suez crisis without guarantees of peace. ${ }^{94}$ Rather than pressure Israel to withdraw, Johnson released his "Five Principles" for peace on 19 June: the right to national life, justice for the refugees, free maritime passage, limits on the arms race, and political independence and territorial integrity for all. ${ }^{95}$ The last of the five principles linked territorial withdrawal with formal peace for Israel, a condition that became a central element of UN Resolution 242, and framed future peace-making efforts.

\footnotetext{
${ }^{92}$ Harry C. McPherson, Jr., "For the President," 11 June 1967, NSF, NSCH, Box 18, Middle East Crisis, LBJL.

${ }^{93}$ Ginsberg to Bundy, Memorandum for the Vice President, 17 June 1967, NSF, NSCH, Box 19, Middle East Crisis, Volume VII, Appendix I(4)-J, LBJL.

${ }^{94}$ Quandt, 44.

95 Ibid., 45.
} 
The 1967 Arab-Israeli war, along with the weeks before and after the war, represents a watershed moment in the history of U.S.-Middle East relations. Regardless of the Soviet role in the outbreak of hostilities, the war concretized the U.S.-Israel special relationship, strained American relations with the Arab world, and redefined the nature of the conflict and peace process. Following the war, as Quandt and Smith astutely observe, American foreign policy in the Middle East changed course. Johnson, unlike Eisenhower, would not force an Israeli withdrawal until formal peace agreements had been concluded. This particular American position - support for Israeli occupation of lands taken during the war until Arab states agreed to bilateral peace agreements with Israel - has been the basis for American involvement in the Arab-Israeli peace process ever since.

Smith and Quandt reasonably frame the shift in U.S. policy by referencing Johnson's Five Principles of 19 June and UN Resolution 242 several months later, which established the diplomatic and political framework for the peace process. But these markers of policy were the result of an evolution of U.S. policy away from an evenhanded position staked out by the Republican Eisenhower to a special relationship with Israel that was advanced by consecutive Democratic presidencies. This shift in policy was rapidly accelerated by the war, followed by postwar diplomacy that firmly established the new American position. The U.S. and Israel had already developed an informal alliance by way of domestic politics - the state of Israel had many friends in Congress, the White House, and the American public. But the closeness of the American-Israeli relationship had been downplayed by American officials to avoid upsetting Arab states. In other words, the foundations for this shift in policy had been quietly established prior to the war, but the war and diplomatic aftermath brought this growing alliance out into the open. Although the Kremlin, in the weeks before 5 June, could not have foreseen the outcome of 
a Middle East war, Soviet officials may have foreseen how war could expose a U.S.-Israel special relationship, and consequently jeopardize American relations with Arab states. Such an obvious outcome would have been hard to miss.

Following the 1967 war, the Soviet Union secured a much stronger position in the Middle East. The Soviet military gained access to air bases and coastal facilities in the region, both for military and intelligence purposes, while Soviet munitions and advisers poured into Syria and Egypt. Moreover, Moscow emerged as a superpower willing to stand up to the United States in the Middle East, serving as an advocate and diplomatic representative for the Arab cause. ${ }^{96}$

Until historians have more access to significant, high-level primary sources regarding Soviet foreign policy, the role of the Soviet Union in the outbreak of hostilities remains unclear. Although Soviet officials claimed they did not want a war in the Middle East, Soviet behavior seems to tell a different story. Soviet misinformation about Israeli troop movements and plans to attack Egypt and Syria forced Nasser to take action in order to save face with the Arab community. The Soviet propaganda machine repeatedly stressed a U.S.-Israel alliance, when potentially the entire war could have been avoided through diplomacy. But the Soviet Union wanted no part of discussions aimed at keeping peace.

In trying to understand the origins of the 1967 Arab-Israeli war, perhaps one lesson to be learned from blending the historiographies of American and Soviet foreign policy is that Soviet leadership sought to redefine superpower politics in the Middle East by letting the combustible situation explode into war, undermining U.S. interests in the region and advancing Soviet policy by other means. Suri recognizes that "the White House gave too little attention to the emerging crisis in the Middle East, and the provocative Soviet role in the crisis, before June 1967. President Johnson, in particular, ignored Moscow's maneuvers in this region as he pursued

\footnotetext{
${ }^{96}$ Golan, 16.
} 
Soviet assistance in Southeast Asia and détente in Europe." ${ }^{97}$ However scholarship has overlooked the lengths to which Western powers sought to engage the Soviet Union in a productive dialogue to prevent the outbreak of war - all to no avail.

Although this dissertation will not focus on Soviet foreign policy motives in the Middle East, it is important to note that United States-Soviet tension over the Middle East is an important framework for understanding the various Middle East conflicts in the late 1960s and 1970s. The basis of United States-Soviet tension was that both sides wanted to extend their influence to the Middle East at the expense of the other.

${ }^{97}$ Suri, 121. 


\section{Chapter 3: \\ Phantom Peace: Henry "Scoop" Jackson, J. William Fulbright, and Military Sales to Israel}

Although every change in Presidential administration produces a new foreign policy, of course, when Richard M. Nixon entered the White House he introduced some very new U.S. foreign policies.

Many Presidents enter office wanting to focus on domestic issues. Nixon, however, was a foreign policy President from day one. He introduced the Nixon Doctrine and burden-sharing by regional allies. He introduced Détente with the major communist powers, USSR and People's Republic of China. Since the Soviets had "caught up" in the area of nuclear weapons production, it behooved the United States to ease tensions with them.

During Nixon's first term as President, the United States Congress played an important role in securing larger military aid packages for Israel, especially F-4 Phantom jets. With supersonic speed, radar-guided missiles, and the potential to deliver a nuclear weapon, the Phantoms promised to swing the balance of power in the Middle East even farther in Israel's direction. ${ }^{1}$ Israeli airpower had been the decisive factor in the 1967 Arab-Israeli war, and the War of Attrition between Israel and Egypt (which ended in August 1970) showed that the sophisticated Phantoms were necessary to combat Soviet-supplied, Egyptian artillery along the Suez Canal Zone. ${ }^{2}$

Richard Nixon's first term witnessed a significant increase in military assistance to Israel, which cannot be understood without looking at congressional, and in particular, Senate politics. This chapter focuses on the battle between Henry "Scoop" Jackson (D-WA) and J. William

\footnotetext{
${ }^{1}$ Douglas Little, American Orientalism: The United States and the Middle East since 1945, Third Edition (Chapel Hill: University of North Carolina Press, 2008), 98.

${ }^{2}$ For a discussion about the importance of Phantoms to Middle East warfare during this time, see Ronald Drucker, "McDonnell F-4 Phantom: Essential Aircraft in the Air Warfare in the Middle East," HistoryNet, June 12, 2006, retrieved August 18, 2015, http://www.historynet.com/mcdonnell-f-4-phantom-essential-aircraft-in-the-air-warfarein-the-middle-east.htm.
} 
Fulbright (D-AR) over U.S. foreign policy in the Middle East, and specifically about military sales to Israel. ${ }^{3}$ Jackson, who ran for President in 1972 and 1976, and Fulbright, the longesttenured Chair of the Senate Foreign Relations Committee, staked out very different positions for the proper relationship between the United States and Israel. Jackson viewed the Arab-Israeli conflict through the lens of the Cold War and wanted the President to authorize more military credit sales to Israel to match the growing Soviet presence in the region. A presidential hopeful for the 1972 election, Jackson planned to use the issue to challenge détente, bolster his conservative position in foreign policy, and generate goodwill in the American Jewish community to support his upcoming bid. In doing so, he demonstrated that a Senator can be just as apt to use the State of Israel to his advantage as the reverse in that relationship, something of a counter-point to the argument made by John Mearshimer and Stephen Walt regarding the proIsrael lobby. ${ }^{4}$ Fulbright, on the other hand, advocated for more cooperation with the Soviet Union in the hopes of facilitating a comprehensive peace agreement through the United Nations; he regarded increased military sales as a threat to a potential peace agreement. A discussion about the Jackson-Fulbright conflict not only encourages broader thinking about congressional participation in U.S. foreign policy in the Middle East; it also exposes significant political fault lines which would complicate the making of U.S. policy toward Israel for years to come.

Historians have largely overlooked Congress and U.S. foreign policy in the Middle East. Robert David Johnson avoids discussion of U.S.-Middle East relations in his outstanding study, Congress and the Cold War. According to Johnson, "Policy toward certain regions, especially the Middle East, largely fell outside of the Cold War framework because of the Arab-Israeli

\footnotetext{
${ }^{3}$ The standard biographies for the two influential senators are Robert Gordon Kaufman, Henry M. Jackson: A Life in Politics (Seattle: University of Washington Press, 2000), and Randall Bennett Woods, Fulbright: A Biography (Cambridge: Cambridge University Press, 1995).

${ }^{4}$ John J. Mearshimer and Stephen M. Walt, The Israel Lobby and U.S. Foreign Policy (New York: Farrar, Straus and Giroux, 2007).
} 
conflict, the role of oil diplomacy, the activities of the Israeli lobby, and the emergence of terrorism in the mid-1970s." However, a number of scholars have produced insightful treatments about the Nixon administration's approach to the Arab-Israeli peace process. Craig Daigle explores how the Middle East contributed to and limited détente between the U.S. and Soviet Union during Nixon's first term. ${ }^{6}$ Steven Spiegel charts the influence of U.S. domestic politics on presidential policies in the Middle East from Truman to Carter. ${ }^{7}$ David Korn examines peace discussions and great power diplomacy during the period beginning with the aftermath of the 1967 war through the end of the War of Attrition. ${ }^{8}$ Other scholars have also chosen to study the President and the peace process. ${ }^{9}$

Instead of looking at the Arab-Israeli peace process through the executive branch, as other scholars have done, this chapter discusses the issue of military sales to Israel seen primarily through the legislative branch using the often-overlooked collections of important congressmen to make its case. That does not mean to suggest, however, that military sales and peace discussions existed in separate vacuums. Rather, the two have shared something of a symbiotic relationship with each impacting discussions about the other. One reason Nixon sought to limit military sales was his fear that if Israel was too strong it would resist peace negotiations. However Israel fit perfectly into the President' plan to send arms and provide a nuclear umbrella

\footnotetext{
${ }^{5}$ Robert David Johnson, Congress and the Cold War (Cambridge: Cambridge University Press, 2006), xxv. See also, Marvin C. Feuerwerger, Congress and Israel: Foreign Aid Decision-Making in the House of Representatives, 1969-1976 (Westport, CT: Praeger, 1979), and Mohamed Rabie, The Politics of Foreign Aid: U.S. Foreign Assistance and Aid to Israel (New York: Praeger, 1988).

${ }^{6}$ Craig Daigle, The Limits of Détente: The United States, the Soviet Union, and the Arab-Israeli Conflict, 1969-1973 (New Haven: Yale University Press, 2012).

${ }^{7}$ Steven L. Spiegel, The Other Arab-Israeli Conflict: Making America's Middle East Policy, from Truman to Reagan (Chicago: University of Chicago Press, 1985).

${ }^{8}$ David Korn, Stalemate: The War of Attrition and Great Power Diplomacy in the Middle East, 1967-1970 (Boulder: Westview, 1992).

${ }^{9}$ Boaz Vanetik and Zaki Shalom, The Nixon Administration and the Middle East Peace Process, 1969-1973 (Chicago: Sussex Academic Press, 2013), and William B. Quandt, Peace Process: American Diplomacy and the Arab-Israeli Conflict since 1967, Third Edition (Washington D.C.: Brookings Institution Press, 2005).
} 
for regional allies, part of the Nixon Doctrine. Therefore, the two discussions speak well to each other.

The U.S. Congress played a central role in the development of the special relationship between the United States and Israel during Nixon's first term. Historians of both U.S. and Israeli foreign policy have debated the origins and development of the special relationship, which is an informal alliance built upon cultural factors, political support for Israel, and foreign assistance that increasingly took the form of weapons sales. Peter Hahn points out that the special relationship had ups-and-downs during the Harry Truman and Dwight Eisenhower presidencies, and stresses the persistent conflict in U.S.-Israel relations. ${ }^{10}$ Douglas Little contends that the special relationship emerged during the thaw in U.S.-Israel relations at the end of Eisenhower's presidency, marked by the President's decision to sell radar equipment to Israel, and became operative policy with the Lyndon Johnson administration. ${ }^{11}$ Abraham Ben-Zvi, like Little, sees Eisenhower's second term as the beginnings of the alliance, which for Ben-Zvi ultimately blossomed when Israel demonstrated its strategic value in protecting King Hussein during Black September in 1970. ${ }^{12}$ David Schoenbaum discusses the gradual evolution of the relationship, especially the importance of the Kennedy and Johnson presidencies, and also regards Black September as a crucial event. ${ }^{13}$ Warren Bass argues that the Kennedy administration "constitutes the pivotal presidency in U.S.-Israel relations," situated between the

\footnotetext{
${ }^{10}$ Peter L. Hahn, Caught in the Middle East: U.S. Policy toward the Arab-Israeli Conflict, 1945-1961 (Chapel Hill: University of North Carolina Press, 2004).

${ }^{11}$ Douglas Little, "The Making of a Special Relationship: The United States and Israel, 1957-68," International Journal of Middle East Studies, Vol. 25, No. 4 (November 1993), 563-585; Little, "The Making of a Special Relationship" in American Orientalism, 77-115.

${ }^{12}$ Abraham Ben-Zvi, The Origins of the American-Israeli Alliance: The Jordanian Factor (New York: Routledge, 2007).

${ }^{13}$ David Schoenbaum, The United States and the State of Israel (Oxford: Oxford University Press, 1993), 173.
} 
rocky years of Eisenhower and the warm relations during the Johnson years. ${ }^{14}$ Bar-Siman-Tov identifies the 1967 Arab-Israeli war as "the watershed in establishing the special relationship", and goes on to argue that the 1973 Arab-Israeli war, along with the massive U.S. airlift for Israel, concretized the special relationship. ${ }^{15}$ In his recent book, Dennis Ross also highlights the U.S. resupply of Israel during the 1973 war. According to Ross, Nixon's decision had more to do with "concerns that Soviet weapons could not be seen to defeat American weapons than with any special relationship that existed between our two countries." 16

Yet these works focus on presidential policies, and miss the ways in which Congress challenged the President and sought to mold U.S. foreign relations with the region. As shown below, President Nixon was unprepared to arm Israel to the extent desired by Scoop Jackson and other congressional members. Moreover, Congress continually pushed the Administration, especially Secretary of State William Rogers, to not pressure Israel into abandoning territory taken during the 1967 war. The special relationship became truly special during Nixon's first term, based on unwavering political support for Israel and a vastly expanded military sales program, due in large part to the efforts of legislators, especially from within the Senate.

Some scholars have considered the Nixon Presidency in terms of the Imperial Presidency - basically, that Nixon ambitiously sought to consolidate all power in the White House and bypass congressional participation in foreign policy. The most recognizable work came in 1973 from Arthur Schlesinger, Jr., The Imperial Presidency. However prior to Schlesinger's seminal work, William Fulbright bemoaned the absence of Senate participation in making wars or treaties

\footnotetext{
${ }^{14}$ Warren Bass, Support Any Friend: Kennedy's Middle East and the Making of the U.S.-Israel Alliance (Oxford: Oxford University Press, 2003), 3.

${ }^{15}$ Yaacov Bar-Siman-Tov, “The United States and Israel since 1948: A 'Special Relationship'?” Diplomatic History, Vol. 22, Issue 2 (Spring 1998), 231-262.

${ }^{16}$ Dennis Ross, Doomed to Succeed: The U.S.-Israel Relationship from Truman to Obama (New York: Farrar, Straus and Giroux, 2015), 3.
} 
in The Arrogance of Power, and then more forcefully criticized the Imperial Presidency in The Crippled Giant, published a year before Schlesinger's study. ${ }^{17}$ Other fine academic treatments exist, especially from James L. Sundquist, former speech-writer for Harry Truman and Senior Fellow Emeritus at the Brookings Institute, and Louis Fisher, who worked for several decades at the Library of Congress as Senior Specialist for the Separation of Powers, as well as Constitutional Law. ${ }^{18}$ Renewed interest in the topic came with George W. Bush's presidency, especially regarding the 2003 war in Iraq and the influential role of neoconservatives.

Schlesinger again led the charge with War and the American Presidency, and he was joined by scholars whose works questioned the prudence or legal foundations of decision-making in the Bush White House. ${ }^{19}$ Others explore the career of Bush's Vice President, Dick Cheney, as well as Barack Obama's ability to deploy forces in parts of Africa, Asia, and the Middle East. ${ }^{20}$ However such studies focus almost exclusively (and understandably) on the Vietnam War and the gradual restriction of presidential power, and in doing so overlook congressional assertiveness in the area of U.S.-Israel relations. As opposed to the Far East, Congress sought to expand, rather than restrict, the President's power to conduct foreign relations with the Near

\footnotetext{
${ }^{17}$ Arthur Schlesinger, Jr., The Imperial Presidency (Boston: Mariner Books, 1973); J. William Fulbright, The Arrogance of Power (New York: Random House, 1966), 44-65; and J. William Fulbright, The Crippled Giant: American Foreign Policy and Its Domestic Consequences (New York: Vintage Books, 1972), 177-242.

${ }^{18}$ James L. Sundquist, The Decline and Resurgence of Congress (Washington D.C.: Brookings Institution Press, 1981); Louis Fisher, President and Congress: Power and Policy (New York: Free Press, 1972); Louis Fisher, The Politics of Shared Power: Congress and the Executive, Fourth Edition (College Station: Texas A\&M University Press, 1998); and Louis Fisher, Constitutional Conflicts Between Congress and the President, Fifth Edition (Lawrence: University of Kansas Press, 2007).

${ }^{19}$ Arthur Schlesinger, Jr., War and the American Presidency (New York: W. W. Norton, 2004); Andrew Rudalevige, New Imperial Presidency: Renewing Presidential Power after Watergate (Ann Arbor: University of Michigan Press, 2006); Charlie Savage, Takeover: The Return of the Imperial Presidency and the Subversion of American Democracy (New York: Back Bay Books, 2007); Peter Irons, War Powers: How the Imperial Presidency Hijacked the Constitution (New York: Metropolitan Books, 2005); and James R. Silkenat and Mark R. Shulman, eds., The Imperial Presidency and the Consequences of 9/11: Lawyers React to the Global War on Terrorism (Westport: Praeger, 2007).

${ }^{20}$ Bruce P. Montgomery, Richard B. Cheney and the Rise of the Imperial Vice Presidency (Westport: Praeger, 2009); Ryan C. Hendrickson, Obama at War: Congress and the Imperial Presidency (Lexington: University Press of Kentucky, 2015).
} 
East, especially in the area of weapons sales. For example, the Senate repealed the Tonkin Gulf Resolution on July 24, 1970, and just over a month later passed the Jackson Amendment on September 1, which empowered Nixon to sell up to $\$ 500$ million of weaponry to Israel on favorable credit.

Thus, the narrative of the Imperial President vs. Congress requires some adjustment. Congressional assertiveness was not just a constitutional effort to limit Presidential power in foreign affairs, but also a practical effort to inform and redirect U.S. foreign policy. In other words, Congress was not necessarily upset with the extent of Presidential power, but rather with how the President wielded that power, and thus Congress sought to influence policy as much as restore better constitutional balance. Rather than presidential power subverting democracy during the Nixon years - an argument central to the narrative of the Imperial Presidency - strong congressional support for Israel also reflected broad, popular support for Israel, and in that way advanced, more than inhibited, democratic government.

Finally, the debates about military aid for Israel revealed a developing alliance between U.S. conservatives and the State of Israel that would continue to impact U.S. foreign policy for decades to follow, in particular with regard to the peace process. ${ }^{21}$ Israel had enjoyed bipartisan support in the U.S. from the time of the state's modern creation in 1948. But around 1970, support for Israel reflected conservative, rather than liberal tendencies. Republicans, conservative Democrats, and Cold War hawks like Jackson advanced the congressional critique of Nixon's foreign policy, putting the Administration and liberals on the defensive.

Conservatives disagreed with détente and aimed to continue the global war against communism,

\footnotetext{
${ }^{21}$ Noam Kochavi, Nixon and Israel: Forging a Conservative Partnership (Albany: State University of New York Press, 2009).
} 
which included substantial military aid packages, while liberals became more interested in human rights, nuclear non-proliferation, and reduced defense spending.

Importantly, the perceived interests of U.S. conservatives and the state of Israel started to align. Both sides argued that a strong Israel was important for reasons of Cold War national security, and to achieve a lasting peace in the Middle East required large-scale military sales to Israel, including Phantoms. For Israel, the United States could replace France as its primary weapons supplier, and for U.S. conservatives, especially in the context of the Vietnam War, Israel could become the new centerpiece of U.S. Cold War foreign policy. As the Cold War consensus fell apart, and as South Vietnam's position became increasingly untenable, conservative members of Congress shifted some of their focus from Southeast Asia to the Middle East, where they joined many liberals in a revamped, bipartisan support for Israel that helped the special relationship take a giant step forward.

The political aftermath of the June 1967 Arab-Israeli war set the stage for future conflict. On September 1, 1967, the heads of 13 Arab states released the Khartoum Resolution, which famously declared the three 'No's' - no peace with Israel, no recognition of Israel, and no negotiations with Israel. After capturing the Sinai Peninsula, Golan Heights, West Bank, Gaza Strip, and all of Jerusalem, Israel was determined to not withdraw to previous lines without guarantees of peace - precisely what had happened with the Suez crisis only ten years before. Moreover, Israel enjoyed a decisive military advantage and was understandably reluctant to return the occupied territories to people who publicly refused to make peace with Israel. After months of negotiating at the U.N., the Security Council passed Resolution 242 that established the "land for peace" framework as the means for resolving the Arab-Israeli conflict. U.N. 
Secretary General U Thant appointed Gunnar Jarring, a Swedish diplomat, to negotiate the implementation of 242; however, the vague wording of the resolution, along with the fact that neither side appeared willing to take risks to find peace, ensured that Jarring's efforts would come to naught.

Unsatisfied with the status quo, Egyptian President Gamal Abdel Nasser launched a "War of Attrition" against Israel beginning in March 1969. Using Soviet weaponry, Egyptian forces began a heavy bombardment of Israeli forces along the Suez Canal zone. ${ }^{22}$ Israel was largely successful in repelling attacks and offered some of its own, conducting deep raids into Egyptian territory during the first few months of 1970 , thanks to U.S.-made Phantoms. ${ }^{23}$ The first delivery of Phantoms, which arrived in September 1969, extended Israel's strategic reach and abruptly changed the balance of power. Previously, Israel had launched only a few commando raids into Egypt. But by January 1970 the Phantoms allowed Israel to fly deep bombing raids into Egyptian territory, including the Cairo area. Egypt responded by asking Moscow for greater Soviet involvement, which in turn increased U.S. concern. ${ }^{24}$

During the War of Attrition, Secretary of State William Rogers tried to assist Jarring and restart the stalled peace process by offering his own plan. The "Rogers Plan," which was announced on December 9, 1969, focused on an Israel-Egypt agreement as a first step in the peace process. Israel was to withdraw from Egyptian territory occupied in 1967, in return for a peace agreement with Egypt that included safe passage of Israeli shipping through the Suez Canal. ${ }^{25}$ However, the Rogers Plan met a strong rejection. As William Quandt writes in Peace

\footnotetext{
${ }^{22}$ Daigle, 39.

${ }^{23}$ Ibid., 55-56, 83-89.

${ }^{24}$ Daigle, 83-98; Schoenbaum, 173.

${ }^{25}$ Quandt, 67.
} 
Process, "The Israeli and Soviet rejections of the Rogers Plan, and Egypt's nonacceptance, put a sudden end to the first Middle East initiative of the Nixon administration."26

The War of Attrition entered a new phase in early 1970 when the Soviet Union secretly increased its military involvement in Egypt with Operation Kavkas. ${ }^{27}$ In response to Israeli air raids, and using the situation to its geopolitical advantage, the Kremlin substantially increased its military presence in Egypt by sending more than ten thousand "instructors" and "advisers", along with numerous sites of the new SA-3 surface-to-air missile systems, which were quietly installed along the Suez Canal. Additionally, the Soviet navy strengthened its presence in the Mediterranean and Soviet pilots became actively engaged in the Egyptian air defense. ${ }^{28}$ As Dmitry Adamsky points out, the Soviet decision to become militarily engaged in the Middle East surprised both U.S. and Israeli intelligence communities. ${ }^{29}$ Moreover, Adamsky argues in a later article that while the Israeli Phantom raids played a role in the Soviet decision to increase its involvement, that decision had been made in principle several months earlier based on Soviet projections of U.S. and NATO strategic capabilities from the Mediterranean region. As the Egyptian position deteriorated vis-à-vis Israel, Soviet leadership decided to significantly increase its military presence in the region. ${ }^{30}$ Soviet involvement reached a new level on April 18, when Soviet pilots chased down two Israeli jets that had been conducting reconnaissance inside Egypt. The Israeli jets were not attacked, but the Soviet willingness to directly challenge Israeli planes and by extension the United States - brought with it the possibility for superpower confrontation in the Middle East.

\footnotetext{
26 Ibid., 68.

${ }^{27}$ Daigle, 98-105.

${ }^{28}$ Daigle, 87.

${ }^{29}$ Dima P. Adamsky, "Disregarding the Bear: How U.S. Intelligence Failed to Estimate the Soviet Intervention in the Egyptian-Israeli War of Attrition," Journal of Strategic Studies, Vol. 28, Issue 5 (2005), 803-831.

${ }^{30}$ Dima P. Adamsky, “'Zero-Hour for the Bears': Inquiring into the Soviet Decision to Intervene in the EgyptianIsraeli War of Attrition, 1969-70," Cold War History, Vol. 6, No. 1 (February 2006), 113-136.
} 
The buildup of Soviet arms in Egypt amplified Israel's requests for more Phantom jets, part an ongoing trend of supplying Israel with weaponry. U.S. Presidents had gradually agreed to sell weaponry to Israel, part of the evolution of the special relationship, but refrained from becoming Israel's primary weapons supplier. Eisenhower declined to sell Hawk antiaircraft missile systems, but agreed to sell radar equipment; a few years later John F. Kennedy approved the sale of eight Hawk systems to Israel. Lyndon Johnson first offered offensive weapons in 1965 with the sale of 210 M-48 tanks, and he eventually agreed to sell 48 A-4 Skyhawk jets in March 1966. ${ }^{31}$ David Schoenbaum, in particular, offers a fine discussion about weapons sales and more general foreign aid to Israel during the Kennedy and Johnson presidencies. ${ }^{32}$

During 1968, pressure mounted on LBJ to have the U.S. fill the void left by France and become Israel's primary weapons supplier. As Gadi Heimann explains, the France-Israel relationship had always been a rocky one because Israel refused to act as a client state, and limit its security policy in order to advance key French interests in the region. ${ }^{33}$ The relationship cooled considerably after Charles de Gaulle warned Israel not to attack in June 1967. Along with the 1967 war, decolonization in North Africa and concerns about oil supplies led to a readjustment of French policy in the region, which included an embargo on weapons to Israel. Johnson feared an escalation of the arms race in the Middle East and was concerned about adequate weapons supplies to fight the war in Vietnam, and therefore declined to sell Phantom jets to Israel.

\footnotetext{
${ }^{31}$ American Orientalism, 93-103; Zach Levey, “The United States' Skyhawk Sale to Israel, 1966: Strategic Exigencies of an Arms Deal," Diplomatic History, Vol. 28, Issue 2 (April 2004), 255-276.

32 Schoenbaum, 132-153.

${ }^{33}$ Gadi Heimann, "From Friendship to Patronage: France-Israel Relations, 1958-1967," Diplomacy \& Statecraft, Vol. 21, Issue 2 (June 2010), 240-258; Gadi Heimann, 'From 'Irresponsible' to 'Immoral': The Shifts in de Gaulle's Perception of Israel and the Jews,” Journal of Contemporary History, Vol. 46, No. 4 (October 2011), 897-919.
} 
But Congress challenged the President, and with the Soviet invasion of Czechoslovakia Johnson finally agreed to sell 50 Phantoms in December $1968 .{ }^{34}$ Several efforts were made by Congress to force military sales through legislation. In June, Senator Stuart Symington (D-MO) "threatened to kill the military sales bill if the president did not deliver the Phantoms." ${ }^{35}$ The following month, Rep. Lester Wolff (D-NY) offered an amendment to the Foreign Assistance Act of 1968 that called on the President to sell Israel 50 Phantoms and replace losses suffered in the 1967 war. But the amendment was opposed because, by trying to force the President to sell the Phantoms, Congress was overstepping its constitutional right. ${ }^{36} \mathrm{~A}$ less powerful amendment, which expressed the sense of the Congress that the President should authorize Phantom sales to Israel, cleared both the Senate and House. Johnson's position softened with the Soviet invasion of Czechoslovakia in August, and when he signed the Foreign Assistance Act in October, he "announced that he had taken note of the section concerning the sale of airplanes to Israel, and was asking the Secretary of State to initiate negotiations with Israel."${ }^{37}$

Assistant Secretary of Defense Paul Warnke rightly recognized that the Johnson administration wanted to avoid becoming Israel's arms supplier, but the refusal of the Europeans, and in particular the French, forced the Administration's hand. "We will henceforth become the principal arms supplier to Israel," said Warnke, “involving us even more intimately with Israel’s security situation and involving more directly the security of the United States.” In December, President Johnson authorized the sale of 50 Phantoms, with 16 to be delivered in late 1969 and another 34 in $1970 .{ }^{38}$

\footnotetext{
${ }^{34}$ Mitchell Bard, The Water's Edge and Beyond: Defining the Limits to Domestic Influence on United States Middle East Policy (New Brunswick, NJ: Transaction Publishers, 1991), 189-211; David Rodman, "Phantom Fracas: The 1968 American Sale of F-4 Aircraft to Israel," Middle Eastern Studies, Vol. 40, No. 6 (November 2004), 130-144.

${ }^{35}$ Bard, 201.

${ }^{36}$ Ibid., 202.

37 Ibid., 204.

${ }^{38}$ Ibid.
} 
Israel requested an additional 125 planes (100 Skyhawks and 25 Phantoms) in September 1969, but President Nixon declined to meet the new request. Nixon declined the same request again in March 1970, even after it became known that Moscow had increased its military involvement in Egypt. Nixon and Rogers believed that the existing order of 50 Phantoms was enough to keep the military balance of power in Israel's favor; however, the Administration reserved the right to sell new aircraft if the situation changed significantly. ${ }^{39}$ Although the Soviet Union had escalated the arms race in the region, the Administration viewed the weaponry as defensive in nature and wanted to avoid a further escalation unless it appeared offensive weapons were being employed. ${ }^{40}$ Complicating the situation even further, France agreed to sell to Libya more than 100 Mirage jets in early January, some of which had been earmarked for Israel. ${ }^{41}$ On February 24, the day before French President George Pompidou spoke to Congress, Representative Thomas Rees (D-CA) submitted a joint "Declaration of Concern to President Pompidou on French Middle East Policy", that communicated "dismay" over the French decision to sell 100 Mirage jets to Libya. ${ }^{42}$

Nixon was reluctant to sell the Phantom jets to Israel for several reasons. Like the presidents before him, Nixon feared that Israel was secretly becoming a nuclear power and did not want to provide a vehicle to deliver such weapons. He also resented the influence of proIsrael forces in Washington and hoped peace discussions in the Middle East could advance détente with the Soviet Union. ${ }^{43}$ Additionally, Nixon believed that U.S. foreign policy in the region had been too biased in favor of Israel. He told Rogers, "I believe that an even-handed

\footnotetext{
39 "Nixon's Answer to Israel: What it is and Why," New York Times, March 22, 1970, accessed online with ProQuest, January 25, 2015.

${ }^{40}$ David E. Rosenbaum, "U.S. Appears to Speed Up Plane Shipments to Israel,” New York Times, July 13, 1970, accessed online with ProQuest, January 25, 2015.

${ }^{41}$ Quandt, 71.

42116 Congressional Record [hereafter $C R$ ], $91^{\text {st }}$ Congress, $2^{\text {nd }}$ Session, 4597-4598 (February 24, 1970).

${ }^{43}$ Daigle, 16.
} 
policy is, on balance, the best one for us to pursue as far as our own interest are concerned." 44 Perhaps most important, Nixon feared that if Israel had a steady supply of Phantom jets, it would be even less inclined to work with UN special envoy Gunnar Jarring to implement UN Resolution 242. By denying further Phantom sales to Israel, Nixon hoped to cultivate better relations with the USSR and Arab states while maintaining leverage with Israel. Therefore, Nixon was unreceptive to repeated calls for the sale of additional F-4s to Israel. But like Johnson, the decision to withhold Phantom sales to Israel put Nixon on a collision course with Congress.

\section{Henry "Scoop" Jackson and William Fulbright}

The Democratic Party started to split on Israel, and an emerging conservative bloc in Congress, which included conservative, hawkish Democrats along with Republicans proved able to rewrite the contours of U.S.-Israel relations. That split was best exemplified by the contentious relations between Henry “Scoop” Jackson and James William Fulbright.

Jackson and Fulbright were senatorial colleagues, but the two were not friends. "Indeed," says Jackson biographer Robert Kaufman, "the two men detested one another." 45 According to Helen Jackson, Henry's wife, "The only thing that Scoop and Senator Fulbright agreed on was where to buy wing-tip shoes in London." ${ }^{46}$ Fulbright referred to Jackson as "the congressional spokesman for the military-industrial complex," while Jackson regarded Fulbright as "arrogant and a hypocrite" - someone who claimed to have sympathies for people abroad who were hurt by the "arrogance of American power, yet voted for the Southern Manifesto of 1956 and against every major piece of civil rights legislation that came before the Senate." ${ }^{\prime 47}$ After Fulbright lost

\footnotetext{
${ }^{44}$ Ibid., 17.

${ }^{45}$ Kaufman, 176.

${ }^{46}$ Ibid.

${ }^{47}$ Ibid.
} 
the Arkansas Democratic primary to Dale Bumpers in 1974, Jackson and his staff celebrated with a case of whiskey. ${ }^{48}$

In terms of U.S. foreign policy, Jackson and Fulbright represented the different ends of the political spectrum in the Democratic Party. Jackson was a Cold War liberal who wanted nothing to do with détente and insisted on using military power to challenge the evil designs of the Soviet Union. Fulbright, on the other hand, advocated for a "new internationalism" - rooted in educational and cultural programs, reduced military spending, détente with the Soviet Union, and a more activist United Nations - to facilitate increased international understanding and a stronger position abroad. Fulbright hoped that a settlement to the Arab-Israeli crisis could be completed through the UN, which he explained in a speech on "A New Internationalism" to Yale University on April 4, 1971, as well as in his book about U.S. foreign policy, The Crippled Giant. ${ }^{49}$ Fulbright hoped to curb Presidential power, while Jackson sought to expand it.

The two had very different ideas about military sales and the Vietnam War. Jackson had long supported federal spending (especially defense spending) as a way to both contain communism and fuel the U.S. economy. Some officials, like Robert McNamara, labeled Jackson, "the Senator from Boeing" for his efforts to secure defense contracts for the giant aviation company from his home state. ${ }^{50}$ Senator George Aiken (R-VT) once remarked that "other areas benefit from government contracts, too, but not all their elected members of Congress are as ardent in their endeavors as Scoop Jackson is." ${ }^{51}$ Jackson also supported U.S. involvement in the Vietnam War until very late, and sought to counterbalance the influence of the New Left by

\footnotetext{
48 Woods, 669.

${ }^{49}$ William Fulbright, “A New Internationalism,” speech delivered to Yale University, April 4, 1971, Box 33, Series 72:10, J. William Fulbright Papers at the University of Arkansas [hereafter, JWFP]. J. William Fulbright, The Crippled Giant: American Foreign Policy and its Domestic Consequences (New York: Vintage Books, 1972).

${ }^{50}$ Kaufman, 140-45.

51 Johnson, 184.
} 
advocating a more conservative position that supported spending massive amounts of federal money on defense in order to challenge communist aggression abroad.

While Jackson sought to expand defense spending and supported U.S. military involvement in Southeast Asia, Fulbright took the opposite position. Although he actually sponsored the Tonkin Gulf Resolution that granted President Johnson virtually unlimited powers to wage a war in Vietnam, Fulbright soon withdrew his support and eventually emerged as one of the leading voices against U.S. military involvement in Vietnam. ${ }^{52}$ As head of the powerful Senate Foreign Relations Committee, Fulbright's opposition to Vietnam was much disliked by the Johnson administration.

Perhaps the greatest source of conflict between Jackson and Fulbright was about U.S. involvement in the Arab-Israeli conflict. Jackson was one of the loudest and strongest senatorial voices in support of a pro-Israeli policy. He regarded Israel as a strategic asset that could protect U.S. interests in the region and prevent, or at least limit, Soviet involvement in the Middle East. Although Fulbright continually stressed his support for Israel, he sought a more evenhanded policy in which Israel would not be given much preferential treatment. He viewed U.S. support for Israel as a liability because it soured relations with Arab states and could potentially undermine efforts to work constructively with the Soviet Union.

Jackson had supported the state of Israel from his childhood years. He recalled that his mother first instilled in him a desire to defend Jewish people. He described her as "a Christian who believed in a strong Judaism. She taught me to respect the Jews, help the Jews! It was a

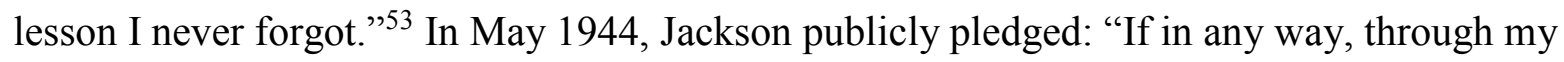
offices as a Congressman, I can forward the work of making the dream of a Jewish Homeland in

\footnotetext{
52 Johnson, 120, 161-64.

${ }^{53}$ Kaufman, 13.
} 
Palestine come true, my most earnest efforts in this great humanitarian cause can be counted on. ${ }^{.54}$ While a congressman in 1945, Jackson and seven fellow congressmen traveled to the Buchenwald concentration camp in Germany upon invitation from Dwight Eisenhower to see firsthand the horrors of Nazi atrocities. According to Kaufman, this experience, along with Jackson's philo-Semitism, help to explain the senator's strong support for the Jewish state. ${ }^{55}$ Naturally, Jackson supported Harry Truman's decision to immediately recognize the state of Israel in May 1948, and even before the Suez crisis in the fall of 1956, provoked in part by Egyptian acceptance of a Soviet aid request, Jackson argued that the Soviet Union was "stirring a witches' brew for the Free World in the Middle East." ${ }^{56}$

Fulbright supported the state of Israel, but also wanted U.S. foreign policy to reflect a balanced desire to help both Israelis and Arabs. His position reflected the Eisenhower policy towards the Middle East; however, Fulbright later parted ways with Eisenhower. He objected to the Eisenhower Doctrine, which promised military or economic aid to any Middle Eastern country to resist the spread of communism, and instead offered a substitute resolution that called for freedom of navigation through the Suez Canal, a comprehensive settlement to the ArabIsraeli conflict, and a reaffirmation of America's right to participate in regional collective security under Article 51 of the UN Charter. ${ }^{57}$

Fulbright often found himself at odds with pro-Israel lobbying groups. When JFK was considering Fulbright for Secretary of State, "American Jews and officials of the Israeli embassy bombarded members of Kennedy's entourage with entreaties to pick anybody but Fulbright." ${ }^{58}$

\footnotetext{
54 "Statement of Senator Henry M. Jackson for the Near East Report," May 24, 1972, Box 9, Folder 9/92, Accession No. 35606, Henry Jackson Papers at the University of Washington [hereafter HJP].

${ }^{55}$ Kaufman, 39.

${ }^{56}$ Ibid., 48, 103.

${ }^{57}$ Woods, 221.

${ }^{58}$ Ibid., 259.
} 
During the early 1960s, Fulbright worked with the Senate Foreign Relations Committee to investigate unregistered agents for foreign governments. The investigation included ultimately led to major revisions to the 1938 Foreign Agents Registration Act. ${ }^{59}$ As part of that investigation, Fulbright spoke at a fundraising event in 1961 that "revealed clearly that agents of the Jewish Agency and other American Zionists had violated the provisions of the Foreign Agents Registration Act. ${ }^{900}$ The committee heard testimony from Isadore Hamlin, executive director of the Jewish Agency - American Section, and his deputy, Gottlieb Hammer. The Kennedy administration managed to secure enough votes on the Senate Foreign Relations Committee to allow Hamlin and Hammer to testify in executive session, and it took a last-minute appeal from Lyndon Johnson to keep Fulbright from reading on the Senate floor the transcript of the testimonies. "Despite the fact that the dubious activities of their representatives remained secret," says Woods, "the Israeli government and American Zionists would neither forget nor forgive Fulbright ..."

The different positions of Jackson and Fulbright became more pronounced following the 1967 Arab-Israeli war. Jackson supported the Johnson administration's strong backing of Israel during and after the war. ${ }^{62} \mathrm{He}$ viewed the Arab-Israeli conflict through the prism of the Cold War; the main problem in the region was the same problem elsewhere - the Soviet Union. Fulbright, on the other hand, believed that more superpower cooperation, conducted through the United Nations, could diffuse the situation by guaranteeing Israeli shipping through the Gulf of Aqaba combined with an Israeli withdrawal from the territories occupied in the recent war. In return for an Israeli withdrawal, the Soviet Union could potentially use its influence with North

\footnotetext{
${ }^{59}$ Ibid., 311.

${ }^{60}$ Ibid., 310.

${ }^{61}$ Ibid., 311.

${ }^{62}$ Kaufman, 177.
} 
Vietnam to help end the fighting in Southeast Asia. ${ }^{63}$ But Fulbright recognized the challenges in such a course because the U.S. "role in that area has indeed been complicated by the unbalanced policy we have followed there. The truth is that the dominant influence in our domestic-political scene of the Zionist organization makes it very difficult for any Administration to be objective about the Middle East." ${ }^{\prime 4}$ The influence of pro-Israel lobbyists would continue to play a central role in Fulbright's critique of U.S. foreign policy in the region.

Although Fulbright took on the Nixon administration over Vietnam and U.S. foreign policy generally, surprisingly perhaps, he emerged as the Senate's strongest supporter of Nixon and Rogers in the Middle East. He recognized that the Administration, to his liking, was pursuing an evenhanded approach. He supported the Rogers Plan, but bemoaned "the enormous influence of the Zionists in this country," which made the Administration's task much more difficult. ${ }^{65}$ Moreover, Fulbright was irritated by the way "the subject of peace in the Middle East is one upon which American citizens are not viewed as either patriotic or unbiased unless they endorse and even embrace the policies of a single foreign government. ${ }^{" 66}$ Although he hoped to "contribute to the improvement of relations in the Middle East," Fulbright recognized that "I am, after all, a legislator, and it is not my responsibility to supplant the Ambassadors or other representatives of the Executive Branch" in matters of foreign policy. ${ }^{67} \mathrm{He}$ similarly downplayed the legislative role to a constituent, explaining that a solution to the Arab-Israeli conflict was "not a legislative matter, but an executive matter." ${ }^{38}$ Thus, regarding U.S. foreign policy in the

\footnotetext{
${ }^{63}$ Woods, 454-55.

${ }^{64}$ Fulbright to Dr. H. E. Hyder, June 14, 1967, Box 40, Series 48:15, JWFP.

${ }^{65}$ Fulbright to John Fistere, December 15, 1969, Box 40, Series 48:15, JWFP.

${ }^{66}$ Fulbright quote taken from, R.I. Brougham, Letter to the Editor, The Middle East Newsletter, Vol. IV, Nos. $1 \& 2$, March 1970, Box 40, Series 48:15, JWFP.

${ }^{67}$ Fulbright to John Fistere, December 15, 1969, Box 40, Series 48:15, JWFP.

${ }^{68}$ Fulbright to David A. Shapiro, June 13, 1967, Box 40, Series 48:15, JWFP.
} 
Middle East, Fulbright desired greater presidential assertiveness coupled with congressional acquiescence.

Jackson regarded U.S. foreign policy in the Middle East as fundamentally flawed because it failed to recognize that the Soviet Union was trying to take over the Middle East through its regional ally, Egypt. Operation Kavkas and the substantial increase in the Soviet presence in 1970 seemed to validate, to some extent, Jackson's argument. He viewed the situation as a continuation of the historical Russian drive for domination of the region for a warm-water port, and for the more recent discovery of oil supplies. Especially affected by the Cuban Missile Crisis, Jackson considered the Soviet buildup of arms in Egypt to be another attempt to undermine U.S. interests, or at least to create leverage for more favorable negotiations. Henry Kissinger, too, considered the Soviet tactics to be similar to those employed in Cuba. ${ }^{69}$ Jackson argued that the best way to achieve a settlement to the Arab-Israeli conflict was by substantially increasing military aid to Israel. Such a move would deter Soviet meddling and allow Israel "to take risks at the negotiating table." ${ }^{70}$ In that way, U.S. military aid promised to play an important role in the Arab-Israeli peace process.

\section{The Jackson Amendment, or Section 501 of the Defense Procurement Act}

The positions of Jackson and Fulbright diverged even further in the spring of 1970. In light of revelations of increased Soviet activity in Egypt, and as Nixon widened the Vietnam War by invading Cambodia, Israeli ambassador Yitzhak Rabin stirred up congressional opposition to the Administration's unwillingness to sell more Phantoms to Israel. The Nixon administration hoped to parlay a hold on Phantoms sales to Israel into closer relations with Egypt and

\footnotetext{
${ }^{69}$ Daigle, 103.

70 “Jackson Criticizes Fulbright," Washington Post, August 30, 1970, Box 252, Folder 252/9, Accession No. 35604, HJP.
} 
movement forward in the peace process. Therefore, Nixon sent Joseph Sisco to Cairo to meet with Nasser in mid-April. Nasser likely had little reason to believe that U.S.-Egypt negotiations could lead to a peace agreement with Israel, but he also realized that the appearance of movement towards peace could prevent new shipments of Phantoms to Israel. In a May 1 speech, Nasser invited the U.S. to advance a new political initiative. The following month Secretary of State Rogers responded with a "second" Rogers Plan, which called on Egypt and Israel to accept a ceasefire and end the War of Attrition. ${ }^{71}$

While the Administration tried to withhold Phantom sales as a means to create leverage for peace negotiations, Congress insisted on more Phantoms for Israel to challenge Soviet involvement in Egypt and strengthen the Israeli position for peace talks. Congress occasionally used open letters to the executive branch as a means for influencing policy, like during the fall of 1968, when 70 senators signed a letter for LBJ asking that he sell Phantom jets to Israel. ${ }^{72}$ On May 26, 1970, Jackson joined with 72 other senators in signing a letter to Secretary of State Rogers that asked the Administration to authorize the sale of 125 warplanes to Israel, the same request as September 1969, in order to restore the military balance in Israel's favor. ${ }^{73}$ Invited by Senator Abe Ribicoff (D-CT) to sign the letter, Fulbright declined. ${ }^{74}$ On June 4, the House of Representatives forwarded a similar letter with 90 signatures. ${ }^{75}$ Never one to be pressured by either Congress or pro-Israel lobbyists, Nixon again refused to meet the request.

Jackson responded by using his powerful position within the Senate Armed Services Committee to sponsor an amendment to give the President broad powers to supply Israel with

\footnotetext{
${ }^{71}$ Quandt, 72-76.

${ }^{72}$ American Orientalism, 102.

${ }^{73}$ Memorandum of Conversation, "President's Meeting with his Foreign Intelligence Advisory Board," June 5, 1970, Foreign Relations of the United States [hereafter, FRUS], 1969-76 Vol. XXIV, Middle East Region and Arabian Peninsula, 1969-1972; Jordan, September 1970, Document 23.

${ }^{74}$ Ribicoff to Fulbright, May 26, 1970, Box 40, Series 48:15, JWFP.

${ }^{75} 116 C R, 91^{\text {st }}$ Congress, $2^{\text {nd }}$ Session, 18536-18537 (June 4, 1970).
} 
military arms. The Jackson amendment, otherwise known as Section 501 of the Defense Procurement Act, was passed by the Armed Services Committee on June 17, 1970. Linking a strong Israel to Cold War geopolitics, the amendment stated: "The Congress views with grave concern the deepening involvement of the Soviet Union in the Middle East ... In order to restore and maintain the military balance in the Middle East, by furnishing to Israel the means of providing for its own security, the President is authorized to transfer to Israel, by sale, credit sale or guaranty, such aircraft, and equipment appropriate to use, maintain and protect such aircraft ..."76 Jackson likely included the phrase "grave concern" to reference a February 18 speech by Nixon, when the President noted that the U.S. would view with "grave concern" any Soviet efforts to seek predomination in the Middle East. Representative Gerald Ford (R-MI) similarly referenced "grave concern" when he called on the Administration to sell Phantoms and Skyhawks to Israel while speaking to an American-Israel Public Affairs Committee [AIPAC] luncheon on May $11 .{ }^{77}$ Jackson explained in a statement that the Committee wanted "the Soviet Union to understand that its effort to achieve dominance in the Middle East by tipping the military balance cannot be ignored by the United States." ${ }^{78}$ Although Phantoms were not specifically mentioned by name, the implication was obvious.

The Jackson amendment signaled a dramatic transformation of the U.S.-Israel relationship was in the making. Jackson recognized that the amendment would be "the first time a military assistance commitment to Israel has become the law of the land." ${ }^{\prime 79}$ The amendment indicated that any weaponry to "maintain and protect such aircraft" could be sold to Israel, which

\footnotetext{
76 "Section 501 of the Defense Procurement Act, 1971 (The Jackson Amendment)," Box 6, Folder 6/96, Accession No. 35606, HJP.

${ }^{77} 116 C R, 91^{\text {st }}$ Congress, $2^{\text {nd }}$ Session, $15478-15479$ (May 13, 1970).

78 "Senator Jackson's Mid-East Amendment Adopted by Committee," Box 7, Folder 7/80, Accession No. 35606, HJP.

79 "Panel Oks U.S. Aid: Assist Israel," The Light, San Antonio, TX, June 18, 1970, Box 252, Folder 252/9, Accession No. 35604, HJP.
} 
opened the door to a broad interpretation. And within six months, the United States Congress would authorize the President to sell to Israel, by the most favorable credit terms available, virtually any piece of non-nuclear military hardware. However time would tell that Nixon had reservations about sending more and more sophisticated arms to Israel.

Fulbright opposed the Jackson amendment for two reasons. First, he believed that U.S. foreign policy needed to become more evenhanded in the Middle East and the amendment clearly positioned the United States on the side of Israel. Second, Fulbright argued that Jackson was exceeding his legislative authority. Jackson intentionally circumvented the Foreign Relations Committee, chaired by Fulbright, because he understood that Foreign Relations would never approve such an amendment. The language afforded both Israel and the President too much power in deals concerning military sales to get through Fulbright's committee. So Fulbright tried to persuade Chairman of Armed Services, John C. Stennis (D-MN), to let Foreign Relations take the lead on the issue, arguing that the subject was "within the jurisdiction of the Foreign Relations Committee on the grounds that the amendment relates to 'foreign loans', 'relations ... with foreign nations generally', or 'commercial intercourse with foreign nations'." 80 Fulbright also pointed out that the Senate was already considering an amendment to the Foreign Military Sales Act that addressed the issue of "cash and credit sales of military equipment to foreign nations," including Israel. ${ }^{81}$ The amendment passed the committee level, though Stennis reportedly had "misgivings." 82

Considering the growing unpopularity of the Vietnam War (the invasion of Cambodia and shootings at Kent State had just happened that spring), and with congressional efforts to rein

\footnotetext{
${ }^{80}$ J. W. Fulbright to John Stennis, June 26, 1970, Box 48, Folder 48/9, Accession No. 35606, HJP.

81 Ibid.

${ }^{82}$ Robert S. Allen and John A. Goldsmith, "Plane Sales to Israel," Herald, Everett, Washington, July 6, 1970, Box 252, Folder 252/9, Accession No. 35606, HJP.
} 
in executive power (the Senate repealed the Tonkin Gulf Resolution on June 24), the Jackson amendment went against the grain of recent developments. Rather than limit the President's ability to conduct foreign policy, the amendment instead gave broad powers to the President. In fact, given Nixon's reluctance to sell Phantoms, the legislature was giving the President more power to sell weapons than he wanted!

Another pivotal air battle in the Middle East happened on July 29, which led to acceptance of the ceasefire that eventually ended the War of Attrition. The battle happened over Ain Sunka, along the Gulf of Suez, and involved eight Soviet-piloted Egyptian MiGs, four Israeli Phantoms, and four Israeli Mirages. The Israelis downed four MiGs, and as Craig Daigle points out, "it was only a matter of time before the Soviet Union determined they could not allow a country the size of Israel to dominate its air force and increase its military presence inside Egypt." ${ }^{83}$ The Nixon administration, undoubtedly displeased that U.S.-made Phantoms participated in the conflict, pressed Golda Meir's cabinet to accept the ceasefire proposed by Rogers. Just a week before the air battle, in order to soften the Israeli position, Nixon gave Meir his word that when peace talks began, the U.S. would not pressure Israel to accept the Arab interpretation of UN Resolution 242. While Meir was pleased with the idea, she also reportedly expected "additional compensation" in terms of military and economic aid. ${ }^{84}$ Ultimately, the Meir cabinet voted to approve the ceasefire on July 31, and the War of Attrition ended on August 7.

The Senate continued to push the President to increase military sales to Israel. On July 30, the day after the air battle, Nixon received a letter from 72 senators, echoing the message sent eight weeks earlier to Rogers, to pursue peace in the Middle East based on U.S. military might

83 Daigle, 129.

84 Ibid. 
offered to Israel. ${ }^{85}$ Fulbright was again invited by Ribicoff, and was asked to contact Morris Amitay of Ribicoff's staff. ${ }^{86}$ (Amitay would become executive director of AIPAC in 1974.) Fulbright again declined. He recognized that the Administration had recently deferred new deliveries of the Phantoms and Fulbright "expressed my support of this approach and I will do whatever I can to support a more rational Middle East policy based on our long term interests in the area." ${ }^{\prime 7}$ While George McGovern (D-SD) also urged the Administration to sell the requested aircraft, he cautioned on July 20 that weapons sales alone would not resolve the conflict, and that the U.S. needed to play a more active diplomatic role. ${ }^{88}$

Fulbright tried to gain control of the issue by floating the possibility of a treaty with Israel. He delivered a lengthy speech on the Senate floor on August 24, and urged Israel to agree to a peace settlement that included withdrawal from the occupied territories and a just settlement for the refugee problem. ${ }^{89}$ In return, Fulbright proposed a "treaty of guarantee" with Israel that included an U.S. commitment to protect, militarily if necessary, "the territory and independence of Israel within the borders of 1967." But Israel rejected the proposal immediately, arguing that such assurances were no substitute for bilateral peace agreements with Arab states. The Nixon administration, too, backed away from the proposal. ${ }^{90}$ Unable to find support for his treaty plan, Fulbright formally offered his own amendment on August 30, the day before the Senate vote on the Jackson amendment. The Fulbright proposal sought to "tie the President's authority to extend credits to Israel to enactment of the Foreign Military Sales Act," rather than the Defense Procurement Act. According to the Fulbright amendment, if the military sales act failed to be

\footnotetext{
85 "A Letter to the President Supporting a Firm U.S. Policy in the Middle East ... From 72 Members of the Senate," July 30, 1970, Box 6, Folder 6/96, Accession No. 35606, HJP.

${ }^{86}$ Ribicoff to Fulbright, July 22, 1970, Box 40, Series 48:15, JWFP.

${ }^{87}$ Fulbright to John Olden Williams, July 8, 1971, Box 40, Series 48:15, JWFP.

${ }^{88} 116 C R, 91^{\text {st }}$ Congress, $2^{\text {nd }}$ Session, 25008-25010 (July 20, 1970).

89 “'Old Myths and New Realities - II: The Middle East,” August 24, 1970, Box 36, Series 71:30, JWFP; 116 CR, $91^{\text {st }}$ Congress, $2^{\text {nd }}$ Session, 29796-29813 (August 24, 1970).

${ }^{90}$ Woods, 584-86.
} 
passed, which would have deprived Israel of arms, then the Jackson amendment would automatically be enacted.

The Fulbright measure was crushed while the Jackson amendment passed by a landslide (87-7), and congressional support for Israel reached a new high point. Situated somewhere between Jackson and Fulbright were many of the Senate "doves" who supported Israel but also wanted to curb the White House's ability to sell weapons to foreign nations. Many of these doves supported the measure. Jackson's committee - Armed Services - was generally a hawkish group of senators who, in the summer of 1970, supported the war in Indochina as well as military sales for Israel. ${ }^{11}$ Yet an alliance between hawks and doves in the Senate in support of a dramatic increase of military weapons sales to Israel muted the few calls for a more balanced policy in the region. Later in September the Senate passed the $\$ 19.2$ billion Defense Procurement Act by a vote of $84-3 .{ }^{92}$

Perhaps coincidentally, the Nixon administration finally agreed to sell more Phantoms to Israel on the same day that the Jackson amendment cleared the Senate. The Administration agreed to sell 18 Phantoms, rather than the more ambitious Israeli request for 100 Skyhawks and 25 Phantoms. The decision came in response to the Egyptian/Soviet violations of the August ceasefire that officially ended the War of Attrition. ${ }^{93}$ In particular, Soviet surface-to-air missile sites had been advanced along the Suez Canal, along with the construction of new missile sites, to strengthen Egypt's position; Israel, however, did not violate the ceasefire. ${ }^{94}$ The Administration informed Cairo that the violations of the August ceasefire freed it from a June 19

\footnotetext{
91 "Jackson Criticizes Fulbright," Washington Post, August 30, 1970, Box 252, Folder 252/9, Accession No. 35604, HJP.

92 "Military Bill is OK'd After Senate Beats War Funds Cutoff," The Providence Journal, September 29, 1970, Box 252, Folder 252/10, Accession No. 35604, HJP.

${ }^{93}$ Spiegel, 195.

${ }^{94}$ Daigle, 135-38.
} 
pledge made to Egypt that the U.S. would not sell further Phantoms to Israel. ${ }^{95}$ Thus, Nixon was prepared to arm Israel if he felt Egypt and the Soviet Union, not Israel, threatened to undermine peace efforts.

The reaction to the ceasefire violations revealed the tension between Secretary of State Rogers and National Security Advisor Kissinger. Rogers argued that the violations did not represent a "major change" in the military situation, and he accused Kissinger of trying to "foment a crisis by being so insistent on ceasefire violations." $"$ "It was Kissinger who pushed hardest for more Phantoms for Israel, to the point that Nixon told Chief of Staff H. R. Haldeman to "get K[issinger] off of the Middle East." ${ }^{\text {"97 }}$ For the time being, but not for long, Rogers remained in charge of U.S. foreign policy in the Middle East.

Soon after the Senate passed the Defense Procurement Act, the Jackson amendment was broadened to allow for the sale of nearly any weaponry to Israel. Although the initial proposal was "already one of the most generous arms transfer measures ever written by Congress," according to a report written by Senate and House negotiators, Israel would be able to purchase, on credit, "ground weapons, such as missiles, tanks, howitzers, armored personnel carriers, ordnance, etc. as well as aircraft." ${ }^{\text {"98 }}$ The authors of the report argued that the language "not be narrowly interpreted by the executive branch as imposing a requirement that only those ground weapons which are to be deployed by Israel in the physical proximity to airfields may be acquired by Israel under the authority of this section." "99 The only limit imposed on the bill was an expiration date of September 30, 1972, although the bill could be extended if approved by

\footnotetext{
${ }^{95}$ Hedrick Smith, "U.S. To Give Israel 18 More A-4 Jets," New York Times, 13 November 1970, accessed online with ProQuest, February 5, 2015.

${ }^{96}$ Daigle, 140.

${ }^{97}$ Ibid., 141.

98 "U.S. Plan for Military Aid for Israel Boosted," Scranton Tribune, September 29, 1970, Box 252, Folder 252/10, Accession No. 35604, HJP.

${ }^{99}$ Ibid.
} 
Congress. Thus, Congress encouraged and empowered the President to sell virtually any nonnuclear weapon to Israel on the most favorable credit terms available - a watershed event in the history of U.S.-Israel relations.

After working to secure massive military sales for Israel, Jackson was invited to visit Israel as a guest of the Israeli government in November $1970 .{ }^{100}$ While in Israel he met with Prime Minister Golda Meir and Defense Minister Moshe Dayan, Chief of Staff of the Armed Forces General Haim Bar-Lev, and the Chief of Intelligence General Aharon Yariv; he also visited the Golan Heights and Israeli settlements. ${ }^{101}$ His strong popularity in Israel was confirmed by Hannah Zemer, "the blond beauty" who was editor-in-chief of Davar, a Tel Aviv daily publication. Referring to Jackson's landslide re-election victory in his home state of Washington in 1970 (winning with a whopping 84\%), Zemer commented on an Israeli television program, "You are as popular in Israel as you proved to be in your state of Washington which reelected you. If you moved to Israel and ran for the Knesset I think you would win by as big a margin as you did in Washington." 102

As he neared the end of his trip, Jackson had time to reflect on his amendment. According to Jackson, section 501 "gave the President very, very broad authority to make available military equipment, virtually of all kinds, on long term and favorable credit arrangements." Jackson indicated that the next step was to wait for Nixon to submit a supplemental budget request that utilized the powers given to the President. The Administration was expected to request $\$ 500$ million, although Jackson admitted, "I have no official knowledge

\footnotetext{
100 "Sen. Jackson will Tour Israeli Sites," Washington Post, November 4, 1970, Box 252, Folder 252/11, Accession No. 35604, HJP.

101 "Unofficial Transcript of Senator Henry M. Jackson's News Conference, November 12, 1970, at the American Embassy, Tel Aviv," Box 252, Folder 252/11, Accession No. 35604, HJP.

102 "Jackson Popular in Israel for Strong Pro-Israel Stand," Intermountain Jewish News, Denver, CO, November 27, 1970, Box 252, Folder 252/11, Accession No. 35604, HJP.
} 
as to what the Administration, meaning the President, will request of the Congress."103 However, he urged "the Nixon administration to tell the Soviet Union that unless those surface-to-air missiles are removed from the Suez Canal zone, Israel will get all the American-made weapons she needs to defend herself." 104 When Nixon submitted the supplemental budget request, he asked for the $\$ 500$ million for Israel already authorized by Congress through the Jackson amendment. Among the items promised to Israel were 180 modern tanks (a combination of M-60 main battle tanks and M-48 Patton tanks), ${ }^{105}$ as well as 18 more Skyhawks and the 18 Phantoms agreed to in September. ${ }^{106}$

While the scope and extent of the military hardware far exceeded any previous arrangement, Nixon did not open up the entire U.S. arsenal. Not until the airlift during the 1973 Arab-Israeli war, after significant and surprising Israeli losses, did Nixon agree to provide Israel with more advanced transport planes and helicopters, as well as an assortment of missiles, such as Chaparral surface-to-air missiles, Maverick and Shrike air-to-ground missiles, LAW anti-tank missiles, and TOW missile launchers. ${ }^{107}$

After returning from Israel, Jackson submitted a report to his committee, which argued that the best path to peace lay with arming Israel. He cited Soviet trouble-making as the primary problem in the region. "If there were no Arab-Israeli conflict," wrote Jackson, "the Soviets would invent one." ${ }^{108}$ Indeed, for Jackson "the central problem in the Middle East is the Soviet

\footnotetext{
103 Ibid.

104 "Reassuring but Hardly Surprising," Evening Journal, Wilmington, DE, November 16, 1970, Box 252, Folder 252/11, Accession No. 35604, HJP.

${ }^{105}$ William Beecher, "U.S. Officials Say Israelis Will Get 180 Modern Tanks,” New York Times, October 24, 1970, accessed online with ProQuest, February 5, 2015.

${ }^{106}$ Hedrick Smith, "U.S. To Give Israel 18 More A-4 Jets," New York Times, November 13, 1970, accessed online with ProQuest, February 5, 2015.

${ }^{107}$ Zach Levey, “Anatomy of an Airlift: United States Military Assistance to Israel during the 1973 War," Cold War History, Vol. 8, No. 4 (November 2008), 481-501.

108 "The Middle East and American Security Policy: Report of Senator Henry M. Jackson to the Committee on Armed Forces, United States Senate, December 1970,” p. 8, Box 319, Folder 319/6, Accession No. 35605, HJP.
} 
drive for hegemony ..."109 The solution, according to Jackson, was military support for Israel in order to convince the Soviet Union that diplomacy was the only real option. By arming Israel, the U.S. could further the cause of peace by "discouraging radical Arab hopes for the eventual military defeat of Israel - hopes that lead to a menacing and destabilizing alliance with the Soviet Union and that deepen Soviet influence in the region as a whole." ${ }^{\prime 10}$ Jackson recommended abandoning Rogers's insistence on "insubstantial alterations" to Israeli borders; instead, he called for "defensible borders" and "concrete, physical arrangements to assure Israel's security which, if imperiled, merely invites Soviet exploitation and plants the seed of future war." ${ }^{" 111}$ Until then, Jackson believed it was "unwise to return to the Jarring talks."112

But Nixon continued to fear Israeli intransigence due to military strength. Turning the tables on Jackson (and the Imperial President vs. Congress narrative that views Congress as bent on curbing Presidential power in foreign affairs), Nixon actually declined to use the broad powers authorized to the President via the Jackson Amendment. Instead, when Nixon submitted the new budget in early 1971 he included Israel within the more general request through the Foreign Military Sales Act, rather than the Defense Procurement Act. Instead of authorizing $\$ 500$ million of military sales to Israel through the Jackson amendment, the administration requested $\$ 582$ million for fifteen countries, of which Israel would receive a large share. ${ }^{113}$ The move demonstrated the alliance of Rogers and Fulbright, as Foreign Relations, rather than Armed Services, would handle the request. Jackson was "dismayed by the failure of the Administration's new budget to use the broad authority to extend military credits to Israel that

\footnotetext{
${ }^{109}$ Ibid., 21.

${ }^{110}$ Ibid.

${ }^{111}$ Ibid., 22.

112 "Senator Tells Israel to Seek Roll-Back," The Jewish Chronicle, Kansas City, MO, November 13, 1970, Box 252, Folder 252/11, Accession No. 35604, HJP.

113 “Jackson Holds Israel Credits are Inadequate," Jewish Week and American Examiner, New York, NY, February 4, 1971, Box 252, Folder 252/12, Accession No. 35604, HJP.
} 
was overwhelmingly voted by the last Congress." Calling the Middle East "the cockpit of the cold war," Jackson noted that Moscow might interpret the budget request "as an indication of the indecision and ambivalence at precisely the time when firmness and resolve are needed." 114

Speaking at the B'nai B'rith Inaugural Israel Bond Dinner in Los Angeles on February 7, Jackson made an obvious point. "The truth is that the strongest U.S. policy statement in support of Israel's security has come not from the White House or the State Department," said Jackson, "but from the Congress by adoption of my amendment to the Defense Procurement Act of 1970." $" 115$ Rowland Evans and Robert Novak, writing for the Washington Post, recognized that Jackson was "attracting wide political support from the American Jewish community" as he prepared to run for President in 1972. ${ }^{116}$

Privately, Fulbright expressed his concerns about Senate support for Israel. He wrote to David Nes, a diplomat and old friend, "I am unable to find any substantial support in the Senate for a balanced attitude toward the two contending forces in the Middle East." He blamed, in part, an alliance between Zionists and "our own military establishment." ${ }^{117}$ In a letter to West German ambassador M. Kamel, Fulbright bemoaned the influence of the Senate. "In this instance," wrote Fulbright, "I really believe that the President and the Secretary of State have desired to follow a more even-handed and balanced policy, but that the Congress, especially such members as Senator Jackson, have undermined the Administration's policy." 118

\footnotetext{
114 "Senator Jackson Critical of Middle East Budget Request," January 31, 1971, Box 8, Folder 8/25, Accession No. 35606, HJP.

115 “American Policy and Middle East Security,” by Senator Henry M. Jackson, Address to B'nai B'rith Inaugural Israel Bond Dinner, February 7, 1971, Box 8, Folder 8/26, Accession No. 35606, HJP.

${ }^{116}$ Rowland Evans and Robert Novak, "Nixon's Noose on Israel,” Washington Post, February 19, 1971, Box 252, Folder 252/12, Accession No. 35604, HJP.

${ }^{117}$ Fulbright to David G. Nes, December 1, 1970, Box 40, Series 48:15, JWFP.

${ }^{118}$ Fulbright to The Honorable M. Kamel, December 28, 1970, Box 40, Series 48:15, JWFP.
} 


\section{The Battle of the Branches and Conservative Support for Israel}

The battle between the executive and legislative branches about U.S. foreign policy in the Middle East extended beyond military sales. In early 1971, the Senate took on Secretary Rogers and his newest idea for the Arab-Israeli peace process.

Like the previous spring, Nixon hoped to withhold Phantom sales to better U.S.-Egypt relations and advance peace negotiations through Gunnar Jarring. After Nasser suffered a fatal heart attack during the Black September crisis in Jordan, he was replaced by Vice President Anwar Sadat. Sadat proved more willing than Nasser to warm relations with the U.S. in order to secure a peace arrangement with Israel. In early November he extended the ceasefire by three months, and a November 23 letter from Sadat to Nixon indicated that Egypt was prepared to engage Jarring in further peace discussions. On December 28, Meir announced that Israel would participate in the talks as well. ${ }^{119}$

The peace process seemed to get a boost in early February when Sadat extended the Egyptian-Israeli ceasefire another thirty days and declared that he intended to reopen the Suez Canal to Israeli shipping in return for an Israeli withdrawal from the Canal Zone. Shortly after, Sadat informed Jarring that Egypt was ready to "terminate all states of claims of belligerency with Israel, as well as respect Israel's 'right to live within secure and recognized boundaries'."120 Jarring sent Israel an appealing proposal - Israel was to withdraw to the international boundary in return for Egypt terminating all states of belligerency and opening the Suez Canal and Straits of Tiran to international shipping. ${ }^{121}$ But the Israelis balked at the proposal and chose not to engage Jarring in further discussions.

\footnotetext{
${ }^{119}$ Quandt, 87-92.

${ }^{120}$ Daigle, 163.

${ }^{121}$ Ibid., 166.
} 
Rogers and Nixon were infuriated by the Israelis. Rogers had a heated meeting with Israeli ambassador Yitzhak Rabin on February 24, while Nixon openly questioned sending arms to Israel when they refused to negotiate. During a March 9 meeting, Rogers informed Kissinger, CIA Director Richard Helms, and Defense Secretary Melvin Laird "that he intended to push the Israelis hard over the coming weeks so that they would be more forthcoming in working with Sadat." Rogers intended to offer military sales and financial aid for refugee resettlement and other issues, and in return Israel would withdraw to roughly the 1967 borders. Kissinger warned him that meant a "total confrontation" with Israel, but Rogers was determined. That evening he declared to the Public Broadcasting Service that the U.S. was willing to contribute military forces to an international peacekeeping area in the area, presumably with a Soviet troop commitment, in order to provide heightened security. ${ }^{122}$

The Senate critics sparred with Fulbright over Rogers' new proposal. Jackson called it, "the stupidest thing. It is hard to imagine a more short-sighted and dangerous arrangement for the Middle East than the one that forces Israel back to indefensible borders and then installs Russian troops along those borders." ${ }^{" 23}$ Both Jackson and Jacob Javits (R-NY) delivered speeches on the Senate floor that took aim at Rogers and his proposal, and they were joined in their support by Ribicoff and Humphrey (D-MN). ${ }^{124}$ Many members of Congress feared that the Administration was trying to pressure Israel into a full withdrawal from the territories taken in 1967. Senator Hugh Scott (R-PA) warned against an "imposed" settlement during his acceptance speech for the American Friendship Gold Medal from B'nai Zion on February 21. ${ }^{125}$ Representative Bill

\footnotetext{
${ }^{122}$ Ibid., 166-8.

${ }^{123}$ Philip Warden, “Rogers' Proposal Stupid - Jackson,” Chicago Tribune, March 18, 1971, Box 254, Folder 254/3, Accession No. 35604, HJP.

124 “Javits, Jackson Take Issue with Rogers' Mideast Stand," News Miner, Fairbanks, Alaska, March 23, 1971, Box 254, Folder 254/3, Accession No. 35604, HJP.

$125117 C R, 92^{\text {nd }}$ Congress, $1^{\text {st }}$ Session, 4535-4537 (March 2, 1971).
} 
Frenzel (R-MN) also cautioned against unwarranted pressure on Israel to withdraw to the preJune 1967 lines. ${ }^{126}$ On March 24, Senator Joseph Montoya (D-NM) defended Israel's “commonsense" versus the State Department's "wishful thinking". ${ }^{127}$

Fulbright again came to the defense of the Administration. After explaining how Rogers had briefed the Foreign Relations Committee about his plan for the Middle East, Fulbright said he agreed with Rogers in that a negotiated settlement, rather than "geography and the force of arms," was in the interest of Israel. Furthermore, Fulbright feared that Israel was "giving notice that they do not intend to withdraw from the territories that they took" during the 1967 war. ${ }^{128}$ The Senate uproar convinced Rogers to take an unprecedented step. "For the first time in the nation's history," according to a March 25 article in the Houston Chronicle, "a secretary of state will meet with the entire Senate today for an interchange devoted exclusively to the Middle East. ${ }^{" 129}$ Rogers volunteered to appear in a closed-door session after Senate leadership requested a briefing by "some Middle East policymaker." ${ }^{130}$ But the decision by Rogers to be that policymaker was surprising, and indicated the Administration's hope to rally Senate support for an initiative that could restart the peace process. Rogers was inclined to address the Senate after Israeli Foreign Minister Abba Eban presented the Israeli position at a recent breakfast with 40 senators. ${ }^{131}$ At the same time, the appearance by Rogers would work to offset mounting criticisms that the President did not consult enough with Congress about foreign policy matters.

\footnotetext{
$126117 C R, 92^{\text {nd }}$ Congress, $1^{\text {st }}$ Session, 7081 (March 18, 1971).

${ }^{127} 117 C R, 92^{\text {nd }}$ Congress, $1^{\text {st }}$ Session, 7766 (March 24, 1971).

${ }^{128}$ Philip Warden, "Fulbright Backs Nixon on Mideast," Chicago Tribune, March 24, 1971, Box 254, Folder 254/3, Accession No. 35604, HJP.

129 Thomas B. Ross, "Rogers Will Brief Entire Senate on Middle East," Houston Chronicle, March 25, 1971, Box 252, Folder 252/12, Accession No. 35604, HJP.

${ }^{130}$ Ibid.

131 Tad Szulc, “U.S. Aides Clarify Views on Mideast,” New York Times, March 25, 1971, Box 254, Folder 254/3, Accession No. 35604, HJP.
} 
The meeting revealed the strength of Senate opposition. Rogers had been pushing for Israel to agree in principle to withdrawal as a precondition for peace agreements, but when meeting with the senators he backed off that idea. Instead, he shifted the emphasis to “demilitarization of the Sinai Peninsula and an as yet undefined security arrangement for Sharm El-Sheikh that is satisfactory to Israel.” Rogers had proposed a peacekeeping force to be used along the Israel-Egypt border and specifically at Sharm El-Sheikh in order to keep open the Straits of Tiran. But after the meeting, Jackson claimed that "Rogers promised that if an American military role in the Middle East with the Russians ever was contemplated again, the administration would seek Senate approval."132 Perhaps most importantly, Javits reported after the meeting that the Rogers proposal meant "no settlement would be imposed" on Israel. ${ }^{133}$ Even after Rogers met with Nasser in Cairo that May, Senator Birch Bayh (D-IN) expressed his concern over reports that Rogers had promised Nasser that the U.S. would demand "no further compromises" from Egypt. Bayh hoped that such reports were false, and Ribicoff reminded his colleagues that Rogers had assured the Senate in March that Israel would not be pressured at all to remove from the occupied territories. ${ }^{134}$ Beyond budgetary matters, the Senate was fundamentally affecting U.S. foreign policy in the Middle East, and in combination with support for military sales to Israel, the Senate emerged as a formidable challenge to the Nixon administration's handling of the peace process.

A major shift was happening as liberal support for Israel was ebbing and conservative support was rapidly increasing. Jackson and James L. Buckley (R-NY) each spoke at the American Zionist Federation's celebration of Israel's independence on April 28. Rather than

\footnotetext{
132 R. H. Shackford, "Rogers Retreats on Mideast Plan," The Pittsburg Press, March 26, 1971, Box 254, Folder 254/3, Accession No. 35604, HJP.

${ }^{133}$ Lewis Gulic, "Rogers Details U.S. Aim in Mideast Peace," The Salt Lake City Tribune," March 26, 1971, Box 254, Folder 254/2, Accession No. 35604, HJP.

${ }^{134} 117 C R, 92^{\text {nd }}$ Congress, $1^{\text {st }}$ Session, $17355-17356$ (June 1, 1971).
} 
impose a settlement on Israel, Jackson suggested that an Israeli withdrawal to defensible borders should be matched by a Soviet withdrawal from Egypt. ${ }^{135}$ He urged the U.S. government to drop the Rogers formula, which Jackson called "the greatest obstacle" to achieving a peace in the region. ${ }^{136}$ Buckley argued that it was unreasonable to expect Israel to return to the 1967 borders with paper guarantees from Arab states and the promise of an international peacekeeping force precisely the situation that actually led to the 1967 war. ${ }^{137}$ Over the next two days AIPAC hosted a two-day luncheon for the Senate and House that was attended by 350 Jewish leaders from 30 states. Senate Minority Leader Hugh Scott (R-PA) told the Senate luncheon that during 1970 the U.S. government recognized a "genuine convergence of interest" between Israel and the United States. He added that providing arms to Israel "must and will continue ... and frankly, it will continue under any administration in this country." During the House luncheon, Republican Gerald Ford accused two Senate Democrats - Fulbright and Edmund Muskie of Maine - "of undermining American support for Israel." The accusations were enough for Muskie to issue a statement denying Ford's charges; in particular, Muskie denied telling Soviet Premier Alexei Kosygin "that the American people were divided about arms aid to Israel." 138 In a reversal of conventional wisdom at the time, conservatives were putting liberals on the defensive about U.S. support for Israel.

Nixon recognized that conservatives, not liberals, had emerged as Israel's more reliable friend. In a memorandum dictated to Kissinger during March 1970, Nixon described "the danger for Israel of relying on the prominent liberal and dove senators of both parties to come through in

\footnotetext{
135 "Remarks of Senator Henry M. Jackson (D., WASH.) before the American Zionist Federation Israeli Anniversary Committee, April 28, 1971, Box 8, Folder 8/54, Accession No. 35606, HJP.

136 “Senator Urges U.S. Scrap Rogers Formula for Middle East Peace," Hebrew Watchman, Memphis, TN, April 29, 1971, Box 254, Folder 254/3, Accession No. 35604, HJP.

137 “U.S. Senators Agree Israel to Stand Pat," Jewish Chronicle, Dayton, OH, May 6, 1971, Box 254, Folder 254/3, Accession No. 35604, HJP.

${ }^{138}$ George Sherman, "Israel Gets Bipartisan Boost," The Evening Star, Washington D.C., May 1, 1971, Box 254, Folder 254/3, Accession No. 35604, HJP.
} 
the event a crisis arose ..." The liberal response to the Vietnam War weighed heavily on Nixon's mind. "When the chips are down they [liberal and dove senators] will cut and run," said Nixon, "not only as they are presently cutting and running in Vietnam, but also when any conflict in the Mideast stares them straight in the face." According to Nixon, Israel's "real friends (to their great surprise) are people like Goldwater, Buckley, RN et al., who are considered to be hawks on Vietnam but who, in the broader aspects, are basically not cut-and-run people whether it is in Vietnam, the Mideast, Korea, or any place else in the world ..."139

But during the summer of 1971, despite his support for Israel, Nixon continued to fear that weapons sales would undermine peace negotiations, and he sought to reduce congressional influence on U.S.-Israel relations. During an NSC meeting on July 16, Nixon recommended that Joe Sisco fly to Israel to have discussions about peace negotiations as well as Israel's need for additional aircraft. But the timing was important because Congress would be out of session "for the best part of August." Nixon said that "we are not going to have a policy governed by domestic political opinion, but we do have 'more running room' when Congress is out of session, particularly on the aircraft question." Nixon asked that Sisco keep "a very low-profile" and "suggested that Mr. Sisco go out the following week and then stay there until Congress gets out of town." Nixon added, "Don't promise them a damn thing. This is not going to be a free ride this time. From now on it is quid pro quo."140

For her part, Israeli Prime Minister Golda Meir also recognized that U.S. conservatives had become the better friend of Israel. The New Left was increasingly hostile towards "imperialistic" Israel, and anti-Semitism was rising in the U.S. following the 1967 Arab-Israeli

\footnotetext{
${ }^{139}$ Richard Nixon, The Memoirs of Richard Nixon (New York: Simon \& Schuster, 1978), 481. See also, Memorandum From President Nixon to the President's Assistant for National Security Affairs (Kissinger), Washington, March 17, 1970, FRUS, 1969-1976, Vol.XXIII, Arab-Israeli Dispute, 1969-1972, Document 102.

${ }_{140}$ Memorandum for the Record, San Clemente, July 16, 1971, FRUS, 1969-1976, Vol. XXIII, Arab-Israeli Dispute, 1969-1972, Document 243.
} 
war. ${ }^{141}$ Some U.S. Jews took issue with Meir for her praise of Nixon, but she responded, "Have you any liberals who can supply us with Phantoms? My business as Prime Minister is to ensure that we have Phantoms and that we have the answers to missiles and that if we are going to lose lives in the next war we have a chance to win." 142

Conservative congressional support for military sales to Israel continued to grow. Robert S. Allen, correspondent for The Christian Science Monitor, wrote that a "Republican Revolt" had started over the Administration's unwillingness to sell more Phantoms to Israel. Allen noted that Senator Scott and Representative Ford had both publicly urged the Administration to sell 60 Phantoms to Israel. "Particularly incomprehensible and infuriating to Republican Congressional leaders," wrote Allen, was Nixon's support for Rogers. Republicans hoped that Nixon would be responsive to Senate advice and overrule Rogers like he had "done on virtually all other major policies." ${ }^{143}$ During a speech to the Senate floor on September 23, 1971, Jackson reminded the Administration of the strong Senate support for his amendment the previous year, and claimed that no one "could remain uncertain as to the policy of the United States in the Middle East. Today the best hope for peace in that troubled region lies with an Israel strong enough to defend itself and thereby deter aggression." ${ }^{144}$ In order to spur the Administration into action, Jackson felt it was necessary to offer another amendment that specifically earmarked $\$ 250$ million, taken from the $\$ 500$ authorized by the Jackson amendment, for the sale of Phantom fighters to Israel. But he add that if "funds are authorized and appropriated in a timely fashion, and if they are

\footnotetext{
${ }^{141}$ Melvin I. Urofsky, We Are One! American Jewry and Israel (Garden City, NY: Anchor Press, 1978$), 370$.

142 Ibid., 388.

${ }^{143}$ Robert S. Allen, "Republican Revolt Brewing Over Failure to Sell F-4s to Israel," Appeal-Democrat, Marysville, CA, September 13, 1971, Box 254, Folder 254/4, Accession No. 35604, HJP.

144 "To Maintain a Balance in the Middle East," p. 5, Remarks by Senator Henry M. Jackson, Senate Floor, September 23, 1971, Box 8, Folder 8/94, Accession No. 35606, HJP.
} 
expanded for the purpose of providing these vital planes, I would adjust my amendment accordingly and as the situation dictates."145

Rogers continued to resist the call for more Phantom sales because the Administration believed that the military balance of power was still in Israel's favor. ${ }^{146}$ However behind the scenes, rumors circulated that Nixon was considering taking Rogers off the Middle East, replacing him with Kissinger, which meant a stronger pro-Israel tilt from the State Department. $^{147}$

The Senate responded in October by passing a bipartisan resolution, supported by 78 senators, that urged the Administration to provide Israel with more Phantoms, "without further delay."148 The resolution was opposed Senate Majority Leader Mike Mansfield (D-MT) and Fulbright, as well as liberal Republicans Aiken and John Sherman Cooper of Kentucky. ${ }^{149}$ Although the resolution simply expressed the sense of the Congress (like in 1968), it publicly affirmed broad, bipartisan Senate support for Phantom sales to Israel.

Jackson followed up the resolution by making good on his earlier threat. On November 23 , the Senate voted $82-14$ in favor of a Jackson amendment to a $\$ 70.2$ billion defense appropriations bill, which again set aside $\$ 500$ million in military credit sales to Israel, but earmarked half to be used for Phantom sales. The favorable Senate vote came after Rogers met with eight senators and again refused to sell any more Phantoms to Israel. ${ }^{150}$ The State

\footnotetext{
145 Ibid.

${ }^{146}$ Marquis Childs, "Rogers to Israelis: No More Planes," The Detroit News, September 30, 1971, Box 254, Folder 254/4, Accession No. 35604, HJP.

147 “Robert S. Allen, "Pressure on Rogers," Tulsa World, October 15, 1971, Box 254, Folder 254/4, Accession No. 35604, HJP.

148 “78 Senators Urge Jets for Israel,” Washington Post, October 16, 1971, Box 254, Folder 254/4, Accession No. 35604, HJP.

149 John W. Finney, “78 Senators Ask Phantom Jets for Israel,” New York Times, October 16, 1971, Box 254, Folder 254/4, Accession No. 35604, HJP.

150 “Senate Votes \$500m Credit for Israel Jets, Arms,” Boston Globe, November 24, 1971, Box 254, Folder 254/4, Accession No. 35604, HJP.
} 
Department predictably expressed a negative view of the Jackson amendment, arguing the Administration had already requested $\$ 300$ million in military credit sales through pending legislation. Ultimately, the Jackson amendment was removed from the Defense Appropriations Act (the House had never voted on the amendment) after a Senate-House conference committee report determined that "the same sum was available to Israel in the continuing resolution for foreign aid pending before both Houses.” Basically, since the Jackson amendment from the previous year had already been approved by Congress with $\$ 500$ for military credit sales set aside, the second Jackson amendment was deemed unnecessary. ${ }^{151}$

In December 1971, Nixon agreed to sell more Phantoms to Israel. Historian Noam Kochavi makes a valuable point in arguing that Nixon's shift had much to do with Israeli loyalty to the President amidst the growing opposition to the Vietnam War, along with visible support from Meir and Rabin in American Jewish circles leading up to the 1972 election. ${ }^{152}$

But Kochavi, like other scholars, understates the importance of congressional insistence on Phantom sales and larger military sales packages. Jackson spearheaded an effort to use legislation to push more weapons sales to Israel, which collected overwhelming congressional support. Importantly, Nixon's decision to sell Phantoms in September 1970 came on the day that the Jackson amendment was passed; the decision in December 1971 came on the heels of a nonbinding resolution passed in October 1971 and the revised Jackson amendment passed in November 1971. While congressional opposition to the Administration was not the only factor that influenced Nixon to finally agree to more Phantom sales in December 1971, it was almost certainly an important one.

\footnotetext{
151 “\$500 Million Still Available,” Jewish World, Albany, NY, December 23, 1971, Box 254, Folder 254/4, Accession No. 35604, HJP.

152 Kochavi, 4-5, 21-24.
} 
Along with rewarding Israeli loyalty and congressional insistence on increased military sales, Nixon's shift was influenced by two other factors as well. First, military sales and the peace process were inextricably linked, and the Phantoms had always been a bargaining tool for the Nixon administration - to maintain leverage with the Jewish state while also appeasing Arab states and the Soviet Union by not ramping up the arms race in the Middle East. In November 1971, Israel informed the US government that it could not engage Egypt in peace discussions regarding the Suez Canal without a deal on the Phantoms. Additionally, Israel "sought assurances that the United States would restrict itself to a passive role in the negotiations and specifically would not put forward any compromise proposals." ${ }^{153}$ Thus, the decision by Nixon removed an obstacle to peace negotiations. By January 21, after securing new shipments of Phantoms and US neutrality in negotiations, the Meir government agreed to participate in talks with Egypt through Jarring. ${ }^{154}$ The Israeli flexibility was rewarded with an agreement that more than doubled the expected jet sales. Rather than offer 18 Phantoms and 36 Skyhawks, which was expected, the Administration agreed to sell 42 Phantoms and 90 Skyhawks over the following two-to-three years. ${ }^{155}$ The United States had truly replaced France as Israel's main weapons supplier.

Second, Nixon's shift demonstrated how domestic politics can influence foreign policy decisions. Since 1972 was an election year, Nixon believed that a Middle East peace plan had to wait until after the election. During the Moscow summit in May 1972, when the US and USSR signed the Strategic Arms Limitation Treaty (SALT) agreement, Nixon told Soviet leadership

\footnotetext{
153 Terrence Smith, “Decision to Resume Sales of F-4's to Israel Reported,” New York Times, 31 December 1971, accessed online with ProQuest, 30 January 2015.

${ }^{154}$ Bernard Gwertzman, "Israel is Termed Ready for Talks," New York Times, 22 January 1972, accessed online with ProQuest, 30 January 2015.

${ }^{155}$ William Beecher, "U.S. to Supply Israel 42 Phantom Jets," New York Times, 6 February 1972, accessed online with ProQuest, 31 January 2015.
} 
that it was to put the Middle East on ice because "we can't settle before the [presidential] election, but after that we can make progress in a fair way." ${ }^{156}$ Therefore releasing the jets to Israel in the first part of 1972 did not compromise peace prospects, in Nixon's mind anyway, because the issue could not be resolved for the next year. Moreover, such a move by Nixon would generate a certain amount of goodwill within the American Jewish community that could translate into more votes for Nixon and the Republican Party come November 1972. Steven Spiegel points out that in addition to increased aid to Israel, George McGovern's views on defense spending and criticisms of Israel, combined with Ambassador Rabin's vocal support of Nixon, contributed to Nixon securing 39 percent of the Jewish vote in 1972, as opposed to 17 percent in $1968 .{ }^{157}$

However on October 2, a month before the election, Senator Alan Cranston (D-CA) took Nixon to task while speaking on the Senate floor. Cranston reminded his colleagues that while Nixon stressed his pro-Israel position for the upcoming election, his first three years in office were marked by "the infamous Rogers plan," "incessant State Department pressure on Israel," and "dribbles of vital military aid which the administration begrudgingly granted only under the steady hammering of the Congress.” Republican Senator Scott followed Cranston by defending Nixon and questioning McGovern's support for Israel. The debate continued to follow party lines as Senators John Tunney (D-CA) and Birch Bayh (D-IN) joined with Cranston in criticism of Nixon's Middle East record and support for McGovern. Cranston concluded the discussion by pointing to an increasingly important concern of the Congress - the emigration tax on Soviet Jews. ${ }^{158}$ While U.S. domestic politics certainly influenced the U.S.-Israel relationship, the

\footnotetext{
156 Daigle, 224.

157 Ibid.

${ }^{158} 118 C R, 92^{\text {st }}$ Congress, $2^{\text {nd }}$ Session, $33037-33045$ (October 2, 1972).
} 
reverse was true as well - support for Israel was obviously an important issue for the 1972 presidential election.

By selling more Phantoms to Israel, Nixon managed to simultaneously start and stop the peace process. Israel agreed to participate in negotiations with Egypt through Jarring, and Sadat, despite his public denunciations of U.S. support for Israel, was eager to restart negotiations.

Kissinger received Egyptian National Security Adviser Hafix Ismail for a private meeting in late February 1973, part of a "backchannel" effort to establish closer U.S.-Egypt relations and make progress towards peace. Yet Kissinger made a point of telling Israeli Ambassador Rabin that he would "make no proposals to them, no promises."159 Ismail conveyed Sadat's urgent desire to end the conflict, and that the Egyptian President expected a state of peace by the end of September. Ismail went so far as to indicate that Egypt would sign a separate peace agreement with Israel, including free passage through the Suez Canal and acceptance of "legitimate concerns" of Israel's security. But Kissinger doubted the sincerity of the Egyptian proposal, particularly its plan of "normalization" of relations with Israel, which fell short of recognizing the State of Israel. Kissinger, who never seriously considered the Egyptian proposals, balked at the opportunity to oversee far-reaching peace agreements between Israel and Egypt. ${ }^{160}$ With more Phantoms on the way, Israel did not feel the need to negotiate. When Nixon pushed Meir to “get off dead center" in negotiations on March 1, 1973, Meir declined and referred to Israel's military superiority, thanks to the Phantoms. "We never had it so good," she said. "The planes are coming in and we are okay through '73."161 Time would tell, however, that Israel was not okay through ' 73 .

\footnotetext{
${ }^{159}$ Ibid., 250.

${ }^{160}$ Ibid., 250-258.

161 Ibid., 258.
} 
At times Congress plays an enlarged role in shaping U.S. foreign policy in the Middle East, especially when foreign policy issues affect Israeli security. During Nixon's first term, Congress used the issue of Phantom sales as a means for challenging the Administration's position on the U.S.-Israel relationship and the peace process. Nixon recognized that selling Phantoms to Israel could badly undermine peace negotiations - Arab states would protest U.S.Israeli collusion, the Soviet Union would likely send more weapons to Egypt, and Israel would hunker down. But Senate forces, led by Jackson, pushed the Administration hard to sell more weapons to Israel, especially Phantoms. Pressure on Rogers was so intense that he felt the need to take an unprecedented step and address the entire Senate about his peace plan, during which he retreated from previous positions. Strong congressional insistence on substantial military sales to Israel, coincidentally during a time of congressional efforts to limit presidential military sales abroad, weakened the Nixon administration's ability to facilitate a peace agreement. The shift in Nixon's policy bedeviled Rogers's successor - Henry Kissinger - who also found it difficult to get the Israelis to go along with the U.S. peace process without having leverage over Israel with military sales. Once Israel had a generous package deal involving Phantoms and Skyhawks, the slow-moving peace process stalled and war resumed in October 1973.

The story of the Jackson amendment, with its widespread Senate support, helps to explain why military aid to Israel started to climb during Nixon's presidency. Jackson's amendment was a turning point with regard to increased congressional assertiveness in the making of U.S.Middle East policy, and U.S. foreign policy more generally. Congress flexed its muscles over U.S. policy towards Israel at particularly important times in the peace process, such as May 1975 when 76 senators signed a letter for President Gerald Ford that similarly demanded military 
supplies for Israel without pressure to move a certain direction with peace negotiations. Nixon had already requested aid for Israel through the Foreign Military Sales Act, which was being considered by the Foreign Relations Committee, so he clearly meant to authorize military sales to Israel. Moreover, the Nixon Doctrine was based on supplying arms to a regional ally in order to avoid deploying U.S. military personnel abroad. But the extent and scope of such sales were substantially broadened by the Jackson amendment, and justified by the increased Soviet military presence in the region and violations of the ceasefire agreement. Nixon's willingness to ask Congress for larger military packages for Israel in the following years was certainly influenced by Jackson's insistence on the full $\$ 500$ million being authorized annually. Nixon was leery about agreeing to large arms deals with Israel, so much so that he intentionally avoided using the broad powers bestowed to him by Congress when he submitted the budget in early 1971, a reversal of the narrative of the Imperial Presidency. But Jackson continued to insist on larger aid packages for Israel. His original amendment was extended for an additional year in 1972, and then again in 1973 for an additional two years. ${ }^{162}$ In order to fully understand why U.S. military aid to Israel took off during Nixon's first term and remained high for the foreseeable future afterwards, the influence of the legislative branch demands consideration.

The debates about military sales to Israel, especially Phantoms, signaled an important shift was underway in U.S. politics. Conservative forces in the United States were finding common cause with Israel, pointing to the evil machinations of the Soviet Union as justifying a stronger Israel unfettered by calls for a comprehensive peace settlement. Additionally, Israel's military strength and ability to defend itself stood in stark contrast to the deteriorating situation in South Vietnam. Israel had always drawn strong support from the United States Congress, but support for Israel had traditionally been a liberal cause. That started to change with the

162 “Selected Senate Actions Concerning Israel," Box 41, Series 48:15, JWFP. 
congressional challenge to the Nixon Administration over Phantom sales to Israel. The conservative critique of the Administration, and specifically Rogers, was to not impose a peace settlement and generously provide for Israeli security in order to meet the growing Soviet threat in the region - two reasonable arguments during the Cold War. But by doing so, the Senate helped to ensure that Israel would be guaranteed only a Phantom peace.

War erupted again in October 1973, almost six years after the passage of U.N. Resolution 242. Frustrated by the diplomatic stalemate, Egyptian President Anwar Sadat secretly coordinated with Syrian President Hafez al-Asad to attack Israel on Yom Kippur, October 6, 1973. The war, along with the diplomatic aftermath, witnessed the most active period of U.S. diplomacy involvement in the Arab-Israeli peace process as successive administrations aimed to prevent a third war in the region. 


\section{Chapter 4: \\ Stepping Forward: Nixon, Kissinger, and Step-by-Step Diplomacy}

The 1973 Arab-Israeli war forced the Nixon Administration to become more actively involved in the peace process. After suffering initial losses, Israel managed to reverse the tide and win the war, thanks in large part to a massive resupply effort from the United States. The U.S. resupply also resulted in an oil embargo imposed on the U.S. by OPEC (Organization of Petroleum Exporting Countries), which shocked the international economy and exacerbated an existing energy crisis in the United State. Overwhelmed by the Vietnam War and domestic upheaval, American officials had preferred to remain aloof from the peace process. But the oil embargo and dangerous instability in the region forced the Administration to become much more actively involved.

The postwar American diplomatic effort, led by Secretary of State and National Security Adviser Henry Kissinger, aimed to accomplish three primary goals - strengthen the existing ceasefire, improve U.S.-Arab relations, and provide Israel an opportunity to withdraw from the occupied territories. American relations with Arab states had been severely strained by the 1967 war, and in fact several Arab countries, including Egypt and Syria, had severed diplomatic relations with the United States. The postwar environment in 1973 offered both sides an opportunity to mend relations, and Kissinger planned to use improved U.S.-Arab relations as a way to further remove Soviet influence from the region and end the oil embargo. Moreover, the process itself would provide Israel enough time and protection to negotiate a way out of the occupied territories.

Henry Kissinger employed step-by-step diplomacy to advance the American position. He hoped to use a series of disengagement agreements connected to the October hostilities as a means for restarting the stalled peace process. Each modest agreement would create greater 
momentum towards lasting bilateral peace treaties, while at the same time the psychological atmosphere in the Middle East would become more conducive to peace efforts. Step-by-step diplomacy aimed for the implementation of Resolution 242 at some point in the future, and a conference in Geneva would have likely been the setting for the signing of the peace agreements.

But powerful domestic forces undercut the American efforts, and along with seemingly intractable problems between Arabs and Israelis, the Administration's plan fell apart. The power and the prestige of the executive branch had been ruined by Watergate, the "Plumbers," and the Vietnam War. ${ }^{1}$ President Nixon was forced to resign in August 1974 - during the middle of stepby-step diplomacy - replaced by the unelected Gerald Ford. Although Kissinger remained in office, accusations of his alleged role in wiretapping eroded his credibility and complicated his ability to advance the peace process. The U.S. economy, already struggling due to inflation, unemployment, and international competition, was made worse by an oil embargo that made an existing energy crisis even worse. Congressional involvement in foreign affairs continued to accelerate, marked especially by passage of the War Powers Act in late 1973, which forced the President to get Congress's approval to deploy U.S. forces abroad for more than 60 days. While geopolitical problems plagued the peace process, American domestic political factors played a critical role in determining the nature and extent of American involvement, and scholars have underestimated and understated such factors during this time period. ${ }^{2}$

One significant factor was the role of pro-Israel lobbying forces that sought to influence American decision-making in order to relieve pressure on Israel. In their controversial book, The

\footnotetext{
${ }^{1}$ The Plumbers were a group of White House officials who organized and executed illegal activities, like the breakin at Watergate, that aimed to strengthen the President's position and discredit Nixon's opponents.

${ }^{2}$ The most thorough account of domestic influences on US foreign policy in the Middle East is Steven Spiegel's The Other Arab-Israeli Conflict: Making America's Middle East Policy, from Truman to Reagan (Chicago: The University of Chicago Press, 1985). See also, William B. Quandt, Peace Process: American Diplomacy and the Arab-Israeli Conflict since 1967, Third Edition (Washington D.C.: Brookings Institution Press, 2005), and Richard C. Thornton, The Nixon-Kissinger Years: Reshaping America's Foreign Policy, Second Edition (St. Paul: Paragon House, 2001).
} 
Israel Lobby and U.S. Foreign Policy, John Mearsheimer and Stephen Walt argue that the Israel lobby has had a profound influence on U.S. foreign policy in the Middle East, oftentimes to the detriment of American interests. ${ }^{3}$ Mearsheimer and Walt were concerned with more recent events - especially the US war with Iraq in 2003 - which explains why the authors devoted little attention to step-by-step diplomacy. ${ }^{4}$ But even when discussing the Nixon administration, the authors dismiss the importance of Congress at this time and instead imply that the Administration willingly advanced an Israeli position. The authors continually point out that large aid packages for Israel have undermined U.S. interests, but fail to discuss the role of Congress during the final years of the Vietnam War, one of the most active periods of congressional involvement in U.S. foreign policy, which coincided with step-by-step diplomacy. ${ }^{5}$

Kissinger himself recognized that domestic forces significantly impacted American foreign policy at the time. ${ }^{6}$ However, according to Kissinger, of all the foreign policy concerns, "the domestic weakness produced by the traumas of Vietnam and Watergate had the least impact on our Middle East policy."7 But notice that he chose not to say "domestic factors" or "domestic

\footnotetext{
${ }^{3}$ Mearshimer and Walt offer a very helpful explanation of the Israel lobby - "The real reason why American politicians are so deferential is the political power of the Israel lobby. The lobby is a loose coalition of individuals and organizations that actively works to move U.S. foreign policy in a pro-Israel direction ... it is not a single, unified movement with a central leadership, and it is certainly not a cabal or conspiracy that 'controls' U.S. foreign policy. It is simply a powerful interest group, made up of both Jews and gentiles, whose acknowledged purpose is to press Israel's case within the United States and influence American foreign policy in ways that its members believe will benefit the Jewish state.” John J. Mearshimer and Stephen M. Walt, The Israel Lobby and U.S. Foreign Policy (New York: Farrar, Straus and Giroux, 2007), p. 5.

${ }^{4}$ The authors move from late October 1973 to September 1975, overlooking the course of step-by-step diplomacy during the Nixon Administration. Mearshimer and Walt, p. 44.

${ }^{5}$ Scholarship has understated the importance of the Israel lobby on step-by-step diplomacy. Mearshimer and Walt note that Steven Spiegel's work tends to "downplay the lobby's influence" (19). Mitchell Bard has written a valuable book that looks specifically on the influence of the Israel lobby on the executive and legislative branches of the US government. He includes chapters that explore specific examples, such as LBJ's decision to sell Phantom jets to Israel, the Jackson-Vanik Amendment, and the Camp David Peace Accords; unfortunately, Bard does not address the influence of the lobby on step-by-step diplomacy. Mitchell Geoffrey Bard, The Water's Edge and Beyond: Defining the Limits to Domestic Influence on United States Middle East Policy (New Brunswick: Transaction Publishers, 1991). See also, Edward Tivnan, The Lobby: Jewish Political Power and American Foreign Policy (New York: Simon \& Schuster, 1987).

${ }^{6}$ Henry Kissinger, Years of Upheaval (New York: Simon \& Schuster, 1982), pp. 122-127.

${ }^{7}$ Ibid., p. 195.
} 
politics." Kissinger's guarded position is hard to reconcile with documentation, which clearly reveals that certain pro-Israel organizations often tried to work against the White House. While Nixon and Kissinger had their hands full in 1973-74, the weakened White House invited even more opposition during Gerald Ford's tenure. The historical record indicates that domestic politics, and especially pro-Israel lobbying forces, mattered a great deal for U.S. foreign policy in the Middle East, even if Kissinger preferred to not discuss them in his memoirs for wider readership. The ability of historians to chart domestic influences like the Israel lobby requires a willingness on the part of American political officials to detail and discuss such forces, which Kissinger and others undoubtedly realize.

Domestic factors were enormously impactful on U.S.-Middle East policy, and significantly contributed to the downfall of the step-by-step approach. While geopolitical realities determined the broad parameters of Kissinger's diplomacy and peace program, the implementation and maneuvering by Kissinger to try to reach his goals revealed the power of domestic forces lined up against the executive branch. Step-by-step diplomacy produced two disengagement agreements in 1974 - between Egypt and Israel in January (Sinai I) and Syria and Israel in May - and led to the reestablishment of diplomatic relations between the U.S. and several Arab countries. But after the Syrian agreement, step-by-step diplomacy gradually lost momentum. Nixon's increasingly untenable position, which culminated in his resignation in August 1974, undermined the power of the executive branch to conduct such important and complicated diplomacy. It would be left to Gerald Ford's administration, a caretaker presidency, to see through the most intricate and sincere U.S. diplomatic effort to resolve the Arab-Israeli conflict, a process that began in October 1973. 


\section{Defining a Position amidst Domestic Troubles}

On 6 October 1973, Egypt and Syria attacked Israel on Yom Kippur, which started the 1973 Arab-Israeli war. During the first few days of the war, Egyptian forces successfully crossed the Suez Canal and advanced into the Sinai Peninsula, while Syrian forces recaptured territory in the Golan Heights. The Arab armies received substantial support from the Soviet Union, which airlifted military aid to both Syria and Egypt. In response to the Soviet airlift, and to reverse the tide of the war, the United States enacted its own airlift to Israel. In response to the airlift, as well as a multi-billion dollar American aid package for Israel, OPEC placed an embargo on oil to the United States and drastically reduced the oil flowing to Western Europe and Japan. The American airlift changed the course of the war as Israeli forces, initially driven back, were able to regroup and push the Egyptian and Syrian armies back to the pre-war lines. The combatants agreed to a ceasefire on 22 October, in line with UN Resolution 338 that called for the immediate implementation of UN Resolution 242. But the integrity of the ceasefire quickly deteriorated as the Egyptian Third Army was encircled by Israeli forces, cut off from escape and resupply. After a Soviet message to Nixon suggested the possibility of unilateral Soviet military intervention to relieve the besieged Egyptian army, followed by Kissinger elevating the DEFCON level from 4 to 3 , a second ceasefire took hold on 25 October. $^{8}$ The postwar American effort to resolve the Arab-Israeli conflict, which was the most intensive and productive period of U.S. diplomacy in the region, would begin at Kilometer 101, on the road between Cairo and Suez, where Israel agreed to the peaceful release of the Egyptian Third Army.

The Nixon Administration was in an awkward position following the war. On the one hand, the oil embargo and violent instability in the Middle East demanded greater American

\footnotetext{
${ }^{8}$ DEFCON, which stands for "defense readiness condition", has five levels of readiness for U.S. armed forces based on perceived threats.
} 
involvement in the peace process. But on the other hand, American officials could not impose a settlement on the belligerents and instead could only try to help the sides come together in the hopes of fully implementing UN Resolution 242; the meaning of that implementation was to be left to negotiations. Ultimately, the Administration tried to balance a U.S.-Israel special relationship with an effort to establish stronger U.S.-Arab relations, which proved to be a difficult task.

Henry Kissinger employed a step-by-step diplomatic process to detangle the complex issues connected to the Arab-Israeli conflict, and aimed to gradually lead the combatants to bilateral peace agreements in line with implementation of UN Resolution 242. In his memoirs, Kissinger points out that he has been criticized for not pursuing an immediate comprehensive settlement in the aftermath of the 1973 war. ${ }^{9}$ But Kissinger explains his reasons for not choosing that path. Israel rejected a return to the 1967 borders, and "adamantly" refused to give back the Old City of Jerusalem, which Arab states would not accept. Israel was preparing for elections in December 1973, which meant no cabinet would have the authority to negotiate a comprehensive settlement, especially in the aftermath of a shocking attack on Yom Kippur. On the Arab side, a comprehensive agreement required consensus by all parties involved, which meant radical forces could veto any such agreement. The Soviet Union would support the Arab position and seek maximum gains, thereby further extending its influence. In such a situation, Europe and Japan would support the Arab position for fear of a crippling oil embargo, which would leave the U.S. isolated..$^{10}$ Almost certainly, any attempt for a comprehensive settlement would have quickly fallen apart and furthered the risk of war.

\footnotetext{
${ }^{9}$ Ibid., p. 615.

${ }^{10}$ Ibid.
} 
Instead, Kissinger sought to use step-by-step diplomacy to restart the peace process. The idea was to change the psychological atmosphere of the region before aiming for a broader peace program. Kissinger hoped to use disengagement agreements connected to the 1973 war as a way to both further defuse tensions and engage the combatants politically. The approach would create momentum to a larger peace, and simply by agreeing to disengage with Israeli forces, Arab states would implicitly recognize the state of Israel. With a changed psychological atmosphere and a recent history of political agreements, then the combatants could hopefully, at some point, come to an agreement about implementing UN Resolution 242. In reality, even if Kissinger had wanted to try for a comprehensive settlement, in the end it would have meant implementation of 242 . In other words, step-by-step diplomacy had no reason to aim for a specific final arrangement; the aim of the gradual approach was to help the combatants get to a point that they could negotiate bilateral peace agreements in line with mutually-agreed upon interpretations of UN Resolution 242.

But the ambiguity of UN Resolution 242 - intentionally crafted with vague language to allow for negotiated agreements - meant that there was not a standard interpretation. Instead, direct negotiations between the combatants would determine the basis and practical elements of a peace plan. Nixon and Kissinger met with bipartisan congressional leadership on 27 November 1973, and during the meeting discussed the complicated nature of 242. Representative Samuel Stratton (D-NY) asked for Kissinger to explain its significance, to which he replied, "In the family - 242 doesn't mean a thing." Nixon quipped, "It means 1967 for the Arabs and for Israel it means what they have plus ten percent." Obviously annoyed, William Fulbright (D-AR) added, "It is not right to say 242 doesn't mean anything." But Nixon rightly pointed out, "It means 
different things to different people. To us it means what is negotiated." ${ }^{11}$ Indeed, the U.S. could work with the parties involved to come to some kind of agreement, but only as a third party. The precise details of an Israeli withdrawal had to be negotiated by the combatants. But Kissinger reminded the meeting that "a settlement has to cost Israel some territory. That is why we are for 242. It avoids our having to come down on one side or the other." ${ }^{12}$ Ultimately, the participants in the meeting all seemed to agree that Israel needed to make substantial territorial concessions in line with implementation of UN Resolution 242; however, the ambiguity of 242 caused concern.

While unwilling (and unable) to impose a settlement, American officials still articulated a working American position on the Arab-Israeli peace process in the aftermath of the 1973 war. A briefing paper for Kissinger, likely composed by Harold Saunders and William Quandt in preparation for Kissinger's trip to the Middle East in early November 1973, admitted that "U.S. interests require an Arab-Israeli peace settlement." ${ }^{13}$ But at the same time, "the United States has no interest at the outset of Arab-Israel peace negotiations in defining to others what we would consider reasonable final terms of an overall settlement ..."14 Thus, Kissinger and others recognized a tightrope needed to be walked - efforts had to be made to facilitate peace agreements, while not going so far as to impose an American peace plan on the belligerents.

\footnotetext{
11 "Bipartisan Leadership Meeting," 27 November 1973, Richard Nixon Presidential Library [hereafter, RNPL], National Security Council Files [hereafter, NSCF], Presidential/HAK MEMCONS, Box 1027, Folder - MEMCONS April-Nov 1973, HAK and Presidential [1 of 5].

12 Ibid.

13 “Briefing Paper, MAK Mideast Trip, Nov. 5-10, 1973. Subject: Middle East Negotiations,” RNPL, NSCF, Henry A. Kissinger Office Files, HAK Trip Files, Box 40, Folder - HAK Trip - Mideast, Islamabad, Peking, Tokyo, Seoul, Misc. and Memos, Nov. 5-16, 1973 [2 of 3], p. 1. Unfortunately, the briefing paper does not include an author. However, a separate document in the same folder - "Israeli and Egyptian Positions on Ceasefire and Disengagement Stage," November 3, 1973 - was written by Saunders and Quandt, which leads the author to think that perhaps Saunders and Quandt together authored the briefing paper for Kissinger that is referenced above, too. 14 Ibid.
} 
Nevertheless, the briefing paper also recognized that in the absence of a defined position on all issues, it was "useful to have some general principles in mind to serve as a standard against which to measure our strategy and tactic as negotiations proceed." In other words, although the U.S. could not stake out a definitive position on all the issues and force the belligerents to accept the agreement, the U.S. could still have a working idea of certain "principles" to help guide diplomacy. In principle, the U.S. supported "minimal territorial changes from the pre-June 5,1967, borders" matched by "maximum practical security arrangements for Israel, including the presence of Israeli forces in Arab sovereign territory during a transitional period in areas of particular importance to Israeli security; demilitarization of key areas; use of peacekeeping forces." Connected to that broad arrangement, Arab states would recognize and make peace with Israel, end the economic boycott against Israel, and establish "control over irregular forces operating from Arab territory." Additionally, a peace agreement would include "an Arab civic, religious and economic presence within a unified and open city of Jerusalem," as well as "freedom of navigation through the Suez Canal, Strait of Tiran, and Bab al-Mandeb." 15

The briefing paper offered some insight into the American position on Palestinian refugees. At the time, American officials supported a Palestinian autonomous arrangement with Jordan, rather than a separate Palestinian nation-state. According to the briefing paper, the U.S. aimed for "an equitable settlement of the Palestinian refugee problem, involving limited and controlled repatriation of some to Israel and generous compensation for resettlement and rehabilitation of the others." Regarding self-determination for Palestinians, the paper proposed "a political outlet for Palestinian political expression, to be worked out within a Jordanian-

\footnotetext{
${ }^{15}$ Ibid., p. 2.
} 
Palestinian framework and to include most of the West Bank and Gaza."16 The Palestinian Liberation Organization (PLO) sought to represent Palestinian interests, but according to Kissinger, "The idea of a Palestinian state run by the PLO was not a subject for serious discourse." $" 17$

Yet by not recognizing the legitimate aspirations of Palestinians for a separate nationstate, and by not recognizing the political authority of the Palestinian Liberation Organization (PLO), the American briefing paper revealed a fundamental flaw to the American position. As historian Paul Chamberlin has recently shown in his outstanding study of the PLO, high-ranking officials like Yasser Arafat had moderated their behavior and seemed ready to become engaged in peace discussions, if there was interest on the American side. But there was none from Kissinger. Chamberlin further suggests that in the aftermath of the 1973 war, the U.S. missed an opportunity to resolve the Arab-Israeli conflict by not considering a political solution apart from Jordan. ${ }^{18}$ A recent article in Diplomatic History discusses how the Nixon administration considered a "Palestinian option" before, during, and after Black September 1970. But ultimately the Administration favored the Jordanian option because, first, King Hussein indicated that Jordan would recognize the State of Israel, which Palestinian leadership consistently refused to do, and second, because Israel would not accept a separate Palestinian state while Palestinians would accept nothing less. ${ }^{19}$ Aside from U.S. domestic forces, refusing to engage Palestinian political representation outside of a Jordanian connection would have likely ensured the collapse

\footnotetext{
16 Ibid.

${ }^{17}$ Kissinger, p. 625

${ }^{18}$ Paul Chamberlin, The Global Offensive: The United States, the Palestine Liberation Organization, and the Making of the Post-Cold War Order (Oxford: Oxford University Press, 2012), 218-256.

${ }^{19}$ Simen Zernichow and Hilde Henriksen Waage, "The Palestine Option: Nixon, the National Security Council, and the Search for a New Policy, 1970,” Diplomatic History, Vol. 38, Issue 1 (2014), 182-209.
} 
of the peace process. But at the same time, engaging the PLO in no way ensured a peaceful comprehensive settlement to the conflict.

Importantly, the briefing paper argued that the U.S. needed to lead an effort to guide the combatants to a lasting peace settlement. The 1973 war had shifted the balance of power "somewhat in favor of the Arabs," which "loosened positions and provided some additional flexibility on procedural issues." Yet even in a changed atmosphere, "the parties will not go far down the negotiating road of their own accord." Therefore, after initial limited agreements, either the U.S. alone or the U.S. and USSR together needed "to reach certain judgments about the terms of a settlement and press them with the parties." That required "discussing with Israel at a fairly early date" the US position based on the principles outlined in the briefing paper, and that the US was prepared to support Israel within a certain context "to get the best deal possible." ${ }^{20}$

In order to pressure Israel to move forward with the peace process, as the paper noted, required firm domestic support. For one, the White House needed Congress on board. That meant engaging "key members of Congress" to "elicit their understanding and support. This will be particularly important as we will be seeking concessions which Israel will be reluctant to make and can expect Israel to seek to mobilize its supporters in Congress to bring pressure to bear on the administration." The administration also had to rally popular support, and "adopting a public posture that will help insure understanding of our objectives in American public opinion." 21

But in early November 1973, domestic support for the White House was hard to find. President Richard Nixon had been dogged with accusations related to the Watergate break-in and illegal activities of the Plumbers. During the summer months, the Senate Watergate Committee

20 “Briefing Paper ..." p. 13.

${ }^{21}$ Ibid., p. 18. 
conducted hearings, publicly broadcast on national television, which revealed Nixon had requested the installation of a tape recording device in the White House. Special Prosecutor Archibald Cox subpoenaed the tapes, but Nixon refused citing executive privilege. On 20 October, Attorney General Elliot Richardson and Deputy Attorney General William Ruckelshaus resigned from their positions rather than fire Cox (who was appointed by Richardson) on what came to be known as the Saturday Night Massacre; that same day, Kissinger flew to Moscow to work out a ceasefire to the 1973 war, and OPEC announced a full embargo on the US. ${ }^{22}$ Spiro Agnew, just weeks before, had resigned as Vice President amidst accusations of bribery and tax evasion. He was replaced by Gerald Ford; however, Ford was not officially sworn in until after his confirmation by the House on December 6. (The Senate confirmed Ford's appointment on November 27.) Thus, the Vice Presidency was technically vacant for nearly two months while Nixon steadfastly refused to release tapes that would likely lead to criminal charges against the President - all during a crucial period in American diplomatic involvement in the Middle East. Additionally, the Vietnam War continued to cast a long shadow over the White House, as South Vietnam had been in free-fall since U.S. troops were withdrawn in March 1973. In response to the disastrous denouement of the Vietnam War, which was clear by late 1973, Congress dramatically curtailed the President's ability to use American military forces abroad with passage of the War Powers Act on 7 November $1973 .{ }^{23}$ Congress easily overrode Nixon's veto of the War Powers Act. While American officials searched for a strategy that could potentially lead to a peace settlement in the Middle East, the credibility of the White House had fallen to perhaps its lowest point in American history.

\footnotetext{
${ }^{22}$ Daniel Yergin, The Prize: The Epic Quest for Oil, Money \& Power (New York: Free Press, 1991), p. 608.

${ }^{23}$ The War Powers Act prevents the President from deploying U.S. troops abroad for more than 60 days without congressional approval.
} 
The White House longed for international support, but was finding little among American allies. The economies of Western Europe and Japan were hurt worse than the U.S. by cuts in oil production since they relied more heavily on Middle Eastern oil. Although 1973 was supposed to be 'The Year of Europe' - an attempt to revitalize US-European alliances that had been strained by diverging national interests and the American war in Vietnam - by November 1973, the allies across the Atlantic had drifted farther apart.

Many U.S. allies in the Cold War sought distance Ii response to threats of oil cutbacks by OPEC. Japan issued a statement endorsing the Arab interpretation of UN Resolution 242 on 22 November, which was “Japan's first major split on foreign policy with the United States in the postwar era." In response, OPEC announced that Japan would not be included in the December production cuts. ${ }^{24}$ Most European governments, like France, “developed an independent strategy to secure their oil supplies via bilateral trade agreements with the producing countries." 25 Since 25 percent of Germany's oil supplies came from Libya, the potential loss of Libyan oil threated a severe economic crisis. Hoping to gain favor with Libyan leader Muammar Gaddafi, the German "government protested vehemently against shipments of American weapons from German ports to Israel" during the American resupply of Israel. ${ }^{26}$ The countries of the European Community issued a statement on 6 November that "supported a peace settlement on the basis of UN Resolution 242, thereby taking a pro-Arab stance demanding an Israeli withdrawal from the occupied territories."27 Less than two weeks later, OPEC announced that Europe would be excluded from December production cuts. ${ }^{28}$ Similar to what some commenters have called "Suez

\footnotetext{
${ }^{24}$ Ibid., p. 629.

${ }^{25}$ Rudiger Graf, "Making Use of the 'Oil Weapon': Western Industrialized Countries and Arab Petropolitics in 1973-1974,” Diplomatic History, Vol. 36, Issue 1, January 2012, p. 202.

${ }^{26}$ Ibid., pp. 202-203.

27 Ibid., p. 203.

${ }^{28}$ Ibid.
} 
in reverse," European powers were distancing themselves from the U.S. and its widely unpopular policies in the Middle East, a profound reversal of earlier situations when the U.S. sought to distance itself from unpopular European policies, like Suez in $1956 .{ }^{29}$

The oil embargo worsened an already-existing energy crisis. President Eisenhower had established a quota system on imported oil in order to protect domestic production. But by 1973, American domestic oil production was decreasing while consumption was reaching all-time highs. According to Daniel Yergin, during the early 1970s "the phrase 'energy crisis' began to emerge as part of the American political vocabulary. ${ }^{" 30}$ Electricity plants operated at nearcapacity and threatened brownouts or blackouts, and environmental concerns led to restrictions on coal burning. In April 1973, amidst ongoing energy concerns and a likely shortage of gasoline for the summer driving season, President Nixon abolished the quota system established by Eisenhower. ${ }^{31}$ The U.S., like Europe and Japan, looked to the Middle East and its large oil deposits as a way to satisfy energy needs. During the summer of 1973, U.S. imports had risen to 6.2 million barrels per day, up from 4.5 million per day in 1972 and 3.2 million in $1970 .{ }^{32}$ When OPEC unsheathed the oil weapon in October 1973, the U.S. was in a particularly vulnerable position.

The oil embargo "shocked" the international market and worsened a growing economic crisis in the US. In August 1971, the U.S. pulled out of the Bretton Woods Agreement which had served as the foundation for the postwar economic order. The U.S. had acquired massive debt due to the Vietnam War and Great Society programs, along with a reluctance of JFK or LBJ to raise taxes to account for such massive spending. This led to increased inflation and the

\footnotetext{
29 “The Year of Europe?” Foreign Affairs, January 1974, accessed online, 25 March 2015, http://www.foreignaffairs.com/articles/24476/z/the-year-of-europe.

${ }^{30}$ Yergin, p. 590.

${ }^{31}$ Ibid.

${ }^{32}$ Ibid., p. 591.
} 
overvaluation of the dollar. During the years of the Bretton Woods Agreement (1944 through the early 1970s), the dollar was pegged to the price of gold, and the world's major currencies pegged to the dollar. But the overvaluation of the dollar, along with dwindling gold supplies in the US and lack of confidence in the dollar abroad, forced the Nixon administration to float the dollar, meaning it would fluctuate based on market demand. As the value of the dollar continued to deteriorate, Americans were confronted with rising inflation and rising energy prices, while the economy had stagnated, creating what some have called, stagflation. Combined with domestic struggles were international market pressures from Western Europe and Japan, which also hastened the decline of the postwar boom in the United States. The oil embargo by OPEC exacerbated these existing conditions, and complicated the American effort to mediate the ArabIsraeli conflict.

Energy concerns and Watergate, two issues that plagued the Nixon administration, came together when Nixon met with Representatives Robert Steele (R-CT) and Louis Frey, Jr. (R-FL) on 29 November. The two had recently completed a trip to the Middle East on behalf of the House Foreign Affairs Committee, yet the message from the congressman was about domestic concerns. According to Steele, the people of New England were being hit hard by the oil embargo as $70 \%$ of heat and electricity in that region was made possible by oil. "We are in bad trouble," said Steele. But the President was in bad trouble, too, with Watergate threatening the integrity of the White House, and Nixon himself. Steele told Nixon, "Watergate is hitting Connecticut hard, but energy is trying to push it out." Nixon had to admit, "I know what a burden Watergate is." Understanding that the people of Connecticut - and presumably the American people writ large - were outraged by the President's unwillingness to cooperate with 
the Watergate investigation, Steele pointed out, "If you came to Connecticut on energy, you would not get that much on energy.",33

The White House was in such a tough spot that a newspaper editorial, likely from the Baltimore Sun, recommended using Vietnam to distract attention away from other problems! Specifically, the editorial suggested another Kissinger-Tho meeting about getting U.S. forces out of Vietnam because "it reminds this country that there is a world beyond the energy shortage, the Middle East conflict, and Watergate." 34

Thus, when Henry Kissinger traveled to the Middle East in early November 1973 to begin the American postwar diplomatic effort, he did so with a broad outline for the peace process, and with domestic and international challenges abounding. The primary purpose of his trip was to help negotiate an Israeli-Egyptian agreement to solidify the ceasefire and relieve pressure on the Egyptian Third Army. But more importantly, Kissinger aimed to use his trip to improve the status of U.S.-Arab relations and to create regional support for an American strategy that could lead to the implementation of UN Resolution 242, which meant the end of the ArabIsraeli conflict.

\section{Stepping Forward - Mending US-Arab Relations}

Henry Kissinger took his "first step on Arab soil" in Morocco on the evening of 5

November. Morocco was the first leg of his trip that included numerous stops in the Middle East and Asia as Kissinger sought to slowly implement a step-by-step approach to peace. Morocco

\footnotetext{
${ }^{33}$ Memorandum of Conversation, President Nixon, Steele, Frey, Timmons, and Scowcroft, 29 November 1973, RNPL, NSCF, Presidential/HAK MEMCONS, Box 1027, Folder - MEMCONS April-Nov 1973, HAK and Presidential [1 of 5].

${ }^{34}$ Diplomatic Cable from the Situation Room to Larry Eagleburger for Secretary Kissinger, 19 December 1973, RNPL, NSCF, Henry A. Kissinger Office Files, HAK Trip Files, Box 42, Folder - HAK Trip Europe \& Mideast Dec. 3-22, 1973, TOHAK 34-185 [1 of 2].
} 
was far enough removed from the immediacy of the Arab-Israeli conflict, yet close enough in order to influence member states of OPEC and leaders like Anwar Sadat. And importantly, Morocco enjoyed good relations with the United States.

Kissinger met with King Hassan II of Morocco that evening to discuss upcoming diplomacy. Kissinger told Hassan that the Nixon administration "needed about one month to organize our strategy in the U.S. and prepare our domestic situation.” Kissinger emphasized coming up with a strategy rather than a specific plan, and once that strategy was developed the U.S. "would move decisively." The King agreed to use his influence with OPEC to get the embargo lifted as soon as possible, but he warned Kissinger about the Palestinian refugee problem. According to Kissinger, the King said the Palestinians "were the joker in the deck. This issue was an aphrodisiac for the Arabs; no one would dare do anything against the Palestinians." Conversely, "if the U.S. could win the confidence of the Palestinians, then no Arab nation would fail to follow." 35

The U.S. had very little contact with the PLO. Yasser Arafat, Chairman of the PLO, had sent feelers to the U.S. through Iran and Morocco in July and September, hoping to establish a dialogue. He recognized that "Israel is here to stay," but also wanted the US to support the overthrow of King Hussein of Jordan. Many Palestinians regarded Hussein as an illegitimate ruler because the Hashemite Kingdom had been supported, and essentially propped up, by the British during the mandate period following WWI. During the mandate period, Britain severed Transjordan from Palestine and offered the throne of Transjordan to Abdullah I; his brother, Faisal I, was given the throne in Iraq. The Hashemite dynasty in Iraq ended with the violent overthrow of Faisal II in 1958; Arafat and the PLO had tried to remove Hussein from Jordan

\footnotetext{
${ }^{35}$ Henry A. Kissinger to General Scowcroft, Diplomatic Cable, 6 November 1973, RNPL, NSCF, Henry A. Kissinger Office Files, HAK Trip Files, Box 41, Folder - HAK Trip - Mideast, Islamabad, Peking, Tokyo, Seoul, HAKTO 1-60, Nov. 5-16, 1973 [1 of 2].
} 
during the Black September crisis in 1970, which ultimately led to the expulsion of the PLO from Jordanian territory. In 1973, Arafat hoped the U.S. would be willing to support Palestinian aspirations by forsaking its relationship with Hussein. According to Kissinger, Arafat informed the U.S. during the 1973 war that the PLO wanted "to participate in Arab negotiations with Israel; the 'score' it had to settle was with Jordan, not Israel."

But Kissinger had no interest in involving the PLO in what promised to be delicate negotiations. He informed Israeli Ambassador Simcha Dinitz that Arafat had asked "that we make Jordan dispensable. We will never agree to anything like that. ${ }^{{ }^{37}}$ Kissinger told Israeli Foreign Minister Abba Eban "our policy was based on Jordan, not the Palestinians." 38

In what Kissinger calls "the only significant communication to the PLO while I was in office," the US sent a message to the PLO through Morocco indicating that an American official was willing to meet with a representative from the $\mathrm{PLO}^{39}$ Lieutenant General Vernon A. Walters, then Deputy Director of the CIA (but in general, a versatile, go-to diplomat for the Nixon administration) met with "a close associate of Arafat's" on 3 November in Rabat, just two days before Kissinger arrived in Morocco. Per Kissinger's instructions, Walters communicated the U.S. positon regarding Palestinian refugees to be an inter-Arab concern, rather than an international concern. The U.S. supported Palestinian reconciliation with the Hashemite Kingdom, not its overthrow. The PLO representative, however, made it clear that "Palestinians could never live in a Hashemite state" and refused to articulate conditions under which the PLO

\footnotetext{
${ }^{36}$ Kissinger, p. 627

${ }^{37}$ Ibid.

${ }^{38}$ Ibid.

${ }^{39}$ Ibid.
} 
would recognize Israel. This initial meeting did not create a meaningful dialogue, and only one more meeting followed, which took place in March $1974 .{ }^{40}$

The U.S. briefly engaged the PLO just after the 1973 war, not to include it in the peace process, but to keep it pacified so that it did not try to undermine peace efforts during the early stages of Kissinger's diplomacy. By agreeing to meet with a PLO representative immediately before Kissinger traveled to the Middle East to explore potential peace initiatives, the U.S. ensured that the PLO would "be on its best behavior during the delicate early stages of our approaches to Egypt and while we were seeking Saudi support." ${ }^{41}$ Additionally, Kissinger regarded PLO interests as "incompatible with the interests of any of the parties to the Middle East conflict." Most problematic, the PLO refused to accept UN Resolution 242 or recognize the right of Israel to exist, which made negotiations practically impossible. Thus, Kissinger's diplomacy would discuss Palestinian refugees only in the context of a Jordanian-Palestinian arrangement, and presumably, only through official channels with Amman.

After leaving Morocco, Kissinger stopped briefly in Tunisia and then traveled to Egypt to meet with Egyptian President Anwar Sadat. While en route to Cairo, Kissinger learned that the European Community "had adopted a declaration on the Middle East strongly urging Israel's immediate withdrawal to the October 22 cease-fire line, and had thrown in a wholesale endorsement of the Arab interpretation of Security Council Resolution 242 for good measure." ${ }^{42}$ But as Kissinger noted, demanding Israel to withdraw to the cease-fire line of 22 October was no problem; however, linking that to a full Israeli withdrawal to the 1967 borders "was too ambitious to be achievable." ${ }^{\not 3}$ Of more immediate concern were the Egyptian Third Army and

\footnotetext{
${ }^{40}$ Ibid., pp. 628-29.

${ }^{41}$ Ibid., p. 627.

42 Ibid., p. 635.

${ }^{43}$ Ibid.
} 
the town of Suez, encircled by Israeli forces and cut off from supplies. Before moving forward with the peace process, efforts needed to be made to ensure the integrity of the ceasefire and safety of Egyptian forces and civilians.

Kissinger used the dilemma to his advantage as negotiations produced the first step in step-by-step diplomacy. Kissinger mediated a six-point agreement between Israel and Egypt that was signed on 11 November at Kilometer 101 along the road from Cairo to Suez. The agreement, usually called Kilometer 101, reaffirmed the ceasefire and allowed for the movement of nonmilitary supplies to the Egyptian Third Army and town of Suez, through UN checkpoint inspections, which included participation by Israeli officers. Along with defusing tensions, the Kilometer 101 agreement committed Israel and Egypt to return to the 22 October ceasefire lines "in the framework of agreement on the disengagement and separation of forces under the auspices of the UN." ${ }^{44}$ Implicitly, Israel and Egypt agreed to future disengagement even before negotiating the details to such agreements. Those negotiations would soon follow.

The agreement between Egypt and Israel revealed the strengthening relationship between Egypt and the U.S., which was a central goal of Sadat's foreign policy. After agreeing to the elements of the six-point plan, Sadat told the State Secretary, "Never forget, Dr. Kissinger. I am making this agreement with the United States, not with Israel." ${ }^{\prime 4}$ Sadat had kicked out Soviet advisers from Egypt in 1972 in the hopes of developing stronger ties with Washington. He sent President Nixon a note during the 1973 war that demanded immediate American involvement in the peace process, a dramatic overture considering Egypt had severed diplomatic ties with the U.S. during the 1967 war and never reestablished them. But Nixon reminded Sadat "that the only thing the United States could guarantee was that it was fully committed to advancing a process

\footnotetext{
${ }^{44}$ Ibid., p. 641.
}

${ }^{45}$ Ibid., p. 643. 
that would lead to a diplomatic agreement." Nixon made no promise about the nature of the agreement. ${ }^{46}$ Nevertheless, Kissinger regarded Sadat's move to the U.S. camp as a "breakthrough" because he "staked his policy on the American connection," thereby completing his move away from Moscow. ${ }^{47}$

Egypt and the United States agreed to resume diplomatic relations on 7 November 1973. Grasping for any kind of good news, Nixon hoped to deliver the message to the American people. In fact, Sadat and Kissinger had agreed "that the announcement would be made jointly at the White House and in Cairo.” But during a press conference, Kissinger was specifically asked if the United States and Egypt planned to resume diplomatic relations. "Mindful of Nixon's wrath but reluctant to lie," said Kissinger, "I squirmed and said nothing. Sadat had no such inhibitions. 'We will have news for you later in the day, be patient,' Sadat boomed, all but giving the game away." 48

After scoring success on the Egyptian-Israeli front, Kissinger traveled to Riyadh, Saudi Arabia, to meet with King Faisal, one of the most dependable friends of the United States, about the oil embargo and step-by-step diplomacy. While Saudi Arabia was arguably the most influential member of OPEC, its commitment to the Palestinian cause had long complicated relations with Washington. ${ }^{49}$ A cable from Alexander Haig to Kissinger explained that Nixon expected Kissinger to convince Faisal to lift the embargo and then allow the White House to make the announcement after his return to Washington. ${ }^{50}$ But Faisal was in no position to unilaterally lift an embargo that had been announced just two weeks before. The King admitted

\footnotetext{
${ }^{46}$ Yehuda Blanga, “The Russians are Coming, the Russians are Coming': American Management of the Crisis Associated with Ending the October 1973 War,” Middle Eastern Studies, Vol. 49, Issue 4, 2013, p. 569.

${ }^{47}$ Kissinger, p. 644.

48 Ibid.

${ }^{49}$ Maurice Labelle, Jr., "The Only Thorn: Early Saudi-American Relations and the Question of Palestine, $1945-$ 1949," Diplomatic History, Vol. 35, Issue 2, April 2011, p. 257-281.

50 Ibid., p. 657.
} 
that Saudi Arabia was in an "embarrassed" position because they valued the American friendship and certainly desired revenues from oil production; however, the King "needed some proof of tangible progress before a proposal to sheath the oil weapon could be put forward to the other Arab states." ${ }^{51}$ The answer to both the American and Saudi problems was step-by-step diplomacy.

King Faisal blessed Kissinger's diplomatic approach, thereby clearing a big hurdle in the Arab world. During a meeting that lasted several hours, King Faisal made it clear that Saudi Arabia supported a position very similar to the PLO - Israeli return of all land taken in the 1967 war, a right of return to all Palestinian refugees, and a mixed Jewish-Muslim state. Yet the King recognized that such a move could not happen immediately, and that movement towards peace was better than the current impasse. According to Kissinger, "when records were no longer being kept, yet in the hearing of other princes," King Faisal spoke highly of Kissinger's "ability and wisdom," and Kissinger suggests that Faisal called step-by-step diplomacy, "noble." Fearing that the Secretary did not get the message that Saudi Arabia supported step-by-step diplomacy, Prince Fahd reiterated the King's position. He thanked Kissinger for explaining the difficulties of the American position, and that "we appreciate the fact that things cannot be done overnight and have to be done step-by-step, but expeditiously." 52 The message was clear - Saudi Arabia supported a gradual move to a larger peace program, and as progress was made along that path, at some point the oil embargo would be lifted regardless of whether or not UN Resolution 242 had been fully implemented. The key was momentum.

In order to give the appearance of movement towards an undetermined broader peace plan, Kissinger planned to have a peace conference at Geneva in December. The purpose of the

${ }^{51}$ Ibid., p. 664.

${ }^{52}$ Ibid., p. 665. 
conference was to be ceremonial - a forum for the combatants to meet, air grievances, and move forward with disengagement agreements that would hopefully lead to peace. Although it was to be a multilateral conference, the "purpose was to use it as a framework for an essentially bilateral diplomacy." ${ }^{, 53}$ However, getting all the combatants to attend the conference was another matter. Syria was more interested in strengthening relations with the United States than with attending a peace conference, especially one that did not promise peace. Like Egypt, Syria had severed diplomatic relations with the United States during the 1967 war. But Syrian President Hafez al-Asad had expressed interest in establishing better relations. According to a sanitized copy of an intelligence document from 7 November, "the Syrians wish to establish immediately some sort of direct channel of communications with the American government." Both Asad and his Foreign Minister Abdul Khaddam were unhappy that Kissinger chose not to visit Syria during his trip in early November, and viewed the snub "as an indication that the United States does not take seriously the importance of Syria in the war and its necessary role in any settlement which is to emerge in the Middle East." In fact, Kissinger offered to have Assistant Secretary of State Joe Sisco visit Damascus during the trip, but that too was seen as a disrespectful move. Yet Syria was so interested in developing better relations that the Syrian Deputy Foreign Minister was instructed "to remain in the United States to be available to enter into direct discussions and, hopefully, a constructive dialogue with the American government." 54

This suited Kissinger very well because improving U.S.-Arab relations was a central element of step-by-step diplomacy. Regardless of whether or not Syria attend the ceremonial conference, its participation in step-by-step diplomacy was crucial. Moreover, Damascus had close ties with Moscow, and just as Sadat had moved his camp to the West, Kissinger hoped

\footnotetext{
${ }^{53}$ Ibid., p. 755.

${ }^{54}$ Untitled document ("Sanitized Copy"), 7 November 1973, RNPL, NSCF, Henry A. Kissinger Office Files, HAK Trip Files, Box 40, Folder - HAK Trip, Cairo-TS.
} 
Asad would do the same. The best way to "loosen" Syrian ties with the Soviet Union, according to Kissinger, was "by giving Damascus a stake in closer ties with the United States."

As he was trying to assemble the Geneva conference, Kissinger traveled to Damascus the first time a U.S. Secretary of State had visited Syria in 20 years - in order to establish closer ties and hopefully persuade Asad to attend the conference. ${ }^{56}$ He succeeded in the former, but not the latter. Kissinger admits he "developed a high regard for Asad," and U.S.-Syrian relations would enter into one of the few somewhat-bright periods of relations between the two states. But Asad would not attend a peace conference until a disengagement agreement with Israel was already completed. ${ }^{57}$

More significantly, though, Asad agreed to the concept of step-by-step diplomacy. He stated that although Syria would not attend the Geneva conference, "he would not oppose others' going to Geneva," which Kissinger regarded as "blessing the peace process and our strategy." 58 Without Syrian consent, step-by-step diplomacy was a non-starter. Yet even though Asad declined to attend the Geneva conference, he left open the possibility of a disengagement agreement with Israel as a step towards fulfillment of UN Resolution 242.

Like Kissinger, Asad had to navigate a complex domestic situation, which underlines the importance of domestic politics for state actors. Asad had risen to power within the Ba'athist Party in Syria, and seized power during a coup in November 1970. He was part of the military establishment that exercised power in the government, and while he was President and Prime Minister he still had to maintain the loyalty of the Syrian military and civilian population.

\footnotetext{
${ }^{55}$ Kissinger, p. 782.

56 Ibid., p. 777.

57 Ibid., p. 784.

58 Ibid.
} 
According to Kissinger, "it was clear that he did not possess the personal authority exercised by Sadat. I do not recall that Sadat ever mentioned domestic obstacles to his policies." ${ }^{59}$

Asad had a particular negotiating style that reflected his domestic political concerns, which simultaneously served to irritate Kissinger. In many instances, Asad started negotiations with only Kissinger and Kissinger's interpreter in order to determine "the lay of the land." After exploring Kissinger's position and determining his own flexibility for making demands or allowing for concessions, he would then bring in his closest associates, including military officials, and he and Kissinger would cover the same ground as in their private discussion. The advantage for Asad was that he never had to argue for a concession himself in front of other Syrian officials; instead, Kissinger had to press Asad for concessions, while the Syrian President could negotiate from a stronger position. For Kissinger, "it was effective domestic politics at the expense of many sleepless nights for me." 60

Domestic constraints went both directions, though. Kissinger told Khaddam "that the only way for us to proceed, given our domestic situation, is not to speak of a final settlement but to go step-by-step ... we must take this first step or we will never take the final step." ${ }^{61}$ Kissinger certainly remembered Rogers' misstep when he first tried to publicly outline the contours of a final settlement before beginning negotiations. ${ }^{62} \mathrm{He}$ also reminded Asad that "I'm in no position to make an agreement," and that "the best we can do is our best effort. We have not given any promise we can't keep." ${ }^{\prime 63}$

\footnotetext{
${ }^{59}$ Ibid., p. 780.

${ }^{60} \mathrm{Ibid}$.

${ }^{61}$ Ibid., p. 778.

${ }^{62}$ Both Spiegel and Quandt note that Kissinger recognized the downfalls of announcing a plan. Speigel, p. 281 and Quandt, pp. 131-132.

${ }^{63}$ Ibid., p. 784.
} 
Kissinger managed to convene a conference at Geneva on 21 December, under the auspices of the UN Secretary General, with the U.S. and USSR as co-chairs. Only Israel, Jordan, and Egypt attended the conference as Syria declined to attend and the PLO was not invited, leaving Jordan to speak for Palestinian rights. But a meeting of Arab heads of state in Algiers at the end of November declared the PLO to be the "sole" representative of the Palestinians. Additionally, Jordan did not fight in the 1973 war and therefore occupied an awkward position at a conference designed to bring together the combatants from the recent war, as well as diplomacy based on disengagement agreements. For a time it looked like Israel would not attend, either. Israeli officials indicated that they would not attend until Syria gave a list of Israeli POWs and allowed the Red Cross to tend to those prisoners. In fact, the Geneva conference was supposed to be held on 18 December but was postponed to 21 December in order to allow the Israeli cabinet more time to decide. Both Nixon and Kissinger pressured and pleaded with the Israelis to get them to join the conference, which they ultimately did. ${ }^{64}$

The Geneva conference was important for its symbolism, not its substance. The conference represented an American willingness to lead a diplomatic process that aimed for a lasting peace, and a willingness on the part of certain Arab leaders to move forward with the American plan. The conference was a venue for Kissinger to present his step-by-step approach, which he had done privately with a number of countries spanning North Africa, the Middle East, and the Persian Gulf, as well as the Soviet Union and Europe. Moreover, the conference furthered the cause of peace and lessened the risk of war simply by bringing Israel and Egypt together at a forum designed to symbolize the start of an American effort to negotiate small

\footnotetext{
${ }^{64}$ William B. Quandt, Peace Process: American Diplomacy and the Arab-Israeli Conflict since 1967 (Washington
} D.C.: Brookings Institution Press, 2005), pp. 138-141. 
political agreements as stepping-stones towards the eventual implementation of UN Resolution 242.

But the conference also revealed serious problems. Jordan's role in future negotiations would be limited at best, and excluding the PLO from the negotiating process undermined the legitimacy of Palestinian interests. Syria refused to attend, but agreed to pursue a disengagement agreement with Israel. Israel nearly avoided the conference altogether, and the Israeli political situation was in flux as Golda Meir's government was facing an election at the end of December. Only Sadat appeared satisfied with the status of the peace process and the prospects for moving forward. Soon after the conference, Egypt and Israel would complete a disengagement agreement that was another step towards a bilateral peace that would be realized at Camp David.

\section{U.S. Domestic Politics: Executive-Congressional Relations and the American Jewish Community}

Nixon and Kissinger tried to engage congressional leadership in order to rally domestic political support for the Administration's foreign policy in the Middle East. The two met with Senator Jacob Javits (R-NY) on 12 November to explain the Administration's actions during the 1973 war and hopes for moving forward. Javits was one of the leading pro-Israel voices in the U.S. Senate, and at times he acted as a go-between for the Administration and the American Jewish community, as well as Israel. Early on, Nixon pointed out that the United States was "the only country in the world supporting Israel. This doesn't mean Israel is wrong but that we must do our best to work out a settlement so one isn't forced on them. Without arms, Israel is finished." Nixon then added that American aid saved Israel, and Javits responded by saying, "Your standing in the Jewish Community is great," and stroked Nixon's ego by adding, "You 
personally saved Israel.” Both Nixon and Kissinger asked Javits to support the Administration's request of $\$ 2.2$ billion in emergency aid for Israel, which was still being considered by the Senate. Javits noted he had testified in support of the package. Beyond the Senate, too, Javits testified in support of the Administration - "I tell Israel the relations of conservative Republicans, and you, to Israel. I will fully cooperate.”65

Nixon hoped to use the largest-ever American aid package for Israel as a way to prepare for a looming recession. Yet he also wanted to avoid giving Israel too much military confidence so that it avoided peace negotiations. Roy Ash, Director of the Office of Management and Budget, informed Nixon that he expected "something of a recession in 1974." In order "to stimulate the economy" Nixon wanted to "put additional funds into the economy" and thought "Defense was the best place to do it." According to Brent Scowcroft, Nixon was reluctant to contribute to a fortress mentality in Israel and he recommended that "we should move cautiously in sending more supplies and equipment at the present time ... we may want to expedite shipments later on but right now he did not wish to build Israel up to enhance their intransigence." Additionally, Nixon appeared to be shaken by all of the challenges facing the White House. Scowcroft informed Kissinger that "the President has seemed irritable over the past few days and this afternoon looked very tired. He almost fell asleep during Schlesinger's briefing."

The Senate passed the emergency aid bill for Israel on 20 December, nine days after it cleared the House. The emergency aid was approved without amendments, despite the efforts of Senator William Fulbright (D-AR) and Representative Paul Findley (R-IL). While in the House,

\footnotetext{
${ }^{65}$ Memorandum of Conversation, Nixon, Kissinger, Javits, and Scowcroft, 12 November 1973, RNPL, NSCF, Presidential/HAK MEMCONS, Box 1027, Folder - MEMCONS April-Nov 1973, HAK and Presidential [1 of 5]. ${ }^{66}$ Brent Scowcroft to Henry Kissinger, 20 December 1973, RNPL, NSCF, Henry A. Kissinger Office Files, HAK Trip Files, Box 42, Folder - HAK Trip Europe \& Mideast Dec. 3-22, 1973, TOHAK 34-185 [1 of 2].
} 
Findley proposed an amendment that tied use of the bill's funds to implementation of UN Resolution 242. Findley hoped his amendment "would place the prestige of the House of Representatives behind fairness and evenhandedness as the basis of our Middle East policy." Unfortunately for Findley, the House rejected the amendment and passed the legislation to the upper chamber. Fulbright offered a stronger challenge to the bill as the Chairman of the Foreign Relations Committee, and he offered seven amendments "to lessen the political tilt of this bill." But the committee rejected all seven amendments, and three that were offered on the Senate floor were tabled. Fulbright called the emergency aid bill "ill-timed and ill-advised," and argued that the significance of the legislation was not the money, but rather the policy. "And that policy," said Fulbright, "is a short-sighted and imprudent one - promoting the military interests of Israel - when the circumstances require a policy furthering a peaceful settlement." Senator James Abourezk (D-SD), one of Fulbright's biggest supporters, agreed with the Democrat from Arkansas. He argued that the legislation authorized the Nixon Administration "license to continue its bankrupt policy of feeding the Middle Eastern flames with tanks and Phantom jets." Regardless of the arguments against the aid bill, the legislation received lopsided support in both chambers, easily passing, 364-52 in the House and 66-9 in the Senate. ${ }^{67}$

While Javits was sympathetic to the Israeli situation, he too emphasized the importance of creating stronger economic relations with Arab states. He referenced a three-year development plan for Jordan, based on $\$ 150$ million per year, and that "no one who has seen the traffic across the Allenby Bridge could fail to see the economic potential.” Elsewhere in the region, Javits mentioned that "Egypt was dissatisfied with the Soviet performance on the Aswan Dam. Egypt

\footnotetext{
67 "Aid to Israel Legislation Sails Through Congress," originally published in CQ Almanac 1973, 29 ${ }^{\text {th }}$ edition, Washington DC: Congressional Quarterly, 1974, 862-866. https://library.cqpress.com/cqalmanac/document.php?id=cqal73-1227756, accessed 3 April 2015.
} 
wants development. Our help can be a positive inducement." ${ }^{\prime 68}$ Interestingly Javits, a Republican, was proposing a development project for Egypt with American aid, an idea that seems better suited to a liberal program of the 1960s. But Javits recognized that American support for Arab development could lead to better relations between the U.S. and the Arab world, a stronger American presence in the region, and one that prevented an Egyptian backslide into the communist camp.

Nixon and Kissinger met with bipartisan congressional leadership on 27 November to lay out the Administration's plan for the peace process. Kissinger explained that the American plan was to woo moderate Arabs to work through the U.S. in order to get concessions from Israel, thereby decreasing the influence of the USSR and increasing the prestige of the United States. Regarding Israel, Kissinger argued that the Israeli position had been based on military supremacy, but after the 1973 war, "now know they can't do that." 69

In fact, Deputy Prime Minister Yigal Allon and Foreign Minister Abba Eban, two leftleaning moderates in the Meir cabinet, both publicly supported flexibility in negotiations in order to advance the peace process. ${ }^{70}$ The same day as the bipartisan meeting with the Administration, Eban delivered a speech to the Conference of Presidents of American Jewish Organizations and stressed, according to American documentation, that "Israel must undertake far-reaching conceptual reassessment" and to avoid being misled by "fringes of political spectrum" where "some illusions were sprouting."”1 By early January, "a public opinion poll showed that 82.8

\footnotetext{
${ }^{68}$ Ibid.

69 “Bipartisan Leadership Meeting,” 27 November 1973, RNPL, NSCF, Presidential/HAK MEMCONS, Box 1027, Folder - MEMCONS April-Nov 1973, HAK and Presidential [1 of 5].

${ }^{70}$ Memorandum from Harold Saunders and William Quandt to Secretary Kissinger, 30 November 1973, RNPL, NSCF, Harold H. Saunders Files/Middle East Negotiation Files, Box 1179, Folder - ME - 1973 Peace Negotiations, Nov. 28-30, 1973 [1 of 7].

${ }^{71}$ Diplomatic Cable from American Embassy in Tel Aviv to Secretary of State, 28 November 1973, RNPL, NSCF, Harold H. Saunders Files/Middle East Negotiation Files, Box 1179, Folder - ME - 1973 Peace Negotiations, Nov. $28-30,1973$ [1 of 7].
} 
percent of Israelis interviewed favored some territorial concessions for peace - an increase of 36 percent since November. The President underlined this and wrote 'okay' in the margin." 72

But from the perspective of the U.S. officials, the Israeli position was complicated by the activities of the American Jewish community. Senate Minority Leader Hugh Scott (R-PA) asked Kissinger on 27 November, "Are the Israelis more or less intransigent than American Jews?" Kissinger said, "Less ... Israel's position has evolved and they are willing to talk about things. But the American Jews are so tough and tend to hypo the Israelis and give them illusions." Senator William Fulbright asked, “Isn’t that an illusion?" Kissinger responded, "It is in this Administration." Fulbright shot back, "Not in Congress."”3

One senator in particular, Henry "Scoop" Jackson (D-WA), continued to be a thorn in the side of the White House. During Nixon's first term, Jackson had sponsored the amendment that authorized the President to sell up to $\$ 500$ million of military hardware on favorable credit terms to Israel. During Nixon's second term, Jackson took aim at détente (warming of relations between the U.S. and USSR). The Administration hoped to grant the USSR most favored nation (MFN) trade status in order to advance détente and increase American exports to a very large market during hard economic times. ${ }^{74}$ But the Soviet Union had imposed a "diploma tax" on anyone hoping to emigrate from the Soviet Union since they had received the benefits of public education. The tax was ostensibly to make up for costs of education, though in all likelihood it was meant to slow the "brain drain" from the Soviet Union, which included Soviet Jews. In response, Jackson sponsored an amendment (so-called Jackson-Vanik Amendment) that denied MFN status to any non-market economy (i.e., communist) that placed restrictions on emigration.

\footnotetext{
${ }^{72}$ Brent Scowcroft to Henry Kissinger, 11 January 1974, RNPL, NSCF, Henry A. Kissinger Office Files, HAK Trip Files, Box 43, Folder - HAK Trip Europe \& Mid East Jan 10-20, 1974, TOHAK 1-70 [2 of 3].

73 "Bipartisan Leadership Meeting," 27 November 1973, RNPL, NSCF, Presidential/HAK MEMCONS, Box 1027, Folder - MEMCONS April-Nov 1973, HAK and Presidential [1 of 5].

${ }^{74}$ The MFN status often includes low tariffs and high imports in order to strengthen economic ties.
} 
In doing so, the Cold War liberal hoped to undermine détente while further endearing himself to many in the American Jewish community and Israel, perhaps for another run at the White House in $1976 .{ }^{75}$

Jackson's efforts certainly got Nixon's attention. He told Scowcroft and Senator James McClure (D-ID), "I want the Cabinet out to kick Jackson in the tail. Jackson is trying to take all the heat off the Jews and put it on the Soviet Union ..." Furthermore, he reminded the two American officials that "the goal is ... a procedure that Israel will begin to withdraw from the occupied territories.. ${ }^{, 76}$ Nixon understandably regarded Jackson's efforts as going against the grain of the Administration's plan. Ultimately, Nixon did not have to sign the Jackson-Vanik Amendment into law, but only because he resigned the Presidency. His successor, President Ford, signed the bill in early January 1975; the Jackson-Vanik Amendment was recently repealed in 2012 .

Certain pro-Israel forces worried the Administration. Shortly before the Geneva conference, Kissinger sent word to the White House that he believed the "Jewish community" was attempting to "split him from the President," based on reports coming from the Israeli embassy. ${ }^{77}$ Senator Javits sent a message to Kissinger, warning him not to accept any invitations to see Jewish groups without first speaking with Javits, who claimed to have important information. ${ }^{78}$ Kissinger agreed to "not plan a program or meetings with Jewish leaders without

\footnotetext{
${ }^{75}$ For a discussion of the Jackson-Vanik Amendment, see Bard, pp. 65-90.

${ }^{76}$ Memorandum of Conversation, Nixon, McClure, and Scowcroft, 18 December 1973, RNPL, NSCF, Presidential/HAK MEMCONS, Box 1027, Folder - MEMCONS December 1973, HAK and Presidential [1 of 2]. ${ }^{77}$ Diplomatic Cable, Eagleburger to Scowcroft HAKTO 49, 16 December 1973, RNPL, NSCF, Henry A. Kissinger Office Files, HAK Trip Files, Box 42, Folder - HAK Trip Europe \& Mideast Dec. 8-22, 1973, TOHAK 1-88 [2 of 2].

${ }^{78}$ Diplomatic Cable, Eagleburger to Scowcroft, 11 December 1973, RNPL, NSCF, Henry A. Kissinger Office Files, HAK Trip Files, Box 42, Folder - HAK Trip Europe \& Mideast Dec. 8-22, 1973, TOHAK 1-88 [1 of 2].
} 
first seeking the Senator's advice." ${ }^{, 79}$ In response, Javits sent word that he was "concerned that other elements of the Jewish community might get their noses out of joint because this group would be only a partial representation of the elements which you need to contact." Furthermore, Javits recommended that Kissinger "survey carefully all the elements of influence in the Jewish community in this area and then make your contacts with them on a carefully planned basis." ${ }^{\prime 80}$ Javits and Kissinger both recognized that the Jewish community wielded a significant degree of power, and Scowcroft agreed "to make no dinner engagements for Jewish groups without further word from you." ${ }^{" 1}$

When Kissinger met with a group of leaders within the American Jewish community on 27 December, he argued that Israel needed to take advantage of the situation to eventually move towards full peace agreements in exchange for land. The meeting included some of the most influential members of the American Jewish community - Max Fisher (major Republican Party fundraiser), Jacob Stein (President of the President's Conference [NY]), Arthur Hertzberg (President of the American Jewish Congress), Rabbi Israel Miller (Zionist Federation of America), Herman Weisman (President of the Zionist Organization of America), Daniel Bloomberg (President of B'nai B'rith), along with several other leading figures. Kissinger told the group that "the Yom Kippur war was a disaster for Israel," and that Israel no longer enjoyed a decisive military advantage. The international community - not just the Soviet Union, but Europe and Japan as well - were lining up against the Israeli position. "Our strategy now will gain time," said Kissinger, "if it works.” But Kissinger also said, "I won’t kid you - Israel must

\footnotetext{
${ }^{79}$ Diplomatic Cable, London HAKTO 18 to Eagleburger, 13 December 1973, RNPL, NSCF, Henry A. Kissinger Office Files, HAK Trip Files, Box 42, Folder - HAK Trip Europe \& Mideast Dec. 8-22, 1973, TOHAK 1-88 [1 of 2].

${ }^{80}$ Diplomatic Cable, Scowcroft to Kissinger, 13 December 1973, RNPL, NSCF, Henry A. Kissinger Office Files, HAK Trip Files, Box 42, Folder - HAK Trip Europe \& Mideast Dec. 8-22, 1973, TOHAK 1-75 [1 of 2]. ${ }^{81}$ Ibid.
} 
make sacrifices. It is the condition of its survival. I guarantee you, if Israel continues to stay on the October 6 borders, in ten years it will be bled to death or destroyed." 82

Kissinger revealed one of the central purposes of step-by-step diplomacy in the meeting to shield Israel from external pressures in order to give Israel time to prepare itself to move forward with a substantial land-for-peace exchange. Importantly, step-by-step diplomacy was not designed to keep Israel in the occupied territories; it was designed to give Israel an opportunity to get out. Kissinger regarded a significant Israeli withdrawal as vital to Israeli security. Although the exact nature of the Israeli withdrawal was undefined, Kissinger implied that the withdrawal should be significant.

\section{Stepping Forward?}

In early November, Kissinger and Sadat had agreed that an Egyptian-Israeli disengagement agreement was going to be the first significant step of the resurrected peace process following the 1973 war. Egypt and Israel reached an agreement at Kilometer 101 in November, which allowed for the release the Egyptian Third Army. But a formal disengagement agreement was to be the more substantive start of the peace process.

Kissinger used 'shuttle diplomacy' to negotiate a disengagement agreement between Israel and Egypt, called Sinai I, on 18 January $1974 .{ }^{83}$ He traveled to the Middle East on 11 January after receiving positive signals from both Israel and Egypt, and with a broad outline for

\footnotetext{
${ }^{82}$ Memorandum of Conversation, Henry Kissinger, Max Fisher, et al, 27 December 1973, Kissinger Transcripts in Proquest-Chadwyck's Digital National Security Archive, accessed 30 June 2014. B'nai B'rith is one of the oldest Jewish international organizations. It seeks to advance the security of the Jewish state and combat antisemitism. ${ }^{83}$ Kissinger would 'shuttle' between Middle East capitals to negotiate with heads of state and negotiating teams, serving as an intermediary between two parties. He used shuttle diplomacy to negotiate a ceasefire to end the Yom Kippur War, and then for all three disengagement agreements. This feature of his personal style of diplomacy is often mentioned in connection with step-by-step diplomacy, but the two are separate ideas. The former involves his movement between cities on behalf of other parties, while the latter refers to his diplomatic method for resolving the Arab-Israeli conflict.
} 
the disengagement already in place. Golda Meir's Labor Alignment coalition managed to hold onto power after a strong challenge from the newly-formed Likud Party during the 31 December Knesset elections, which made the Israeli position more stable. According to Kissinger, the Israeli government had promised to submit a disengagement proposal immediately after the elections. ${ }^{84}$ After shuttling for about a week, Kissinger managed to get the two sides to agree to a reduction in force levels and a more substantial disengagement of military forces; a UN buffer zone would fill-in between Israeli and Egyptian forces on the east side of the Suez Canal. The agreement was signed at Kilometer 101.

American officials expected the oil embargo to be lifted after the Sinai disengagement agreement. During the January negotiations, Sadat repeatedly told Kissinger (who then told Nixon) that he would personally make an effort to convince OPEC to lift the embargo on the United States after reaching an agreement with Israel. Soon after Sinai I, Sadat even assured Kissinger that he would have the embargo lifted within one week. Nixon, of course, hoped to deliver good news to the American public and planned to make the announcement during his upcoming State of the Union address. But Kissinger informed Scowcroft that that was not a good idea because the announcement from an American President gave the "oil weapon" more legitimacy and made its future use more likely, which Kissinger fails to mention in his memoirs. ${ }^{85}$ Therefore, Kissinger actually gave Sadat the "suggested" text he was to use when announcing to the world the end of the oil embargo, including explicit recognition of the pivotal

\footnotetext{
${ }^{84}$ Kissinger, p. 800 .

${ }^{85}$ At the bottom of page 892 in Years of Upheaval, Kissinger claims - based on a diplomatic cable that he includes in Upheaval - that the reason he discouraged Nixon's announcement was to appease the Saudis. For some reason he failed to mention that, according to the actual cable itself, he feared that such an announcement "will give strength to the Arabs in their determination to deal with us harshly. We may get the oil embargo removed for the moment, but you can be sure it will be reimposed [sic] the first time we take a position inimical to Arab interests." Diplomatic cable, Kissinger to Scowcroft, 20 January 1974, RNPL, NSCF, Henry A. Kissinger Office Files, HAK Trip Files, Box 43, Folder - HAK Trip Europe \& Mid East Jan 10-20, 1974, TOHAK 1-65 [2 of 2].
} 
role played by President Nixon. ${ }^{86}$ The proposed announcement began, "The President of the United States has clearly demonstrated his deep commitment to a just and permanent peace in the Middle East." $\$ 87$

But to the consternation of the Administration, the embargo continued. Syria, a non-oil producing state, was the primary reason why. King Faisal had effectively given a "veto to states with unsatisfied claims," and on 21 January, President Asad demanded that the oil weapon be used on Syria's behalf, similar to Egypt. ${ }^{88}$ In other words, Asad wanted movement towards a peace agreement before he would consent to lifting the oil embargo. That convinced Kissinger to take an exploratory shuttle to Syria in February in order to start making progress towards a Syrian-Israeli disengagement agreement. A month later - and two months before the actual agreement itself - the oil embargo was lifted on 18 March 1974.

Nixon tried to convince King Faisal that the U.S. planned to push hard for a substantial Israeli withdrawal, and that lifting the embargo was necessary to achieve that goal. In a letter, Nixon reminded Faisal of his State of the Union address, during which he "committed the United States to an active role in helping to achieve a just and durable peace in the Middle East on the basis of full implementation of Security Council Resolutions 242 and 338 and stated that the Egyptian-Israeli disengagement agreement was the first step in this process." ${ }^{99}$ The next day Nixon sent word to Faisal through Ambassador James Akins reiterated that message. "I will not be swayed by domestic political considerations," said Nixon. "I recognize that the government did not do enough in the Middle East during my first term but I am determined now that the

\footnotetext{
${ }^{86}$ Diplomatic cable, Kissinger to Scowcroft, 19 January 1974, RNPL, NSCF, Henry A. Kissinger Office Files, HAK Trip Files, Box 43, Folder - HAK Trip Europe \& Mid East Jan 10-20, 1974, TOHAK 1-65 [2 of 2].

${ }^{87}$ Diplomatic cable, Kissinger to Scowcroft, 20 January 1974, RNPL, NSCF, Henry A. Kissinger Office Files, HAK Trip Files, Box 43, Folder - HAK Trip Europe \& Mid East Jan 10-20, 1974, TOHAK 1-65 [2 of 2].

${ }^{88}$ Kissinger, p. 893.

${ }^{89}$ Nixon to Faisal, 7 February 1974, RNPL, NSCF, Henry A. Kissinger Office Files, Country Files - Middle East, Palestinians to Secretary Kissinger's Trip to the Middle East, November 5-10, 1973, Box 139, Folder - NSCF: Country Files: Middle East, Saudi Arabia (2 of 3), [Dec 73 - Feb 74] (2 of 3).
} 
Middle East be settled." But Nixon argued that he needed the embargo lifted to lessen domestic pressures. In particular, "Congress and the press will make it extremely difficult for me to make progress ... I am out on a limb - I have been there before - but I want us to be able to work together for a settlement." 90

Kissinger pushed the Israelis. Near the end of his January trip, he met with moderate Israeli officials, including Yigal Allon, Abba Eban, and Simcha Dinitz, and encouraged Israel to move forward with a more comprehensive peace plan. After suggesting that dealing with Hussein was likely better than dealing with Arafat, Kissinger offered his assessment: "I thought at the end of October you were in bad shape politically. I think now you have an extraordinary chance. You can deal with each of these countries separately and give each of them something they want, and they will never get together again." 91 Although he did not go into specific details the message was clear - Kissinger was pushing Israel to use the opportunity presented by stepby-step diplomacy to move bilaterally in a way that dealt comprehensively with all the details.

But the Israeli position, like the American position, was complicated by domestic politics. Prime Minister Meir refused "to consider a national unity government including Likud, reportedly describing that prospect as a 'disaster' for Israel as it would block negotiating prospects and threaten Israel's positive relations with the U.S."92 A month earlier, Likud leader Menachem Begin had criticized the Sinai I agreement and warned the fragile Israeli government

\footnotetext{
${ }^{90}$ Scowcroft to Akins, 8 February 1974, RNPL, NSCF, Henry A. Kissinger Office Files, Country Files - Middle East, Palestinians to Secretary Kissinger's Trip to the Middle East, November 5-10, 1973, Box 139, Folder - NSCF: Country Files: Middle East, Saudi Arabia (2 of 3), [Dec 73 - Feb 74] (2 of 3).

${ }^{91}$ Memorandum of Conversation, Kissinger, Allon, Eban, Dinitz, et al., 20 January 1974, RNPL, NSCF, Henry A. Kissinger Office Files, Country Files - Middle East, Middle East HAK Trip December 1973 Miscellaneous Papers to JORDAN June 1974 The President, Box 140, Folder - NSCF: Country Files: Middle East, Sec. Kissinger's Middle East Trip Jan 11-20, 1974 (2 of 2)[2 of 2].

${ }^{92}$ Likud is the conservative, right-wing party in Israel that formed after the 1973 war, and eventually unseated the Labor Party in the 1977 elections, which was the first time that the political left was defeated in Israel. Memorandum for Secretary Kissinger from The Situation Room, 26 February 1974, RNPL, NSCF, Henry A. Kissinger Office Files, HAK Trip Files, Box 44, Folder - HAK Trip Mid East \& Europe TOHAK 1-50, Feb 25 Mar 4, 1974 (2 of 2).
} 
against entering into long-term agreements that were based on Israeli withdrawals. ${ }^{93}$ The role of the National Religious Party, traditionally aligned with the Labor Party, added to the rightward drift in Israeli politics. Following the 1967 war, the National Religious Party sought to hold onto the lands of Greater Israel, especially Judea and Samaria, which made up the West Bank. According to Meir, "the entire right wing had now combined into a bloc of its own. A coalition would have to be formed again, and it would clearly be a back-breaking job to form it, since the religious bloc, which was a traditional coalition partner of ours, was itself deeply divided on the question of who should lead it and what its policy should be at this tremendously difficult time." ${ }^{\circ 4}$ The hardline shift in Israeli political culture convinced Shimon Perez and Moshe Dayan to not take part in the Cabinet, even after personal pleas by Meir. Therefore, Meir was forced to form a minority government that, according to an American intelligence report, "would be able to make the necessary decisions concerning a disengagement with Syria. After that, however, the decisions on a broader settlement are expected to be more difficult." 95

Negotiating an agreement between Israel and Syria - "two mortal enemies," according to Kissinger - promised to be more difficult than negotiating an Israeli-Egyptian disengagement. ${ }^{96}$ Historically, Palestine had been a part of Greater Syria. But the European mandate system following WWI led to the separation of Palestine from Syria and trans-Jordan from both Palestine and Syria. Thus, many Syrians viewed Israel as an illegitimate state that usurped a Palestinian state, which itself was an illegitimate creation of the European nation-state model.

\footnotetext{
${ }^{93}$ Reportage, Comment on Signing of Disengagement Agreement, "Likud Against Speedy Agreement," 17 January 1974, RNPL, NSCF, Henry A. Kissinger Office Files, Country Files - Middle East, Middle East HAK Trip December 1973 Miscellaneous Papers to JORDAN June 1974 The President, Box 140, Folder - NSCF: Country Files: Middle East, Sec. Kissinger's Middle East Trip Jan 11-20, 1974 (2 of 2)[1 of 2].

${ }^{94}$ Kissinger, p. 937. Taken from Meir's autobiography - Golda Meir, My Life (New York: G. P. Putnam's Sons, 1975), p. 455.

${ }^{95}$ Memorandum for Secretary Kissinger from The Situation Room, 26 February 1974, RNPL, NSCF, Henry A. Kissinger Office Files, HAK Trip Files, Box 44, Folder - HAK Trip Mid East \& Europe TOHAK 1-50, Feb 25 Mar 4, 1974 (2 of 2).

${ }^{96}$ Kissinger, p. 935.
} 
From the Israeli side, Syria was seen as the most militant Arab neighbor that was determined to demolish the infant Jewish state. Therefore Kissinger expected difficult negotiations, and he got what he expected.

Kissinger used his February shuttle to tentatively establish a negotiating base for a disengagement agreement. In return for a list of Israeli prisoners of war, Asad agreed to consider a "serious" Israeli proposal. But at the time, the Meir government hoped to disengage forces only in territory taken in the $1973 \mathrm{war}$ - not territory taken in 1967. Kissinger figured the Israeli proposal would only anger Asad and potentially derail negotiations before they really started, so he actually declined to give Asad the details of the proposal. Instead, Kissinger suggested that Syria could expect "a bit" of territory lost in 1967, but that Israel was not prepared to dismantle any settlements in the Golan. While Kissinger was shuttling, Syria and Israel exchanged daily artillery fire across the ceasefire lines. ${ }^{97}$

Aside from tough negotiations between enemy states, Nixon and Kissinger continued to face challenges from Scoop Jackson and the American Jewish community. Jackson pressed forward with his effort to link MFN status for the Soviet Union to freedom of emigration. From the perspective of the Administration, Jackson's effort was troublesome because American diplomacy had already severely diminished Soviet involvement in the peace process. As Kissinger said in a meeting with GOP congressional leadership, "We can't frustrate them in every area." As for the "Jewish community," according to Nixon, "They are worse than Jackson." The President wondered, "Isn't it better for the U.S. to have influence with its enemies than the Soviet Union? Israel says all it needs is weapons." ${ }^{98}$ Nixon's comments reflected a

\footnotetext{
${ }^{97}$ Spiegel, pp. 276-277.

${ }^{98}$ Memorandum of Conversation, Nixon, Kissinger, Scowcroft, and GOP Congressional Leadership, 8 March 1974, RNPL, NSCF, Presidential/HAK MemCons, Box 1028, Folder - MemCons - HAK \& Presidential, March 1-May8, 1974 [3 of 4].
} 
similar Saudi concern - that Israel was interested in undermining the "American-Arab

rapprochement." In particular, the Saudis were incensed by Meir's declaration in early February that Israel will "never give up Golan."99

The Administration continued to stress the importance of improved American-Arab relations. In a meeting with congressional leadership on 24 April, Nixon told the meeting, "We are at a watershed period in foreign policy, in a period when often we are tied exclusively to Israel. We are now developing a relationship of friendship with the whole area. It's not to get the Soviet Union out - that is self-defeating - but to have us in." Kissinger pointed out that the Administration was requesting $\$ 250$ million in aid for Egypt, and $\$ 100$ million in a contingency fund that could be used for Jordanian and Syrian projects. He also noted that he had informed the Israelis that the US needed to support Egypt because Sadat no longer relied on the Soviets, and that he was going to make that point "with the American Jewish leaders," too. Nevertheless, Nixon pointed out that the American Jewish community continued to present problems. According to Nixon, "the most unreasonable people supporting Israel are not their government, but the American Jewish community." To help mute domestic criticisms, Kissinger indicated that of the $\$ 2.2$ billion package for Israel in late 1973 , Nixon planned to give $\$ 1$ billion in grants and $\$ 1.2$ billion in credits, rather than $\$ 2.2$ billion in only credits; another $\$ 500$ million in credits was to be allocated "after a continuation of the negotiation." 100

As Kissinger prepared to begin another round of shuttle diplomacy, hopefully ending in a disengagement agreement between Syria and Israel, the Israeli political scene took a dramatic turn. Golda Meir resigned as Prime Minister on 11 April 1974. After finally convincing Dayan

\footnotetext{
${ }^{99}$ Diplomatic Cable, American Embassy in Jidda to Secretary of State, 12 February 1974, RNPL, NSCF, Country Files - Middle East, Box 631, Folder 1.

${ }^{100}$ Memorandum of Conversation, Nixon, Ford, Kissinger, Scowcroft, and Congressional Leadership, 24 April

1974, RNPL, NSCF, Presidential/HAK MemCons, Box 1028, Folder 4.
} 
and Peres to join her cabinet, the Agranat Commission, set up to investigate the intelligence failures leading up to the 1973 Arab-Israeli war, released its first report on 2 April. The report singled out Chief of Staff General David Elazar as bearing “direct responsibility,” and his superior - Defense Minister Moshe Dayan - would have been the next target. Feeling the tide turning against her, Meir tendered her resignation and agreed to lead a caretaker government until a successor was chosen. ${ }^{101}$ Yitzhak Rabin, former Chief of Staff and Ambassador to Washington, officially became Prime Minister on 3 June 1974, only three days after Israel announced it had reached a disengagement agreement with Syria.

The path to reaching a disengagement agreement was a rocky one, not only between Israel and Syria, but between the US and Israel, too. While Nixon periodically floated the idea of freezing aid, Kissinger first brought up the idea during the Syrian shuttle. Shortly after arriving in the Middle East, Kissinger sent a message to Scowcroft with a particular request - "I must be assured of the President's support if the Israelis should reject our position," said Kissinger. "We may even have to threaten the Israelis with a cutoff of our aid. You should confirm with Haig that I can count on the President's support for such measures and advise me." 102 Nixon was only too ready to support Kissinger's position, which Kissinger must have expected. Nixon sent a letter to Meir on 4 May, warning her that Israel should not try to jeopardize U.S. peace efforts in the region, and that the US may have to reexamine its relationship with Israel. ${ }^{103}$ In doing so, Nixon foreshadowed Ford's decision the next March to freeze aid shipments to Israel and reassess U.S.-Middle East policy. On 10 May Nixon sent word to Kissinger through Scowcroft that "he fully supported your tough stance with the Israelis and that you should know that his

\footnotetext{
${ }^{101}$ Kissinger, p. 1039.

${ }^{102}$ Diplomatic Cable for General Scowcroft from the Secretary, 1 May 1974, RNPL, NSCF, Henry A. Kissinger Office Files, HAK Trip Files, Box 45, Folder - HAK Trip MidEast HAKTO 1-179, Apr. 28-May 31 , ’74 [2 of 4]. 103 Quandt, p. 149.
} 
support for continued aid to Israel, also in the event of any new hostilities, is full conditioned on their taking a reasonable posture in your present negotiations." Nixon also offered to write Meir another letter, if Kissinger felt that would help. ${ }^{104}$

Kissinger blamed Israeli intransigence in negotiations on four factors - "domestic divisions in Israel"; "a deliberate attempt to wreck our Arab policy"; "Israeli assessment of presidential paralysis - the last message from the President brushed off with disdain by the PM"; and "Israeli apparent belief that they have established a direct pipeline to the Pentagon." While Kissinger felt that the first three factors had to be dealt with after his current shuttle, the final factor could be handled immediately. He therefore instructed Haig to get in touch with Defense Secretary Schlesinger and have him "hold up all new commitments. Also delay administratively all pipeline items. We can then review the entire situation after my return.”105

Nixon's reply, consistent with many Nixon venting sessions about the Israelis, again supported Kissinger's position. Scowcroft messaged Kissinger later on 14 May about a call he had with Nixon. According to Scowcroft, Nixon "called again to say that he wanted by the end of the day a listing of all forms of aid to Israel which were under his authority to terminate. He said to tell you that you should make it unmistakably clear, if you reach that point, that the Israelis will be immediately shut off completely, without a nickel." ${ }^{106}$ The message echoed two similar messages from the day before. A Nixon phone call for Scowcroft led to a Scowcroft message for Kissinger, which related that Nixon intended to "cut off every bit of aid to Israel

\footnotetext{
${ }^{104}$ Diplomatic Cable for Henry A. Kissinger from Brent Scowcroft, 10 May 1974, RNPL, NSCF, Henry A. Kissinger Office Files, HAK Trip Files, Box 46, Folder - HAK Trip MidEast; Apr. 28-May 31, 1974, HAKTO $76-$ 160 [1 of 2].

${ }^{105}$ Diplomatic Cable for General Scowcroft to Sec Kissinger HAKTO 87, 14 May 1974, RNPL, NSCF, Henry A. Kissinger Office Files, HAK Trip Files, Box 45, Folder - HAK Trip MidEast HAKTO 1-179, Apr. 28-May 31, '74 [3 of 4].

${ }^{106}$ Diplomatic Cable from Scowcroft to Bremer/Rodman for Sec. Kissinger, 14 May 1974, RNPL, NSCF, Henry A. Kissinger Office Files, HAK Trip Files, Box 47, Folder - HAK Trip MidEast HAKTO 161-245, Apr. 28-May 31, 1974 ( 2 of 2$)$.
} 
under his authority" if negotiations failed. Furthermore, Nixon added that the disengagement between Syria and Israel "was not the end of the line but merely a step toward a permanent settlement in which we would support them for a full solution to the problem." ${ }^{\prime 107}$ Later that day, Scowcroft informed Kissinger of another Nixon phone call, during which he again mentioned that he planned to cut off all aid to Israel if negotiations broke down. ${ }^{108}$

While the Israeli situation bedeviled the Nixon Administration, a powerful pro-Israel organization took aim for Henry Kissinger in an effort to discredit him and undermine the American-led peace effort. Herman Edelsberg, Executive Director of the International Council of B'nai B'rith, sent a confidential memorandum to the "Board of Governors" on 7 May 1974, which discussed "Tasks Confronting B'nai B'rith." ${ }^{109}$ Such documents are difficult to come across, and this one seems to brag about the power of pro-Israel organizations and their ability to influence U.S. policy. Whether or not the document accurately reflects the power of an organization like B'nai B'rith is hard to say. But Arkansas Senator William Fulbright, who received the memorandum from Norman Dacey, Chairman of The American Palestine Committee, called it "quite a remarkable document." "110

The document stressed the importance of continued military support from the United States. According to Edelsberg "Recent events have shown that selective and measured pressure in decision-making areas of the U.S. Government can induce the desired results. As B'nai B'rith activists, it is our duty to maintain that pressure to secure the greatest possible U.S. support for

\footnotetext{
${ }^{107}$ Scowcroft to Bremer/Rodman for Henry A. Kissinger, 14 May 1974, RNPL, NSCF, Henry A. Kissinger Office Files, HAK Trip Files, Box 47, Folder - HAK Trip MidEast HAKTO 161-245, Apr. 28-May 31, 1974 (2 of 2).

${ }^{108}$ Scowcroft to Bremer/Rodman for Secretary Kissinger, 13 May 1974, RNPL, NSCF, Henry A. Kissinger Office Files, HAK Trip Files, Box 47, Folder - HAK Trip MidEast HAKTO 161-245, Apr. 28-May 31, 1974 (2 of 2).

${ }^{109}$ The document was included in a letter from Mr. Norman F. Dacey to J. William Fulbright on 21 February 1977, Herman Edelsberg to Board of Governors, 7 May 1974, Tasks Confronting B'nai B'rith, Box 15, Series 2 Foreign Relations, Folder 3, MS 144-C, Middle East, 1977, J. William Fulbright Papers, University of Arkansas.

${ }^{110}$ Mr. Norman F. Dacey to J. William Fulbright on 21 February 1977, Box 15, Series 2 Foreign Relations, Folder 3, MS 144-C, Middle East, 1977, J. William Fulbright Papers, University of Arkansas.
} 
Israel's needs." 111 But Edelsberg was worried that "the whole concept of foreign aid is coming under increasingly critical review throughout the country." In fact, Edelsberg recognized that the Pentagon was already concerned about the effects of supplying Israel with American military support, indicative of the organization's ability to access information from within the U.S. government: "Here the International Council draws your attention to its recent report on complaints within the Pentagon that the diversion of arms to Israel has already weakened the effectiveness of U.S. combat units. We intend soon to present detailed proposals for countering this new and dangerous current of military opinion." 112

The memorandum clearly indicated the willingness and ability of a pro-Israel organization to attack Nixon and Kissinger in an effort relieve pressure being placed on Israel through step-by-step diplomacy. According to Edelsberg,

Examples of the political success that the type of pressure mentioned above can achieve may be drawn from the Watergate scandal. B'nai B'rith can claim to have contributed to a situation in which the early ouster of President Nixon from the White House looks assured. The strong likelihood that Vice President Ford will succeed to the Presidency offers us new opportunities of more actively influencing U.S. policy in the Middle East, as well as on the whole range of issues that concern American Jewry. Indeed, the prospective President's "open mind" on foreign affairs may provide something of a blank sheet on which to impress our views. Nevertheless, we are still confronted by obstacles, and we must plan carefully in advance so as to place ourselves in a position to remove them or to soften their resistance. ${ }^{113}$

Step-by-step diplomacy, in particular, was seen as a major threat. "In the view of the International Council," wrote Edelsberg, "the chief of these obstacles is the present course of U.S. foreign policy, the brain child of Dr. Kissinger." In order to counteract Kissinger's diplomacy, the International Council recommended following one of two courses - either pressure Kissinger directly to get him "to change course," or try "to undermine the prestige he

\footnotetext{
${ }^{111}$ Herman Edelsberg to Board of Governors, 7 May 1974, Tasks Confronting B'nai B'rith, Box 15, Series 2 Foreign Relations, Folder 3, MS 144-C, Middle East, 1977, J. William Fulbright Papers, University of Arkansas. ${ }^{112}$ Ibid.

${ }^{113}$ Ibid.
} 
currently enjoys." Edelsberg recommended pursuing both aims simultaneously, and then potentially switching to just one course if it seemed more useful. "But the Kissinger policies will not just go away," warned Edelsberg. Therefore, he proposed that "efforts must be made to tie him more closely to the Watergate scandal. B'nai B'rith research units should not find this task beyond their scope."114

Aside from Kissinger, the memo also singled out "other insidious adversaries of the Jewish cause" that needed to be addressed - especially oil companies and pro-Arab organizations. Edelsberg regarded the energy crisis as an opportunity for oil companies to point to "Israeli greed and intransigence." Moreover, pro-Arab "propaganda" and lobbying efforts had intensified, which needed to be countered. "The Arabs have redoubled their efforts since the Yom Kippur War," wrote Edelsberg, "with the object of capitalizing on the sudden wavering of public and Administration sentiment towards Israel.” In order to neutralize those efforts, Edelsberg recommended, "The support which we have always enjoyed with the mass media must be developed ..."115

Edelsberg also recognized the importance of the legislative branch and discussed different ways of impacting certain congressional elections. As opposed to the President, legislators can serve unlimited terms. In order to determine which candidates to support, Edelsberg referenced "a meticulous and continuous survey of congressional voting records, together with both public and private statements made by individual Senators and Congressman." Using that information, a "detailed study of electoral prospects" was nearing completion, which could "show where Jewish campaign contributions can be most judiciously placed." Moreover, the memo recommended to "use all available forms of pressure, both on and

\footnotetext{
114 Ibid.
}

115 Ibid. 
off the record, to secure the desired results." One particular senator had drawn the ire of proIsrael forces, and in fact he was the senator that received the memo three years after the fact William Fulbright. "As an example of the political potentialities," wrote Edelsberg, "it can already be said that all the indications suggest that our actions in support of Governor Bumpers will result in the ousting of Mr. Fulbright from his key position in the Senate." Indeed, Fulbright lost his nomination bid a few weeks later. Stressing the importance of ethnic politics without any discussion of the American (or Israeli) national interest, Edelsberg noted that Fulbright's defeat "will represent a meaningful victory for the Jewish cause in the struggle against skeptical elements in the State Department and elsewhere."116

In order to continue to influence American policy at its highest levels of operation required a working relationship with individuals committed to advancing a position in line with certain pro-Israel lobbying forces. Edlesberg pointed to Scoop Jackson and Defense Secretary James Schlesinger. Jackson's support for Israel had "endeared him to all Jews", and as the 1976 presidential election loomed in the future, Edelsberg argued that "it is necessary to redouble efforts in his support." Schlesinger was important because he was a link to the Pentagon. But aside from Schlesinger and Jackson, Edelsberg feared that sentiment was turning against Israel. Therefore, he noted that "we must seek other means of access to the Joint Chiefs of Staff." To better achieve such goals, Edelsberg suggested "an attempt to establish closer coordination with other Jewish organizations in the United States."

Whether or not B'nai B'rith or other pro-Israel organizations actually enacted a deliberate attempt to discredit Kissinger is hard to say. But shortly after this document was created,

\footnotetext{
${ }^{116}$ Ibid.

${ }^{117}$ Ibid.
} 
Kissinger had to take on a firestorm in the press about his relationship to Watergate and illegal activities.

Perhaps coincidentally, perhaps not, Kissinger had to deal with press stories about his potential involvement in Watergate as he was negotiating Sinai I in January 1974. During his shuttle negotiations between Egypt and Israel, Kissinger was asked about a recent story that claimed he had ordered unauthorized phone taps on Defense Secretary Melvin Laird. Kissinger responded, "I have only read the Reuters summary. I think it is a vicious, malicious, outrageous lie. I think anonymous sources who put out lies of this nature should come out from behind their cover." ${ }^{118}$ The next day, 14 January 1974, Kissinger sent another cable to Scowcroft asking his White House colleagues for advice on how to handle the recent flurry of press reports that sought to tie Kissinger to Watergate. He emphasized "the difficulties imposed upon me by having to put time on this ridiculous matter in the midst of efforts to bring about a Middle East settlement."119 Nevertheless, Kissinger managed to bring Egypt and Israel together for a disengagement agreement.

A similar effort to connect Kissinger to the illegalities of the White House happened while he was shuttling between Syria and Israel. On 12 May the Boston Globe reported that Kissinger may have committed perjury when asked by the Senate Foreign Relations Committee about his role in wiretaps. A 17 May New York Times piece accused Kissinger of "prolonging his shuttle diplomacy in order to avoid the even more complicated and poisonous controversies of Washington." ${ }^{120}$ According to Kissinger, "by May 22 this had become a general theme taken up

\footnotetext{
${ }^{118}$ Diplomatic Cable, from Eagleburger HAKTO 12 to General Scowcroft, 13 January 1974, RNPL, NSCF, Henry A. Kissinger Office Files, HAK Trip Files, Box 43, Folder - HAK Trip Europe \& Mid East Jan 10-20, 1974, TOHAK 1-65 [1 of 2].

${ }^{119}$ Diplomatic Cable, HAKTO 015 to Scowcroft, 14 January 1974, RNPL, NSCF, Henry A. Kissinger Office Files, HAK Trip Files, Box 43, Folder - HAK Trip Europe \& Mid East Jan 10-20, 1974, TOHAK 1-65 [2 of 2].

${ }^{120}$ Kissinger, p. 1091.
} 
by both the CBS and NBC television correspondents of my shuttle." ${ }^{\prime 21}$ In his memoirs, Kissinger referenced an article from "the left-wing magazine New Times" that claimed, "The honeymoon is over for Henry Kissinger. There are signs that the media is [sic] going after him for the first time ..."122 To counteract the stories, the White House press office acknowledged that Nixon had specifically asked Kissinger to stay in the Middle East until he reached an agreement. But in trying to protect Kissinger, the plan actually backfired as it undermined one of Kissinger's negotiating tactics - threatening to pack up and leave. Kissinger expressed his dissatisfaction in an urgent cable to Scowcroft. ${ }^{123}$

Kissinger managed to navigate both domestic and regional problems as Syria and Israel agreed to a disengagement of forces on 31 May. Israel committed itself to withdraw from all the territory taken in the 1973 war, along with Quneitra, capital of the Golan, in return for prisoners of war. Similar to Sinai I, the Golan Heights was divided into Israeli and Syrian zones with a substantially reduced military presence, separated by a UN presence in-between; the main difference was that each side had two separate zones, rather than one, on each side of the buffer zone. $^{124}$

Soon after the agreement, Kissinger buckled under the pressure of persistent questions about his role in wiretapping, and his credibility more generally. During a 6 June press conference, just short of a week after his successful Middle East shuttle, Kissinger was asked several questions about his role in Watergate. One journalist asked if he had retained counsel for a possible perjury indictment. Kissinger responded that he had not, and that he would "answer no further questions on the topic." By evading questions Kissinger encouraged more attacks, which

\footnotetext{
${ }^{121}$ Ibid.

${ }^{122}$ Ibid., p. 1115.

${ }^{123}$ Ibid., p. 1092.

${ }^{124}$ Spiegel, p. 280.
} 
were soon to follow. "The June 6 press conference opened the floodgates," said Kissinger. "There was next to no coverage of the foreign policy questions and answers." ${ }^{25}$ Over the next several days, leading newspapers, especially the New York Times and Washington Post, along with leading news magazines, like Time and Newsweek, published stories that tried to connect Kissinger to Watergate. ${ }^{126}$ By 11 June, "the leading news media of the United States ... had taken the position that serious new evidence had raised suspicion of perjury requiring a new investigation." Clearly overcome with frustration, Kissinger fired back during his press conference in Salzburg - "I do not believe that it is possible to conduct the foreign policy of the United States under these circumstances when the character and credibility of the Secretary of State is at issue. And if it is not cleared up, I will resign." ${ }^{127}$ Kissinger's threat was enough to rally support for his efforts and stem the tide of criticisms, and a 6 August report from the Senate Foreign Relations Committee absolved Kissinger of any wrongdoing connected to wiretaps or perjury. After attacking the use of unnamed sources, Kissinger says his "relations with the media never fully recovered." But Kissinger maintained, "I continue to believe that anonymous accusers give journalists a power no branch of government possesses and expose public officials to much scurrilous abuse by individuals whose motives - and veracity - escape examination."128

To build on the momentum of the agreement, and while Kissinger sought to offset persistent questions about his credibility, Nixon traveled to the Middle East in early June 1974. Nixon certainly hoped to distract people's minds from the Watergate fiasco, but the trip also came on the heels of one of the most impressive moments in American diplomatic history. Henry Kissinger managed to bring Israel and Syria, two bitter enemies, together for an agreement that

\footnotetext{
${ }^{125}$ Kissinger, pp. 1116-1117.

${ }^{126}$ Ibid., p. 1117.

${ }^{127}$ Ibid., p. 1120.

${ }^{128}$ Ibid., p. 1122.
} 
remains one of the strongest political agreements to date between the two states. Importantly, the step with Syria was the second in an effort to build momentum toward implementation of UN Resolution 242 as part of a comprehensive peace based on bilateral agreements. And while Nixon was looking for anything to save his beleaguered Presidency, he also genuinely wanted to advance the peace process. By visiting the Middle East he sought to capitalize on the momentum created by the recent agreement while diverting attention away from his domestic troubles. And as a briefing paper for Kissinger noted, "perhaps the main purpose of the trip was to strengthen our bilateral relations with the nations of the Middle East." 129

Prior to his trip, Kissinger sent Nixon a memorandum about the status of Middle East negotiations and certain points to make with Israeli officials. The memo stressed the importance of maintaining momentum, arguing that the US and Israel needed to "develop a common strategy for keeping the present diplomatic process going." 130 Kissinger noted that some time needed to pass in order for the Syrian disengagement to take hold. "But we cannot lose momentum altogether," he said. Kissinger recognized that Israeli officials would likely press Nixon about commitments regarding the Golan Heights, Jerusalem, final borders, or Palestinian refugees, and he advised the President to resist making such commitments. Instead, he recommended that Nixon mention that the final peace needed to be "worked out in direct negotiations. The US has produced the framework for those negotiations." 131

Nixon, too, was concerned about the Israeli position. In his memoirs, Nixon recalled a 5 June meeting with leaders of the American Jewish community that left him "disturbed by what I

\footnotetext{
${ }^{129}$ Talking Points, Secretary Kissinger's Briefing on the President's Middle East Trip, 20 June 1974, RNPL, NSCF, Harold H. Saunders Files, Middle East Negotiations Files, Box 1189, Folder - President's Middle East Trip, June 10-19, 1974, File \#2 (2 of 4).

${ }^{130}$ Memorandum for The President from Henry A. Kissinger, "Your Talks in Israel," June 1974, RNPL, NSCF, Henry A. Kissinger Office Files, Country Files - Middle East, Box 136, Folder - Dinitz January 1 - July 1, 1974 (2 of 2) [1 of 2].

${ }^{131}$ Ibid.
} 
considered to be their shortsighted outlook." According to Nixon, "I pointed out that hardware alone to Israel was a policy that made sense maybe five years ago but did not make sense today," and that "I made it very clear there is going to be no blank check in our conversations with the Israelis." Furthermore, Nixon argued that "the only long-term hope lies in reaching some kind of settlement now while they can operate from a position of strength."132

The issue of Palestinian refugees continued to present challenges. Kissinger noted that Israel would have a very difficult time dealing with Palestinian organizations because of ongoing terrorist attacks. Therefore, the US sought "to isolate the radical Palestinians by providing some focus for moderate Palestinian support. This is why some negotiation with Jordan seems important." ${ }^{\prime 33}$ But as Paul Chamberlin has persuasively argued, the PLO was moderating its behavior vis-à-vis other Palestinian organizations vying for power and influence; nevertheless, neither Kissinger nor the Israelis had any interest in including a Palestinian political organization in peace discussions, and instead pressed the Jordanian option with Israeli officials. ${ }^{134}$ But the Jordanian option would not come to pass, and the inability to resolve the Palestinian refugee problem doomed the peace process.

Nixon received a warm welcome wherever he traveled in the Middle East, especially in Cairo and Damascus. In Egypt, more than a million people filled the streets of Cairo to see the American president, and on 16 June, Nixon and Asad agreed to resume normal diplomatic relations between the US and Syria. For Nixon, the "strengthening of our bilateral relations" included "educational and cultural exchanges" and an invitation to Asad to visit the United States, which he accepted. Like Sadat, Asad was more interested in working with the United

\footnotetext{
132 Richard Nixon, The Memoirs of Richard Nixon (New York: Grosset \& Dunlap, 1978), pp. 1007-1008. 133 Ibid.

${ }^{134}$ Paul Chamberlin, The Global Offensive: The United States, the Palestine Liberation Organization, and the making of the Post-Cold War Order (Oxford: Oxford University Press, 2012).
} 
States than with Israel. "The Syrian Arab Republic," said Asad, "declares its readiness to pursue its sincere and constructive cooperation with the Government of the United States of American for laying down the firm basis for a just and lasting peace in the Middle East region."135

The dramatic transition to normal diplomatic relations was perhaps best expressed by Asad's son, Bashir al-Asad, who succeeded his father as President in 2000, and remains President despite an ongoing revolution. In conversation with his dad in June 1974, the younger Asad said, "This Nixon who is coming, isn't he the one who you have said is the foreign devil and the tool of the Jews? How come you are inviting him here?"136

Nixon proved unable the lay the groundwork for an Israel-Jordan agreement. According to historian Richard Thornton, the American effort to pursue an agreement with Jordan "fell upon deaf ears in Israel." ${ }^{137}$ The main problem, according to Thornton, was the weak leadership of the new Rabin cabinet. ${ }^{138}$ When Rabin assumed the Prime Minister position in early June, his cabinet reflected the deep divide between the right and left as the moderate Yigal Allon served as Foreign Minister while the hawkish Shimon Peres served as Defense Minister; Rabin oftentimes filled something of a middle position between Allon and Peres. Rabin did not have the authority to follow a course of his choosing that may have included more of an effort to engage Jordan. Interestingly, Peres explained to Senator Javits during the latter's trip to Israel in July that he was "puzzled" by the U.S. effort to bring Israel and Jordan together for an agreement, noting that he and other Israeli leaders were planning for the next agreement to be a second step with Egypt. ${ }^{139}$

\footnotetext{
${ }^{135}$ The American Presidency Project, "Remarks About Resumption of Diplomatic Relations Between the United States and Syria," 16 June 1974, http://www.presidency.ucsb.edu/ws/?pid=4256, accessed 7 May 2015.

${ }^{136}$ Memorandum of Conversation, Nixon and Bipartisan Leadership, 20 June 1974, RNPL, NSCF, Presidential/HAK MemCons, Box 1029, Folder - MEMCON'S HAK and Presidential, 1 June 1974 --- [Aug.8, 1974] [2 of 3].

${ }^{137}$ Thornton, p. 290.

${ }^{138}$ Ibid.

${ }^{139}$ Diplomatic Cable, American Embassy in Tel Aviv to Kissinger, 6 July 1974, RNPL, NSCF, Harold H. Saunders Files, Middle East Negotiations Files, Box 1185, Folder - M.E. Peace Negotiations - July 1-13, 1974 [2 of 2].
} 
Jordan did not seem particularly interested in moving forward with peace negotiations, either. According to a journalist who cited "reliable Israeli sources," Dayan met with King Hussein near the end of May and proposed an agreement based on Jordanian civilian control of the West Bank and an Israeli military presence. ${ }^{140}$ But Hussein refused the offer, perhaps uncomfortable with the substantially increased presence of a Palestinian people determined to obtain a nation-state inside Jordan's borders, especially after Black September.

But the Administration continued to press the Jordanian option. Nixon mentioned that Jordan came last because the three most difficult issues - the West Bank, Jerusalem, and Palestinian refugees - all involved Jordan. ${ }^{141}$ But the Israeli political situation promised to be a complication, and in fact Israeli officials had expressed a desire "to wait two or three years." But Nixon said bluntly, "We can't wait. It won't be in the next 2-3 weeks, but we must move."142 The Administration planned to use economic incentives to spur bilateral peace agreements between Israel and Egypt and Israel and Syria, which "is why we are setting up cooperative commissions for both of them. That is why we have asked for aid for them - we want to give them a stake in continuing to work with us." ${ }^{, 143}$ Kissinger sent a cable on 13 July to the American ambassadors in the Middle East that stressed the importance of a Jordanian agreement, and the willingness of the Administration to pursue a peaceful resolution to the conflict. "As for U.S. policy on further Israeli withdrawals from occupied territories," said Kissinger, "we continue to support and work for comprehensive Middle East settlement as envisaged in UNSC Reses 242 and 338 and have made clear we view disengagement agreements so far achieved as only first steps toward final just and durable peace." Kissinger also added that the Administration sought a

\footnotetext{
${ }^{140}$ Diplomatic Cable, American Embassy in Tel Aviv to Kissinger, 29 July 1974, RNPL, NSCF, Harold H. Saunders Files, Middle East Negotiations Files, Box 1185, Folder - M.E. Peace Negotiations - July 14-31, 1974 [1 of 2].

${ }^{141}$ Ibid.

${ }^{142}$ Ibid.

${ }^{143}$ Ibid.
} 
Jordanian-Israeli agreement based on "our recognition that any peace settlement must take into account legitimate interests of Palestinian people."144

To the Administration's liking, the Israeli cabinet voted in favor of pursuing negotiations with Jordan on 21 July. The government of Israel released a "statement reportedly drafted by PM Rabin himself" that declared, "The government will work towards negotiations for a peace agreement with Jordan." 145 The cabinet voted down a minority proposal that "was intended to express more positive attitude to issue of possible negotiations with Palestinian organizations". However, opposition to the proposal, "led by Rabin, wanted to make it crystal clear that Israel would not conduct separate negotiations with Palestinian organizations. GOI position however does not bar inclusion of Palestinians in Jordanian delegation to Geneva conference or other forum." ${ }^{146}$ Foreign Minister Yigal Allon visited Washington in late July to talk with Kissinger the next step, which included the possibility of an agreement with Jordan.

But Nixon never had a chance to follow through on his peace-making efforts as Watergate finally forced the President's resignation on 9 August. The transition to the unelected Ford included keeping Kissinger as a holdover for both his duties - Secretary of State and National Security Adviser. It would be up to the new Ford Administration to pursue a comprehensive peace.

\footnotetext{
${ }^{144}$ Diplomatic Cable, Kissinger to American Embassies in Jidda, Amman, Beirut, Cairo, Damascus, and Tel Aviv, and the American Consul in Jerusalem, 13 July 1974, RNPL, NSCF, Harold H. Saunders Files, Middle East Negotiations Files, Box 1185, Folder - M.E. Peace Negotiations - July 1-13, 1974 [1 of 2].

${ }^{145}$ Diplomatic Cable, American Embassy in Tel Aviv to Kissinger, 22 July 1974, RNPL, NSCF, Presidential/HAK MemCons, Box 1029, Folder - MEMCON'S HAK and Presidential, 1 June 1974 --- [Aug.8, 1974] [1 of 3]. ${ }^{146}$ Ibid.
} 


\section{Conclusion}

The American plan advanced by Nixon and Kissinger was successful in achieving the two primary goals of step-by-step diplomacy. The U.S. did in fact develop much better relations with Arab states, marked especially by the end of the oil embargo and the resumption of diplomatic relations with Egypt and Syria. Additionally, step-by-step diplomacy provided a negotiating framework for Israel to pursue lasting bilateral peace arrangements as part of a comprehensive peace program.

But domestic challenges complicated the American effort during the Nixon Administration. Documentation shows that the American Jewish community and powerful international organizations like B'nai B'rith actively sought to influence U.S. policy. On numerous occasions, American officials expressed concern that the American Jewish community was more intransigent than Israel. Nixon's position steadily deteriorated throughout the period of step-by-step diplomacy, to the point that Golda Meir, according to Kissinger, brushed off Nixon's threat to withhold aid in early May. When he resigned in August, the White House was only a shell of what it had been in 1968 or 1972 . The unelected Gerald Ford - probably the weakest President in American history - was positioned to pursue one of the most ambitious diplomatic schemes during the Cold War. One can only wonder what would have happened with the peace process if Nixon had not been dragged down by Watergate.

Richard Nixon resigned the Presidency on August 9, 1974. He was replaced by Gerald Ford, the longtime Republican congressman from Michigan. Ford had always wanted to become Speaker of the House, but historical events pushed him in a different direction - first to Vice President, and ultimately to President. Known to be a supporter of Israel while serving in the House, Ford soon discovered that foreign policy concerns looked much different from inside the 
White House, than from inside the Capitol. Ironically, perhaps, the experienced legislator's

Presidency witnessed ongoing conflict with Congress, especially in the realm of foreign policy. 


\section{Chapter 5: \\ Walking Out of Step: Ford, Kissinger, and Step-By-Step Diplomacy}

"What they are doing to the Sinai agreement is unbelievable. It is the greatest achievement since the opening to China and all that is happening is they are pissing all over it." [Henry Kissinger to Gerald Ford, speaking about congressional criticisms of the Sinai II disengagement agreement, September 26, 1975. ${ }^{1}$ ]

Sour relations between Congress and the White House over American foreign policy came to a climax in 1975. Coming out of World War II, Congress had granted unprecedented powers to the 'Imperial Presidency' to fight the Cold War. But after the disastrous war in Vietnam, a number of serious crimes (Watergate) in which the President was trying to add to his already significant power, and the resounding Democratic victories in the 1974 mid-term elections, Congress felt obligated to contest the White House's growing power.

This challenge to presidential power was especially evident in matters relating to foreign policy. ${ }^{2}$ For example, the War Powers Resolution of 1973 had legally prevented the President from committing United States armed forces to an armed conflict for more than 60 days without congressional consent; Congress refused to allocate aid to South Vietnam against President Ford's recommendation; after Turkey's invasion of Cyprus, the two branches butted heads over aid shipments to Turkey; the White House offered financial and military support to anti-leftist rebels in the Angolan civil war, while Congress opposed becoming involved in another foreign conflict; Secretary of State and National Security Advisor Henry Kissinger's Cold War détente with the Soviet Union was being attacked by members of both parties in Congress, with efforts such as the Jackson-Vanik Amendment to the Trade Act of 1974 that aimed to punish the Soviet

\footnotetext{
${ }^{1}$ Memorandum of Conversation, President Gerald Ford, Henry Kissinger, and Brent Scowcroft, September 26, 1975, Memcons, Box 15, September 26, 1975 - Ford, Kissinger, Gerald R. Ford Library [hereafter, GRFL].

${ }^{2}$ A few historical works that perhaps best discuss the fight between the executive and legislative branches for control of foreign policy are Robert D. Schulzinger, Henry Kissinger: Doctor of Diplomacy (New York: Columbia University Press, 1989), Yanek Mieczkowski, Gerald Ford and the Challenges of the 1970s (Lexington: The University Press of Kentucky, 2005), and George Lenczowski, American Presidents and the Middle East (Durham: Duke University Press, 1990).
} 
Union for human rights violations; and congressional committees chaired by Representative Otis Pike (D-NY) and Senator Frank Church (D-ID) sought to curb the power of the CIA, an organization typically at the disposal of the White House. As Robert Schulzinger explains in Henry Kissinger: Doctor of Diplomacy, the chasm between the White House and Capitol Hill was wide. "When Kissinger requested \$270 million to aid Cambodia, Congressman Donald Fraser (D. - Minn.) denounced the 'bankrupt policy ... of the Department of State which will lead nowhere, which will cause not only an expenditure of money for no good end, but will lead to the increased loss of life."”3 According to Ford in a 2003 interview, "There was, I thought, an unfortunate encroachment by the Congress on foreign power action by the United States ... Congress was trying to claw its way into the foreign policy arena, and that inevitably was a potential encroachment on presidential power." ${ }^{4}$

The combative relationship between the two branches can perhaps be seen most clearly in Middle East relations, and more specifically, the White House's negotiation of the Sinai II disengagement agreement between Israel and Egypt in 1975. Significantly, few authors have examined Ford's Middle East policy in the context of contentious Executive-Congressional relations. As mentioned in Chapter 4, Henry Kissinger stated in his memoirs that of all the foreign policy concerns, Watergate and Vietnam affected U.S.-Middle East relations the least. But again, that position is hard to reconcile with the documentary evidence. After Arab-Israeli discussions stalled in March, President Ford declared a 'reassessment' of United States Middle East policy that included a freezing of foreign aid to all countries in the region. Reassessment amounted to being a power play by the Ford White House designed to soften the Israeli negotiating position by threatening to withhold aid. But in the course of reassessing policy,

\footnotetext{
${ }^{3}$ Schulzinger, 191.

${ }^{4}$ Ford quoted in Mieczkowski, 281. Mieczkowski cites the 21 August 2003 interview with Ford in his notes (410).
} 
President Ford received a letter from 76 U.S. senators that, first, stipulated the belief that Congress should play a more active role in foreign policy and, second, that shipments of aid to Israel should resume. [Also discussed in Chapter 6]

The letter demonstrated the absence of Congressional support for the White House and undercut Ford's foreign policy maneuvers in the Middle East. When Israel and Egypt finally completed an agreement in late August 1975, in order to make the agreement acceptable to both sides and keep the peace process stepping forward, the White House had to use secret agreements, aid packages, and the promise of United States civilian personnel to man an early warning station in the Sinai Peninsula. The situation had obvious parallels to Vietnam. Therefore, Congress spent considerable time and effort debating the agreement and recommending changes, which drew the ire of Henry Kissinger, who believed Congress was trying to soil a landmark agreement.

Despite its importance, very little scholarship has been written about the Sinai II disengagement agreement. Aside from two books by journalists immediately after the agreement - Matti Golan, The Secret Conversations of Henry Kissinger and Edward R. F. Sheehan, The Arabs, Israelis, and Kissinger - there has yet to be an extensive treatment of the agreement put into historical perspective. ${ }^{5}$ Surveys of U.S.-Middle East relations, like Michael Oren's Power, Faith, and Fantasy, similarly overlook the importance of Sinai II. ${ }^{6}$ However, a number of

\footnotetext{
${ }^{5}$ Matti Golan, The Secret Conversations of Henry Kissinger (New York: Quadrangle, 1976) and Edward R. F. Sheehan, The Arabs, Israelis, and Kissinger (New York: Reader's Digest Press, 1976).

${ }^{6}$ Michael B. Oren, Power, Faith, and Fantasy: America in the Middle East, 1776 to the Present (New York: W.W. Norton \& Co., 2007). See also, Peter Hahn, Crisis and Crossfire: The United States and the Middle East since 1945 (Washington D.C.: Potomac Books, 2005); Douglas Little, American Orientalism: The United States and the Middle East since 1945 (Chapel Hill: University of North Carolina, 2002); Odd Arne Westad, The Global Cold War: Third World Interventions and the Making of Our Times, (Cambridge: Cambridge University Press, 2007); and Seth P. Tillman, The United States in the Middle East: Interests and Obstacles, (Bloomington: Indiana University Press, 1982).
} 
authors have dedicated at least a chapter within a larger work to the agreement. ${ }^{7}$ William Quandt, former National Security Council member and active participant in both the Camp David Accords and the Egyptian-Israeli Peace Treaty, discusses Sinai II in a chapter of Peace Process that spans the course of Kissinger's step-by-step diplomacy from 1974-76. ${ }^{8}$ But Quandt, like other scholars, understates the Ford administration's efforts to secure a comprehensive peace and the confrontational nature between the legislative and executive branches. Perhaps the most useful, recent work that incorporates newly released documents into an analysis of Sinai II is Salim Yaqub's chapter in Nixon in the World: American Foreign Relations, 1969-1977.9 Yaqub argues that Kissinger's pro-Israeli slant was the decisive factor in the U.S. government's willingness to allow Israel to keep chunks of territory it had pledged to return to Arab hands. This seems like a reasonable argument given Kissinger's Jewish background and the "special relationship" between the U.S. and Israel. But as copious documentation shows, both Ford and Kissinger were outraged by Israeli diplomatic tactics and the Ford White House made genuine efforts to bring about a comprehensive peace settlement that would have been in the spirit of UN Resolutions 242 and 338. Yet such an agreement was perceived by Israel to be against its

\footnotetext{
${ }^{7}$ See also, William B. Quandt, Decade of Decisions: American Policy Toward the Arab-Israeli Conflict, 1967-76 (Berkeley: University of California Press, 1977); Ishaq I. Ghanayem and Alden H. Voth, The Kissinger Legacy: American-Middle East Policy (New York: Praeger Publishers, 1984); Lawrence I. Conrad, ed., The Formation and Perception of the Modern Arab World: Studies by Marwan R. Buheiry (Princeton: The Darwin Press, Inc., 1989), 394-99, 467-479; Burton I. Kaufman, The Arab Middle East and the United States: Inter-Arab Rivalry and Superpower Diplomacy (New York: Twayne Publishers, 1996); The Middle East: U.S. Policy, Israel, Oil and the Arabs, second edition (Washington D.C.: Congressional Quarterly, Inc., 1975), 9-21; and James A. Bill, George Ball: Behind the Scenes in U.S. Foreign Policy (New Haven: Yale University Press, 1997), 176-200.

${ }^{8}$ William B. Quandt, Peace Process: American Diplomacy and the Arab-Israeli Conflict since 1967, third edition, (Washington D.C.: Brookings Institution Press, 2005).

${ }^{9}$ Salim Yaqub, "The Weight of Conquest: Henry Kissinger and the Arab-Israeli Conflict," in Nixon in the World: American Foreign Relations, 1969-1977 ed. Fredrik Logevall and Andrew Preston (New York: Oxford University Press, 2008), 227-248.
} 
interests. Henry Kissinger's papers relating to the agreement, now mostly-declassified and residing in the Gerald Ford Presidential Library, say as much. ${ }^{10}$

By 1975, the fractured relationship between the White House and Congress resulted in the two branches walking out of step while trying to implement Kissinger's step-by-step diplomacy. The Administration ultimately signed off on the Sinai II agreement, which included a multi-year, multi-billion dollar aid plan for Israel, along with a stated commitment to not pursue steps in the peace process apart from Israel. In doing so, the Ford administration cemented the special relationship between the United States and Israel. But that development cannot be understood apart from the efforts of the U.S. Congress and pro-Israel lobbying groups, a theme that is also explored in Chapter 6. Importantly, none of the above-mentioned scholarly works systematically address the crucial issue of executive-congressional relations.

The domestic political situation, and especially the animosity between Congress and the White House, created conditions that contributed to the undoing of the U.S.-led peace process. The Administration sincerely aimed to use a series of agreements, Kissinger's 'step-by-step diplomacy,' to bring about a full peace program for the Arab-Israeli conflict. Surprisingly perhaps, given the toxic nature of relations between the two branches in 1975, the U.S. Senate seen through the perspectives of George McGovern and Charles Percy (the two ranking members of the Senate Foreign Relations Committee) - had goals nearly identical with the White House. In the end, however, the two branches of the same government could not coordinate their visions. Rather than working in harmony, the two branches worked in opposition. In effect, the power struggle set in motion by Vietnam, Watergate, and a struggling economy, along with strong support for the Israeli position in the U.S. Congress, actually neutralized Washington's ability to

\footnotetext{
${ }^{10}$ Most of Kissinger's papers at the Ford Library were opened in 2003-04. The previous inaccessibility of these papers is one reason why the importance of Sinai II has remained outside of scholarly consciousness.
} 
act coherently and project its power on an international stage. The result was a stillborn comprehensive peace plan for the Arab-Israeli conflict.

When Gerald Ford inherited the presidency from Richard Nixon in August 1974, he inherited a messy situation in the Middle East. Israel had been attacked by Egypt and Syria on Yom Kippur in October 1973, and the aftermath of the conflict carried over into Ford's presidency. The Arab states had initiated hostilities to remind the Jewish state about unsettled issues relating to the ongoing Arab-Israeli peace process, particularly Palestinian refugees and redrawn borders. The surprise attack had sent Israeli forces reeling, but thanks to an American resupply of munitions, Israel was able to mount a counterattack and gain control of the war. In response to the American airlift of aid, the Organization of Petroleum Exporting Countries (OPEC) placed an embargo on oil shipments to the United States. The ensuing energy crisis forced the United States government to play a more direct role in brokering a peace agreement, which it had intentionally refrained from doing in previous years.

Following the conflict, Henry Kissinger, Secretary of State and National Security Advisor for President Nixon, implemented a diplomatic procedure called 'step-by-step diplomacy' that sought to eventually lead the combatants to a final peace agreement that addressed Palestinian grievances and border disputes. Kissinger first developed step-by-step diplomacy to work out agreements with the Chinese, Russians and Vietnamese, all connected in some way to the Vietnam War. ${ }^{11}$ Having worked successfully in Southeast Asia, Kissinger applied a similar method to Middle East affairs. The piecemeal approach, according to William B. Quandt, embodied a system. In the words of Quandt, "It was important to create the proper balance of incentives first; then to reach limited results at an early stage without making

\footnotetext{
${ }^{11}$ Peace Process, 18.
} 
commitments to the final goal; eventually, when a mutuality of interests had emerged, more substantial areas of agreement would be possible."12 In other words, Kissinger wished to make small diplomatic gains and use them as building blocks toward a final peace settlement. First, he would tackle simple problems that had easy solutions, and then move on to discussions about more pressing matters, like final borders and the Palestinian refugees. In the meantime, Israel would have time to consider the direction of its policy with respect to the occupied territories, the Soviet Union would be kept on the diplomatic sidelines, and an atmosphere conducive to peace would be created in the Middle East.

Kissinger began his Middle East version of step-by-step diplomacy during the cessation of hostilities following the 1973 Arab-Israeli war. After two ceasefires brought the fighting to a pause, Kissinger helped negotiate the peaceful release of the Egyptian Third Army Corps, which had been encircled by Israeli forces. The accord, Kilometer 101, was signed November 11, 1973, and was the first meeting between Kissinger and Egyptian President Anwar Sadat. Following the small diplomatic success, Kissinger used 'shuttle diplomacy' to negotiate a disengagement agreement between Israel and Egypt, Sinai I, on January 18, 1974. ${ }^{13}$ Step-by-step diplomacy produced another interim agreement, this time between Israel and Syria over the Golan Heights, on May 31, 1974. But step-by-step diplomacy became increasingly ineffective after the IsraeliSyrian agreement. Having disengaged belligerents in the Sinai Peninsula and Golan Heights, the peace process demanded some type of Israeli-Jordanian agreement involving the West Bank.

\footnotetext{
${ }^{12}$ Decade of Decisions, 212.

${ }^{13}$ Kissinger would 'shuttle' between Middle East capitals to negotiate with heads of state and negotiating teams, serving as an intermediary between two parties. He used shuttle diplomacy to negotiate a ceasefire to end the Yom Kippur War, and then for all three disengagement agreements. This feature of his personal style of diplomacy is often mentioned in connection with step-by-step diplomacy, but the two are separate ideas. The former involves his movement between cities on behalf of other parties, while the latter refers to his diplomatic method for resolving the Arab-Israeli conflict.
} 
That, however, meant introducing the Palestinian question to the peace process, which would make negotiations even more fragile.

An interim agreement between Israel and Jordan never came to fruition. On October 28, 1974, the Arab League summit assembled in Rabat, Morocco and unanimously endorsed the Palestinian Liberation Organization (PLO) as the sole representative of the Palestinians. ${ }^{14}$ The Arab League's action was a deliberate attack on step-by-step diplomacy; Arab leaders wanted an immediate, comprehensive agreement rather than the more methodical, piecemeal approach. In other words, the patience afforded Kissinger by Arab leaders immediately after the 1973 war roughly a year earlier (discussed in Chapter 4) had grown thin. If the PLO represented the Palestinians, then Jordan would have no authority to negotiate any settlement involving the West Bank.

Foreign policy was not President Ford's area of expertise. He had supported Nixon's policies in Southeast Asia and was known to be a good friend of Israel. ${ }^{15}$ Otherwise, Ford's position on foreign policy matters was unknown. Lacking experience, the President trusted his Secretary of State and National Security Adviser (Kissinger was both at this time) to take charge of U.S. foreign policy, especially in the Middle East.

Refusing to deal with the PLO was fine with Kissinger. He felt the organization was too radical and potentially harmful to his diplomatic process. Step-by-step diplomacy fed slowly off victories, but starved quickly with defeats. It was not in America's best interest to begin negotiations with a loose-cannon organization. After all, the PLO was more concerned with

\footnotetext{
${ }^{14}$ Peace Process, 159. The League, comprised of the leading Arab states, likely endorsed the PLO to undermine Kissinger's plans to negotiate with Jordan. In particular, Syria and Saudi Arabia put forward staunch support of the PLO. The Arab states never approved of any state separately negotiating a peace with Israel. In fact, Sadat's signature on the Camp David Peace Accords ultimately sealed the fate of his own assassination in 1981, at the hands of Islamic Jihad.

${ }^{15}$ Peace Process, 156.
} 
disrupting diplomacy between Israel and moderate Arab states than in negotiating an agreement with Israel, which the PLO would not recognize as a legitimate state anyway. A simple misunderstanding, if not handled properly, could undermine the entire process. Additionally, the PLO was widely known to use terrorism for political means. For that reason and others, the United States did not recognize the political legitimacy of the PLO, which made negotiations practically impossible. ${ }^{16}$

But stagnation of the peace process was also bad, a point made clear by Anwar Sadat in October 1973 when he chose a surprise attack on Israel to restart the stalled peace process. With West Bank negotiations on hold, Kissinger needed another partner to keep 'stepping' toward peace. "To salvage his policy and reputation," Quandt writes, "he needed another success."17 Even before the meeting in Rabat, Kissinger had received word of a possible second disengagement agreement developing between Israel and Egypt. The Egyptians wanted territory in the Sinai. They specifically desired the strategically important Mitla and Giddi passes, along with control over the Abu Rudeis and Ras Sudr oil fields; the fields provided Israel with fifty percent of its total oil needs. ${ }^{18}$ But this time Israel and Egypt were far apart. Israel refused to accept any agreement that did not include a formal end to belligerency, nor one that included a withdrawal from the passes or oil fields. ${ }^{19}$ Otherwise, Israel claimed, it would be unable to defend itself if attacked again. However Kissinger and Ford were taken by surprise when Israel insisted on nonbelligerency (discussed in Chapter 6). The purpose of step-by-step diplomacy had always been to use small diplomatic gains to eventually construct a full peace settlement based

\footnotetext{
${ }^{16}$ Yasser Arafat, leader of the PLO, participated in several terrorist raids against Israel while a member of Fatah. Israel cited those particular raids, along with several other grievances, as its justification for war in June 1967. In addition, the United States steadfastly refused to recognize the PLO until the organization publicly acknowledged Israel's right to exist. This step was finally taken in the fall of 1988, when Arafat did indeed recognize the state of Israel. His statement was eventually followed by U.S. diplomatic recognition of the PLO.

${ }^{17}$ Decade of Decisions, 257-58.

${ }^{18}$ Peace Process, 160.

${ }^{19}$ Peace Process, 160.
} 
on bilateral agreements; the Ford administration reasonably expected Israel's willingness to make concessions for peace to keep stepping forward. Thus, the stage was set for a major disappointment.

Kissinger made two separate trips to the Middle East - one in February 1975 and the next month as well - to bring the two sides closer together, all to no avail. His 'shuttle diplomacy' took him between Tel Aviv and Cairo a number of times, along with side trips to Damascus, but Kissinger managed only to get Israel to budge on the oil fields and not on the passes; the only way Israel would give up the passes was if Egypt agreed to nonbelligerency. But to officially end war with the state of Israel would have meant acceptance of the status quo, which Sadat recognized would have alienated the Arab world. So Sadat rejected the Israeli proposal, and instead of 'nonbelligerency,' Sadat offered Israeli leaders 'nonuse of force,' which in turn met with an Israeli rejection. As negotiations headed for collapse, not even a stern letter from President Ford on March 21, 1975, softened the Israeli position. ${ }^{20}$ The disengagement agreement between Israel and Egypt then quickly deteriorated and fell apart. The momentum from the previous several agreements had been ruined by the breakdown in talks, and step-by-step diplomacy had outworn its usefulness.

\section{The White House and Reassessment}

In response to the failure of step-by-step diplomacy, President Ford declared a reassessment of Middle East policy. The American agenda for peace had come to a standstill with the breakdown of talks. The Ford administration had to make a choice: either resurrect stepby-step diplomacy and seek a separate Israeli-Egyptian agreement, or pursue a comprehensive settlement that went against the wishes of Israel.

\footnotetext{
${ }^{20}$ Peace Process, 163.
} 
While traveling back to Washington from Israel, Kissinger's Middle East negotiating team composed an "all-purpose" talking paper detailing American policy to help focus the impending reassessment. ${ }^{21}$ The paper stated two crucial factors and proceeded to outline the American strategy following the October War. The first was that "the 1973 war brought a breakdown of the no-war, no-peace stalemate and led to new perceptions and new power relations in the area." 22 The Arab states had demonstrated their collective military might, and even though they failed to defeat Israel militarily, "Israel recognized it had become overconfident and could not stand pat on the status quo." 23 The second factor "was President Sadat, who, starting in 1970, shifted Egypt from a radical policy of reliance on the Soviets and hostility toward the United States and conservative Arab regimes to a post-October 1973 strategy of reliance on the U.S. to help him achieve his political and economic objectives." 24

The changing situation forced Washington to forge a new strategy - Kissinger's step-bystep diplomacy. The plan, according to the talking paper, had been "to break the Arab-Israeli problem down to manageable elements and deal with them on a step-by-step basis." According to Kissinger, "The success of the strategy required each party to put aside demands that the other commit itself in advance to final positions on such fundamental issues as final borders, Palestinian rights, and commitments to end belligerency and establish peace. The hope was to move ahead at a measured pace which would induce a gradual change in basic Arab-Israeli hostility."25

\footnotetext{
${ }^{21}$ Gompert to Scowcroft, "Talking Points on the Middle East," March 26, 1975, Presidential Country Files for Middle East and South Asia, 1974-1977, Box 1, General (6), GRFL.

${ }^{22}$ Ibid.

${ }^{23}$ Ibid.

${ }^{24}$ Ibid.

${ }^{25}$ Ibid.
} 
Such a plan desired to bring about three effects. First, "to persuade the Arabs that their best means to a settlement lay in working through and improving relations with the United States, thus creating an Arab vested interest in avoiding confrontation on oil and other matters with the United States." Second, "to neutralize the Soviet opposition to our pre-dominant role in the peacemaking process." And third, "to fend off European and Japanese pressures through us on Israel to move on several fronts simultaneously and more rapidly than Israel's political process could handle." ${ }^{, 6}$ In short, the ultimate goal of the U.S. strategy was "to maintain control of the negotiations, insulate Israel against outside pressures [to move comprehensively] and make our broader world and regional interests compatible with our interest in continued support of Israel."27 The paper concluded by stating, "Neither shuttle diplomacy nor step-by-step settlement efforts are likely to be pursued in the foreseeable future. The focus will more likely shift to multilateral diplomacy and to an overall settlement." ${ }^{, 2}$ For Kissinger, the beauty of stepby-step diplomacy was that it neutralized the Soviet Union and made Moscow appear impotent. But a comprehensive settlement, which seemed to be increasingly likely, would make Moscow look stronger and Washington look weaker.

At 8:00 a.m. on Monday morning of March 24, Ford and Kissinger met with bipartisan congressional leadership to discuss the White House's reassessment. Kissinger succinctly summarized the situation: "After the October [1973] war it was the unanimous conclusion of the world community that Israel should return to the ' 67 borders. In the face of that we cooperated in a strategy with Israel to reduce Soviet Union influence in a step-by-step process. I must

\footnotetext{
${ }^{26}$ Ibid.

${ }^{27}$ Ibid.

${ }^{28}$ Ibid.
} 
emphasize that every step was coordinated and usually at the instigation of Israel." ${ }^{29}$ Ford followed by stating the U.S. was not blaming Israel for the failure of negotiations (Ford publicly called Israel 'inflexible'), adding that, "we have to take a new look, assess the situation and any relations with all the parties. Such an assessment will start today. We undertook a massive effort, with the best intentions, support of the people and Congress. For us not to reassess the situation would not be responsible." ${ }^{30}$ Senate Democratic Majority Leader Mike Mansfield (D-MT) agreed, "You have no choice but to reassess." ${ }^{31}$ Mansfield communicated being "deeply depressed," 32 and wondered about the Israelis: "Are they expressing a death wish?" Ultimately, Mansfield expressed "grave concern at the rigidity of Israel." 33

Ford and Kissinger, despite their bland public rhetoric, were both fed up with Israeli intransigence. Ford favored a full peace settlement. He told Kissinger bluntly, "We must move comprehensively." Although Kissinger warned his president that Israel "will attack you," Ford was resolute. "I know they will hit us," said Ford, "but I kind of enjoy a fight when I know I am right." ${ }^{34}$ Kissinger too was fed up with the Israelis. The next day he lamented "the unraveling of our Middle East policy," saying "Israel has treated us as no other country could.” He blamed Israel for attempting "to blow up our Middle East strategy."35

Ford and Kissinger were worried about the American Jewish Community and its ability to influence United States policy. On the morning of March 26, Kissinger informed Ford that

\footnotetext{
${ }^{29}$ President/HAK Meeting with Bipartisan Leadership, March 24, 1975, National Security Adviser: Memoranda of Conversations, 1973-1977 [hereafter, NSA: MC], Box 10, March 24, 1975: Ford Kissinger, Bipartisan Congressional Leadership, GRFL.

${ }^{30}$ Ibid.

${ }^{31}$ Ibid.

32 Ibid.

${ }^{33}$ Ibid.

${ }^{34}$ Memorandum of Conversation, Ford, Kissinger and Scowcroft, March 26, 1975, NSA: MC, Box, 10, March 26, 1975 - Ford, Kissinger, GFRL.

${ }^{35}$ Memorandum of Conversation, Ford, Kissinger, March 27, 1975, NSA: MC, Box 10, March 27, 1975 - Ford, Kissinger, GFRL.
} 
Senator Jacob "Javits came in very threatening. If we went after Israel, he and [Senator Abraham] Ribicoff would come after me. He said our interests are identical with Israel." Kissinger blamed "three million Israelis" for "running American foreign policy. We are giving aid to Israel at a rate which would be unbelievable for any other country." 36 The next morning Kissinger told Ford, "It is not a friendly misunderstanding. If the Jewish Community comes after us, we will have to go public with the whole record." That same day, Ford and Kissinger met with Max Fisher, a Detroit oil magnate and important fundraiser of the Republican Party who had long been a leader within the American Jewish Community. According to Fisher, "The reassessment raises too many fears. This weakens the hand of what you are doing in diplomacy." But Ford defended his position: "Henry and I have spent more time on this than on any other foreign policy issue. We put my credibility on the line and it was a hell of a disappointment." He went on to say that "nothing has hit me so hard since I've been in this office," and although Israel wanted to avoid a comprehensive settlement, "We see no alternative now to Geneva."

Two days later in a National Security Council meeting, the President addressed the issue of Israeli influence on American foreign policy. Ford told Secretary of Defense James Schlesinger, "As I recall my own experiences as a Congressman, the Israeli representatives float very freely on Capitol Hill. Now we can't do anything about that with Congress. But I have the impression the Israeli representatives are almost as free in many Departments as they are with Congress. You must try to control that." Schlesinger responded, "It is very difficult to handle." But Ford maintained, "The proper relationship should be businesslike but arms-length and

\footnotetext{
${ }^{36}$ Memorandum of Conversation, Ford, Kissinger and Scowcroft, March 26, 1975, Memcons, Box 10, March 26, 1975 - Ford, Kissinger, GRFL. Kissinger also cited "three million Greeks" along with Israelis for "running American foreign policy." Kissinger was referring to pro-Greek lobbying efforts in response to Turkey's invasion of Cyprus.

${ }^{37}$ Memorandum of Conversation, Ford, Kissinger, Scowcroft, and Max Fisher, March 27, 1975, Memcons, Box 10, March 27, 1975 - Ford, Kissinger, Max Fisher, GRFL.
} 
aloof." ${ }^{38}$ However, that posture would be difficult to maintain given the close relationship between the U.S. government and the Israeli lobby. ${ }^{39}$ Moreover, as discussed in the next chapter, the Israeli embassy also played a crucial role in organizing meetings with U.S. officials.

While the Ford administration threatened Israel with the possibility of a comprehensive settlement, Kissinger knew the pitfalls along that path. Almost inevitably, the conference in Geneva would devolve into a wild shouting match. Israel would refuse to seat the PLO, which in Arab eyes represented the Palestinian people and therefore needed to participate in the discussions. The Soviets, acting as a lawyer and advisor for Arab nations, would clamor for an immediate Israeli withdrawal. Pressure would also come from Europe and Japan over energy concerns. No longer in control of the process, the influence of the United States would be neutralized, to a significant degree, by world opinion. The result could be a stalemate that furthered the risk of war.

But there was another option: the United States could simply pressure Israel to withdraw from the occupied territories. In the words of Kissinger, the U.S. was "literally their [Israel's] only friend in the world." ${ }^{40}$ This intimate relationship was reflected in the staggering figures of U.S. aid to Israel. Following the 1973 War, the U.S. appropriated $\$ 3.3$ billion in assistance to Israel. Of that total, nearly $\$ 2.8$ billion was for military assistance, while the remaining $\$ 500$

\footnotetext{
${ }^{38}$ Minutes: National Security Council Meeting, March 28, 1975, National Security Adviser: NSC Meeting File, Box 1, NSC Meeting, March 28, 1975, GFRL.

${ }^{39}$ The Israeli lobby was becoming a powerful force in American foreign policy. Regarding the lobby's influence on US foreign policy, two particular organizations deserve mention - the Conference of Presidents of Major American Jewish Organizations (President's Conference) and the American Israel Public Affairs Committee (AIPAC). While the President's Conference attempts to influence the White House, AIPAC aims for congressional influence. According to Robert Trice, these two organizations "funnel the bulk of articulate Jewish opinion on policy issues to governmental decision-makers," and thereby influence US foreign policy on a level rivaled by few, if any countries. For additional information, see Robert H. Trice, Interest Groups and the Foreign Policy Process: U.S. Policy in the Middle East, Sage Professional Papers: International Studies Series, Volume 4 (Beverly Hills: Sage Publications, Inc., 1976) and John J. Mearsheimer and Stephen M. Walt, The Israeli Lobby and U.S. Foreign Policy (New York: Farrar, Straus and Giroux, 2007).

${ }^{40}$ Minutes: National Security Council Meeting, March 28, 1975, National Security Adviser: NSC Meeting File, Box 1, NSC Meeting, March 28, 1975, GFRL.
} 
million was for economic aid. In total, "Israel has used over \$600 million in U.S. Government assistance to purchase military equipment through commercial (non-U.S. Government) channels, bringing total sales of U.S. military equipment to Israel since the October War to more than $\$ 3.3$ billion." Specifically, the U.S. sent 700 tanks, 55,147 anti-tank missiles, 2,583 trucks, 76 cargo carriers, an assortment of aircraft (F-4, A-4, and C-130) totaling 162 units, along with other various items. ${ }^{41}$

An essential component of reassessment was the freezing of American aid to Israel. Ford intended to withhold further aid as a way to 'persuade' Israel to reconsider its inflexible position. Based on American intelligence, Kissinger estimated that U.S. military assistance had put Israel "in a position to fight an intensive war for almost four weeks without resupply." 42 These were seemingly comforting figures. But considering Israel had faced the realities of warfare since the country's founding in 1948, and also that the Jewish state relied entirely on foreign military aid, further shipments from the U.S. were seen as vital. This point was made to Richard Nixon time and time again (discussed in Chapter 3). More generally, Kissinger observed that "Israel is, for the first time, vulnerable economically, and continuing U.S. assistance is essential because Israel is running an annual budget deficit of over \$2 billion which it expects the U.S. Government to cover. ${ }^{\circ 3}$ Psychologically, with the threat of war ever-present in the Middle East, the freezing of aid to Israel was the bite that complemented the bark of reassessment. And Ford was prepared to draw a line in the sand regarding aid to Israel in relation to movement in peace negotiations.

\footnotetext{
${ }^{41}$ These figures were obtained from a memorandum written by Clinton Granger and Robert Oakley sent to Scowcroft on May 6, 1975. In line with the secrecy that seems to be a staple of the U.S.-Israeli relationship, Oakley recommended, "Probably it would be better not to release them [the figures] to the press and public, but they can certainly be used to good effect with Congress and others in private." Granger and Oakley to Scowcroft, "U.S. Assistance to Israel," May 6, 1975, Presidential Country Files for Middle East and South Asia, 1974-1977, Box 15, Israel (8), GRFL. For additional information on U.S. aid to Israel, see Kristin L. Ahlberg, Transplanting the Great Society: Lyndon Johnson and Food for Peace (Columbia: University of Missouri Press, 2008).

${ }^{42}$ Kissinger to Ford, "Discussion of Middle East Strategy," April 21, 1975, Presidential Country Files for Middle East and South Asia, 1974-1977, Box 1, General (8), GRFL.

${ }^{43}$ Ibid.
} 
On April 14, Ford and Kissinger met with four Middle East ambassadors - Kenneth Keating (Israel), Hermann Eilts (Egypt), Thomas Pickering (Jordan), and Richard Murphy (Syria) - to discuss the feasibility of a comprehensive settlement. Kissinger mentioned the possibility of either trying for an agreement similar to the one sought in March, or going for a more substantial interim step that would have involved "nonbelligerency in exchange for [Israel] moving half or two-thirds back in the Sinai." But of all the options, he concluded, "the best is to come up with a comprehensive plan. It would give us something to stand on with the Arabs. We would be taking on the Israelis, but for something more significant than the line through the passes. It would make the interim stages easier under an overall umbrella." ${ }^{44}$ Keating, who also favored a comprehensive plan, cited the economic impact of reassessment: "Economically, they [Israel] are in serious trouble. Forty percent of their budget goes to defense. Inflation is running $30-40 \% .{ }^{" 45}$ Ford vowed that, "Until we get progress there will be no request for Israeli aid. If Congress tries to force it, I will veto it." ${ }^{\prime 46}$

The significance of the meeting rests not only on the fact that the White House was lining up to pursue a comprehensive plan, but also that Kissinger divulged Israel's intention of keeping large tracts of land taken during the Six Day War in 1967. Israel, according to Kissinger, was bent on keeping "half the Golan, a third of the Sinai, and a third to a half of the West Bank" 47 not to mention full control of Jerusalem. Such a position was in direct violation of the spirit of UN Resolution 242. He later said that Israel wanted peace with the Arabs and aid from the U.S., but "they don't want to pay a price." ${ }^{48}$ The vast majority of the United Nations wished Israel to

\footnotetext{
${ }^{44}$ Memorandum of Conversation, Ford, Kissinger, et al., Memcon, April 14, 1975, NSA: MC, Box 10, April 14, 1975: Ford, Kissinger, U.S. Ambassadors Keating (Israel), Eilts (Egypt), Pickering (Jordan), Murphy (Syria), GFRL.

${ }^{45}$ Ibid.

${ }^{46}$ Ibid.

${ }^{47}$ Ibid.

${ }^{48}$ Ibid.
} 
withdraw to essentially its 1967 borders. The U.S. had sought the same objective but had been allowing Israel to move slowly toward that goal. Yet Israel, according to Kissinger, did not intend to comply. Israel was convinced it could have both territory and peace, which the Arab states would never allow. Although a modest adjustment to the 1967 borders was understandable and even expected, at the same time, the U.S. government planned for Israel to withdraw to roughly the status quo prior to the June War in 1967.

From the Israeli perspective, the occupied territories served a variety of useful purposes. Most importantly, Israel believed the adjusted borders following the 1967 war offered the Jewish state a heightened degree of security. The surprise attack of October 1973 demonstrated the need for expanded borders - if Israel had withdrawn from the territories, the Arab attack could have reached Jerusalem or Tel Aviv. The occupation of the West Bank, and especially all of Jerusalem, was motivated by religious considerations; Jerusalem was the holiest Jewish city which at long last had been brought back into the fold. In addition, Israel hoped the seizure of territory would produce economic benefits, especially with the oil fields in the Sinai.

When King Hussein of Jordan visited Washington on April 29, his comments focused on the impossibility of peace without an Israeli withdrawal. "From the Arab point of view," said Hussein, "it is a question of territory or peace. The combination for the Israelis of territory and peace is an impossibility." ${ }^{49} \mathrm{He}$ went on to say, "The Israelis are masters at long-range planning. We conclude from their actions that their plan is to secure the area. They have been able to obtain and build up great military strength superior to what they have ever had before. But with all that military strength, they cannot guaranty [sic] a peace in the area." ${ }^{, 0}$ Equally troubling, the

\footnotetext{
${ }^{49}$ Memorandum of Conversation, Ford, Kissinger, Jordanian King Hussein, et al., Memcon, April 29, 1975, NSA: MC, Box 11, April 29, 1975: Ford, Kissinger, Jordanian King Hussein, GFRL.

${ }^{50} \mathrm{Ibid}$. At this point (though further research may prove otherwise), there is no concrete evidence to suggest Hussein had any idea that Israel had professed to Kissinger their desire to hold onto significant chunks of territory.
} 
King had an ominous feeling that the moment for constructing a lasting peace may be lost: "The Arab leaders and people are losing hope, and I find the situation very, very alarming. We may now be facing our last chance to make progress for the area and the world." ${ }^{11}$ With Israel refusing to relinquish territory that Arabs regarded as their rightful possessions, Hussein's comments portended a conflict that would involve many actors and continue for years thereafter.

The King's assessment of Israeli intentions was probably right, and Kissinger knew it. In a detailed, telling memorandum written for President Ford a week before the meeting with Hussein, titled "Discussion of Middle East Strategy," Kissinger blasted the Israeli position. Citing a recent statement made by Israeli Defense Minister Shimon Peres, Kissinger claimed the Israelis were using "an Egyptian-Israeli second-stage agreement as a means of avoiding having to move in any serious way in any other negotiations for as long as possible." ${ }^{, 2}$ The Israelis were probably "trying to stall through the presidential elections of 1976," aware that Ford would be reluctant to tackle such a divisive issue. ${ }^{53}$ Just as Hussein predicted the future continuation of the conflict, Kissinger, too, had his eye on what was bound to happen: "Israel would like to 'take Egypt out of the war' alone; however, Sadat could not long survive making a separate peace." 54 And Kissinger reminded Ford, "The basic point to keep in mind is that Israel wants to keep half of the Golan Heights and a third of the Sinai for security purposes, plus a third to a half of the West Bank and all of Jerusalem for security, religious, and economic reasons. ${ }^{" 55} \mathrm{He}$ countered this position by saying, "Changes in Israel's 1967 boundaries will be an inconsequential addition to Israel's security, particularly in an era of modern weapons, if Israel's increasingly powerful

\footnotetext{
51 Ibid.

52 Kissinger to Ford, "Discussion of Middle East Strategy," April 21, 1975, Presidential Country Files for Middle East and South Asia, 1974-1977, Box 1, General (8), GRFL.

${ }^{53}$ Ibid.

${ }^{54}$ Ibid. Israel did 'take Egypt out of the war' with Camp David, and Sadat, true to Kissinger's prediction, was assassinated in 1981 by army members connected to Islamic Jihad for negotiating a separate peace with Israel. 55 Ibid.
} 
Arab neighbors are bent on Israel's destruction over an historical period. ${ }^{56}$ In fact, Kissinger held Israel responsible for the 1973 war, saying "that the Israeli strategy of standing pat and playing for time - of making ostensibly conciliatory statements about wanting a settlement but actually standing fast in the hope of forcing Arab territorial concessions - had produced the stalemate which led eventually to the October 1973 war." ${ }^{57}$ In conclusion, Kissinger recommended, "On balance, the greatest advantage seems to lie with trying for an overall settlement. ${ }^{58}$ Ford had always wished to pursue a comprehensive plan and now Kissinger was giving his support to the idea.

But to impose a full settlement on Israel, Kissinger advised Ford, "We would also have to develop firm Congressional and public support in the U.S. for this course, which Israel may attempt to slow." To do so, Kissinger gave Ford a choice that in retrospect he should have taken, but never did. He informed the President, "the basic choice the U.S. faces is whether to opt for a course that masks the real Israeli strategy or one that deals openly with the issues that must be resolved if there is to be a peace settlement. If we are to choose the latter course, we will have to take into account the additional factor that the Jewish leadership in the United States will add a vocal and highly organized voice in support of what will be firm Israeli opposition to this course. ${ }^{" 59}$ When talking with Israeli officials or members of the American Jewish community, Kissinger also threatened to release a "white paper" that defended the Administration's position, which is discussed in the next chapter. One can only assume that "the real Israeli strategy" being kept from the public was the way in which Israel had manipulated the peace process in order to make a separate peace with Egypt and remain in much of the occupied territories. Kissinger

\footnotetext{
${ }^{56}$ Ibid.

${ }^{57}$ Ibid.

${ }^{58}$ Ibid. Kissinger also recommended a comprehensive peace during the meeting with the ambassadors.

${ }^{59}$ Ibid. Kissinger had also told Ford on March 27, 1975 that "If the Jewish Community comes after us, we will have to go public with the whole record."
} 
figured that by making the strategy public, both Congress and the American people would see clearly how Israel was more interested in territory than peace, regardless of the effect on the United States. Armed with blunt facts, the Ford administration could rally the political support necessary to impose a settlement on Israel and bring the conflict nearer to a close.

The day after King Hussein's visit to the White House, Saigon capitulated to North Vietnamese forces and the Vietnam War had finally ended. Importantly, the bad blood between the executive and legislative branches engendered by the Vietnam War carried over into other areas of U.S. foreign policy, including Middle East policy. Just when the Ford administration needed the support of Congress and a unified American front to execute a foreign policy objective in the Middle East dating back to the summer of 1967, Congress was poised to continue its trend of challenging the executive branch and asserting more influence on foreign policy matters. The White House, not Capitol Hill, was responsible for the quagmire in Southeast Asia, and the fall of Saigon was a pointed reminder of executive mismanagement of foreign policy. But in the course of becoming more involved in American foreign policy, the Senate undermined the Ford administration's reassessment of U.S. policy as well as any possibility of achieving a final, meaningful peace settlement in the Middle East.

\section{Senate Subcommittee}

Senator George S. McGovern, a South Dakota Democrat, and Senator Charles H. Percy, an Illinois Republican, together served as the ranking members of the Senate Foreign Relations Subcommittee on Near Eastern Affairs in 1975. The subcommittee was as close as Congress could come to an oversight of the executive branch's foreign policy in the region. Each senator had conducted an exploratory visit to the Middle East in the first half of 1975. Percy's trip, from 
January 3 to January 25, included thirteen different destinations with considerable time spent in both Egypt and Israel, just before Kissinger's two shuttles in February and March. ${ }^{60}$ McGovern, the chairman of the subcommittee due to the Democratic majority in the Senate, visited Egypt, Saudi Arabia, Lebanon, Jordan, Syria, Israel, and Iran between March 21 and April 9, 1975; the first part of McGovern's trip coincided with the failure of talks between Egypt and Israel. ${ }^{61}$ McGovern cabled Kissinger his impression of a March 24 meeting with Sadat, and in late March, Kissinger responded, "I appreciate your sharing with me the substance of the discussion ... As you know, we are in the process of reassessing our policy in the Middle East ... I look forward, therefore, to seeing you on your return when we can share impressions and views on the Middle East situation. ${ }^{962}$

Neither McGovern nor Percy cared much for step-by-step diplomacy, at least the way Kissinger administered the process in the Middle East. The steps seemed aimless to the senators, existing as trivial agreements without a final goal. McGovern offered a useful analogy: "I believe that a 'step-by-step' approach to peace is not now possible in the Middle East until the general outline of a final settlement is worked out ... it is not practical to mount a ladder until there is a definite structure against which to lean the ladder. Although I believe such a structure must and can be built, its absence today is not the fault of any single nation.." ${ }^{93}$ Similar to the White House, McGovern was careful not to publicly single out Israel as being the primary obstacle to peace in the Middle East. Rather, McGovern explicitly cited Kissinger's diplomatic method - not Israel -

\footnotetext{
60 "The Middle East," A Report by Senator Charles H. Percy to the Committee on Foreign Relations United States Senate, April 21, 1975 (Washington: U.S. Government Printing Office, 1975), v. In addition to Israel and Egypt, Percy also visited Iran, Kuwait, Bahrain, Qatar, Abu Dhabi, Dubai, Oman, Saudi Arabia, Lebanon, Syria, and Jordan.

61 "Realities of the Middle East," A Report by Senator George S. McGovern to the Committee on Foreign Relations United States Senate, May 1975 (Washington: U.S. Government Printing Office, 1975), v.

${ }^{62}$ Telegram from Secretary of State to American Embassy in Beirut, "Message for Senator McGovern," March 28, 1975, Presidential Country Files for Middle East and South Asia, 1974-1977, Box 25, Lebanon-State Department Telegrams, GFRL.

63 "Realities of the Middle East," 1.
} 
as the primary reason for the failure of talks: "As this report indicates," states McGovern, "the breakdown of 'step-by-step' diplomacy was not caused fundamentally by Israel, or by Egypt and the Arab States, as some have charged and many have assumed. Rather, the breakdown was inherent in a diplomatic tactic which seemed logical but was lacking in the essential foundation of a diplomatic strategy: Neither side knew where the steps would finally lead." ${ }^{\prime 4}$ McGovern believed it was first necessary to outline a final peace settlement; only then could the participants step toward a common goal.

McGovern's suggestion resembled Secretary of State Rogers's plan during President Nixon's first term in that he recommended a final agreement to be worked out first, followed by a gradual implementation of the peace plan. But Israel balked at the idea in 1970-71 because if the final arrangements were pre-determined, then there was no need for negotiations because the conclusion was a fait accompli. For Israel, the process of direct negotiations between the combatants was a crucial step towards peace because the act of negotiating implied recognition of the state of Israel, and was necessary for establishing political dialogue and more normal relations.

McGovern's final plan, regarding the Palestinians and border disputes, was nearly identical with that put forward by Percy. The solution called Palestinian self-determination in the West Bank and Gaza Strip, and recognition of Israel. Israel, in return for a formal peace treaty and recognition of statehood, would be able "to enter into a territorial settlement approximating the 1967 borders with practical modifications." ${ }^{65}$ Furthermore, McGovern goes on to say, "I would also urge them to state publicly that in this context, Israel acknowledges the right of the

\footnotetext{
64 "Realities of the Middle East," 1.

65 "Realities of the Middle East," 27-28.
} 
Palestinian people to live on the West Bank and in Gaza."66 The Senator's plan for peace involved a full settlement that included as Israeli withdrawal to essentially its 1967 borders and self-determination for Palestinians in the West Bank and Gaza, in essence, echoing the Johnson administration's principles of territorial integrity and political independence for all people in the Middle East.

McGovern did not dismiss outright a step-by-step means for implementing a final agreement. Perhaps after determining final goals a comprehensive peace plan could be implemented by way of steps. Then the belligerents would be walking in step on the road to a fully-defined peace. McGovern did not disapprove of step-by-step diplomacy per se; he disapproved of its creator's avoidance of core disputes and the absence of an agreed-upon final peace.

While Kissinger had intentionally avoided the two most vexing disputes - Israel's occupation of Arab land and the status of the Palestinians - Percy recognized that no lasting peace could ignore these topics, which lay at the heart of the Arab-Israeli conflict. "What is critically important now," Percy related, "is to resolve this central political, historical and emotional Palestinian 'problem,' for until it is successfully resolved - until, I believe, the Palestinians are given a homeland of their own - there will be no peace in the Middle East, no security for Israel, no end to the killing." ${ }^{\circ 7}$ Percy also predicted "there will be no peace for Israel, no security for Israel, until she withdraws from most of the lands she has occupied since the 1967 war." ${ }^{98}$ And Percy was a staunch supporter of Israel. "But it is precisely because I care deeply

\footnotetext{
66 "Realities of the Middle East," 28.

67 "The Middle East," 18.

68 "The Middle East," 5.
} 
about Israel and her future well-being," states Percy, "that I now recommend changes in her policy vis-à-vis her Arab neighbors." 69

For Percy, a resolution to the border conflict could simultaneously serve to provide the Palestinians with a homeland. Worth noting, the Illinois senator called for Israel to return 'most' of the lands it had occupied in the Six Day War; Israel would not budge on Jerusalem and asserted that retention of part of the Golan Heights was necessary for protection against a Syrian attack. ${ }^{70}$ What of the other territories? From Percy's report, in addition to the reattachment of the Sinai Peninsula to Egypt, Israel should also return Gaza and the West Bank to the Palestinians, who numbered 390,000 and 640,000 people in the respective areas. ${ }^{71}$ By acquiring Gaza and the West Bank, the Palestinian people would have the actual land necessary to seriously petition the United Nations for statehood.

Implicit in Percy's plan, as it was explicit in McGovern's, was a rejection of Kissinger's approach to the peace process. Percy was certainly aware of Kissinger's string of small victories in the Middle East, and those agreements carefully and intentionally excluded any meaningful discussion of either borders or the Palestinians. With such strong sentiments regarding the divisive issues, Percy was essentially imploring Kissinger to hurry his steps toward a full settlement plan that dealt directly with the fundamental issues of the Arab-Israeli conflict.

And so in due course the senators transmitted their reports to the Senate: Percy on April 21 and McGovern on May 23. But events had overtaken their analyses. On May 8, Kissinger informed Ford that two senators, Jacob Javits and Henry 'Scoop' Jackson “are circulating a letter on the Hill supporting secure defensible borders" for Israel, and insisting "the U.S. must give

\footnotetext{
69 "The Middle East," 6.

70 "The Middle East," 6.

71 "The Middle East," 17.
} 
military support regardless of what Israel does because it is a bastion of democracy." 72 The letter evolved into an attack on the Ford administration's foreign policy and gained broad senatorial support. Ford recalls in his memoirs, "On May 21, I received a letter signed by seventy-six Senators urging me to 'be responsive' to Israel's request for $\$ 2.59$ billion in military and economic aid. Although I said publicly that I welcomed the letter as an expression of Senate sentiment, in truth it really bugged me. The Senators claimed the letter was 'spontaneous,' but there was no doubt in my mind that it was inspired by Israel." ${ }^{73}$ Ford's suspicion is confirmed by Israeli Prime Minister Yitzhak Rabin, who cites the letter as being the result "of our public campaign in the United States. ${ }^{~} 74$ Additionally, there is evidence the memorandum was drafted, at least in part, by the pro-Israeli lobby, the American-Israel Public Affairs Committee (AIPAC) ${ }^{75}$ As discussed in the next chapter, the Israeli embassy in Washington D.C. - and especially Ambassador Simcha Dinitz - played a central role.

The actual letter itself is quite intriguing. Linked to the demand for resumption of aid to Israel was an equally important goal of the Senate - an increased role in foreign affairs. The letter stated, "Recent events underscore America's need for reliable allies and the desirability of greater participation by the Congress in the formulation of American foreign policy. Cooperation between the Congress and the President is essential for America's effectiveness in the world." Regarding reassessment and Ford's foreign aid requests to Congress, "We trust that your recommendations will be responsive to Israel's urgent military and economic needs. We urge

\footnotetext{
${ }^{72}$ Memorandum of Conversation, Ford, Kissinger, and Scowcroft, Memcon, May 8, 1975, NSA: MC, Box 11, May 8, 1975: Ford, Kissinger, GFRL.

${ }^{73}$ Gerald R. Ford, A Time to Heal: The Autobiography of Gerald R. Ford (New York: Harper \& Row, Publishers, 1979), 287.

${ }^{74}$ Yitzhak Rabin, The Rabin Memoirs, Expanded Edition (Berkeley: University of California Press, 1996), 262. Lenczowski claims, "There were reasons to believe that the letter had been partly drafted by the pro-Israeli lobby, the American-Israel Public Affairs Committee (AIPAC)" (150). Sheehan also claims, "the letter was a stunning triumph for the lobby" (176).

${ }^{75}$ Lenczowski, 150. Sheehan talks about the influence of the lobby as well. More discussion of the Israeli lobby can be found in endnote 38 .
} 
you to make it clear, as we do, that the United States acting in its own national interests stands firmly with Israel in the search for peace in future negotiations, and that this premise is the basis of the current reassessment of U.S. policy in the Middle East." 76

Yet the letter seems far from being an organized attempt to play a measured and constructive role in American foreign policy. After signing, some senators "told journalists privately that they had been pressured to vote against their own best judgment, and expressed admiration for the few senators who resisted." ${ }^{, 77}$ In his memoirs, Senator James Abourezk (DSD) recalls how pro-Israel lobbyists manipulated the political climate by stressing the upcoming presidential election for two Democratic hopefuls - George McGovern and Ted Kennedy (DMA). According to Abourezk, "Lobby operatives took the letter to Senator George McGovern's staff, telling them that Senator Ted Kennedy had already signed it, and that McGovern shouldn't be the only prospective presidential candidate left off the list. Then producing McGovern's signature, they confronted Kennedy's staff with the same ultimatum." ${ }^{.78}$ Abourezk also mentions that one unnamed senator signed the letter against his better judgment, but did so because he received several phone calls from American Jews who had actively worked in his campaign, and who wanted him to sign the letter. ${ }^{79}$ Abourezk was one of the most vocal critics of U.S. foreign policy in the Middle East, which likely skewed his outlook; however Galen Jackson, in his recent article about domestic politics and Sinai II, similarly explains that many senators wavered backand-forth about signing the letter. ${ }^{80}$ Despite reservations, though, more than three-quarters of the Senate signed the letter.

\footnotetext{
${ }^{76}$ Sheehan, 175. Sheehan includes the letter in its entirety.

${ }^{77}$ Curtiss, 103.

${ }^{78}$ James Abourezk, Advise and Dissent: Memoirs of South Dakota and the U.S. Senate (Chicago: Chicago Review Press, 1989), 168.

${ }^{79} \mathrm{Ibid}$.

${ }^{80}$ Galen Jackson, "The Showdown That Wasn't: U.S.-Israeli Relations and American Domestic Politics, 1973-

1975," International Security 39, no. 4, (Spring 2015), 130-169.
} 
After signing, McGovern inadvertently articulated the confusing nature of the letter. He said, "it would be folly for Israel to assume that American support means approval of the existing boundaries in the Middle East. The present boundaries are not defensible; they are a virtual assurance of continued conflict ... In return for ... recognition, Israel must agree to return the occupied territories and must accept Palestinian self-determination, including the right to a political entity of their own." ${ }^{" 81}$ Yet the letter did precisely what McGovern had hoped to avoid! By attacking the White House's reassessment and essentially guaranteeing Israeli aid shipments, the Senate ensured the continuation of Israeli occupation of the disputed territories and the ongoing problem of a stateless Palestinian nation. Percy shrewdly never signed the letter. Being a fellow Republican, his partisan support for President Ford probably convinced the Illinoisan not to scratch his signature on a text that directly undermined the avowed intentions of the executive. Once the document had settled on the President's desk in the Oval Office, 'reassessment' was essentially over. The executive branch would have to bow to the gathered strength of the Senate. This important Senatorial letter will be further analyzed in the chapter.

Roughly three weeks after the fall of Saigon, the Senate's May 21 letter signaled the Ford administration's inability to muster the necessary support to achieve the United States' foreign policy objective in the Middle East. With over three-quarters of the Senate demanding the resumption of American aid to Israel regardless of what Israel did, the White House lost its only true power in the relationship with the Jewish state. Without the threat of discontinuing aid, the presidency had no means for pressuring Israel to accept the type of peace desired by both the White House and the two ranking members of the Senate Subcommittee on Near East Affairs. The possibility of a comprehensive settlement to the Arab-Israeli conflict had been missed. Ford and Kissinger had no choice but to resume a defeated, now truly-aimless, step-by-step process.

\footnotetext{
${ }^{81}$ Sheehan, 175-6.
} 


\section{A Purchased Agreement}

Only five months after negotiations stalled in March, Kissinger took off for yet another shuttle tour of the Middle East on August 20, 1975. This time an agreement was within reach. In order to work out the details, Kissinger visited Cairo and Tel Aviv/Jerusalem seven times each, along with several side trips. ${ }^{82}$ Finally, after lasting through a nonstop session in Jerusalem from 9:30 p.m. August 31 to 6:00 a.m. the following day, the two sides reached an agreement. The text, Sinai II, was officially signed by Israel and Egypt on September 4, $1975 .{ }^{83}$

Like the previous two disengagement agreements, Sinai II did little to change the status quo in the Middle East. However, the agreement was a crucial step in establishing peace between Egypt and Israel. Egypt finally received the Mitla and Giddi passes, along with the oil fields, in return for an Egyptian commitment to resolve any conflict by peaceful means. The Israeli military line in the Sinai moved approximately ten miles back, leaving their position to be filled by the Egyptians. The limited zone was demilitarized to no more than 8,000 men in eight battalions, with 75 tanks and 72 short-range artillery pieces. The United States would man and supervise an early-warning system in the buffer zones as spelled out in detail in the agreement itself. $^{84}$

In order to make the deal acceptable to both parties, the U.S. signed four secret agreements - three with Israel and one with Egypt. With respect to Israel, the U.S. committed itself to supplying Israel with further economic and military assistance, in effect, completing the process began on May 21 to end reassessment and unfreeze Israeli aid requests. Aid to Israel would thus eclipse the $\$ 1$ billion mark, and since then aid levels to Israel have not dipped below

\footnotetext{
${ }^{82}$ Curtiss, 103.

${ }^{83}$ Decade of Decisions, 274.

${ }^{84}$ The details of the agreement are taken from Decade of Decisions, 273-276.
} 
that mark. Moreover, the U.S. agreed to compensate Israel for oil lost by giving up the Abu Rhodeis oil fields, and agreed to consider selling to Israel both F-16 fighter jets and Pershing ground-to-ground missiles, the missiles being originally designed to carry nuclear warheads. Additionally, the U.S. pledged to not recognize the PLO until Israel did, and to not advance any steps in the peace process without first consulting with Israel. Regarding Egypt, the U.S. promised to promote future negotiations between Syria and Israel over the Golan Heights, provide assistance for the early-warning system, and consult with Egypt on any Israeli violations of the agreement. ${ }^{85}$

Reading between the lines of the agreement, the United States bought the interim step between Israel and Egypt. Unable to bring peace to the region through mediation within the U.S.sponsored peace process, the Ford administration paid a high price to salvage the remnants of its Middle East policy. Using secret agreements, aid packages, and empty promises, the presidential approach to the Near East looked eerily similar to a path followed in the Far East, and all without a clear, attainable vision of the future. Yet the interim agreement gave the appearance of another step being taken towards a final settlement. The perception would be that the U.S. was in control of the peace process, although the White House was well aware that a comprehensive peace settlement was unlikely to come about in the near future, if at all.

In light of the White House's handling of Vietnam, not surprisingly, Congress was disturbed by the use of secret agreements and the employment of U.S. personnel to man an early warning station. A statement released by Senator Clifford P. Case (R-NJ) on September 4 stated, "It is my belief that there is no such thing as a valid secret United States commitment." Such commitments, according to Case, "require the approval of the Congress and the American

\footnotetext{
${ }^{85}$ The details of the agreement are taken from Spiegel, 301-302 and Decade of Decisions, 273-276.
} 
people. ${ }^{" 86}$ After Vietnam and Watergate, Congress wanted to dispel the image of secrecy and backroom dealings in Washington. Moreover, Congress was especially reluctant to sign any agreement that included U.S. personnel being employed in the region after all the 'advisors' who went to Vietnam in the 1950s and 1960s. A September 12 White House document communicated that "there is bipartisan concern about the secret elements of the agreement." Many congressional members did not "wish to be party to a secret agreement because of post-Vietnam fears," and thus wanted "to make public as much as possible of the entire agreement." Complicating the situation, the details of the secret agreements were leaked to newspapers and appeared in Washington Post and New York Times articles on September 16, which only added to the atmosphere of mistrust swirling about Washington. In an effort to advance an image of transparency, on October 3 the Senate Foreign Relations Committee "voted 12 to 2 to release the attached documents provided by the Department of State in connection with the Sinai disengagement proposal, ${ }^{\prime 88}$ thereby making public the secret agreements.

Ford and Kissinger tried to allay Congressional fears in a meeting with bipartisan Congressional leadership on September 4. Ford addressed the most problematic portion of the agreement - deploying U.S. personnel to the Sinai buffer zone - by saying, "This part of the agreement is absolutely crucial to the settlement." Neither Israel nor Egypt would agree to personnel from the other side manning the station, and neither side wanted the U.N. to participate after the failure of the United Nations Expeditionary Force to maintain peace in the run-up to war in May 1967; thus, U.S. participation was requested by both sides. Ford added that the National

\footnotetext{
${ }^{86}$ Statement by Senator Clifford P. Case on Congressional Approval of U.S. Personnel in the Sinai Area and Approval of United States Commitments To Israel and To Egypt, From the Office of Senator Clifford P. Case (RNJ), September 4, 1975, Max L. Friedersdorf, Box 14, Middle East, GFRL.

${ }^{87}$ Timetable for House Action on Sinai Agreement, Memorandum for Jack Marsh, September 12, 1975, Max L. Friedersdorf, Box 14, Middle East, GFRL.

${ }^{88}$ United States Senate Committee on Foreign Relations - For Immediate Release, October 3, 1975, Max L.

Friedersdorf, Box 14, Middle East, GRFL.
} 
Security Council "thoroughly discussed" the issue, and that ultimately, "Each member was asked his opinion and I can tell you that all of them agreed that our participation was a good idea and they approved our making such a proposal. ${ }^{" 89}$ Later in the meeting, Speaker of the House Carl Albert (D-OK) responded that "I believe that I am one of the few here who can remember when Secretary of State John Foster Dulles urged the Congress to approve sending 800 technicians to South Vietnam." Albert mentioned, however, that "the situation here is basically different" because "both sides have requested our participation, and we are not putting Americans into an active conflict. These Americans will be civilians, not military." Chairman of the Senate Foreign Relations Committee John Sparkman (D-AL) amended Albert's comment by adding, "Carl, as I recall it, President Eisenhower sent in military advisors, not technicians." ${ }^{90}$ Albert followed by saying, "I want to reiterate that I see a substantial difference between the current proposal and the Vietnam situation.” But Senate Majority Leader Mansfield was worried about sending technicians: "I am very much concerned that the United States for the first time is making a commitment of personnel to the Middle East. Whether they are military or civilian is beside the point." ${ }^{.11}$ Between the promise of U.S. personnel and sizeable aid packages, for Mansfield, "All of this seems to me to be a pretty stiff price to pay for a very small withdrawal."${ }^{92}$

The wounds from the Vietnam War ran deep in the Congressional body. After Congress failed to take action on the agreement for several weeks, Ford wrote a letter to Speaker Albert on September 29 imploring Congress to approve the agreement. In order to dispel worries about potential secrecy from the White House, Ford stated that "All relevant papers and all U.S.

\footnotetext{
${ }^{89}$ National Security Council Meeting with Bipartisan Congressional Leadership, Memorandum for the Record, September 4, 1975, National Security Advisor, NSC Press and Congressional Liaison Staff: Files, 1973-1976, Box 8, September 4, 1975 - Bipartisan Leaders (MEMCON - Middle East Agreement), GFRL.

${ }^{90}$ Ibid.

${ }^{91}$ Ibid.

${ }^{92}$ Ibid.
} 
commitments related to the Agreement have been submitted to the appropriate committees of the Congress. ${ }^{993}$ But the Senate Foreign Relations Committee took issue with Ford's letter. In a demonstration of mistrust and lack of faith in the White House, the Committee attached resolutions to the agreement so that the Committee would be informed "about all undertakings and assurances related to the agreement and, most importantly, confirm to the Committee that there are no other existing undertakings or assurances related to the agreement." According to Les Janka of the National Security Council, the resolutions were drafted "after the President's letter of last night was received and it is, to quote [Senator] Case's staffer, to be seen as an ultimatum reflecting the fact that the committee considers the President's letter as inadequate when it says, 'All relevant papers and all U.S. commitments related to the agreement have been submitted to the appropriate committees of the Congress." ${ }^{\prime 9}$

Joseph J. Sisco, Kissinger's Under Secretary of State for Political Affairs, defended the White House's agreement in his statement before the House of Representatives. Pleading with the House, Sisco said the administration was "going to extraordinary length in trying to share this information with the committee and the Congress because we were very, very conscious of the atmosphere that exists in our country. We have all gone through a pain and an anguish in terms of Vietnam and there isn't any family in this room that hasn't been touched by the Vietnam situation." Sisco was cognizant of the strain between the two branches of government when he said, "I know there isn't a great deal of trust in this town but I hope that we can begin to develop the kind of confidence between the executive branch and the legislature which I think is

\footnotetext{
${ }^{93}$ Ford to Albert, September 29, 1975, Max L. Friedersdorf, Box 14, Middle East, GFRL, 2.

${ }^{94}$ Janka to Scowcroft, "SFRC Action on the Sinai Agreement," September 30, 1975, Presidential Country Files for Middle East and South Asia, 1974-1977, Box 15, Israel (14), GRFL.
} 
necessary for us to move together as a country." ${ }^{95}$ In the end, both the House and Senate approved the placement of American technicians in the Sinai, but the Senate, in particular, voiced its displeasure over the use of executive agreements without Senate participation (discussed in Chapter 7).

Congress ultimately signed off on Sinai II, an important agreement between Israel and Egypt that would be followed a few years later by the Camp David Peace Accords, which secured a final peace between Egypt and Israel. In short, Israel was able to take Egypt out of the Arab-Israeli conflict and hold onto the rest of the territories taken in the June 1967 Arab-Israeli War. Yet the Ford administration made sincere efforts to bring the Arab-Israeli conflict and peace process to a close. But after the misdeeds of previous administrations, the White House was at a power disadvantage vis-à-vis Congress, and quite obviously the two branches were walking out of step when it came to U.S. peace initiatives in the Middle East. Without the threat of discontinuing aid, the White House had no choice but to get behind an Israeli plan that was at odds with American foreign policy, a plan paradoxically supported by congressionally-approved American funds and against the recommendations of the Senate Subcommittee's two ranking members. Indeed, the situation points to deeper, fundamental problems in the formation and execution of American foreign policy.

The story of Sinai II displays an already-beleaguered White House further hampered by its own choice to conceal Israeli intentions about the occupied territories, and a Congress groping for a participatory role in a failing foreign policy. Naturally, this counterproductive situation was

\footnotetext{
95 "Middle East Agreements and the Early Warning System in Sinai," Hearings of the Committee on International Relations for the House of Representatives, Ninety-Fourth Congress, First Session on The Middle East Agreements and Legislation to Implement the United States Proposal for the Early-Warning System in Sinai (Washington: U.S. Government Printing Office, 1975), 29.
} 
laden with problems. The Ford administration knowingly and willingly continued the executive trend of keeping the United States public and representative body in the proverbial dark about the nature and development of U.S. foreign policy in the Middle East; the administration made no attempt to enlighten the American people about the hush-hush elements of Israeli foreign policy or the immodest efforts by the Israeli lobby to redirect American foreign policy. For its part, Congress sided with pro-Israel elements - especially the Israeli embassy - and in so doing overstepped its boundary with respect to foreign policy. While granted the constitutional right to appropriate foreign assistance, as the May 21 letter shows, the Senate recognized foreign policy was still the domain of the White House, which is why the Senate asked President Ford to be responsive to aid requests.

The inescapable conclusion is that bitter executive-legislative relations thwarted the Ford administration's effort to bring about a lasting peace in the Middle East. The United States government had been badly damaged by the tumultuous domestic and international events of then-recent years - Vietnam, student protests, Watergate, to name a few - and at the end of the day, the misfiring of the U.S. government rendered impotent the most powerful polity on the planet.

While events unrelated to the Middle East played a large role in creating the animosity between the two branches, the State of Israel - and especially Israeli Ambassador in Washington D.C., Simcha Dinitz - used that tension to its favor during the reassessment period. Dinitz, along with other Israeli officials and leaders in the American Jewish community, managed to successfully exploit the strife between Congress and the Ford administration. The idea for the Senate letter of May 21 came from Dinitz, not a U.S. official, which is discussed in the next chapter. 


\section{The Spirit of the 76: The Israeli Embassy and President Ford's Reassessment}

President Gerald Ford's "reassessment" of U.S.-Middle East policy, which included an immediate freeze on all aid to countries in the region, ushered in one of the most contentious periods in U.S.-Israel relations. After negotiations for a Sinai II agreement failed in March 1975, President Ford and his Secretary of State and National Security Adviser Henry Kissinger privately blamed Israel for sabotaging the peace talks with Egypt, and publicly insinuated that Israel was responsible for the breakdown of talks. Ford and Kissinger believed that the Israelis were intentionally stalling in order to remain in the occupied territories, and stymied disengagement talks with Egypt to resist momentum towards a comprehensive peace arrangement. The Administration desperately needed another disengagement agreement to advance the momentum created by Kissinger's ongoing step-by-step diplomacy. Kissinger's diplomatic process had intentionally aimed to shield Israel from external pressures - especially the Soviet Union, Europe, and the Palestine Liberation Organization (PLO) - to relinquish territory taken in 1967 until Israel was prepared to do so. But Israel was expected to eventually relinquish the vast majority of the lands taken in 1967 . Thus, reassessment was a way of punishing Israel for not going along with American diplomacy, which had been designed by Kissinger to benefit both Israel and the United States.

The act of freezing aid to Israel, as well as publicly suggesting that Israel was to blame, brought about a public relations campaign from Israel. In certain situations, Israel has used a hasbara, which means general political public relations, to influence public opinion in the United States. Peter Hahn discusses several hasbara efforts by Israel during the Presidencies of Harry Truman and Dwight Eisenhower in his important work, Caught in the Middle East, as well as a 
separate article based on his research conducted at the Israel State Archives in Jerusalem. ${ }^{1}$ Rather than disseminating ideological messages or propaganda, the Jewish state uses a hasbara to advance the Israeli position by attempting to influence U.S. public opinion, and ultimately U.S. policy, through meetings with U.S. government officials, coordination with American Jews, messages through the press, and lectures given by Israeli officials. Similar to the experiences of the Truman and Eisenhower administrations, the Israeli hasbara in the spring of 1975 meant a head-on collision with the Ford administration.

Relying on research gathered at the Israel State Archives in Jerusalem, this chapter charts the efforts of the Israeli embassy in Washington D.C. to assist the Israeli hasbara in the U.S. between late March and late May 1975, the main period of reassessment. ${ }^{2}$ The Israeli embassy worked tirelessly to explain the Israeli position to U.S. congressional leadership and also used meetings with congressional assistants and lower-level officials from the executive branch to access important information, which was sent back to Jerusalem. Additionally, the embassy coordinated its efforts with the leadership of the American Jewish community, and at times Israeli Ambassador Simcha Dinitz even "prepared" individuals for their meetings with Ford and Kissinger. Ultimately, the ability of the Israeli embassy to work with American Jews and the U.S. Senate led to a May 22 letter signed by 76 senators that undermined reassessment. Referred to by some Israeli officials at the time as "the spirit of the 76," the letter was a tremendous

\footnotetext{
${ }^{1}$ Peter L. Hahn, Caught in the Middle East: U.S. Policy toward the Arab-Israeli Conflict, 1945-1961 (Chapel Hill: The University of North Carolina Press, 2004). One of the first hasbara efforts by Israeli leaders discussed by Hahn was a "sweeping public relations campaign" to overcome Pentagon and State Department reluctance to supply Israel with arms in 1950 (73). Peter Hahn, "The View from Jerusalem: Revelations about U.S. Diplomacy from the Archives of Israel," Diplomatic History 22, no. 4 (Fall 1998): 509-532.

${ }^{2}$ This chapter relies almost exclusively on Hebrew-language documents from the Israel State Archives. I am indebted to the excellent work of my research assistant Jonathan Matthews, who translated all of the documents discussed below. Over the course of two weeks, Jonathan and I went through a series of papers from the Office of the Foreign Ministry that included extensive discussions between Jerusalem and the Israeli embassy in Washington. Jonathan carefully dictated to me the contents of the documents while I typed, and we spent a great deal of time discussing the appropriate word choice for translation. Additionally, Jonathan was a tremendous help in explaining and discussing Israeli politics during this time period.
} 
achievement for Israel, thanks in large part to Dinitz, who first proposed the idea of such a letter to Foreign Minister Yigal Allon in late April.

Historians are divided about Ford's reassessment, especially the impact of domestic politics on U.S. foreign relations in the Middle East. Steven Spiegel claims the Senate letter of 22 May probably mattered little because Kissinger and Ford had already determined to restart step-by-step diplomacy. ${ }^{3}$ On the other hand, William Quandt believes the Senate letter forced the Administration to recognize that further pressure on Israel would be "politically counterproductive," and consequently the Administration had no choice but to resume step-bystep diplomacy in the absence of an obtainable general peace agreement. ${ }^{4}$ Salim Yaqub sees Ford's reassessment as an exercise of "political theater," and that Kissinger only meant to shield Israel from external pressures in order to secure indefinite Israeli occupation of the disputed territories. ${ }^{5}$ In that case, domestic politics mattered little because the U.S. would not force a peace agreement on Israel. A recent article by Galen Jackson suggests that domestic politics, especially the activities of the pro-Israel lobby, certainly influenced Ford's reassessment. Yet the Ford administration decided to not have a showdown with Israel largely because Kissinger feared rising anti-Semitism in the United States. ${ }^{6}$ Jackson attempts to refine the argument by John Mearshimer and Stephen Walt about the power of the pro-Israel lobby, admitting that the

\footnotetext{
${ }^{3}$ Steven Spiegel, The Other Arab-Israeli Conflict: Making America's Middle East Policy, from Truman to Reagan (Chicago: The University of Chicago Press, 1985), 297.

${ }^{4}$ William B. Quandt, Peace Process: American Diplomacy and the Arab-Israeli Conflict since 1967, Third Edition (Washington D.C.: Brookings Institution Press, 2005), 165.

${ }^{5}$ Salim Yaqub, "The Weight of Conquest: Henry Kissinger and the Arab-Israeli Conflict," in Nixon in the World: American Foreign Relations, 1969-1977, ed. Fredrik Logevall and Andrew Preston (New York: Oxford University Press, 2008), 227-248.

${ }^{6}$ Galen Jackson, "The Showdown That Wasn't: U.S.-Israeli Relations and American Domestic Politics, 1973-1975," International Security 39, no. 4, (Spring 2015), 130-169. Kissinger spoke about his fear of rising anti-Semitism in the U.S. while meeting with Jewish intellectuals on 30 March, which is discussed below.
} 
lobby mattered, but not in such a decisive way as Mearshimer and Walt suggest. ${ }^{7}$ Yet scholarship has overlooked the very important role played by the Israeli embassy and especially Dinitz, both aside from and in coordination with the pro-Israel lobby.

The result was a ferocious, behind-the-scenes battle between Israel and the U.S. for the heart of the peace process, which threatened to damage both U.S-Israel relations and IsraelEgypt relations. Israel successfully used its hasbara campaign to challenge an exceptionally weak presidential administration during a difficult time. The unelected Ford had to navigate the fall of Saigon and an increasingly poor U.S. economy, both blamed on inept executive leadership. At the same time, Ford faced a strong challenge from a coordinated Israeli effort that aimed to reframe the nature of reassessment to prevent the deterioration of U.S.-Israel relations, and use the U.S. Congress to secure future aid agreements and deliveries. The state of Israel clearly influenced the U.S. Congress and public opinion, which in turn impacted U.S. foreign policy in nontrivial ways. In particular, the "spirit of the 76 " letter demonstrated not only the significant power of the Israeli lobby in shaping U.S.-Israel relations, but also the increasing power of Congress in making U.S. foreign policy.

The failure of the March negotiations was due to a seemingly small misunderstanding. Kissinger had traveled to the Middle East in early March on the assumption that Israel and Egypt had agreed to negotiate another disengagement agreement. The Egyptians wanted territory in the Sinai; specifically, they wanted the strategically important Mitla and Giddi passes, along with control over the Abu Rudeis and Ras Sudr oil fields. Although Israel hoped for an Egyptian pledge of non-belligerency, Israeli Prime Minister Yitzhak Rabin had stated during an interview

\footnotetext{
${ }^{7}$ John J. Mearshimer and Stephen M. Walt, The Israel Lobby and U.S. Foreign Policy (New York: Farrar, Straus and Giroux, 2007).
} 
in February that Israel would give up the specific territory in return for an Egyptian commitment to not go to war, or threaten with force, as part of an effort to reach peace. ${ }^{8}$ But the Israeli negotiating team caught Kissinger by surprise in March when it insisted that Egypt agree to nonbelligerency. For Sadat, that meant acceptance of the status quo, which he recognized would alienate the Arab world. So Sadat rejected the Israeli proposal and instead offered "nonuse of force," which in turn met with an Israeli rejection. As negotiations headed for collapse, not even a stern letter from President Ford on March 21, 1975, softened the Israeli position. The disengagement agreement between Israel and Egypt then quickly deteriorated and fell apart.

Looking deeper, however, reveals that the failure of negotiations had much more to do with the peace process as a whole than a single disengagement agreement between Israel and Egypt. Ford and Kissinger badly needed an agreement to keep "stepping" forward, and they felt betrayed by the Israelis. When House Majority Leader Thomas “Tip" O'Neill (D-MA) met with Prime Minister Rabin in early April, he mentioned that, according to Ford, Israel was told 24 times before Kissinger's March shuttle it would not receive non-belligerence from Egypt as part of an agreement, and each time Israel said to continue with negotiations. ${ }^{9}$ Therefore when Israel demanded non-belligerency during Kissinger's shuttle, seemingly apart from Rabin's February declaration that an appropriate substitute to "non-belligerency" would be acceptable, the Ford administration interpreted the demand as an attempt to undermine negotiations. Simply put, the breakdown in negotiations killed the momentum towards a general peace agreement created by step-by-step diplomacy.

\footnotetext{
${ }^{8}$ Spiegel, 290.

${ }^{9}$ Summary of meeting between Thomas O'Neill and PM Rabin in Rabin's Office, written by Shalev, 4 April 1975, Ministry of Foreign Affairs - Office of the Foreign Minister [hereafter, MFA-OFM], Het, Tzadik - 6853/8, Israel State Archives [hereafter, ISA]. O’Neill would serve as Speaker of the House between 1977 and 1987.
} 
Not only was the failure of negotiations bad for the cause for peace, the Administration also recognized it opened the possibility for the resumption of war and all that went with it, including an oil embargo that would shock an already struggling economy. The overriding concern of the Ford administration during and after the reassessment period was to prevent another war in the Middle East because it would likely involve another oil embargo with little chance of a negotiated settlement. However Israeli officials stressed the problem of giving something tangible to Egypt, like land in the Sinai Peninsula, in return for political pledges from an Egyptian leader that had recently attacked Israel on Yom Kippur. Israel needed to be persuaded through economic and political incentives, rather than be pressured by them, in order for an agreement to come to fruition.

President Ford, who in his autobiography remembers being "mad as hell" because of Israeli "stalling," responded with reassessment. ${ }^{10}$ Reassessment included an immediate freeze on U.S. aid to the region and halted step-by-step diplomacy while the Administration contemplated the possibility of shelving the diplomatic method and searching for a general settlement at a Geneva conference. Neither Israel nor the United States wanted to move immediately to a general agreement; one important reason why Kissinger implemented step-by-step diplomacy was so that the U.S. could remain in control of the pace of negotiations, and prevent outside forces, like the Soviet Union, Europe, Japan, and the PLO, from clamoring for a full withdrawal to the 1967 borders. Ford and Kissinger were likely very reluctant to pursue a peace conference at Geneva given the weakened image of the U.S. during the fall of Saigon, as well as Ford's lessthan-powerful stature as an unelected president. Thus, reassessment was clearly designed to put

${ }^{10}$ Gerald R. Ford, A Time to Heal: The Autobiography of Gerald R. Ford (New York: Harper \& Row, Publishers), 247. 
pressure on Israel to pursue negotiations in such a way that invited broader peace discussions down the road.

In response, Israel launched a hasbara to make its case directly to Congress, the President, and the American people. Kissinger recalled that Ford was especially irritated when Dinitz returned to the U.S. after the failure of negotiations before Kissinger did in order to coordinate an Israeli strategy with American Jewish leadership. ${ }^{11}$ The hasbara had three main goals. First, to turn the foreign aid spigot back on; second, to eliminate the appearance of divisions between the U.S. and Israel, which could have invited an attack from Arab states; and third, to prevent the Ford administration from forming a new Middle East policy without influence from, or at least coordination with, Israel.

The hasbara relied heavily on the Israeli embassy, and especially the Israeli ambassador, Simcha Dinitz. Dinitz was in an unusually powerful position for an ambassador. As the former Director General and political adviser for Meir, Dinitz was well-informed about Israeli policy with respect to the peace process and U.S.-Israel relations. What made Dinitz's position even more powerful was the unstable Israeli political situation. Meir resigned in April 1974, a result of Israel's unpreparedness for the 1973 war. At the end of May, right after the Israel-Syria agreement, she was replaced by Yitzhak Rabin, former Ambassador to the United States. But Rabin had narrowly defeated Shimon Peres for the position of Prime Minister, and he felt obligated to included Peres in the Cabinet, which he did as Minister of Defense; additionally Yigal Allon, another important Israeli politician, was named Minister of Foreign Affairs. Sometimes referred to as the Triumvirate, Rabin, Peres, and Allon shared power in the Rabin Cabinet. The absence of a powerful, clear-cut leader in the Israeli government opened the door

\footnotetext{
${ }^{11}$ Peter Golden, Quiet Diplomat: A Biography of Max M. Fisher (New York: Cornwall Books, 1992), 316.
} 
for an experienced politician like Dinitz to exert more influence as an ambassador in Washington.

While Dinitz was the most powerful person at the Israeli embassy, he was assisted by other Israeli officials, especially David Turgemon and Zvi Rafiah. Turgemon and Rafiah were both political consultants for the Israeli embassy in Washington. Rafiah had been sent there in the summer of 1973 to "institutionalize the Congressional Liaison Office of the Embassy." He served as a liaison between the Israeli embassy and both Houses of Congress, and worked to develop positive relations with both political parties. ${ }^{12}$ Israeli officials met with an assortment of U.S. political leaders - from the White House, State Department, Defense Department, the Pentagon, and Congress, as well as influential members of the American Jewish community and reported back to the Israeli government the contents of their conversations. In doing so, the embassy helped to supply the Israeli government with crucial information about developments within the U.S. government, as well as the mood of public opinion, while also able to put out the Israeli position.

On March 24, the day after the announcement of reassessment, Turgemon met with Arthur Horton, Deputy of Robert Oakley. (Oakley worked in the NSC for Brent Scowcroft, Deputy Assistant to the President for National Security Affairs.) Horton, who asked that their conversation "be kept very private," related that Kissinger believed an agreement could have been reached, but divisions within the Israeli cabinet prevented one from happening. Peres, in particular, seemed opposed to the agreement. Moreover, Kissinger believed Israel was trying to

\footnotetext{
${ }^{12}$ Transcript of interview with Zvi Rafiah, interviewed by Paul J. P. Sandal and Laura Blackburn, Stephen F. Austin State University, accessed 9 October 2015, http://www.sfasu.edu/heritagecenter/5381.asp. Although Rafiah is portrayed as a Mossad agent in the movie "Charlie Wilson's War," as well as the book that inspired the movie, Rafiah denied the claim in his interview.
} 
play for time - to take Egypt out of the war while Israel increased its military forces. ${ }^{13}$ Horton also spoke about a potential change in US-Israeli relations and said that "Israel will have to work hard to present its point of view in front of the Congress," and not "in the direction of Senator [Charles] Percy [R-IL] but rather Senator [Daniel] Inouye [D-HI].” Percy’s support for Israel had waned. As the minority leader of the Senate subcommittee on Near Eastern Affairs, Percy had recently visited Israel and Egypt and announced his support for a comprehensive peace plan that included a homeland for Palestinians, which he would clearly state in a congressional report released on 21 April. ${ }^{14}$ Percy's position was at odds with the Israeli position that sought to prevent the creation of a Palestinian state. But Senator Inouye was viewed as someone willing to help advance the Israeli position.

Two days later, Dinitz reported to Jerusalem details of his successful meetings with numerous senators and representatives, including Senator Inouye. He met with William Broomfield [R-MI], ranking member of the House Committee on International Relations and friend of President Ford. According to Dinitz, Broomfield and other members "accepted my suggestion" that Sadat manipulated the recent negotiations - to present the Egyptian side as desiring peace - to win public support in the US, but not an agreement. ${ }^{15}$ Senator Hubert Humphrey [D-MN], known for being a strong supporter of Israel, “said we're completely okay, and this he also expressed to the New York Times - that the Congress will not move even an inch from its support of Israel." Humphrey also claimed that support for Israel in the Senate Foreign Relations Committee was strong. The meeting with Senator Inouye went well, and Inouye even

\footnotetext{
13 Turgemon to Office of Director General; 24 March 1975, MFA-OFM, Het, Tzadik - 6853/7, ISA.

14 "The Middle East," A Report by Senator Charles H. Percy to the Committee on Foreign Relations United States Senate, April 21, 1975 (Washington: U.S. Government Printing Office, 1975). In addition to Israel and Egypt, Percy also visited Iran, Kuwait, Bahrain, Qatar, Abu Dhabi, Dubai, Oman, Saudi Arabia, Lebanon, Syria, and Jordan.

${ }^{15}$ Report to Evron and Director General from Dinitz about his meeting with fourteen members of the foreign committee, 26 March 1975, MFA-OFM, Het, Tzadik - 6853/7, ISA.
} 
offered to arrange meetings between Dinitz, and "senators who are not known to be big supporters of us." Senator Richard Stone, a freshman Democrat from Florida, also offered his help and support. Stone reiterated Inouye's support saying that "Inouye told him that he will help us in the aid request of 1976." Senator Hugh Scott [R-PA] feared that liberals who supported Israel were being adversely affected by a neo-isolationism due to the Vietnam War; nevertheless, he told Dinitz that he "is supporting us and we should not fear. He will continue being our friend." 16

The Ford administration understood that the Israeli hasbara was successful in getting Israel's message out to the Congress, and at times Administration officials vented their frustrations to Israeli officials. Joseph Sisco, Undersecretary of State for Political Affairs and respected adviser of Kissinger, called Dinitz on 26 March, obviously annoyed by conversations he had that day with senators and representatives. Sisco said they all asked him the same questions, "why were the talks suspended and why don't they continue?"17 These points were central to the Israeli hasbara - establishing that there was no reason to suspend the talks, Kissinger had acted hastily, and there was no reason for them not to continue. Sisco realized that the only reasons he encountered the same line of questioning was because of the influence of Dinitz and others involved with the hasbara. He then informed Dinitz that Kissinger would not renew his mission until Israel put forth practical ideas for moving forward. Dinitz asked whether he meant procedure or substance, and Sisco replied, substance. Recognizing that the Israeli embassy was acting as a conduit for political messages, Sisco asked that his words be forwarded to Israel. ${ }^{18}$

\footnotetext{
${ }^{16}$ Ibid.

${ }^{17}$ Dinitz to Foreign Minister and Director General, 26 March 1975, MFA-OFM, Het, Tzadik - 6853/7, ISA.

${ }^{18}$ Ibid.
} 
Dinitz continued to meet with senators to advance the Israeli position. The following day he reported about his meeting with Senator John Tower [R-TX], member of the Armed Services Committee. ${ }^{19}$ Dinitz "briefed him on our position" and "made it clear that at a certain point the Egyptians stopped negotiating and turned to dictations, part of the assumption that they can manipulate the difficulties of America in different arenas to pressure Israel." Tower responded favorably and mentioned, "I always said it and I'll say it today, Israel cannot agree to any arrangement which does not include tenable and defensible borders." ${ }^{20}$

The embassy also used the legislative branch to gauge the perspective of the White House. Rafiah cabled information he obtained from a conversation with Richard Perle, assistant to Senator "Scoop" Jackson [D-WA]; Perle would go on to be an influential voice in the administrations of Ronald Reagan and George W. Bush. ${ }^{21}$ Perle and nine other senators' assistants had been briefed at the White House by Harold Saunders, Middle East analyst in the State Department. Although Saunders did not blame Israel for the breakdown in the talks, "he did leave the clear impression that Israel should have accepted the Egyptian proposal. Saunders said that the Egyptians were not unreasonable." Moreover, Saunders pointed out that Israel's reasons for rejecting the Egyptian proposal were minor compared to the potential consequences of the failure of peace talks. Perle reported that Saunders' message was well-received, and that "people taking part in the meeting felt that Israel was to blame."22

Dinitz offered his overall assessment of the situation on 28 March, based on information from White House briefings to Congress, meetings with senators and representations, and

\footnotetext{
${ }^{19}$ Dinitz to Director General and Evron, 27 March 1975, MFA-OFM, Het, Tzadik - 6853/7, ISA.

${ }^{20} \mathrm{Ibid}$.

${ }^{21}$ Rafiah to the Ministry of Foreign Affairs; 27 March

${ }^{22}$ Ibid.
} 
meetings with members of the press. ${ }^{23}$ President Ford was angry at Israel, not because Israel pursued its own national interest, but because Israel failed to appreciate the difficult position of the White House on both the domestic and foreign fronts. "All the American international affairs," wrote Dinitz, "along with huge difficulties in domestic affairs, are destabilizing his position in the U.S. at a time when he needed more than ever success in the Middle East." Ford felt Israel was ungrateful, given all the U.S. political and economic support. The Administration wanted to avoid a peace conference at Geneva because the U.S. feared it would lose control of process. Dinitz noted the strong support of Congress, but also a sense of disappointment about the failure of peace talks. Many members of Congress were concerned about a long stalemate that could lead to war, and all that came with it, including an oil embargo. Most of the criticisms coming from the Congress, however, were directed at the Administration for ending peace discussions too quickly. Dinitz believed that the Administration had started to moderate its statements both publicly and privately, not ascribing blame to anyone, because of the influence of Congress, which pressed the Administration to reaffirm its friendship with Israel in order to avoid signaling to Israel's enemies that it could be attacked. ${ }^{24}$

The assessment also commented on the importance of the hasbara. Dinitz intended to continue "our hasbara line" that centered on four main topics: an explanation of the Israeli position in the recent negotiations, support for the continuation of the U.S. process, appreciation for Kissinger and his efforts, and that talks failed "because of Egypt's rigid position and our hint that Egypt was trying to manipulate the tough situation of the U.S. to dictate conditions to Israel and the U.S. instead of negotiating. [This argument was received well by the Congress and the press.]" Thus, not only was Israel able to take advantage of the political turmoil of the U.S., it

\footnotetext{
23 "Interview with the President and Political Developments," written by Dinitz to Foreign Minister and Director General, 28 March 1975, MFA-OFM, Het, Tzadik - 6853/7, ISA.

${ }^{24}$ Ibid.
} 
also blamed Egypt for doing the very same thing. Dinitz even suggested that if Israel tried to take on President Ford and Kissinger, "We can maybe even bring about the fall of State Secretary." But then he questioned, "Would it serve our interests?" Dinitz recommended not going in that direction because the next Secretary of State might be worse for Israel. ${ }^{25}$ Either way, the pressure on Kissinger reached the point that, according to a report from Dinitz on 8 April, Kissinger offered his resignation to President Ford, who refused to accept it. ${ }^{26}$

In addition to its hasbara, Dinitz suggested Israel do something more. "I think we need to sincerely consider political maneuvers that will benefit us in the short and long term," he wrote. ${ }^{27}$ Dinitz wondered "if Egypt does not give much in return, will we be able to get anything in return from America in the field of bilateral relations as a compensation?" 28 Israeli officials continued to stress the problem of giving up something tangible, like land in the Sinai, for Arab promises to avoid attacking Israel, especially given the lack of trust. Not coincidentally, when the Sinai II agreement was actually reached in September, Israel received not only a political pledge from Egypt, but also unprecedented economic and political support from the United States.

Dinitz regularly prepped individuals for their meetings with Administration officials, like Detroit oil magnate Max Fisher. Fisher was a longtime friend of Ford, significant contributor to the Republican Party, and one of the most influential members of the American Jewish community. Fisher met several times with Ford over the course of reassessment, as well as Rabin, Allon, Peres, and Meir. ${ }^{29}$ Dinitz reported to Foreign Minister Allon, "I prepared Fisher for his meeting with the President. Fisher met the President and I received the final report. Kissinger

\footnotetext{
25 Ibid.

${ }^{26}$ Dinitz to Director General, 8 April 1975, MFA-OFM, Het, Tzadik - 6853/8, ISA.

27 "Interview with the President and Political Developments," written by Dinitz to Foreign Minister and Director General; 28 March 1975, MFA-OFM, Het, Tzadik - 6853/7, ISA.

28 Ibid.

${ }^{29}$ Peter Golden, Quiet Diplomat: A Biography of Max M. Fisher (New York: Cornwall Books, 1992$), 323$.
} 
and Scowcroft were also in the meeting. It was serious but also very friendly. The President was very serious but somber. He said a major opportunity had been missed." ${ }^{30}$ Fisher reported that Ford was angry because he feared the U.S. position in the Middle East was collapsing, and Kissinger was obviously upset and rarely talked. After the meeting, Fisher said the Secretary "looked as if the whole world had turned around against him." 31

On 7 April, Dinitz talked with Fisher for an hour on a public phone. During their conversation, Dinitz “advised Fisher not to speak only with Kissinger, but also have a conversation with the President ... Then I reiterated the main points he should raise in front of the President, and to uproot the thought that he was misled by us. Fisher promised he would." ${ }^{\prime 32}$ Dinitz and Fisher demonstrated that, at least during the reassessment period, the state of Israel worked in close coordination with American Jews. Therefore, discussions about the influence of the pro-Israel lobby in the United States should consider the involvement of the state of Israel in shaping lobbying efforts.

The embassy also gathered information about the ongoing reassessment. On 30 March, Dinitz sent word that, based on information from "a very reliable source," that the Pentagon was in the process of creating a report about the balance of power in the Middle East, specifically designed to "justify an immediate halt to all aid to Israel." ${ }^{33}$ Dinitz noted, however, the report was only at the working level and in no way represented a decision. ${ }^{34}$

Two days later, Turgemon followed-up with a more detailed report of the reassessment, based on his meeting with Phillip Stoddard, Deputy Head of the Middle East and South Asia in

\footnotetext{
${ }^{30}$ Dinitz to Foreign Minister and Director General, 28 March 1975, MFA-OFM, Het, Tzadik - 6853/7, ISA. For the U.S. perspective of the meeting, Memorandum of Conversation, Ford, Kissinger, Scowcroft, and Max Fisher, March 27, 1975, Memcons, Box 10, March 27, 1975 - Ford, Kissinger, Max Fisher, Gerald R. Ford Library.

${ }^{31}$ Ibid.

${ }^{32}$ Dinitz to Director General, 7 April 1975, MFA-OFM, Het, Tzadik - 6853/8, ISA.

${ }^{33}$ Dinitz to Minister of Defense and Prime Minister and Head of IDF Intelligence, 30 March 1975, MFA-OFM, Het, Tzadik - 6853/7, ISA.

${ }^{34}$ Ibid.
} 
the State Department. From their conversation, Turgemon reported that those responsible for writing papers about the reassessment, from the working level of the State Department and other branches of the administration, were to hand in their papers by 5 April. That would be followed by a period of analyzing and summarizing the material, and then conclusions and recommendations. The Administration deliberately made a short deadline because they did not want too much time to pass without action. ${ }^{35}$

According to his report, Turgemon spent more time discussing the broader picture with Stoddard, rather than the details of reassessment. The reassessment, Stoddard claimed, had two strategic goals - first, "To show Israel that it should have hopped on the train while it was still in the station, and not try to catch it after it left." When given another chance, Israel should "climb on the train at the station." Second, to reevaluate U.S. policy in the Middle East in general, and each country specifically - topics such as weapons sales to Iran and Saudi Arabia, the positions and policies of each country, as well as potential pressures that could influence Syrian President Hafez al-Asad and Sadat, the policy of the USSR, and what America would do if another war erupted in the Middle East. Stoddard said the chief goal of the U.S. policy was to prevent war because "the US government does not see much chance to solve the conflict." 36

While the reassessment proceeded at the working level, Kissinger met with influential figures in the American Jewish community. The records of their discussions speak to the inner turmoil Kissinger felt as an American Jew, and as U.S. Secretary of State. The records also show that several American Jews were turned off by Kissinger when he continually highlighted his Jewishness.

\footnotetext{
${ }^{35}$ Turgemon to the Center and Intelligence of the Foreign Office, 1 April 1975, MFA-OFM, Het, Tzadik - 6853/8, ISA. Syrian President Asad had negotiated a disengagement agreement the previous May, and negotiations with Syria loomed after a potential agreement between Israel and Egypt.

${ }^{36}$ Ibid.
} 
While trying to explain the Administration's position, Kissinger vented his frustrations to four prominent Jewish intellectuals on 30 March - Elie Weisel, Hans Moganthou, Max Kempleman, and John Stoessinger. ${ }^{37}$ "Kissinger opened with horrid depictions of Israeli intransigence," according to a report written by Mordechai Gizat, Director General for the Prime Minister, and twice complained that in 24 meetings Israel never once demanded nonbelligerency. He claimed that Israel was making a "historic disaster" because the U.S. could no longer help Israel as it had in the past, and anti-Semitism was rising in the United States. Kissinger said that the existence of Israel was in jeopardy. Weisel, who survived Auscwitz, was especially disturbed by Kissinger's portrayal of the situation. He asked the Secretary if he, as a Jew and historian, had trouble sleeping at night. Kissinger answered that he did not sleep well. But Kissinger reminded the group, "After all, I am Jewish. As long as I am Secretary of State there never will be another Czechoslovakia." 38

The question still remained about how to move forward in light of the recent breakdown of talks. Kissinger indicated that Geneva was a real option, and that Israel could not expect full U.S. support. He asked if American Jews would accept UN Resolution 242 as the basis of negotiations. "Weisel said that if the government of Israel will agree to it, so will American Jews. The most important thing is Jerusalem - it must stay in the hands of Israel. Kissinger said, okay." 39

While U.S. officials contemplated a new policy, Dinitz received a message from Ephraim Evron, Deputy Director General of the Foreign Ministry, suggesting that Israel needed to stop stalling and formulate a more concrete plan. According to Evron, "We want to make clear that

\footnotetext{
${ }^{37}$ Report of Mordechai Gizat to the Prime Minister, 31 March 1975, MFA-OFM, Het, Tzadik - 6853/7, ISA.

${ }^{38}$ Ibid. Kissinger was referencing the March 1938 agreement between Western leaders and Nazi Germany, which conceded the Sudetenland of Czechoslovakia to Nazi Germany in return for Hitler's pledge to not take any more land. Nazi Germany subsequently annexed all of Czechoslovakia in March 1939.

${ }^{39}$ Ibid.
} 
we are not negotiating to just buy time, and that this time [italics added] our goal is to make progress." 40 The message echoed Sisco's earlier request to have Israel create substantive peace plans. Step-by-step diplomacy had intentionally aimed to buy time to allow Israel to prepare to return the occupied territories. Israeli policy was specifically designed to not create a policy, and use the passage of time to increase its military position. Reassessment was meant to force Israeli officials to begin pursuing a more detailed agenda, but the Israeli domestic situation was too divided to advance a coherent plan.

Kissinger continued to complain behind the scenes to influential members of the American Jewish community about the hasbara. He met with Fisher and Rabbi Israel Miller, Chairman of the Conference of Presidents of Major Jewish Organizations, and again bemoaned how Israel had misled the Administration and in the process damaged U.S. prestige. Miller grew irritated when Kissinger claimed that, to a certain extent, he was happy because as a Jewish Secretary of State, the heavy responsibility was off his shoulders. Rabbi Miller reminded Kissinger that there is responsibility that sits on the shoulders of every Secretary of State, and "he as a Jew should see this as an honor and not just as a burden." Miller then explained that, as a leader of the Jewish community, he felt he was "sitting on a volcano," trying to prevent outbursts from prominent Jews directed at the President and Secretary. Kissinger asked what he could do to help, and Miller said to "cool it." Additionally, Kissinger agreed to have Sisco brief the Conference of Presidents about the Administration's policy. ${ }^{41}$ Later in April, Kissinger was reportedly bitter and angry when talking with Nahum Goldman, founder and President of the

\footnotetext{
${ }^{40}$ Evron to Dinitz; 31 March 1975, MFA-OFM, Het, Tzadik - 6853/7, ISA.

${ }^{41}$ Arad to Director General, Evron, and Dafney, 1 April 1975, MFA-OFM, Het, Tzadik - 6853/8, ISA.
} 
World Jewish Congress. Kissinger accused Israel of being shortsighted, and that "Israel lost a rare opportunity to have negotiations that would have led to taking Egypt out of the war."42

The leaders of the major Jewish organizations in the United States, obviously perturbed by the Administration and especially Kissinger, held an informal meeting at Fisher's flat in New York in early April. The general feeling of the Jewish leadership was that the Administration was increasingly hard to defend (especially to "friends and activists" involved with Jewish organizations) because of public statements suggesting Israel was to blame for the failure of negotiations. The participants agreed that Kissinger needed to be talked to in a "straightforward" manner, and be "brought back down to Earth." Fisher was very firm about the need to keep a Jewish front and not publicly criticize Israel, but rather voice criticisms privately to Israeli leadership. Fisher also believed that "a responsible Israeli leadership should consider the influential position and perspective of the American Jewish leadership." ${ }^{43}$

Right around the same time, Kissinger held a stormy meeting with an angry Arthur Goldberg, former Supreme Court Justice and ambassador to the UN who helped draft UN Resolution $242 .{ }^{44}$ Goldberg was especially irritated by the New York Times report about Kissinger's meeting with the "Eastern Political Establishment," which included Cyrus Vance, George Ball, McGeorge Bundy, and others not known for being strong supporters of Israeli policy. According to Dinitz, based on his phone conversation with Goldberg, Kissinger began the meeting with Goldberg by claiming

the entire purpose of his policy and as a Jew are to help Israel and to make sure nothing bad will happen to her. Goldberg stopped him and told him, don't tell me that shit. Are you forgetting who you are talking to? Do you think you are talking

\footnotetext{
${ }^{42}$ Arad to Director General and Intelligence of Foreign of Foreign Office, 28 April 1975, MFA-OFM, Het, Tzadik 6853/9, ISA.

${ }^{43}$ Arad to Evron, Irgov, and the Intelligence of the Foreign Office, 2 April 1975, MFA-OFM, Het, Tzadik - 6853/8, ISA.

${ }^{44}$ Dinitz to Director General, 2 April 1975, MFA-OFM, Het, Tzadik - 6853/8, ISA.
} 
to the press or Jewish leadership? You are talking to someone who was in a Cabinet. Representative in the UN and member of the Supreme Court, in a higher rank than you are. I am a proud Jew and I am not interested to know what you are doing as a Jew and not doing as a Jew. I am talking to you from American interests. $^{45}$

Kissinger, reportedly embarrassed, apologized and said he would rather resign than have an antiIsrael policy. Goldberg scolded him again and said, "If you want to resign, then resign. America will continue without you. I resigned from the Supreme Court and America continued to exist. America is big enough and strong enough and does not depend on one person." 46

Dinitz continued to coordinate with Jerusalem about using members of the American Jewish community to meet with U.S. officials. On 7 April, the Director General inquired of Dinitiz, "Did you activate, maybe you have already done it, Dave Ginsberg to meet Cyrus Vance and McGeorge Bundy; Ted Sonnenfeld to see Averell Harriman and Dean Rusk. These were the people in the group with whom the State Secretary met. And also Dave Fortis to see McNamara?"47 Dinitz replied, “I'm in contact with Dave Ginsberg and I'm activating him. He's also one of the main people giving us information about the group Kissinger is meeting."

Kissinger believed that Israel was trying to use Congress to influence policy and attack the Administration. According to an unnamed source, Kissinger informed Republican and Democratic legislators on 31 March that "the intention of Israel is to cause damage to the

${ }^{45}$ Ibid.

${ }^{46}$ Ibid.

${ }^{47}$ Director General to Dinitz, 7 April 1975, MFA-OFM, Het, Tzadik - 6853/8, ISA. David Ginsberg, according to the New York Times, successfully represented Kissinger in his battle to keep private transcripts of phone conversations while Secretary of State and National Security Adviser for Richard Nixon (William Grimes, "David Ginsberg, Longtime Washington Insider, Dies at 98", New York Times, May 25, 2010, accessed 1/15/16, http://www.nytimes.com/2010/05/25/us/25ginsburg.html? r $=0$ ). Cyrus Vance served as Deputy Defense Secretary under Lyndon Johnson, and would become Jimmy Carter's Secretary of State in 1977. McGeorge Bundy served as National Security Adviser for Presidents Kennedy and Johnson. W. Averell Harriman was a longtime politician active in the presidential administrations of Franklin Roosevelt and Harry Truman; after losing the Democratic nomination for President to Adlai Stevenson in 1952 and 1956, Harriman was an important diplomat for the Johnson and Kennedy administrations. Dean Rusk served as Secretary of State for both Johnson and Kennedy. The Sonnenfeld referred to in the message was probably Helmut Sonnenfeld, a close adviser to Kissinger, whom Kissinger speaks fondly of in his third memoir, Years of Renewal (New York: Simon \& Schuster, 1999).

${ }^{48}$ Dinitz to Director General, 7 April 1975, MFA-OFM, Het, Tzadik - 6853/8, ISA. 
Administration, and it is doing it through an effort to influence the Congress directly while bypassing the White House and State Department, and while taking advantage of the election year." Kissinger felt that Israel was trying to make the U.S. look like a "paper tiger," and that the U.S. "needs to develop a new foreign policy, and to take a middle ground position with all the parameters of 242." According to the report, no one in the meeting challenged his statements or disagreed with the need to develop a new strategy. ${ }^{49}$ Although it is unknown who took part in the meeting, such a message reflects a growing uneasiness on the part of some congressmen to take on the Administration over U.S. foreign policy in the Middle East. When Tip O'Neill met with Prime Minister Rabin in early April, he reminded Rabin that Israel "could not have a finer friend in Congress than me." However he cautioned Rabin, "Do not underestimate Kissinger with the Congress. He mesmerizes the Congress when he performs in front of them." O'Neill recognized the challenging circumstances for Israel - "I appreciate the power of the Jewish lobby, but the Jewish lobby never stood in front of a crisis like this one." ${ }^{50}$

Kissinger continued his close contact with influential American Jews to vent his frustrations and search for a way to restart step-by-step diplomacy. Dinitz reported a long conversation between Kissinger and Leonard Garment, who briefly served as White House Counsel for Nixon during his last few months as President. Garment, like Fisher, reported that Kissinger was "a broken person", and that in all his years with Kissinger he could not recall Kissinger in such "a difficult personal and mental state." Kissinger referred to Rabin, Allon, Dinitz, and members of the Israeli negotiating team as "his brothers." [He noticeably failed to specifically mention Peres.] Kissinger feared that because Israel did not go along with step-bystep diplomacy both the U.S. and Israel would lose all control over negotiations. Therefore, he

\footnotetext{
${ }^{49}$ Bentzer to Director General and Evron, 3 April 1975, MFA-OFM, Het, Tzadik - 6853/8, ISA.

${ }^{50}$ Summary of meeting between Thomas O’Neill and PM Rabin in Rabin's Office, written by Shalev, 4 April 1975, MFA-OFM, Het, Tzadik - 6853/8, ISA.
} 
believed the best thing to do was to restart the American initiative and avoid Geneva (that is, a multinational Middle East peace conference). He felt it was in the best interest of both states. Kissinger told Garment, "As a Jew he has only one goal and that is the safety and integrity of Israel. As an American State Secretary he has believed and will believe that the safety and integrity are basic principles of American policy." Garment reminded Dinitz that "with all of our rightful criticism of Kissinger, one needs to remember he is paranoid and does not control himself. But he is also, above all, the best friend Israel has ever had in the Administration." When Kissinger met with Dinitz on 7 April, he asked to speak privately for twenty minutes before the meeting began. Kissinger was obviously angry. He referenced the Israeli hasbara against him and threatened to turn the tables and "release a white paper about the Israeli policy and its behavior." Specifically, Kissinger wanted to release information about the 24 times Israel was told by top U.S. officials that non-belligerency was off the table. But Dinitz shot back that the reason for the entire blow-up was Kissinger - he could have acted differently when negotiations were suspended, but instead chose to confront Israel. Kissinger admitted that he overreacted, but it was a reflection of the deep pain he felt. And since that time, he had been portrayed by the Jewish and Israeli media as an enemy of Israel. He reminded Dinitz, "I treated you with more trust than most of my colleagues at work. I showed you messages, telegrams, and wires from the Soviet Union and Egypt." He told Dinitz that he had offered his resignation to Ford, but that Ford refused to accept it. "I will not agree being Secretary of State," said Kissinger, "when I see how things are going and what Israel is bringing on herself." According to Dinitz, Kissinger "said in a crying voice, I was a Jew before I was an American and now you are making me the scapegoat!" Clearly too close to the situation as a U.S. Secretary of State, Kissinger informed Dinitz that "of all the countries in the world, Israel is to him most important

${ }^{51}$ Dinitz to Director General, 6 April 1975, MFA-OFM, Het, Tzadik - 6853/8, ISA. 
and added, I am part of the Jewish nation and have no closer people than the leaders of Israel and their ambassador here." 52

Dinitz continued to prepare American Jews for meetings with the Administration. He informed the Director General on 9 April that he had prepared Garment and Fisher for their meeting with Kissinger, and that he prepared Fisher for his meeting with Ford. Dinitz also reported that the two had met with White House Chief of Staff Donald Rumsfeld, and told him to have the President make a public statement indicating that the reassessment was not directed against Israel. The two also reported talking with Senator Jacob Javits (R-NY), and that Javits also agreed to talk with Ford about releasing a public statement to that effect. ${ }^{53}$ According to an assistant of Javits who asked not to be quoted, although the senator was a supporter of Kissinger he was "very annoyed by the Secretary blaming Israel, that he is creating such a big kerfuffle, and that he is behaving like a small child who is unhappy because people are not responding to his wishes. $" 54$ Dinitz again contacted Fisher on 23 April to ask him to press Ford about the frozen shipments of aid. Although Fisher suggested that he cannot call on the President specifically about that matter, he would find a way to reach him. Dinitz and Fisher agreed to coordinate and plan for the meeting when Fisher returned to Washington the following week. ${ }^{55}$

The Israeli hasbara was clearly effective in getting the Israeli message out for U.S. public consumption. Dinitz reported being in a "maximum hasbara effort and there are already practical results." Perhaps chief among them was rattling Kissinger, who complained that Israel was sending lecturers all over the U.S., mostly former generals and all hardliners. Kissinger

\footnotetext{
${ }^{52}$ Dinitz to Director General, 8 April 1975, MFA-OFM, Het, Tzadik - 6853/8, ISA.

${ }^{53}$ Dinitz to the Director General, 9 April 1975, MFA-OFM, Het, Tzadik - 6853/8, ISA.

${ }^{54}$ Rafiah to Dafney, 10 April 1975, MFA-OFM, Het, Tzadik - 6853/8, ISA.

${ }^{55}$ Dinitz to Director General and Foreign Minister, 23 April 1975, MFA-OFM, Het, Tzadik - 6853/9, ISA. Rumsfeld became Secretary of Defense in the Ford administration in November 1975, where he served until the end of Ford's presidency.
} 
reportedly complained that Dinitz was "a determined hardliner and he is doing a hasbara campaign in Congress, the press, and amongst the American Jews." ${ }^{, 56}$ Dinitz met for an hourand-a-half with James Reston of the New York Times, who told Dinitz that Israel's arguments were being well-received in public opinion, namely, that the Administration was responsible for sour relations with Israel and it was up to the Administration to make it right. Reston "said the friendship for Israel in the U.S. is very deep and extensive." ${ }^{, 57}$ The embassy also reported that NBC had sent out a questionnaire about the U.S.-Israel relationship, and that the results were to be published on radio and television before President Ford's speech that night. It seemed to the embassy that NBC was "considering the opportunity of making a television program about the hasbara attack in the U.S. - How many lectures were sent, etc. We will inform when we know more." 58

Israeli officials continued to meet with senators and representatives in order to generate more support for Israel. Senator Bumpers, who defeated William Fulbright in the Democratic primary in Arkansas, emphasized his support for Israel in a meeting with Abba Eban, longtime Israeli politician and diplomat. ${ }^{59}$ So did Senator Robert Griffin (R-MI), friend of President Ford and Max Fisher, and member of Foreign Relations Committee. Griffin reminded Eban "that the tendency of the Congress is to work independently in the issue of foreign affairs", which complicated the situation for Kissinger. ${ }^{60}$ When Eban met with Senator Stuart Symington (D-

\footnotetext{
${ }^{56}$ Dinitz to Director General, 2 April 1975, MFA-OFM, Het, Tzadik - 6853/8, ISA.

${ }^{57}$ Dinitz to Director General, 7 April 1975, MFA-OFM, Het, Tzadik - 6853/8, ISA.

${ }^{58}$ Rappaport to the Press and Hasbara Department of the Foreign Office, 10 April 1975, MFA-OFM, Het, Tzadik $6853 / 8$, ISA.

${ }^{59}$ Rafiah to the Intelligence of the Ministry, Eban meeting with Senator Bumpers, 17 April 1975, MFA-OFM, Het, Tzadik - 6853/9, ISA.

${ }^{60}$ Rafiah to the Intelligence of the Ministry, Eban meeting with Senator Griffin, 17 April 1975, MFA-OFM, Het, Tzadik - 6853/9, ISA.
} 
MO), Symington said that even though he was fond of Kissinger, the Secretary should not have reacted the way he did. ${ }^{61}$

The meeting with Symington revealed that while Israel hoped to use the U.S. Congress to advance its agenda, the reverse was true as well. Eban raised the question about a delay on deliveries of the F-15 Eagle fighter jets, which were made by McDonnell Douglass in Symington's home state, Missouri. Although President Ford had ordered a freeze on arms sales and shipments, the order had been placed before reassessment with delivery to happen at some point in the future. According to the report, "Symington called immediately one of the bosses at McDonnell who told the senator the following - Israel is supposed to get 25 planes [and possibly 50] at the rate of 2 to 3 a month beginning in mid-1976." However, the official at McDonnell confirmed that there were delays. "Symington responded with anger" and said that if they did not deal with the delay immediately Israel would not get the planes for many years. After that, Symington wanted to speak with Sisco about the same issue but could not reach him, and then promised to report to Eban about his talk with Sisco. At that point, "the senator started to talk about the great virtues of the planes." ${ }^{\circ 2}$

Dinitz recognized that Israel had to walk a fine line. While trying to communicate its message through its hasbara campaign, Israeli officials had to be careful to not be seen as attacking the President. Tip O'Neill told Dinitz that he had "the impression that Israel and the Jewish lobby want to have a direct fight with the President and Secretary within the Congress and using the Congress." According to Dinitz, "O'Neill advised us not to do this terrible mistake. ${ }^{\prime 63} \mathrm{O}$ 'Neill recognized that Congress and the President were divided by Vietnam, and

\footnotetext{
${ }^{61}$ Rafiah to the Office of the Director General, Eban meeting with Stuart Symington, 17 April 1975, MFA-OFM, Het, Tzadik - 6853/9, ISA.

62 Ibid.

${ }^{63}$ Dinitz to Director General, 23 April 1975, MFA-OFM, Het, Tzadik - 6853/9, ISA.
} 
that when the 1976 election came around that O'Neill, a Democrat, would fight against any Republican. But until then, O’Neill warned against taking on the President. Dinitz assured him that Israel had no intention of taking on the President or Secretary inside or outside of Congress. ${ }^{64}$

Kissinger continued to voice his frustrations about the Israeli hasbara. In a secret meeting with Foreign Minister Allon and other Israeli and U.S. officials, Kissinger told the meeting that when any country disagrees with U.S. policy it should handle the issue through diplomatic channels and not launch a public relations campaign. If Israel continued to try to undermine the Ford administration, Kissinger again threatened to release a fact sheet about Sinai II discussions and U.S.-Israel relations. ${ }^{65}$ However just over a week later, Lawrence Eagleburger, Executive Secretary to the Secretary of State and future Secretary of State for George H. W. Bush, told an Israeli official to ignore Kissinger's threats about a white paper. ${ }^{66}$

Dinitz reported back to Jerusalem a humorous story about how one senator confused the Israeli line when talking with Kissinger. Senator Richard Stone, a Jewish Democrat from Florida, called Dinitz on 22 April and told the ambassador that he and six other new senators planned to meet with Kissinger at the State Department. Stone asked if he should bring up any certain topics with Kissinger, and Dinitz responded that he should ask about delays pertaining to shipments of the F-15 fighter jets, along with other topics. After the meeting, Stone told Dinitz he had made a slight error. Dinitz had suggested to ask Kissinger about the visit of an Air Force delegation to talk about the F-15s; Stone mistakenly asked Kissinger about training Israeli pilots to fly F-15s. Kissinger, naturally, had no idea what Stone was talking about. However he did indicate, like

\footnotetext{
${ }^{64}$ Ibid.

${ }^{65}$ Shalev to Director General, 22 April 1975, MFA-OFM, Het, Tzadik - 6853/9, ISA.

${ }^{66}$ Evron to Minister of Foreign Affairs, 2 May 1975, Ministry of Foreign Affairs - Office of the CEO [hereafter, MFA-CEO], Het, Tzadik - 6813/11, ISA.
} 
Symington, that there were production delays of the F-15s and Israel would not start receiving them until the following year. Nevertheless, Stone managed to invent a topic for discussion with the Secretary of State, based on his misunderstanding of instructions from the Israeli Ambassador. Ionically, given Stone's misstep, Dinitz reported that "Stone told me that he does not believe a word of the Secretary." ${ }^{67}$

The Israeli embassy continued to quietly collect information about the Ford administration. Dinitz reported that there were indications that Ford did not intend to run for President in 1976, and he therefore felt free from domestic pressures in order to pursue the national interest in foreign policy. According to Dinitz, rumors had swirled for some time that Ford would not run in 1976, primarily because of the poor U.S. economy and health concerns about his wife, Betty. Dinitz rightly pointed out that a decision had not been made, but he also thought that Ford was starting to think more independently (that is, independent of Kissinger) on matters relating to foreign relations. ${ }^{68}$

Similar to his report of 28 March, Dinitz sent a periodic assessment of happenings in the U.S. to Foreign Minister Allon on 28 April. He noted that both Houses of Congress maintained their traditional support. Additionally, "liberals and isolationists" were articulating the differences between Southeast Asia and the Middle East, even as Saigon was falling. Nevertheless, indications were that Congress would not support a large aid request for Israel. According to Dinitz, "This development is not due to the suspension of talks, but rather a result of the financial crisis and by the fact that the Congress is more meticulous and critical of expenses, and foreign aid in particular." At the same time, even pro-Israel congressional members voiced their concerns about stalemate and the suspension of talks because the region

\footnotetext{
${ }^{67}$ Dinitz to Evron, 24 April 1975, MFA-OFM, Het, Tzadik - 6853/9, ISA.

${ }^{68}$ Dinitz to Director General, 24 April 1975, MFA-OFM, Het, Tzadik - 6853/9, ISA.
} 
could erupt into war and even further erode the U.S. position domestically and internationally. Dinitz also reminded Allon that even with strong support from Congress, according to the U.S. Constitution the President determines and implements foreign policy. However, he added that "Congress has helped in the past and could help in the future." ${ }^{\circ 9}$

The primary concern for Dinitz, even more than misunderstandings and sour relations between the U.S. and Israel, was the formulation of a new U.S. policy less favorable to Israel. Dinitz no doubt expected foreign aid to resume, especially with strong support for the Israeli position in the U.S. Congress. But if the Ford administration created a new policy, one that was not based on step-by-step diplomacy or a deliberate avoidance of the core issues at the heart of the peace process, then Israel would inevitably be in a disadvantageous position. He noted that even with influence in the U.S. "public sphere" specifically related to its hasbara, Israel needed to assert itself into the "political sphere." In particular, Israel needed to decide if it wished to renew the U.S. initiative and enter into a separate agreement with Egypt, or go to Geneva and try to negotiate a general agreement that included all participants in the conflict. Dinitz mentioned that he favored an interim agreement, but that with each passing day that step seemed less likely, and a general agreement more likely. Therefore Israel needed to develop a dialogue about a separate agreement with Egypt, and push the Administration to advance bilateral relations between the U.S. and Israel in return for an Israeli withdrawal and political declarations from Egypt. $^{70}$

Increasingly, however, Dinitz feared that a Middle East settlement seemed to be moving towards the 1967 borders with an independent Palestinian state, combined with demilitarized zones and guarantees of safety. Kissinger, as Dinitz reminded Allon, had told Israel a few times

\footnotetext{
${ }^{69}$ Dinitz to Minister of Foreign Affairs, Periodical Assessment of the Israeli Ambassador in Washington, 28 April 1975, MFA-OFM, Het, Tzadik - 6853/9, ISA.

${ }^{70} \mathrm{Ibid}$.
} 
that such a scenario was the beginning of the end for the state of Israel. And without greater Israeli assertiveness in the political sphere, "such a maneuver will receive not only an international consensus but will also receive wide support in the US. [I dare to say there will be a few Jews, and even important ones, that will agree to such a formula.]"71

Therefore, Dinitz recommended that Israel abandon its policy of intentionally buying time and communicate "concrete" suggestions to the Administration. According to Dinitz, "I do feel that the end of buying time is getting near and what we wanted to do by delays is no longer preventable, and what we succeeded in delaying by shutting up may evolve into a policy." Basically, Dinitz feared that the Ford administration was in the process of developing a new strategy for the peace process, and such a strategy - and ultimately, policy - would be created with or without Israeli participation. Dinitz finished his lengthy assessment with a reminder "One thing that we cannot do anymore is that we cannot avoid discussing the core issues. We cannot believe by not talking to the Americans we can avoid the development of a process. The policy and the process will be created with us or without us. I believe it will be better with us." 72 The following day Dinitz sent word about a plan to use Congress to challenge the Administration with enough force to influence U.S. foreign policy. "After a long conversation I had with Congress members and consultation I had with Morris Amitay [Executive Director of the American Israel Public Affairs Committee, or AIPAC, the most powerful pro-Israel lobbying organization in Washington] and Rafiah, I have raised the thought about trying to organize a letter from the senators to the President. Evaluation of experts and from first approaches to senators' assistants, it is believed that it is possible reach approximately 70 signatures on the letter." Dinitz even included a draft of the letter. He mentioned the advantages of such a letter,

\footnotetext{
${ }^{71}$ Ibid. The brackets are in the original document.

${ }^{72}$ Ibid.
} 
with that many signatures, were obvious. However in all likelihood the letter would be seen as a direct attack on the Administration, "even with the careful phrasing of the letter and the gentle tone." Therefore Dinitz recommended that "the embassy of Israel and the government of Israel will not be related to this letter in anyway whatsoever," meaning, Israeli manipulation of U.S. politics needed to be kept from public knowledge. ${ }^{73}$ The letter gradually evolved into one of the strongest congressional challenges to U.S. foreign policy in the Middle East up to that time, as well as efforts to negotiate peace in the region.

While attending a bar mitzvah at Dinitz's house on 26 April, Kissinger warned against personalizing the conflict between the U.S. and Israel and attacking himself or the President. Kissinger mentioned that he and his assistants did not agree with the Israeli position that Egypt had been rigid in negotiations, and he suggested that Israeli officials like Dinitz consider why good friends of Israel, like Ford, [Vice President Nelson] Rockefeller, Kissinger, Nancy Kissinger, General Scowcroft, and Eagleburger, changed their positions to negative after the March discussions. The Secretary pointed out that Prime Minister Rabin was mistaken if he thought he could repeat "the 1971 tricks" - when Rabin was Ambassador to the U.S. - and Israel managed to abort the plans of Jarring, Rogers, and Sisco. Kissinger admitted that in 1971 he helped Israel thwart those plans and initiatives. "But today the situation is different," reported Evron. "Kissinger is now the Secretary of State and consultant to the President, and things have changed in the international arena." Kissinger also warned that Dinitz was mistaken in assessing the Israeli influence in Congress. "There are quite a few powerful congressmen and senators who like to say positive things to the Ambassador," Kissinger said, but in discussions with the State Secretary they said other things. ${ }^{74}$

\footnotetext{
${ }^{73}$ Dinitz to Director General, 29 April 1975, MFA-OFM, Het, Tzadik - 6853/9, ISA.

${ }^{74}$ Evron to Minister of Foreign Affairs, 2 May 1975, MFA-CEO, Het, Tzadik - 6813/11, ISA.
} 
Robert Oakley revealed to Turgemon that the Administration felt handcuffed by the fallout from the Vietnam War, anti-Administration domestic politics, and congressional involvement in foreign affairs influenced by pro-Israel lobbying. Nevertheless, the Administration needed movement towards peace. He told Turgemon that "for the past 18 months Israel had consistently asked for military and economic aid and no pressure from the US so that Israel could enter into peace negotiations. Then Oakley said, look where it has gotten us." Oakley claimed that the Administration was finding it difficult to consider new initiatives in the Middle East "due to the domestic embarrassment of the Watergate affair and the tragedy of Vietnam." Moreover, relations with the Congress were becoming worse every day and Oakley bemoaned the absence of leadership within the Congress. The midterm elections in 1974, shortly after Nixon resigned the Presidency, brought many new senators and representatives to Washington, which also resulted in the old leadership losing its strength and position. Due to that turnover and the absence of leadership, the Administration found it hard to "communicate with the Congress and to influence it." 75

Israel continued to monitor the public mood in the U.S. and note the importance of domestic factors for U.S. foreign policy. A report written by Joseph Ben-Aharon to Prime Minister Rabin on 18 May explained that the situation in the Middle East had been "swallowed" by the fall of Saigon and the end of the Vietnam War. ${ }^{76}$ In trying to better his image, President Ford requested aid to assist refugees, but Congress denied the budget request. Given the economic troubles in the U.S. and increasing levels of unemployment, Congress felt that the

\footnotetext{
75 Turgemon to the Center for Political Research and Middle East Department, 5 May 1975, MFA-CEO, Het, Tzadik $-6813 / 11$, ISA.

${ }^{76}$ Joseph Ben-Aharon to Prime Minister, 18 May 1975, MFA-CEO, Het, Tzadik - 6813/11, ISA.
} 
average U.S. citizen would not support aid to refugees of an unpopular war during an economic crisis. $^{77}$

In Ben-Aharon's report, which analyzed U.S. public opinion on Israel, he mentioned that the fall of Saigon actually allowed the Administration to focus its efforts on other foreign policy issues. However, according to Ben-Aharon, "Israel needs to convince the American public that it will fight its own wars and all it needs is military support. The normal citizen in America will accept American aid to Israel as long as he feels Israel is the underdog against Arab oil and the Russians, but nevertheless tries to reach peace." 78 Moreover, there appeared to be "no change in the infrastructure of support for Israel in the non-Jewish American public.” The report claimed that two famous (and unfortunately unnamed) professors at Harvard "who are calling for more 'balanced' policy in the Middle East have regrettably admitted to me that public support is almost naught."79 However, the report warned about a "rise in Arab and pro-Arab activity, especially on campuses" and that Arab propaganda had become more "sophisticated." The economic recession had forced some private universities to search for financial support, which attracted oil money from Arab states that asked in return to teach more "about the Arab and Muslim world." Therefore, the report spoke to the "need to strengthen the Jewish and pro-Israel elements on campuses, and the need for general renovation of the Hillel system in the campuses." $" 80$

While Congress continued to express its support for Israel, behind the scenes rumors circulated that such support was starting to waver. In the opinion of Samuel H. Goldberg, Deputy

\footnotetext{
77 Ibid.

${ }^{78}$ Ibid. Michelle Mart has written an impressive study about how Americans came to view Israel as an ally during the early years of the Cold War. Importantly, U.S. popular opinion came to regard Israelis as the "gutsy underdog", which the Israeli report from May 1975 suggested that Israel continue to emphasize. Michelle Mart, Eye on Israel: How America Came to View Israel as an Ally (Albany: State University of New York Press, 2006).

${ }^{79}$ Ibid. Although unnamed, the report likely referenced Stanley Hoffmann and someone else, perhaps Kissinger.

${ }^{80}$ Ibid.
} 
Assistant Secretary for Congressional Relations in the State Department, the Vietnam War and Watergate affair had created a "certain tiredness in Congress," which contributed to growing support for a more balanced U.S. policy in the Middle East in which the U.S. would not tilt towards either Israel or the Arabs. In his estimation, support for a balanced policy had risen after the 1973 war from $2 \%$ to $10 \%$. In addition to Vietnam and Watergate, Goldberg also noted that the intense pressure on senators and representatives to advance a pro-Israel agenda was starting to create some disillusionment. According to Goldberg, "One of the problems is many congress members have this complication of feeling like captives caged by the Jewish lobby." Specifically, Goldberg said that "Senator Percy is generally a friend of Israel and Goldberg considers his recent statements as part of his attempt to get out of the captivity of the Jewish lobby." 81

But Dinitz continued to report strong congressional support for Israel. According to Senator Sam Nunn (D-GA) and Representative Elliot Levitas (D-GA), support for Israel after the fall of Vietnam was more "concrete and assured." The congressmen saw no similarity between Israel and Vietnam, and Levitas claimed that if "Israel was not included in the recent foreign aid bill, only 60 of 435 would have voted for it." While the situation in Southeast Asia had convinced some senators and representatives to reduce foreign aid, many had determined "to enlarge the defense budget to signal to the international community that the U.S. is not disarming itself." 82 Senator Richard Schweiker (R-PA) claimed that there was "no decline in U.S. support in Congress for Israel" and that Senator Percy was "a lone case." Schweiker admitted that the

\footnotetext{
${ }^{81}$ Bentzer to Dafney, 19 May 1975, MFA-CEO, Het, Tzadik - 6813/11, ISA.

${ }^{82}$ Dinitz to Director General and Evron, 21 May 1975, MFA-CEO, Het, Tzadik - 6813/11, ISA.
} 
poor economic situation in the U.S. influenced "congressional members' attitudes to foreign aid, but that aid to Israel will continue." $\$ 3$

The letter proposed by Dinitz in late April finally came into play. On 19 May, Rafiah sent word that 56 senators had agreed to sign the letter, and the following day he reported that the number had jumped to $72 .{ }^{84}$ On 21 May, Rafiah communicated that 75 senators had agreed to sign the letter and that a press conference would be scheduled the next day at 11:00am ${ }^{85}$ Finally, on 22 May a letter with 76 senatorial signatures made its way to President Ford's desk. The letter referenced the Vietnam War and how the U.S. needed reliable allies, as well as congressional participation in U.S. foreign policy. Additionally, the drive for peace in the Middle East required "that Israel obtain a level of military and economic support adequate to deter a renewal of war by Israel's neighbors. Withholding military equipment from Israel would be dangerous, discouraging accommodation by Israel's neighbors and encouraging a resort to force." Congress expected President Ford to request foreign aid for fiscal year 1976, and the letter urged that Ford "be responsive to Israel's urgent military and economic needs." Lastly, the letter pointed out that the reassessment was based on the need to find peace in the region, not on any weakening of the U.S. relationship with Israel. ${ }^{86}$ With more than three-quarters of the Upper Chamber calling for the renewal of aid shipments to Israel, while also advancing the Israeli hasbara position about the suspension of talks, the Ford Administration's reassessment, for all practical purposes, was over.

\footnotetext{
${ }^{83}$ Rafiah to Evron, 21 May 1975, MFA-CEO, Het, Tzadik - 6813/11, ISA.

${ }^{84}$ Rafiah to Evron, 19 May 1975, MFA-CEO, Het, Tzadik - 6813/11, ISA; Rafiah to Evron, 20 May 1975, MFACEO, Het, Tzadik - 6813/11, ISA.

${ }^{85}$ Rafiah to Evron, 21 May 1975, MFA-CEO, Het, Tzadik - 6813/11, ISA.

${ }^{86}$ Congress \& the Middle East: Senate Letter Condemning President Ford on Blaming Israel for Peace Process Suspension, https://www.jewishvirtuallibrary.org/jsource/US-Israel/fordsenblame.html, accessed 5 October 2015.
} 
The Senate letter was a tremendous achievement for Israel. According to Dinitz, the letter reaffirmed the importance of military and economic aid for Israel at a crucial time. Ten freshman senators signed the letter, which demonstrated that the new class of senators would support Israel. Moreover, the letter was headline news in major newspapers and was sent during the midst of reassessment. Ultimately, Dinitz recognized that the letter signaled to the world that U.S. support for Israel had not lessened. ${ }^{87}$ Foreign Minister Allon wrote back, "Dinitz, I would like to convey my appreciation to you and the friends from the embassy, and especially Morris Amitay and his assistants for the impressive and encouraging accomplishment ... This statement of support for Israel, which itself is important, has a special meaning considering the recent political developments. $" 88$

Understandably, the letter was not well-received by the Ford administration. According to Sidney Sober, Deputy Assistant Secretary of State for Near East and South Asian Affairs, the letter was seen as an attack on the Administration and Israel needed to be aware of that. "He personally does not see it as completely negative," reported Turgemon, "but many people in the Administration are quite upset." Sober also warned to not mess with Kissinger or criticize him in public because he was the most powerful person. Turgemon said Israel would not do that and it appreciated "all the good efforts he has done in the past." Turgemon told Sober that the letter was not an attack on the Administration, but importantly, the letter disproved the writings of "certain reporters that said there was a change in the U.S.-Israel relationship." 89

However shortly after the letter was sent to Ford, a New York Times article by Terence Smith sent the Israeli embassy into a frenzy. The article claimed that the senatorial letter, which Israeli officials happily referred to as the "the spirit of the 76," convinced the Rabin

\footnotetext{
${ }^{87}$ Dinitz to Director General, 22 May 1975, MFA-CEO, Het, Tzadik - 6813/11, ISA.

${ }^{88}$ Allon to Dinitz, 22 May 1975, MFA-CEO, Het, Tzadik - 6813/11, ISA.

${ }^{89}$ Turgemon to Evron, 30 May 1975, MFA-CEO, Het, Tzadik - 6813/11, ISA.
} 
administration that it could continue to ignore the repeated requests by the Ford administration to come up with new ideas and move forward with the peace process. ${ }^{90}$ The day that the article appeared, Rafiah sent word that "Israel needs to immediately deny the Terry Smith article." According to Rafiah, the letter was "sold" to the senators by claiming that it would allow Israel to enter into negotiations. The assistants of Jackson, Javits, Clifford Case (R-NJ), and Birch Bayh (D-IN) all informed Rafiah that Israel needed to deny the article. Richard Perle, Jackson's assistant, "said that although he agrees Israel should not come with new suggestions, publicizing the theme in the manner it was done in the New York Times will be very damaging." 91

While the embassy sought to influence public opinion and political actions, there was also a limit to what Dinitz would agree to do. In light of the senatorial letter, Dinitz informed the Foreign Ministry of Israel that the Israeli embassy in Washington would not publish "an explosive paper" that was "a clear attack on Sadat prior to his meeting with Ford" in Salzburg, Austria, which was to happen in early June. Moreover, the paper suggested even more military support from the US, but since "the embassy had been trying to downplay that point" Dinitz said he would not publish the letter. ${ }^{92}$ In all likelihood, Dinitz realized that enough had been accomplished through the hasbara campaign and the Senate letter, and attempting to undermine Sadat's position would have perhaps alienated even senators and representatives in the aftermath of the Terence Smith article. Israel still needed to work with Sadat - as well as the U.S. government - in order to advance Israeli interests as part of the ongoing peace process.

\footnotetext{
90 Terence Smith, “Israel Resisting U.S. on Sinai Pact,” New York Times, 27 May 1975, accessed through ProQuest, 7 October 2015.

${ }^{91}$ Rafiah to Evron, 27 May 1975, MFA-CEO, Het, Tzadik - 6813/11, ISA.

92 Dinitz to Director General, 28 May 1975, MFA-CEO, Het, Tzadik - 6813/11, ISA.
} 
Ford met Sadat for the first time that June in Salzburg, and the meeting was a springboard to the next round of negotiations for a Sinai II agreement. When the agreement was signed in early September, Israel ceded to Egypt the Mitla and Giddi passes, along with the oil fields, in return for an Egyptian pledge of non-belligerency. However the key to the entire agreement - the crucial element that was absent in March 1975 - was the set of executive agreements concluded by the Ford administration in order to get both sides to agree to Sinai II. In doing so, the United States officially became the superpower sponsor of Israel. The Ford administration promised about $\$ 2$ billion in aid, ended the freeze on new arms shipments, agreed to not recognize the PLO until it agreed to UN Resolutions 242 and 338, and agreed to carefully coordinate strategy with Israel for any potential Geneva conference - all for a disengagement agreement unconnected to any peace plan. ${ }^{93}$ After almost two years of step-by-step diplomacy, and with the U.S. essentially buying the Sinai II agreement, there was little enthusiasm for further peace negotiations. Sadat needed to visit Jerusalem two years later in order to get Israel on board for a separate peace agreement; relations with Syria and Palestinians remain violent to this day. The special relationship between the U.S. and Israel, which had advanced by way of military aid packages and political support up to 1975, reached an unprecedented high with the Sinai II agreement, and established the baseline for decades of U.S.-Israel relations.

Israel proved remarkably able to influence domestic political opinion in the United States. Through meetings with U.S. government officials, members of the press, and coordination with the American Jewish community, Israeli officials managed to keep abreast with developments in the public and political spheres in order to undertake measures to better the Israeli position. It effectively allowed the Israeli strategy of playing for time, and then extracting

\footnotetext{
${ }^{93}$ Quandt, 168-169.
} 
concessions from the U.S. while taking Egypt out of the war. Quite certainly, the Israeli embassy, pro-Israel lobby, and U.S. Congress played crucial roles in this development.

Salim Yaqub, Steven Spiegel, and Galen Jackson all downplay the importance of the Senate letter. But they do so because the letter is considered only in connection to whether or not Kissinger and Ford continued step-by-step diplomacy or pursued a general agreement, and not the unprecedented, formal U.S. commitments to Israel in connection to Sinai II. According to Spiegel, "Israeli and Egyptian preferences and the lack of other viable options, not domestic pressures, moved Kissinger and Ford back to the step-by-step process." "94 Jackson admits that domestic politics mattered, but the reason the Ford administration did not have a showdown with Israel was because of Kissinger's fear of anti-Semitism in the United States, rather than pressure from Congress or the pro-Israel lobby. For his part, Yaqub cites Kissinger's memoirs to show that the State Secretary made a "private pact" with himself to resign rather than force an agreement on an unwilling Israel. ${ }^{95}$ Kissinger's memoirs, unfortunately, are silent about his meetings with American Jewish leaders and Israeli officials during reassessment. But according to Israeli records, the 7 April meeting between Dinitz and Kissinger revealed that the State Secretary had offered his resignation to Ford, who refused to accept it. ${ }^{96}$ That casts serious doubt on the accuracy of Kissinger's recollections in his memoirs, and also points to the importance of non-U.S. documentation.

Although the letter may not have changed the minds of Kissinger and Ford, without the threat of a potential Geneva conference or withholding aid, Israel was able to extract very significant concessions from the United States for another disengagement agreement. In all likelihood, the U.S. would not have pursued a general peace at a Geneva conference even if the

\footnotetext{
${ }^{94}$ Spiegel, 297.

95 Ibid., 243; Henry Kissinger, Years of Renewal (New York: Simon \& Schuster, 1999), 428.

${ }^{96}$ Dinitz to Director General, 8 April 1975, MFA-OFM, Het, Tzadik - 6853/8, ISA.
} 
Senate did not send Ford such a letter. Kissinger told Leo Garment on April 6 that he still preferred an interim agreement to Geneva. But the Senate letter forced the Administration to stop pressuring Israel. Without pressuring Israel to be more willing to pursue peace agreements - and Dinitz and Evron both indicated that the Israelis had used step-by-step diplomacy to play for time to avoid engaging in sincere peace discussions - then the only option to prevent war was another interim agreement. And Israel knew it. Egypt had no ability to give Israel what it really wanted - weapons and powerful political support in the international arena. That, along with getting Egypt out of the larger Arab war with Israel, was what Sinai II was all about for Israel. There was to be no comprehensive settlement, and the only option was a disengagement agreement with Egypt. Basically, the Administration was out of options and forced to conclude an interim agreement between Israel and Egypt, no matter what the cost, in order to avoid another Arab-Israeli war and near-certain oil embargo. It is difficult to imagine that the U.S. government would have sacrificed so much political and economic leverage over Israel with the Sinai II agreement if not for the "spirit of the 76", along with the Israeli hasbara and the Israeli embassy.

Gesture politics, while difficult to quantify, matter a great deal. The Boston Tea Party, for example, was not really about undercutting the profits of the East India Company; the Boston Tea Party was a message to London. The value of the Senate letter remains difficult to quantify, but with more than three-quarters of the U.S. Senate intentionally undermining presidential foreign policy - at the behest of a foreign nation - the "gesture" of the Senate letter stands as the strongest Israeli rebuke of U.S. foreign policy. And in combination with congressional assertiveness in ending the Vietnam War (Saigon fell less than a month before the Senate letter), 
the spring of 1975 stands as one of the most impactful periods of congressional influence on U.S. foreign policy.

When thinking about the influence of domestic politics on the Sinai II agreement, consider a counter-factual: What would have happened if 76 senators had signed a letter demanding no aid for Israel until it agreed to sincere, substantive peace discussions? One can imagine that historical events connected to the peace process, and of course historical scholarship about it, would tell a much different story about the importance of Congress and non-American agency for U.S. foreign policy in the Middle East. And as discussed next chapter, Congress's significance in foreign affairs can also be seen through its effort to "rein in" Presidential power in foreign policymaking, part of its ongoing challenge to the Imperial Presidency, by more closely monitoring Presidential Executive Agreements. 


\section{Chapter 7: \\ Sinai II and the Executive Agreements Review Act of 1975}

The 1975 Sinai II disengagement agreement, which redrew the military map in the Sinai Peninsula and transferred the Abu Rudeis oil fields from Israel to Egypt, was more than just a bilateral agreement between Israel and Egypt. Certainly, Sinai II was a crucial stepping-stone to Camp David a few years later. But the United States also played a central role by acting as mediator and including "incentives" for both countries. In order to secure acceptance of the agreement, the Ford White House agreed to a series of executive agreements with both Israel and Egypt. Controversial at the time, the executive agreements included significant aid packages to both countries, diplomatic pledges, and an early-warning station in the Sinai Peninsula to be manned by 200 U.S. civilian personnel. The move by the Ford administration irritated many members of Congress who believed the President needed to involve the legislature in foreign policy concerns, especially executive agreements.

Congress challenged the Sinai II executive agreements in a peculiar way, and one that demonstrates the importance of domestic politics in American foreign policy. Rather than take issue with the specific details of Sinai II, Congress instead challenged the constitutionality of such wide-ranging American commitments. For years, Congress had taken issue with the prolific use of executive agreements made by the White House that bypassed congressional consultation and consent, which is required by the Treaty Clause of the Constitution. In fact, Sinai II was agreed to while Congress was considering legislation to create a possible legislative veto for any executive agreement within the first 60 days - the Executive Agreements Review Act of 1975. The debates about executive agreements legislation and Sinai II essentially merged with H. J. Resolution 683 (1975), which authorized sending U.S. civilians to operate the early-warning station in the Sinai Peninsula. Although the joint resolution passed easily, it also included a 
potential legislative veto, required the President to submit bi-annual progress reports, and explicitly refused to endorse any other executive agreements associated with Sinai II. The legislation reflected deep divisions between the executive and legislative branches.

In 1975, Congress was attempting to rein in "the runaway Presidency" that had created an imbalance between the two branches. ${ }^{1}$ Relations between the White House and Congress had deteriorated after executive abuses, both domestic and foreign, during the Johnson and Nixon administrations. The midterm elections that took place shortly after Richard Nixon's resignation brought the "class of 1974" to Washington, D.C., which included many first-time legislators who, according to Loch K. Johnson, "came to Congress with what they considered a mandate to clean up the government." In his memoirs, Henry Kissinger recalled this "new and extremely liberal Congress," headed by George McGovern, was nearly constantly at odds with the Gerald Ford White House. ${ }^{3}$ In particular, Congress was challenging the White House over foreign policy issues, which had been the sacred realm of the executive branch. In a 2003 interview, Ford remembered, “There was, I thought, an unfortunate encroachment by the Congress on foreign power action by the United States ... Congress was trying to claw its way into the foreign policy arena, and that inevitably was a potential encroachment on presidential power."4

This chapter explores the relationship between Sinai II and the Executive Agreements Review Act of 1975 in an effort to show how domestic politics - and more specifically, congressional-executive relations - impacted the nature and extent of American executive agreements connected to Sinai II. On the surface, Congress seemed to send a strong message to

\footnotetext{
${ }^{1}$ Arthur Schlesinger, Jr., The Imperial Presidency (Boston: Houghton Mifflin Company, 1973, 1989 ), 392.

${ }^{2}$ Loch K. Johnson, America as a World Power: Foreign Policy in a Constitutional Framework, Second Edition (New York: McGraw-Hill, 1991, 1995), 197.

${ }^{3}$ Henry Kissinger, Years of Renewal (New York: Simon \& Schuster, 1999), 834-35.

${ }^{4}$ Yanek Mieczkowski, Gerald Ford and the Challenges of the 1970s (Lexington: The University Press of Kentucky, 2005), 281. Mieczkowski cites the August 21, 2003 interview with Ford in his notes (410).
} 
the White House by not explicitly endorsing the executive agreements and including safeguards like the legislative veto and bi-annual reports. But at the same time, beyond scolding the White House for making agreements that resembled treaties without senatorial consultation, Congress offered little substantive resistance. Rather than challenge the White House on foreign aid requests, which it had done with South Vietnam, Angola, and Turkey, Congress instead rewarded Israel and Egypt with combined aid packages totaling billions of dollars, all while the American economy was mired in a severe recession. In effect, Congress merely reserved the right to revise the executive agreements, primarily through its appropriations power, but did not actually influence Sinai II in any meaningful way. The Sinai II agreement represented a new era in American foreign policy in that Congress cut back on virtually all foreign aid except that to the Middle East, which portended the volatility and importance of the region for the foreseeable future. ${ }^{5}$

Most historians are probably unaware of the congressional response to Sinai II because the topic has not been given much attention; understandably, scholarship has often tried to situate Sinai II within the ongoing Arab-Israeli peace process. Harold Saunders has written a helpful chapter about congressional influences on U.S. foreign policy in the Middle East from 19731984, which includes a brief section on Sinai II, one of five case studies examined in the chapter. ${ }^{6}$ Aside from Saunders's work, the congressional response to Sinai II has been understated in scholarship. In his thorough account of Henry Kissinger's step-by-step diplomacy, Steven Spiegel rightly noted that some U.S. officials, like Adlai Stevenson, the two-time

\footnotetext{
${ }^{5}$ A different paper will better address why Congress was reluctant to challenge foreign aid requests to the Middle East.

${ }^{6}$ Harold H. Saunders, "The Middle East, 1973-1984: Hidden Agendas," in The President, the Congress and Foreign Policy: A Joint Policy Project of the Association of Former Members of Congress and the Atlantic Council of the United States, eds. Edmund S. Muskie, Kenneth Rush, and Kenneth W. Thompson (Lanham, MD: University Press of America, Inc., 1986), p. 175-205; for the section about Sinai II, see p. 187-191.
} 
Democratic nominee for President in 1952 and 1956, and George Ball, longtime diplomat and friend of Stevenson, questioned the cost/benefit of Sinai II; unfortunately, the actual ways in which Congress challenged the executive agreements are never explored. ${ }^{7}$ Similarly, William Quandt overlooks the congressional response to Sinai II in Peace Process, perhaps the most useful survey of American involvement in the Arab-Israeli conflict. ${ }^{8}$ Neither Edward Sheehan nor Matti Golan discusses the congressional response in the two full-length treatments of Sinai II. ${ }^{9}$ Some works have emphasized the importance of lobbying, and particularly the effectiveness of the pro-Israel lobby, such as the book by John Mearsheimer and Stephen Walt, The Israel Lobby and U.S. Foreign Policy. ${ }^{10}$ The implication of such studies is that lobbies and interest groups, primarily through Congress, are able to significantly influence American foreign policy. Yet the number of studies of interest groups has far outpaced the number of studies about the congressional role in shaping U.S. foreign policy in the Middle East. A fresh perspective of Sinai II is one that focuses on American commitments and the congressional response, rather than the progress of the peace process, in order to speak to American foreign policy broadly, as well as American involvement in the Arab-Israeli peace process during a crucial period of diplomacy. ${ }^{11}$

\footnotetext{
${ }^{7}$ Steven L. Spiegel, The Other Arab-Israeli Conflict: Making America's Middle East Policy, from Truman to Reagan (Chicago: The University of Chicago Press, 1985), 304. Spiegel points out that during 1975, Harold Saunders was deputy assistant secretary of state for Near East and South Asian affairs (306).

${ }^{8}$ William B. Quandt, Peace Process: American Diplomacy and the Arab-Israeli Conflict since 1967, $3^{\text {rd }}$ Edition (Washington D.C.: Brookings Institution Press, 2005), 166-170.

${ }^{9}$ Edward R. F. Sheehan, The Arabs, Israelis, and Kissinger: A Secret History of American Diplomacy in the Middle East (New York: Reader's Digest Press, 1976), and Matti Golan, The Secret Conversations of Henry Kissinger (New York: Quadrangle, 1976).

${ }^{10}$ John J. Mearsheimer and Stephen M. Walt, The Israel Lobby and U.S. Foreign Policy (New York: Farrar, Straus and Giroux, 2007).

${ }^{11}$ Beyond historical writings about Sinai, a number of fine works about Congress and its desire to play a larger role in foreign policy add much needed depth to this work. See: Arthur Schlesinger, Jr., The Imperial Presidency (Boston: Houghton Mifflin Company, 1973, 1989); Robert David "KC" Johnson, Congress and the Cold War (New York: Cambridge University Press, 2006); Gerald R. Ford, A Time to Heal: The Autobiography of Gerald R. Ford (New York: Harper \& Row, Publishers, 1979); and Henry Kissinger, Years of Renewal (New York: Simon \& Schuster, 1999).
} 
The history of executive-congressional debates about executive agreements is not a flashy history, but it is an important one for understanding American foreign relations, especially during the Cold War. In terms of agency, the federal government plays the primary role in developing and executing the ideology and financial support for American foreign policy. The use of executive agreements was widespread and fundamental to conducting foreign relations during the Cold War and remains so today. The discussion about the Executive Agreements Review Act of 1975 helped to define the boundaries of power in foreign affairs for the White House and Congress, and the Sinai II agreement provides an opportunity to explore those boundaries. Indeed, H. J. Resolution 683 is where Sinai II, the Executive Agreements Review Act of 1975, and U.S. involvement in the Arab-Israeli peace process all intersected.

An executive agreement is an international agreement, similar to a treaty, but does not require consultation with Congress. There are different types of executive agreements, and while scholars have categorized them in different ways, the common theme is that Congress became irritated with executive agreements that resembled treaties and did not include consultation with Congress. ${ }^{12}$ The Constitution grants the President the power to make treaties, but only "by and with the Advice and Consent of the Senate," and requires two-thirds of Senators present to concur. The Constitution does not formally and explicitly state that the President can enter into executive agreements; however, presidents have long used executive agreements to conduct American foreign policy and the practice has become an accepted element of executive power.

\footnotetext{
${ }^{12}$ Loch K. Johnson, The Making of International Agreements: Congress Confronts the Executive (New York: New York University Press, 1984), 3-30; Glen S. Krutz and Jeffrey S. Peake, Treaty Politics and the Rise of Executive Agreements: International Commitments in a System of Shared Powers (Ann Arbor: The University of Michigan Press, 2009), 30; Lawrence Margolis, Executive Agreements and Presidential Power in Foreign Policy (New York: Praeger Publishers, 1986), 26-27; and Nigel Purvis, "Paving the Way for U.S. Climate Leadership: The Case for Executive Agreements and Climate Protection Authority," Discussion Paper: Resources for the Future, April 2008, http://www.rff.org/documents/rff-dp-08-09.pdf (accessed January 12, 2014), 13-25.
} 
Executive agreements have been used for about two centuries. Lawrence Margolis agrees with Arthur Schlesinger, Jr. that the first executive agreement was the Rush-Bagot agreement in 1817, which was an agreement between the U.S. and Britain to limit naval forces on the Great Lakes. ${ }^{13}$ A more significant early executive agreement was the one made by President Tyler to annex Texas. Recognizing that he could not gain two-thirds support for a treaty, Tyler submitted a joint resolution to Congress that required only a simple majority of support. The measure narrowly passed the House and Senate, and as Margolis recognized, "for the first time an executive agreement was substituted for a treaty because of the recalcitrance of the Senate."14 The annexation of Texas led to war with Mexico, and fittingly, the war ended with an executive agreement that eventually became ratified as a treaty, similar to the Spanish-American War of 1898. ${ }^{15}$ Following WWI, Calvin Coolidge agreed to a series of thirteen executive agreements with European nations regarding the payback of debt accrued during the war. Although Congress had passed an earlier law that demanded full repayment of loans, it followed the president's lead and agreed to negotiate more lenient terms.

As presidential power increased with the Cold War, presidents began using executive agreements more frequently. During the 1930s and 1940s, executive agreements gradually outnumbered formal treaties, and in the post-WWII, Cold War political environment, the ratio became much more lopsided. For example, in 1935 the U.S. government entered into 25 treaties and 10 executive agreements, but in 1946 the ratio was 19 treaties to 139 executive agreements; the year with the greatest disparity was 1962, when the executive branch concluded 10 treaties

\footnotetext{
${ }^{13}$ Margolis, 5. According to Margolis, a 1792 agreement made by the U.S. Postmaster General with Britain about exchanging postal services with Canada has been viewed as perhaps the first executive agreement. However, Schlesinger, Jr., Edward S. Corwin, "and the Treaties and Other International Agreements series all concur that the first executive agreement was the Rush-Bagot agreement in 1817 ..." (5). However, Margolis includes his opinion that the Louisiana Purchase could be considered an executive agreement as well.

${ }^{14}$ Ibid., 9.

${ }^{15}$ Ibid.
} 
and 319 executive agreements. During the five years from 1969 through 1973, the U.S. government agreed to a total of 80 treaties and 1,087 executive agreements. ${ }^{16}$ The wisdom behind using more executive agreements rather than treaties was that in order to provide a flexible, yet credible response to communist activity overseas, the White House needed the freedom to make agreements with foreign nations in a timely and legitimate manner. Therefore, as U.S. foreign policy interests quickly expanded in the early Cold War, presidents began using such agreements with more frequency. Considering the sheer number of executive agreements each year, congressional oversight of each agreement was simply impossible. For the most part, executive agreements have been minor, unimportant items. But at times, from the perspective of the Congress, executive agreements have looked much like treaties and should have been submitted as treaties in order to receive the advice and consent of the Senate.

Bypassing congressional participation naturally produced backlash on Capitol Hill. The first major congressional action that aimed to limit presidential power in the area of executive agreements was the Bricker Amendment of 1953-54. Senator John Bricker, an Ohio Republican, sponsored a series of amendments in the 1950s that aimed to redefine congressional-executive relations in the areas of treaties and executive agreements. The most significant amendment was introduced in 1953, debated and decided in 1954, and ultimately aimed "to regulate all executive and other agreements with any foreign power or international organization." ${ }^{17}$ In addition to legislating regulatory control of executive agreements, the amendment cleverly equated executive agreements with treaties, not to strengthen the president's hand, but rather to require

\footnotetext{
${ }^{16}$ Marjorie Ann Brown, "Executive Agreements: A Survey of Recent Congressional Interest and Action," Congressional Research Service: Library of Congress, Foreign Affairs Division, September 10, 1974, Appendix A. Found in Record Group 233: Records of the United States House of Representatives, 94th-95th Congress, Committee on Foreign Affairs, Executive Agreements (files of George R. Berdes), Box No. 2, Folder: Executive Agreements: Gen. Reference \& Background Material.

${ }^{17}$ Philip A. Grant, "The Bricker Amendment Controversy," Presidential Studies Quarterly, Vol. 15, No. 3, Summer, $1985,573$.
} 
the same type of constitutional participation prescribed by the Constitution for treaties. Although Bricker had initial support for his amendment, President Eisenhower and Senate Majority Leader Lyndon Johnson both opposed the measure and, in their separate ways, actively worked to defeat it. $^{18}$

In the nearly twenty years between the Bricker Amendment and the Executive Agreements Review Act of 1975, Congress became increasingly concerned with unchecked presidential power. Congress had intentionally deferred power to the president to more effectively handle American foreign policy during the Cold War, evidenced by the Truman Doctrine and Tonkin Gulf Resolution, a period which Arthur Schlesinger, Jr. has called, the Imperial Presidency. However, a series of poor (and illegal) decisions made by successive administrations prompted action by Congress. The debate about executive agreements was part of this larger desire to increase legislative power in foreign affairs, marked especially by the War Powers Act of 1973, which forced the president to secure congressional approval of American military forces deployed abroad after a period of 60 days.

In the years leading up to the Executive Agreements Review Act of 1975, the Senate passed a series of resolutions that either directly or indirectly affected executive agreement. The first was the National Commitments Resolution of 1969. After two years of debate and investigation, the Senate passed a non-binding resolution that defined a national commitment as "the use of U.S. armed forces on foreign territory or a promise to assist a foreign country, government, or people by the use of the U.S. armed forces or financial resources," and that a U.S. national commitment should result "only from affirmative action taken by the executive and legislative branches of the United States Government by means of a treaty, statute, or concurrent

\footnotetext{
${ }^{18}$ Congress and the Cold War, 59-60.
} 
resolution of both Houses of Congress specifically providing for such commitment." ${ }^{19}$ Although this resolution did not have the power of law, it voiced a congressional concern about executive foreign policy and was an important precursor to the War Powers Resolution of 1973, which legally prohibits the president from committing U.S. armed forces abroad for more than 60 days without congressional approval.

Furthermore, the resolution contributed to a growing expectation by the Senate to a play a larger role in any executive agreements that included promises of economic or military aid. This led to two separate clashes between the executive and legislative branches that would impact the evolving debate about executive agreements. The first, in 1970, involved an executive agreement with Spain that provided for American use of bases in Spain, which extended a 1953 agreement. ${ }^{20}$ The Senate Foreign Relations Committee commented that "the majority of committee members still adhere to the opinion that the administration should have submitted the agreement as a treaty," which would have required the advice and consent of the Congress. ${ }^{21}$ This reflected the majority opinion of the Senate, which passed a resolution that expressed "the sense of the Senate that nothing in the agreement with Spain should be deemed to be a national commitment by the United States.",22

The Senate went even further two years later. By a 50-6 vote, the Senate passed a nonbinding resolution regarding executive agreements with Portugal and Bahrain. The resolution firmly stated that "any agreement with Portugal or Bahrain for military bases or foreign assistance should be submitted as a treaty to the Senate for advice and consent." ${ }^{23}$ The Foreign Relations Committee, which introduced the resolution, was concerned "that 'no lesson' had been

\footnotetext{
${ }^{19}$ Brown, 7-8.

${ }^{20}$ Ibid., 8.

${ }^{21}$ Ibid., 8-9.

${ }^{22}$ Ibid., 8.

${ }^{23}$ Ibid., 10.
} 
learned from the experience with the Spanish base agreement," and that the two executive agreements raised "important foreign policy questions" that could be better addressed if the agreements were submitted as treaties. ${ }^{24}$

Congressional interest in executive agreements continued with passage of the Case Act in 1972. Senator Clifford Case (R-NJ), who led the senatorial charge against the agreements with Portugal and Bahrain, sponsored a bill that required the president to report all executive agreements within 60 days of their commencement. Case argued that Congress had a constitutional right to have access to the details of all international agreements. The Case Act attracted broad support and easily passed. The Nixon White House offered little resistance because the legislation did nothing to affect the power of the President to enter into executive agreements; instead, the Act simply required a sharing of information between the executive and legislative branches.

Obviously frustrated with what it regarded as treaties being submitted as executive agreements, Senator Sam Ervin Jr. (D-North Carolina) sponsored a bill (S. 3475) in April 1972 that included a possible legislative veto of an executive agreement within 60 days by concurrent resolution of both Houses. As Schlesinger, Jr. points out, Congress believed "it could best restrain the Presidency by enacting specific legislation in the conspicuous fields of presidential abuse. The main author of this comprehensive congressional attack on presidential supremacy was, well before Watergate, Senator Sam Ervin of North Carolina." ${ }^{25}$ Ervin had served as Chair of the Senate Watergate Committee and took on Nixon over the issue of executive privilege on several occasions; the bill about executive agreements was part of Ervin's ongoing attempt to

\footnotetext{
${ }^{24}$ Ibid.

${ }^{25}$ Schlesinger, Jr., 392.
} 
create a better balance of power between the two branches. ${ }^{26}$ When introducing the bill on the Senate floor, Ervin referenced "so-called executive agreements," that "have been utilized time and time again in situations where many legal scholars believe that the treaty provisions of section 2, article II of the Constitution should have been followed." ${ }^{27}$ According to Ervin, "the Founding Fathers' concept of shared powers in the area of international agreements has been substantially eroded by the use of so-called executive agreements, ${ }^{28}$ and therefore legislation was necessary to ensure proper balance. The Ervin bill was the strongest congressional challenge to presidential use of executive agreements since the Bricker Amendment, and like the earlier measure, Ervin sought to regulate all executive agreements as though they were treaties.

The Judiciary Subcommittee on the Separation of Powers, chaired by Ervin, conducted a series of five hearings to consider his proposal. ${ }^{29}$ Retired Supreme Court Justice Arthur Goldberg was the first witness before the subcommittee. Before offering his assessment of the legislation, Goldberg spoke to the divisive relationship between the White House and Capitol Hill. "It is an understatement," said Goldberg, "to observe that we are approaching, if we have not already reached, a constitutional crisis in the relations between the Executive and Congress." ${ }^{30}$ Goldberg was sympathetic with the congressional effort to create a better balance of power in foreign affairs. He saw the imbalance arising from Congress being "derelict in the performance of its constitutional responsibilities while the Executive has been over-assertive in extending its authority beyond the Constitution." 31 Goldberg viewed Ervin's bill as an opportunity to create a

\footnotetext{
${ }^{26}$ Ibid., 392-410.

${ }^{27}$ U.S. Senate, Subcommittee on Separation of Powers, Hearings, Congressional Oversight of Executive Agreements - 1972, 92nd Congress, p. 357; [From the Congressional Record, Vol. 118, No. 56, April 1, 1972].

28 Ibid.

29 The hearings were April 24 and 25, 1972 and May 12, 18, 19, 1972.

${ }^{30}$ U.S. Senate, Subcommittee on Separation of Powers, Hearings, Congressional Oversight of Executive Agreements - 1972, 92nd Congress, p. 10.

${ }^{31}$ Ibid., 12.
} 
better balance, and in a way that did not unconstitutionally restrict the president to conduct foreign affairs.

Not surprisingly, the executive branch did not share in Goldberg's enthusiasm for the Ervin bill. John Stevenson, legal adviser for the Department of State, opposed the bill for two reasons. First, on a practical level, the grace period of 60 days "would be extremely disadvantageous in a number of situations in which a rapid resolution of practical problems is essential." 32 The second and more significant objection was a constitutional one. The problem with the Ervin bill, according to Stevenson, was that it sought to regulate all executive agreements, and "it is clear that there are some agreements - though probably an extremely small number which it is solely within the President's authority to conclude and with which the Congress may not constitutionally interfere. ${ }^{\prime 33}$ In that sense, the Ervin bill closely resembled the Bricker amendment in that it sought to regulate all executive agreements. In doing so, however, the bill would infringe on the president's power to negotiate foreign agreements. Similarly, the Office of Legal Counsel for the Department of Justice opposed the Ervin bill for constitutional reasons. ${ }^{34}$ Implicit in this line of reasoning is that Congress would be better off challenging executive agreements on a case-by-case basis.

The Ervin bill failed to attract enough support and no action was taken on the bill in the $92^{\text {nd }}$ Congress. However, just months before he was set to retire from the Senate, Ervin reintroduced his bill on July 30, 1974. A slightly-amended measure passed the Senate on November 21, 1974, but ultimately died in the House Rules Committee. ${ }^{35}$

\footnotetext{
${ }^{32}$ Ibid., 259.

${ }^{33}$ Ibid.

${ }^{34}$ Ibid., 308.

${ }^{35}$ U.S. Senate, Subcommittee on Separation of Powers, Hearings, Congressional Oversight of Executive Agreements $-1975,94^{\text {th }}$ Congress, p. 1. Antonin Scalia discusses the amendment, which deleted the word "specific" within the phrase, "exempting only executive agreements made pursuant to 'specific' provisions of the Constitution or laws." (171).
} 
Although the Ervin bill died in the House, it inspired several other pieces of legislation that would ultimately comprise the Executive Agreements Review Act of 1975. As of March 1975, six separate bills about executive agreements were being considered by Congress, two in the Senate and four in the House. ${ }^{36}$ The House proposed its strongest version of the Executive Agreements Review Act on March 6, 1975. Thomas Morgan (D-PA), Chair of the International Relations Committee, introduced a bill much like the Ervin bill that proposed a legislative veto of an executive agreement for the first 60 days. Different from the Ervin bill, however, was that "the measure is limited to those agreements which involve significant national commitments abroad such as military base agreements." ${ }^{37}$ In doing so, Morgan addressed two specific areas mentioned in recent resolutions - national commitments and military bases. Clement Zablocki (D-WI), co-sponsor of the Case Act, joined with Morgan in proposing the legislation, as did 26 other representatives. "Much in the spirit of the War Powers Act," remarked Zablocki on the House floor, "the enactment of this bill would allow Congress to reassert its Constitutionallymandated powers by requiring the Executive Branch to submit to Congress for review each executive agreement concerning a national commitment." 38

In the Senate, the more important of the two bills was the one sponsored by Ohio Democratic Senator John Glenn (S. 1251). Similar to legislation in the House, the Glenn bill proposed a legislative veto of an executive agreement within 60 days by way of a simple concurrent resolution, though only by the Senate. As to which committee would consider the legislation, the Glenn bill first "was referred consecutively to the Committee on Government

\footnotetext{
${ }^{36}$ S. 632, S. 1251, H.R. 1268, H.R. 1273, H.R. 4438, and H.R. 4439.

37 "Remarks by the Honorable Thomas E. Morgan, Upon Introduction of the Executive Agreements Review Act," page 1, Record Group 233: Records of the United States House of Representatives, 94th-95th Congress: Committee on Foreign Affairs, Executive Agreements (files of George R. Berdes), Box \#2, Folder: Executive Agreements Legislation.

38 "Remarks of Hon. Clement J. Zablocki, March 6, 1975," page 1, Record Group 233: Records of the United States House of Representatives, 94th-95th Congress: Committee on Foreign Affairs, Executive Agreements (files of George R. Berdes), Box \#2, Folder: Executive Agreements - Legislation.
} 
Operations and Foreign Relations." 39 Senator Robert Griffin (R-Michigan) objected to the Foreign Relations Committee serving in a secondary role, but the legislation proposed by Glenn specifically called for Government Operations to take the lead. ${ }^{40}$ And unfortunately for the Foreign Relations Committee, the following day the Government Operations Committee discharged the bill to the floor and it was referred to the Judiciary Committee, the same home for the other Senate bill that was proposed by Senator Lloyd Bentsen, Jr. (D-Texas). Judiciary had managed to get both pieces of legislation and undertook another series of hearings between May and July to consider the bills.

The Foreign Relations Committee had good cause for requesting greater participation in the congressional debate about executive agreements. The Committee was responsible for collecting all information about executive agreements as mandated by the Case Act, and the Ervin bill had been sent first to Foreign Relations for consideration. Adding to the Committee's frustration, a deficiency in executive branch reporting of executive agreements was discovered during a February 6, 1975 meeting between Foreign Relations staff members and State Department officials, headed by Assistant Legal Adviser Charles Bevins. ${ }^{41}$ Both sides had legitimate points. The State Department admitted that other agencies and departments, like Defense, conclude executive agreements that are never seen by State, and therefore not properly submitted to the Foreign Relations Committee. But considering the large number of executive

\footnotetext{
${ }^{39}$ Dave Keaney to Don Henderson, March 21, 1975, Record Group 46: Records of the U.S. Senate, 94th Congress: Committee on Foreign Relations, Legislative Files: S. 961-S. 1350, Box \#5, Folder: "S. 1251 Glenn 3/20/75 Improved Govt. organ. re int'l agree.”

${ }^{40}$ Congressional Record, Senate, Thursday, March 20, 1975, "S. 1231 - Executive Agreements Review Act," S 4467; also found here: Record Group 46: Records of the U.S. Senate, 94th Congress: Committee on Foreign Relations, Legislative Files: S. 961-S. 1350, Box \#5, Folder: "S. 1251 Glenn 3/20/75 Improved Govt. organ. re int'l agree.".

${ }^{41}$ Memorandum of Conversation, Participants: Don Henderson, Morella Hansen, Dave Keaney, Charles Bevins, et. al., February 11, 1975, "Re: Case Act Requirements - Executive Agreements," Record Group 46: Records of the U.S. Senate, 94th Congress: Committee on Foreign Relations, Legislative Files: S. 961-S. 1350, Box \#5, Folder: "S. 1251 Glenn 3/20/75 Improved Govt. organ. re int'l agree."
} 
agreements each year, the State Department did not want to burden the Committee (or itself) with reporting unimportant agreements. But the Case Act clearly called for the communication of all executive agreements, and the executive branch had a poor track record when it came to choosing which information to share with Congress.

The White House was determined to defeat the legislation. In a memorandum written to Ford, Kissinger offered his assessment of the situation and a possible strategy. He first noted that several pieces of legislation had been introduced in both the House and Senate, "including a very formidable one sponsored by Chairman Morgan and 26 other members of the House Committee on International Relations," and that the bills "appear to have widespread support." ${ }^{\text {" } 2}$ Kissinger considered the legislation "in many ways reminiscent of the defeated Bricker Amendment proposals of the 1950 's," and recommended a strategy similar to the one employed by the Eisenhower White House. Kissinger made three specific recommendations to Ford that could be used to defeat the bill: "Your meeting soon with key Congressional figures; Strong lobbying efforts by the White House, supported by the Departments of State, Defense and Justice; Mobilizing the support of bar associations throughout the country and of prominent members of the legal community." ${ }^{43}$ This strategy was on display at the Senate subcommittee hearings about executive agreements legislation.

The Senate Subcommittee on Separation of Powers, part of the Judiciary Committee, considered the two senatorial bills (632 and 1251) about executive agreements during the course of four scheduled hearings (May 13, 14, and 15, with the final hearing on July 25, 1975). The

\footnotetext{
${ }^{42}$ Memorandum for the President, From Henry A. Kissinger, "Congress and Executive Agreements," p. 1. Found in Record Group 233: Records of the United States House of Representatives, 94th-95th Congress, Committee on Foreign Affairs, Executive Agreements (files of George R. Berdes), Box No. 2, Folder: Executive Agreements: Executive Branch Support (position). Although the document is undated, Kissinger mentions the upcoming Senate subcommittee hearings scheduled for May, which puts the date somewhere between March 21 and May 14, and likely sometime in April.

${ }^{43}$ Ibid., 2.
} 
subcommittee was chaired by the junior Democratic Senator from South Dakota, James Abourezk. In his opening statement, Abourezk defended both the constitutionality of the proposed legislation, as well as the broader congressional desire to play a more direct role in American foreign policy, especially in light of executive abuses of power. ${ }^{44}$ Particularly irritating to Abourezk was a recent revelation of undisclosed executive agreements made by President Nixon with South Vietnam President Nguyen Van Thieu. The 1973 correspondence between the two leaders had been published in the New York Times on May 1, 1975, just two weeks before the hearings. Nixon had pledged that if North Vietnam violated the Paris cease-fire accords, the U.S would "take swift and severe retaliatory action" and would "respond with full force."45 "Let me emphasize," said Abourezk, "that the text of these letters is taken from the Times; both the State Department and the President have refused formal requests which I lodged with them for these documents. ${ }^{" 46}$ The secret agreement made by Nixon was technically an executive agreement, which brought into sharp focus (at least for Abourezk and the subcommittee) the need for stronger congressional control of executive agreements.

The hearings in 1975 were quite similar to the hearings conducted three years earlier by Ervin, along with an unfavorable response. David M. Sale, a legislative attorney for American Law Division, prepared an analysis of the two Senate bills (and H.R. 4438) for the Congressional Research Service of the Library of Congress just a week before the start of the hearings. "The central constitutional question which arises under the three bills," according to Sale, "concerns the validity of the 60 day rule and the concurrent resolution device. ${ }^{37}$ According to all three bills, an executive agreement would not go into force until 60 days after the conclusion of the

\footnotetext{
${ }^{44}$ U.S. Senate, Subcommittee on Separation of Powers, Hearings, Congressional Oversight of Executive Agreements - 1975, 94th Congress, p. 1-4.

${ }^{45}$ Ibid., 322.

${ }^{46}$ Ibid., 3.

${ }^{47}$ Ibid., 275.
} 
agreement, during which time a concurrent resolution could void the agreement. The problem, according to Sale, was that "Congress would not seem to possess the constitutional power either to delay the immediate legal effect of these agreements, or to disapprove of them by concurrent resolution." ${ }^{48}$ Sale also pointed out that "a Congressional attempt to disapprove of an agreement by concurrent resolution may be unconstitutional," a point that was "raised repeatedly during the Senate's consideration of similar legislation in 1972." ${ }^{49}$ Another possible objection to the legislation was that it would impinge upon the President's ability to serve as negotiator. Similar to other objections, this had been discussed during the hearings in 1972. Sale reminded the subcommittee that the "argument was urged by the State Department in 1972," based on a 1936 ruling in United States v. Curtiss-Wright Export Corporation. ${ }^{50}$ In other words, the pending legislation would likely be deemed unconstitutional if it managed to be passed by a $2 / 3$ majority and brought before the Supreme Court. Considering Sale was employed by the Congressional Research Service and not the State Department (or any area of the executive branch), his failure to endorse the legislation foreshadowed the fate of the Executive Agreements Review Act of 1975.

The State Department gave another unfavorable opinion of the legislation. Monroe Leigh, Legal Adviser for the Department of State, argued the bills "rest upon an assumption that there is no independent constitutional authority in the president to conclude executive agreements," although the Court has recognized the President's ability to enter into executive agreements without consulting Congress. ${ }^{51}$ Similar to Sale, Leigh pointed out that the legislative veto was another area of constitutional deficiency. Leigh admitted that concurrent resolutions that

\footnotetext{
${ }^{48}$ Ibid.

${ }^{49}$ Ibid. Sale was referring to the argument made by John R. Stevenson, Legal Adviser of the Department of State.

${ }^{50}$ U.S. Senate, Subcommittee on Separation of Powers, Hearings, Congressional Oversight of Executive Agreements - 1975, 94th Congress, p. 277.

${ }^{51}$ Ibid., 34.
} 
provided for a legislative veto had been enacted since the 1930s, but he also noted that they "have been attacked on constitutional grounds by many authorities on constitutional law. There have been no court tests of the validity of any of these acts, and the constitutional law questions they raise are not settled." ${ }^{52}$ Moreover, legislative vetoes were used when the President had been granted legislative authority, such as with the Reorganization Acts of the 1930s and 1940s. But the ability of the executive branch to conduct foreign relations is an executive power, not a legislative one. In other words, the legislature does not grant the President authority to conduct foreign relations - that right is guaranteed by the Constitution. Thus, a legislative veto was an inappropriate tool because there was no designation of legislative power to the executive branch. In the case, of the War Powers Act, Congress can legitimately claim to delegate to the President a legislative right to send U.S. military forces abroad, which allowed for a privileged legislative veto. But according to Leigh, "the Bentsen and Glenn bills would carry the legislative veto far beyond those areas for which any constitutional justification has ever been advanced to date." ${ }^{53}$ Former Supreme Court Justice Antonin Scalia, who at the time was Assistant Attorney General, also voiced his opposition to the legislation. Abourezk welcomed Scalia by pointing out "that the administration witnesses have been arguing for 2 days the same old administration line in opposition to this legislation," and that he hoped Scalia's "testimony on behalf of the Justice Department will provide us with some new insights, instead of trotting out the same old arguments." ${ }^{4}$ Scalia responded, "I hope so, too, Mr. Chairman, but lest you get your hopes up, the conclusion is, at least, the same." ${ }^{55}$

\footnotetext{
${ }^{52}$ Ibid., 36.

${ }^{53}$ Ibid.

${ }^{54}$ Ibid., 167.

${ }^{55}$ Ibid.
} 
Although he did notice substantive differences between the pending legislation and the 1972 Ervin bill, which had not been endorsed by the Senate, Scalia still deemed the legislation to be constitutionally defective. Scalia echoed Leigh's two main objections - first, that Congress cannot restrict Presidential power guaranteed by the Constitution, and second, that neither a concurrent resolution (S. 632) nor a Senate resolution (S. 1251) could be used to restrict Presidential power. ${ }^{56}$ Unfortunately for Abourezk, Glenn, Bentsen, Morgan, and other congressional members who favored the proposed legislation, the subcommittee hearings revealed little legal support for any legislation that sought to regulate executive agreements.

Congress's increasing antipathy towards executive agreements meant a showdown between the two branches was imminent over the Ford administration's negotiation of the Sinai II agreement. Shortly after the hearings in 1975 , the Ford White House successfully mediated an agreement between Israel and Egypt called Sinai II, which was signed on September 4, 1975. It was the third and final disengagement from the 1973 October War. ${ }^{57}$ Regarding the bilateral agreement, Egypt regained control of the strategic Mitla and Giddi passes in the Sinai Peninsula, along with the Abu Rudeis oil fields, in return for an Egyptian commitment to resolve any conflict by peaceful means. The Israeli military line in the Sinai moved approximately ten miles back, leaving their position to be filled by the Egyptians. The limited zone was demilitarized to no more than 8,000 men in eight battalions, with 75 tanks and 72 short-range artillery pieces.

\footnotetext{
${ }^{56}$ Ibid.

${ }^{57}$ Sinai I, a disengagement of Israeli and Egyptian forces in the Sinai Peninsula, was agreed to in January 1974; an Israeli-Syrian disengagement was concluded in May 1974.
} 
The United States agreed to man and supervise an early-warning system in the buffer zones as spelled out in detail in the agreement itself. ${ }^{58}$

In order to secure acceptance by both sides, the Ford White House agreed to a series of executive agreements with both Israel and Egypt. From the perspective of the Congress, the executive agreements connected to Sinai II were national commitments and another example of unchecked presidential power in foreign affairs; the debate about these agreements reflected the broader congressional concern about substituting treaties with executive agreements. Although Congress was unable to muster support for legislation that regulated all executive agreements, the Sinai II agreement offered Congress another opportunity to regulate executive agreements on a case-by-case basis, as it did with Spain, Portugal, and Bahrain.

However the congressional response to Sinai II - similar to executive agreements with Spain, Portugal, and Bahrain - had less to do with foreign policy and more to do with domestic politics. Rather than pursue an alternate path to foreign policy in the Arab-Israeli peace process or challenge the substance of the executive agreements (especially aid promises), Congress merely voiced its displeasure about the nature of the agreements from a constitutional perspective and ultimately bowed to the wishes of the White House. In doing so, Congress missed an opportunity to genuinely and meaningfully assert itself in American foreign policy, and through its inaction, actually reaffirmed the power of the White House during a time of contentious relations between the two branches.

That is not to say, however, that Congress silently accepted Kissinger's diplomatic achievement. The legacy of the Vietnam War was especially important; Saigon had fallen to

\footnotetext{
58 "To Implement the United States Proposal for the Early-Warning System in Sinai," Report of the Committee on International Relations together with Supplemental and Additional Views on House Joint Resolution 683, October 6, 1975 (Washington: U.S. Government Printing Office), p. 31-38.
} 
North Vietnamese forces only months earlier, which was an ignominious reminder of executive mismanagement of American foreign policy.

The debate about sending American personnel to man an early-warning station in the Sinai Peninsula understandably drew comparisons to Vietnam. Ford and Kissinger tried to allay Congressional fears in a meeting with bipartisan congressional leadership on September 4. Ford called American participation in the Sinai Peninsula "absolutely crucial to the settlement," and added that the National Security Council "thoroughly discussed" the issue, and that each member of the Council "agreed that our participation was a good idea and they approved our making such a proposal. ${ }^{, 59}$ But Speaker of the House Carl Albert (D-Oklahoma) reminded the meeting, "I believe that I am one of the few here who can remember when Secretary of State [John Foster] Dulles urged the Congress to approve sending 800 technicians to South Vietnam. ${ }^{.60}$ Albert mentioned, however, that "the situation here is basically different" because "both sides have requested our participation, and we are not putting Americans into an active conflict. These Americans will be civilians, not military." Congressional concern was best articulated by Senator Mike Mansfield (D-Montana): "I am very much concerned that the United States for the first time is making a commitment of personnel to the Middle East. Whether they are military or civilian is beside the point." Between the promise of U.S. personnel and sizeable aid packages, for Mansfield, "All of this seems to me to be a pretty stiff price to pay for a very small withdrawal." ${ }^{61}$

Another point of contention was the "secret" nature of the executive agreements. While the bilateral agreement between Israel and Egypt was reported openly, the American executive

\footnotetext{
${ }^{59}$ National Security Council Meeting with Bipartisan Congressional Leadership, Memorandum for the Record, September 4, 1975, National Security Advisor, NSC Press and Congressional Liaison Staff: Files, 1973-1976, Box 8, September 4, 1975 - Bipartisan Leaders (MEMCON - Middle East Agreement), Gerald R. Ford Library.

${ }^{60} \mathrm{Ibid}$.

${ }^{61}$ Ibid.
} 
agreements were concluded secretly. In the post-Vietnam, post-Watergate era, Congress wanted to make foreign policy more transparent and accessible to the public. A statement released by Senator Case on September 4 stated, "It is my belief that there is no such thing as a valid secret United States commitment." Such commitments, according to Case, "require the approval of the Congress and the American people." ${ }^{\circ 2}$ A White House document from September 12 recognized that "there is bipartisan concern about the secret elements of the agreement." Many congressional members did not "wish to be party to a secret agreement because of post-Vietnam fears," and thus wanted "to make public as much as possible of the entire agreement." Complicating the situation, the details of the secret agreements were leaked to newspapers and appeared in Washington Post and New York Times articles on September 16, which only added to the atmosphere of mistrust swirling about Washington. In an effort to advance an image of transparency, on October 3 the Senate Foreign Relations Committee "voted 12 to 2 to release the attached documents provided by the Department of State in connection with the Sinai disengagement proposal, ${ }^{, 64}$ thereby making public the secret agreements.

More than secret agreements, Congress was particularly irritated by another set of substantial executive agreements not being submitted to Congress as treaties. The White House submitted to Congress only the portion of the agreement about U.S. participation in the early warning station, but not any of the secret agreements. The White House informed the relevant committees in the House and Senate about U.S. pledges to Israel and Egypt, but did not see the

\footnotetext{
${ }^{62}$ Statement by Senator Clifford P. Case on Congressional Approval of U.S. Personnel in the Sinai Area and Approval of United States Commitments To Israel and To Egypt, From the Office of Senator Clifford P. Case (RNJ), September 4, 1975, Max L. Friedersdorf, Box 14, Middle East, Gerald R. Ford Library.

${ }^{63}$ Timetable for House Action on Sinai Agreement, Memorandum for Jack Marsh, September 12, 1975, Max L. Friedersdorf, Box 14, Middle East, Gerald R. Ford Library.

${ }^{64}$ United States Senate Committee on Foreign Relations - For Immediate Release, October 3, 1975, Max L.

Friedersdorf, Box 14, Middle East, Gerald R. Ford Library.
} 
need to submit these agreements for ratification by Congress. In the case of the Sinai technicians, however, the White House wanted congressional approval.

Both the House and Senate conducted hearings to discuss the executive agreements. The House Committee on International Relations went first with hearings on September 8, 11, 18, and 25, while the Senate Foreign Relations Committee followed shortly thereafter with hearings on October 6 and 7. The hearings were ostensibly to discuss sending 200 U.S. civilians to man an early warning station in the Sinai, but the discussion usually focused on executive agreements and prospects for peace in the Middle East. While the joint resolution approved by Congress to send U.S. technicians to the Sinai passed both the House and Senate, the resolution itself used language and safeguards that reflected a larger concern with presidential power, and in a manner consistent with the Executive Agreements Review Act of 1975.

Kissinger was the first witness to appear before the House, and Under Secretary of State Joseph Sisco followed with testimony on September 11 and 18. Most interesting, Kissinger addressed the charge that the U.S. purchased the agreement, and did not deny it. "I have read in the press," said Kissinger, "many statements to the effect that the United States bought this agreement in the Sinai by the promise of military and economic aid to both of the parties." 65 Kissinger reminded the Committee that "economic and military aid to Israel has been an unchallenged premise of every known aid bill before every Congress. More frequently than not, the Congress has increased the administration request." 66 He even referenced a May 21, 1975 letter to Ford, signed by 76 Senators, which urged the President to be responsive to Israeli aid requests. Regarding Egypt, Congress had appropriated \$250 million in foreign aid the previous

\footnotetext{
65 "Middle East Agreements and the Early Warning System in the Sinai," Hearings of the Committee on International Relations, House of Representatives, Ninety-Fourth Congress, First Session on the Middle East Agreements and Legislation to Implement the United States Proposal for the Early-Warning System in Sinai, September 8, 11, 18, and 25, 1975 (Washington: U.S. Government Printing Office, 1975), 8. 66 Ibid.
} 
year, and the Ford administration had been "planning for a substantial increase in this amount without the agreement. ${ }^{367}$ According to Kissinger, the additional funds required would be "relatively small." 68

While Kissinger made a fair point, he also understated some of the more significant executive agreements. For example, the White House pledged to seriously consider selling Israel Pershing missiles, which could potentially carry a nuclear warhead. Such a move would potentially send more sophisticated weaponry to the Middle East, and in a way that further weighed the military scale in Israel's favor. The U.S. also agreed to align its foreign policy goals with Israel, with respect to the ongoing peace process, which meant not pursuing a multilateral peace at Geneva, nor recognition of the PLO (Palestine Liberation Organization) until it formally recognized Israel's right to exist. Additionally, the White House agreed to provide Israel with oil in the event of an oil embargo, which amounted to being compensation for giving up the Abu Rudeis oil fields. Those agreements, combined with U.S. participation in the early-warning station in the Sinai and substantial aid packages, amounted to being one of the costliest peace agreements ever entered into by the United States, and one that did not guarantee peace. When Kissinger communicated to the House that Sinai II did not represent much change from envisioned aid packages, he was only partially accurate.

With Sisco, the House Committee demonstrated its lack of patience for secrecy. In his first meeting, Sisco had asked for, and received, an executive session by a vote of 18 to 1 , during which he informed the Committee about the details of the executive agreements. But two days before his second meeting, the details of the secret agreements appeared in the press. This upset the Committee, which is why Sisco's motion for executive session on September 18 was voted

\footnotetext{
${ }^{67}$ Ibid.

${ }^{68}$ Ibid.
} 
down, "7 ayes and 11 nays." ${ }^{69}$ The Committee questioned the administration's desire for secrecy in light of the press leaks and grilled Sisco on certain portions of the agreement, like the Pershing missiles and oil commitments to Israel. Sisco remained tight-lipped in open session, but he claimed to be willing to offer more discussion in executive session. Thus, several representatives indicated their hope that the Committee could meet in executive session before voting on a joint resolution.

The committee must have been satisfied with the answers it received. On October 2, the committee discussed a resolution co-sponsored by Morgan and ranking minority member Senator William Broomfield (R-Michigan) permitting U.S. participation in the Sinai earlywarning station. After adopting four amendments, Morgan was instructed to introduce the draft as a joint resolution, and the measure passed the Committee the following day by a unanimous vote, 31-0. ${ }^{70}$ On October 8, the joint resolution passed the House, 341-69.

The two-day hearings of the Senate Foreign Relations Committee were more detailed than in the House, in part because the Senate Foreign Relations Committee had voted to make public the U.S. secret agreements just days before the Senate hearings and therefore was able to ask more searching questions in open session. Fittingly, the first witness was Abourezk. Fittingly because he had chaired the subcommittee review of executive agreements, and fittingly because he was the first Arab-American U.S Senator. ${ }^{71}$ Abourezk reminded the committee that "as representatives of the people in this country" the pending Senate decision "must not be made lightly, without debate, nor can it be made in secret, or with unconsiderable haste, in spite of the

\footnotetext{
${ }^{69}$ Ibid., 18.

70 "To Implement the United States Proposal for the Early-Warning System in Sinai," Report of the Committee on International Relations together with Supplemental and Additional Views on House Joint Resolution 683, October 6, 1975 (Washington: U.S. Government Printing Office), p. 2.

71 Abourezk's parents were Lebanese.
} 
clamoring of the editorial writers and those in the administration who might want it that way."72 The congressional debate and openness of American foreign policy were especially important for Abourezk, who believed "the Sinai agreement is a major benchmark, a plateau of involvement by the United States at a level not reached before." ${ }^{.73}$ Asked if he supported the portion of the agreement that provided for American personnel in the Sinai, Abourezk rejected the proposal for two main reasons. First, he felt that putting "Americans in the middle of the two combatants in the Middle East" was unwise and unnecessary because "there are other technicians in the world aside from American employees who can listen and who can run electronic gear just as well as our people can." ${ }^{74}$ Second, Abourezk regarded the Sinai II agreement as a step in the wrong direction, one that furthered the risk of war because it did not force Israel to give up more territory, and he therefore opposed the agreement generally. ${ }^{75}$ While Abourezk's unfavorable opinion of Sinai II was echoed by George Ball, and to a lesser extent George McGovern, the general feeling of the Senate was that any agreement was better than no agreement, which could potentially ignite another war.

Although Abourezk had chaired the subcommittee that reviewed the executive agreements legislation, Senator Thomas Eagleton (D-Missouri) devoted more of his discussion to the constitutionality of executive agreements than Abourezk. His comments were directed at "the status of international agreements consummated in the absence of congressional approval," which was at the heart of the 1975 debate about executive agreements. ${ }^{76}$ Eagleton pointed out

\footnotetext{
72 "Early Warning System in Sinai," Hearings before the Committee on Foreign Relations, United States Senate, Ninety-Fourth Congress, First Session on Memoranda of Agreements between the Governments of Israel and the United States, October 6 and 7, 1975 (Washington: U.S. Government Printing Office, 1975), p. 3.

${ }^{73}$ Ibid.

${ }^{74}$ Ibid., 5 .

${ }^{75}$ Ibid., 1-17. Abourezk was not alone, as several Senators and other witnesses voiced their concerns about an interim agreement that could paralyze, rather than advance, the Arab-Israeli peace process (George McGovern and George Ball, in particular).

${ }^{76}$ Ibid., 198.
} 
that the Case Act originally aimed to provide Congress with a legislative veto within the first 60 days of the agreement - just like the Ervin bill - but the House did not agree. Thus, the Case Act ended up being a compromise that fell far short of the Senate's hope, especially Eagleton's, and merely required the White House to report all executive agreements. ${ }^{77}$ The absence of the legislative veto, according to Eagleton, had led to “the Executive's usurpation of the Senate's treaty power." ${ }^{78}$ It was Eagleton's hope that the executive agreements with Israel and Egypt would create "a renewed effort to provide Congress with the mechanism necessary to reassert our legitimate powers in this area." ${ }^{79}$ In the end, Eagleton told the Committee that the executive agreements should have been submitted as treaties, but he still offered his support for the resolution that provided for the early-warning system. ${ }^{80}$

Kissinger appeared immediately after Eagleton and met with the Committee for a lengthy session, during which he defended the executive agreements. Kissinger pointed out that some of the executive agreements were binding, while others were assurances of "good faith"; however, the White House refused to make public Legal Adviser Monroe Leigh's memorandum, which discussed the legality and extent of commitments of the U.S. government for each of the separate executive agreements. ${ }^{81}$ In response to Leigh's memorandum, the Assistant Council for the Office of Legislative Counsel, Michael J. Glennon, responded that of the four secret agreements, one was a valid executive agreement, two were problematic, "and one was beyond the power of the President to enter into without the advice and consent of the Senate." ${ }^{\prime 2}$ Despite reservations, the Senate Foreign Relations Committee recommended the passage of H. J. Resolution 683 on

\footnotetext{
${ }^{77}$ Ibid.

${ }^{78}$ Ibid.

${ }^{79}$ Ibid., 198-99.

${ }^{80}$ Ibid., 200.

${ }^{81}$ Ibid., 233. Unfortunately, because the secrecy attached to the legal assessment was not lifted, one can only wonder which agreements were considered binding and which were not.

${ }^{82}$ U.S. Senate, Subcommittee on Separation of Powers, Hearings, Congressional Oversight of Executive Agreements - 1975, 94th Congress, p. 396.
} 
October 7. Two days later, the Senate voted 70-12 in favor of the resolution, which was signed into public law by Ford on October 13, 1975.

The joint resolution passed by Congress fairly represented the larger debate about executive agreements in 1975. Congress passed a joint resolution that allowed for the technicians, but included three important safeguards. First, the resolution required the President to provide Congress with written updates every six months in order to keep Congress apprised of any developments and the possibility of withdrawing U.S. personnel as soon as possible. Second, a concurrent resolution could force the President to recall the technicians, which extended the thinking of the War Powers Act to include U.S. civilian personnel. Third, the resolution included a final section that explicitly stated that approval of the early-warning station did not mean approval of any other agreements. The statement neither rejects nor accepts the executive agreements, but rather takes no action on them; section 5 states, "The authority contained in this joint resolution to implement the 'United States Proposal for the Early Warning System in Sinai' does not signify approval of the Congress of any other agreement, understanding, or commitment made by the executive branch. ${ }^{, 83}$ By including the section, Congress voiced its displeasure to the White House about executive agreements and still preserved the most essential part of Sinai II U.S. participation in an early-warning. Congress was unable to pass legislation restricting all executive agreements, but with Sinai II and H. J. 683, Congress discovered it could still significantly challenge executive agreements on a case-by-case basis, and particularly in terms of aid and deployment of U.S. personnel, not just troops.

However, although Congress reserved a right to challenge the executive agreements, it never did. Regarding financial incentives, Congress essentially "approved" of the aid packages to ${ }^{83}$ http://www.gpo.gov/fdsys/pkg/STATUTE-89/pdf/STATUTE-89-Pg572.pdf 
Israel and Egypt by allocating significant amounts to both countries in the next fiscal year. Representative Morgan and six other members of the House Committee on International Affairs "traveled to the Middle East area in January 1976 to obtain information in connection with legislation before the committee," which dealt with aid to the Middle East. ${ }^{84}$ Most important to the group of representatives was a sincere desire for peace in Egypt and Israel, and the mission was satisfied with its findings. "We are pleased," stated the report, "from our talks in both Israel and Egypt, with the desire for peace manifest in both capitals ... We believe that the economic interests of each country provide a further strong incentive for peace, and that assistance from the United States to both is a worthy investment toward an essential Middle East settlement." ${ }^{" 85}$ Sinai II did in fact lead to another peace agreement, though not the one hoped for by Congress. Instead of a multilateral peace, the Arab-Israel peace process evolved into a bilateral peace agreement between Israel and Egypt at Camp David a few years later (1978-79), while the main issues of the conflict (Palestinians and borders) were not resolved.

From the perspective of the White House, the Sinai II agreement must have been bittersweet. On the one hand, Ford and Kissinger were able to get another agreement between Israel and Egypt, the prospects of which seemed quite dim the previous March. But on the other hand, Congress challenged the White House on virtually every meaningful point, took over five weeks to permit U.S. technicians in the Sinai, and refused to endorse the executive agreements aside from the technicians. Although congressional disapproval cannot undo an executive agreement (unless a joint resolution secures congressional participation and allows for such action), Congress sent the White House a clear message - U.S. foreign relations requires

\footnotetext{
84 "Peace Efforts in the Middle East Area," Report of a Study Mission to the Middle East, January 3-16, 1976 (Washington: U.S. Government Printing Office, 1976), Foreward. Unfortunately, Morgan was unable to join the group in Egypt and Israel due to "a mishap in Naples, requiring medical attention" (2).

${ }^{85}$ Ibid., 9.
} 
cooperation between the executive and legislative branches. On top of that, the congressional approval of technicians included a possible legislative veto through a concurrent resolution similar to the War Powers Act. When talking to Ford about Congress, Kissinger once complained, "What they are doing to the Sinai agreement is unbelievable. It is the greatest achievement since the opening to China and all that is happening is they are pissing all over it." ${ }^{\prime 86}$ While Kissinger probably overstated the significance of Sinai II, one can understand why he felt Congress was watering-down the executive agreements.

The judicial branch has played a small, yet pivotal role in shaping the nature of executive agreements. The Supreme Court has consistently ruled in favor of Presidential power in foreign affairs, convincingly citing the Constitution's various provisions that vest significant power in the President. In 1975, Assistant Attorney General Scalia informed the executive agreements subcommittee that basically, due to Constitutional deficiencies and a number of previous rulings on the matter, the Court was unwilling to validate any bill that restrained the power of the executive in foreign affairs. Of course if the Court had been willing to establish new precedence and allow for a legislative veto of an executive agreement, then the story would be much different. The power of Congress to direct American foreign policy would have grown quite noticeably, especially relative to the White House, and American foreign policy could have a much different look to it. At the end of the day, the Supreme Court must give its consent to legislation, if challenged, and the Court left its mark on H. J. Resolution 683 and the Executive Agreements Review Act of 1975 through its dialogue with both the executive and legislative branches.

\footnotetext{
${ }^{86}$ Memorandum of Conversation, President Gerald Ford, Henry Kissinger, and Brent Scowcroft, September 26, 1975, Memcons, Box 15, September 26, 1975 - Ford, Kissinger, Gerald R. Ford Library.
} 
Although the Executive Agreements Review Act of 1975 ultimately failed to gain support, through the War Powers Act of 1973 and H. J. Resolution 683 of 1975, Congress has established the precedence necessary to challenge the power of the President to enter into potentially significant agreements that constitute national commitments. While the President has the right to negotiate and agree to executive agreements, Congress still maintains the right to essentially veto that action if the situation involves aid packages or U.S. personnel abroad. Even if the President promises a certain amount of aid to a country, Congress must still "authorize" the agreement through direct legislation or its appropriations power the following year. Additionally, if the President commits U.S. troops to a foreign conflict, Congress can still deny the President after 60 days, or potentially sooner, if Congress were so bold as to pass a concurrent resolution demanding the President to withdraw troops. One can only wonder if the Court would consider the concurrent resolution, if challenged by the executive branch, to be a legislative veto, especially in light of the 1983 Court decision in INS v. Chadha that declared the legislative veto unconstitutional.

Nevertheless, the striking feature of the congressional response to Sinai II is that the discussion was framed by constitutionalism at least as much as by foreign policy concerns. While some members of Congress questioned the logic behind Kissinger's diplomatic achievement in terms of the Arab-Israeli peace process, greater concern was voiced about perceived executive abuses in the aftermath of Watergate and the Vietnam War. Looking through the lens of the Executive Agreements Review Act of 1975, the tension between the White House and Capitol Hill explains, at least in part, the reaction of Congress to Sinai II and the language employed in the H. J. Resolution 683 (1975). 


\section{Chapter 8: \\ Conclusion}

The paradox of the Nixon and Ford years is that even though the two presidents were very critical of the Israelis at times, nonetheless, the special relationship between the United States and Israel deepened during their presidencies. Nixon and Ford were the first presidents who did not enjoy the same control over U.S.-Israel policy as their predecessors did. Of course, Nixon's and Ford's predecessors did not have to deal with an activist, pro-Israeli Congress, and a much more powerful pro-Israel lobby. In that sense, Nixon and Ford were having to deal with a new problem, and without any historical experience to go on in this regard. At the end of the day, both presidents basically threw up their hands and realized that U.S. policy would become more pro-Israeli, like it or not, and going with that development was the path of least resistance.

The United States Congress - and especially the Senate - played a crucial role in reshaping U.S.-Israel relations during the Nixon and Ford presidencies. When Nixon entered the White House in early 1969, he planned to pursue a more evenhanded policy in the Middle East than his predecessor, Lyndon Johnson. But a developing bloc of conservative support in Congress, led by Senator Henry "Scoop” Jackson, pushed Nixon hard to open the U.S. arsenal to the State of Israel. The Jackson Amendment of 1970 authorized the President to sell Israel up to \$500 million of weaponry on the most favorable credit terms available. Yet Nixon declined to use the broad powers of the Jackson Amendment when he submitted the budget proposal in early 1971. He feared that arming Israel too much would create a fortress mentality, thereby undercutting peace negotiations. Not until the 1973 Arab-Israeli war did the U.S. send large transport helicopters, "Cobra" attack helicopters, and various types of missiles. Israel finally managed to secure a massive, multiyear arms arrangement with the U.S. as part of the Sinai II disengagement agreement in 1975, anything but an evenhanded policy. Vocal support from the 
legislative branch, marked especially by the "spirit of the 76" - perhaps the most important letter ever written regarding U.S.-Israel relations - figured largely into that development. The Israeli embassy, and especially Simcha Dinitz who proposed such a letter, played a pivotal role in reworking the contours of the special relationship. For the U.S., a steady stream of military and economic aid, along with unwavering political support for Israel, has followed ever since.

When Gerald Ford left Washington in early 1977, he left the incoming President - Jimmy Carter - a powerful alliance between the U.S. and Israel that would bedevil Carter and his administration, just like Nixon and Ford, when pushing for peace agreements. According to Morris Amitay, Executive Director of the American Israel Public Affairs Committee (AIPAC) from 1974 to 1980, Congress continued to play a crucial role during the Carter years and the search for peace in the Middle East. Following the death of Carter's Secretary of State Cyrus Vance in 2002, Amitay commented that Israeli activists did not interact much with Vance. "The watchword then was to use Congress to influence policy," said Amitay. ${ }^{1}$

The fall of Richard Nixon, along with a drastic drop in public confidence in the Presidency, invited the type of congressional involvement necessary to shape U.S. foreign relations with Israel. The Constitution protects the President's right to conduct the foreign affairs of the United States. And during the Cold War the President's power in conducting U.S. foreign policy grew considerably. But the Vietnam War forced a reconsideration of that power, and Nixon's illegal activities and subsequent resignation highlighted the need for greater congressional participation. The reaction to presidential policies in Southeast Asia revealed the inherent power of Congress to challenge executive control of U.S. foreign relations, as Congress,

\footnotetext{
1 "Cyrus Vance Dies at 84," Jewish Telegraphic Agency, January 14, 2002, accessed January 16, 2016, http://www.jta.org/2002/01/14/life-religion/features/cyrus-vance-dies-at-84.
} 
reflecting the popular mood and will of the people, entered into one of its most active periods of influencing U.S. foreign policy.

Just as the Congress reflected public opinion regarding the Vietnam War, it also reflected strong public support for Israel. Both the Jackson Amendment of 1970 and the Senate letter from May 1975, in all likelihood, better reflected the public mood than did President Ford's freeze on aid to Israel. Yet Ford, like Nixon and Kissinger, recognized that without the leverage of withholding arms to Israel, the U.S. would be too weak to extract the types of concessions from Israel necessary to bring about lasting peace agreements. Without the ability to withhold critical weapons deliveries or follow a program separate from Israel, a fait accompli with Sinai II, the United States ended up following the policies of Israel much more than Israel ended up following the policies of the United States, with respect to the Arab-Israeli peace process.

Gerald Ford, who lacked an electoral mandate, ended up navigating the most ambitious U.S. program of diplomacy in the Middle East to date. In the process, the U.S. Congress and Israeli officials managed to steer U.S. foreign policy into a firmer special relationship between the United States and Israel, and in a way that undermined some of the executive branch's foreign policy goals in the region. In order to systematically implement a more evenhanded course, which Ford clearly meant to do, evidenced especially by reassessment, Ford needed to act from a much stronger position - like Eisenhower in 1956 at Suez. If one considers a counterfactual - if Watergate had never happened and Nixon continued into a powerful second term - one has to imagine that if given the opportunity, Richard Nixon would have made Israel play ball according to the rules of the U.S. President. But that was not in the cards. The power of the U.S. Presidency had sunk to perhaps its lowest level, Congress took the lead in relations with 
Israel, and considering congressional assertiveness in U.S. foreign policy in general at this time, the two branches of government could not help but walk out of step.

The special relationship took off during the Nixon and Ford years, not just because of Nixon and Ford (Kissinger certainly advanced the relationship, too), but especially because of the U.S. Congress, a position in line with strong U.S. public support for Israel. Eisenhower refused to directly sell weapons to Israel, and instead sold radar equipment. Kennedy refused to sell offensive weapons, and instead sold antiaircraft systems. Johnson agreed to sell much more powerful weaponry, including tanks and Skyhawk jets, but declined to sell Phantoms until the very end of his presidency. That decision came in response to the Soviet Union's invasion of Czechoslovakia and vocal opposition from Congress, which foreshadowed Nixon's confrontations with the USSR in Egypt and Congress's insistence on more Phantom sales to Israel. Neither Nixon nor Ford intended to arm Israel to the teeth with little hope for a peaceful resolution to the Arab-Israeli conflict. But that was the precise result of the Sinai II agreement in 1975. Only fifteen years after Eisenhower agreed to sell radar equipment, the Ford administration gave Israel what it wanted - weapons, political support, and no pressure to move in a certain direction. That crucial development in U.S. foreign relations occurred, at least in part, because of congressional opposition to executive branch initiatives and policies.

My dissertation also highlights the important agency of non-U.S. actors in the making of foreign policy, which fits into a developing trend in historiography concerned with non-U.S. agency. ${ }^{2}$ Israeli officials connected to the Israeli embassy in Washington (especially Simcha

\footnotetext{
${ }^{2}$ In particular, James Siekmeier has similarly shown how a foreign ambassador (Bolivian Ambassador Victor Andrade Uzquiano) used diplomatic skill and an understanding of U.S. political culture to secure vital U.S. foreign aid. James Siekmeier, The Bolivian Revolution and the United States, 1952 to the Present (University Park, PA: Penn State University Press, 2011). Other works that demonstrate the importance of non-U.S. agency include Eric Paul Roorda, The Dictator Next Door: The Good Neighbor Policy and the Trujilo Regime in the Dominican Republic, 1930-1945 (Durham: Duke University Press, 1998); Kyle Longley, The Sparrow and the Hawk: Costa Rica and the United States during the Rise of Jose Figueres (Tuscaloosa: University of Alabama Press, 1997); Seth
} 
Dinitz) proved remarkably able to meet with and influence members of both branches of government, especially the legislative branch. Dinitz played a heretofore unappreciated role in the reassessment period. While the divided Israeli cabinet of Yitzhak Rabin, Shimon Peres, and Yigal Allon all jockeyed for power, the former Foreign Minister and longtime politician Dinitz used the opportunity to take the lead in shaping Israel's relations with the United States from a position far removed from Jerusalem, and at a particularly important time.

Certainly international developments, like in Vietnam (and also elsewhere), impacted U.S. relations with the Middle East. Geopolitical concerns and pursuit of the national interest obviously drove foreign policy considerations, and a strong Israel - the main noncommunist, pro-U.S. stalwart in the Middle East - certainly benefitted the U.S. position in the Cold War. This was especially important given that the USSR continued to send military aid to the region, especially Syria and Iraq. But the perception of U.S. national security interests in the Middle East, by high-ranking political leaders in both the executive and legislative branches, played out in a domestic setting that witnessed an unusually active Congress. While the President leads in foreign affairs, Congress holds the power to demand participation when it sees fit. And by focusing on domestic politics and the activities of U.S. officials, people - more than abstract conceptions of power - drive the historical narrative. Importantly, the situation clearly illustrates that domestic politics and Congress always matter to some degree for U.S. foreign relations, and did particularly so during the 1970s.

Jacobs, America's Miracle Man in Vietnam: Ngo Dinh Diem, Religion, Race, and U.S. Intervention in Southeast Asia, 1950-1957 (Durham: Duke University Press, 2004); Sayuri Shimizu, Creating People of Plenty: The United States and Japan's Economic Alternatives, 1950-1960 (Kent: Kent State University Press, 2001); Zachary Karabell, Architects of Intervention: The United States, the Third World, and the Cold War, 1946-1962 (Baton Rouge: Louisiana State Press, 1999); and Jessica C. E. Gienow-Hecht, Transmission Impossible: American Journalism as Cultural Diplomacy in Postwar Germany, 1945-1955 (Baton Rouge: Louisiana State Press, 1999). 
The cementing of the U.S.-Israel special relationship, with a great deal of help from the pro-Israel lobby in Washington, was a mixed bag for both countries. On the one hand, it did a lot of good for both parties. At war since 1948, Israel and Egypt had been at the center of all three major conflicts thereafter: Suez in 1956-57, the 1967 war, and the 1973 war. The Sinai II agreement made possible the peace negotiations at Camp David only three years later. Israel managed to take Egypt of the war without having to give up any further territory aside from the Sinai Peninsula, and without addressing Palestinian grievances. Further, the U.S. rewarded Israel with the type of political and military support rivaled only by South Vietnam and Iran. For the United States, getting Egypt out of the war with Israel and out of the Soviet camp for good was a huge win in the Cold War, although Sadat wanted to sever ties with Moscow anyway.

Kissinger's diplomacy demonstrated that armed conflict would not force Israel (or the U.S.) to yield to such pressure. Given the powerful position of the U.S. in Israel, Iran, Saudi Arabia, and increasingly Egypt, the geopolitical situation in the Middle East in September 1975 looked quite good for American interests.

But on the other hand, the special relationship locked in place the very type of status quo that ensured future conflict. Quite certainly, Kissinger's diplomacy failed by not engaging the Palestinine Liberation Organization (PLO) or otherwise engaging Palestinians in the peace process, which doomed any prospect for a lasting peace arrangement. The civil war in Lebanon, which erupted around the same time as the signing of Sinai II, reminded all that Palestinian grievances would not simply fade away.

But importantly, step-by-step diplomacy facilitated the Camp David Peace Process that began in 1978 and resulted in a formal peace agreement between Israel and Egypt in 1979. Building upon the two disengagement agreements from 1974 and 1975, the two states agreed to 
officially end the state of war, with Israel agreeing to return the Sinai Peninsula and Egypt agreeing to make peace. Kissinger's diplomatic method - which impressively brought about normal relations between the U.S. and Egypt and U.S. and Syria, and also produced a political agreement between Israel and Syria - led directly to the end of war between Israel and Egypt. However the Palestinian question - intentionally avoided by Kissinger - remained unanswered at Camp David, and Sadat paid a high price for making a separate peace with Israel. Seen as willing to sacrifice the larger Arab cause, Egypt was kicked out of the Arab League from 1979 to 1989, and Sadat was assassinated by the terrorist group, Egyptian Islamic Jihad, in October 1981. While Israel and Egypt have managed to avoid any conflicts after agreeing to peace, the slow pace of the peace process after the Camp David Accords led directly to the First Intifada (19871991), and the failure to build on peaceful measures in the 1990s led to the Second Intifada (2000-2005); time will tell if the current tensions are the beginning of a Third Intifada.

Egyptian President Anwar Sadat was forced to walk a very fine line, pursuing peace with Israel and concomitantly assuring the Arab states it would continue to fight for Palestinian rights and the 1967 borders. It was Sadat, not Rabin, who took the greater risk; Sadat demonstrated he desired peace rather than war when he knowingly separated himself and Egypt from an Arab strategy based on "no peace, no negotiation" with Israel. Economic concerns were the primary catalyst for the decision. After assuming his duties as President of Egypt, Sadat was informed by Dr. Hassan Abbas Zaki, then Minister of Finance and Economy, that "the treasury was empty and we were 'almost bankrupt."'3 The cause, according to Sadat, was that the Egyptian government "had, with crass stupidity, copied the Soviet pattern of socialism, although we lacked the necessary resources, technical capabilities, and capital." ${ }^{\prime 4}$ The constant drain on an ill-

\footnotetext{
${ }^{3}$ Anwar el-Sadat, In Search of Identity: An Autobiography (New York: Harper \& Row, Publishers, 1977), 214.

${ }^{4}$ Sadat, 213.
} 
conceived economic structure was obviously defense spending. As long as Israel remained in the Sinai, the Egyptian military had to be heavily funded for the possibility of war. The wars in 1967 and 1973 showed that surprise was to the aggressor's advantage, so the potential defender needed to be prepared. But if Sadat could somehow bring peace to Egypt, he would no longer need to allocate excessive funding for defense purposes. Sadat could then work to fix an economy that, five days before the October War, "had fallen below zero."5

For the U.S., step-by-step diplomacy aimed for improved relations with the Arab world, and a peace program to allow Israel to eventually remove itself from the occupied territories. But the special relationship, built on political and military support for Israel, undermined both objectives. When Kissinger traveled to the Middle East and assured regional leaders that step-bystep diplomacy aimed for a peaceful, acceptable resolution to the Arab-Israeli conflict, he linked the outcome of the peace process to the health of U.S.-Arab relations. Since the 1970s, U.S. relations with both Israel and Egypt have been good. But regional dissatisfaction with U.S. policies (in particular, pro-Israel policies) has largely contributed to a pervasive antiAmericanism coming from many areas of the Middle East, and beyond.

Moreover, the U.S. has continually armed both Arabs and Israelis while proving unable to lead the peace process to a satisfactory conclusion, and at times weapons sales and peace discussions happen simultaneously. That, naturally, has necessitated more diplomacy and more weapons sales, with results that continue the ongoing cycle. A nearly identical point was made by a seventh-grade social studies class from Trinity Lutheran School in Wahiawa, HI. In a letter sent to Senator Hiram Fong (R-HI) on March 10, 1975, the students questioned why the U.S. was pursuing diplomacy and at the same time training Israeli and Arab soldiers how to fire missiles.

\footnotetext{
${ }^{5}$ Sadat, 215.
} 
The class wondered, "Why are we doing this? On the one hand we are sending Kissinger to the Middle East to help bring peace and on the other we are teaching both sides how to fire missiles." ${ }^{\prime 6}$ The United States played Cold War politics while trying to mediate a regional dispute, all while taking a pro-Israel position. The situation was bound to be problematic for all parties involved.

This dissertation aims to correct, at least in part, the imbalance in literature that devotes near-exclusive attention to presidential policies. Of course domestic politics and the U.S. Congress always impact the foreign policy of a democracy. But in the case of U.S.-Israel relations, focusing on the interplay of domestic and foreign politics, and extrapolating the impact of Congress on U.S. foreign policy, has particular relevance. The significant changes in U.S.Israel relations during the Nixon and Ford Presidencies - the tightening of the special relationship - had a big influence on U.S.-Middle East relations, and U.S. foreign relations more broadly.

${ }^{6}$ Letter from Social Studies Class 7A, Trinity Lutheran School to Senator Hiram Fong, March 10, 1975, National Archives II, Record Group 59, Container \#58C, Folder - P750058-1499 thru P750058-1596, Document 1557. 


\section{Bibliography}

\section{Primary Sources}

Lyndon Johnson Presidential Library

National Security Files, National Security Council History, Papers of LBJ

Richard Nixon Presidential Library

National Security Council Files, Harold H. Saunders Files/Middle East Negotiation Files

National Security Council Files, Henry A. Kissinger Office Files, Country Files - Middle East

National Security Council Files, Henry A. Kissinger Office Files, HAK Trip Files

National Security Council Files, Presidential/HAK MEMCONS

\section{Gerald Ford Presidential Library}

Max L. Friedersdorf Papers

Memcons

National Security Adviser: Memoranda of Conversations, 1973-1977

National Security Adviser: NSC Meeting File

NSC Press and Congressional Liaison Staff: Files, 1973-1976

Presidential Country Files for Middle East and South Asia, 1974-1977

University of Washington

Henry "Scoop" Jackson Papers

University of Arkansas

J. William Fulbright Papers

\section{Princeton University}

George McGovern Papers

\section{University of South Dakota}

James Abourezk Papers

National Archives I and II

Record Group 46: Records of the U.S. Senate

Record Group 59: Records of the Department of State

Record Group 233: Records of the United States House of Representatives

\section{Israel State Archives}

Ministry of Foreign Affairs - Office of the Chief Executive Officer

Ministry of Foreign Affairs - Office of the Foreign Minister

\section{Billy Graham Center Archives}

Papers of Roy Gustafson 


\section{Government Publications}

"Aid to Israel Legislation Sails Through Congress." CQ Almanac 1973, 29th Edition. Washington DC: Congressional Quarterly, 1974.

"Early Warning System in Sinai." Hearings before the Committee on Foreign Relations, United States Senate, Ninety-Fourth Congress, First Session on Memoranda of Agreements between the Governments of Israel and the United States, October 6 and 7, 1975. Washington: U.S. Government Printing Office, 1975.

"The Middle East." A Report by Senator Charles H. Percy to the Committee on Foreign Relations United States Senate, April 21, 1975. Washington: U.S. Government Printing Office, 1975.

"Middle East Agreements and the Early Warning System in Sinai." Hearings of the Committee on International Relations for the House of Representatives, Ninety-Fourth Congress, First Session on The Middle East Agreements and Legislation to Implement the United States Proposal for the Early-Warning System in Sinai. Washington: U.S. Government Printing Office, 1975.

"Peace Efforts in the Middle East Area." Report of a Study Mission to the Middle East, January 3-16, 1976. Washington: U.S. Government Printing Office, 1976.

"Priorities for Peace in the Middle East." Hearings Before the Subcommittee on Near Eastern and South Asian Affairs of the Committee on Foreign Relations, United States Senate, Ninety-Fourth Congress, First Session on the Arab Israeli Dispute: Priorities for Peace, July 23, and 24, 1975. Washington: U.S. Government Printing Office, 1975.

"Realities of the Middle East." A Report by Senator George S. McGovern to the Committee on Foreign Relations United States Senate, May 1975. Washington: U.S. Government Printing Office, 1975.

"To Implement the United States Proposal for the Early-Warning System in Sinai." Report of the Committee on International Relations together with Supplemental and Additional Views on House Joint Resolution 683, October 6, 1975. Washington: U.S. Government Printing Office.

U.S. Senate, Subcommittee on Separation of Powers, Hearings, Congressional Oversight of Executive Agreements - 1972, 92nd Congress. Washington: U.S. Government Printing Office, 1972.

U.S. Senate, Subcommittee on Separation of Powers, Hearings, Congressional Oversight of Executive Agreements - 1975, 94th Congress. Washington: U.S. Government Printing Office, 1975. 


\section{Congressional Record}

116 Congressional Record, 91st Congress, 2nd Session, 1970.

117 Congressional Record, 92nd Congress, 1st Session, 1971.

118 Congressional Record, 92nd Congress, 2nd Session, 1972.

\section{Foreign Relations of the United States}

Foreign Relations of the United States, 1964-1968, Vol. XIX, Arab-Israeli Crisis and War, 1967.

Foreign Relations of the United States, 1969-76 Vol. XXIV, Middle East Region and Arabian Peninsula, 1969-1972; Jordan, September 1970.

Foreign Relations of the United States, 1969-1976, Vol. XXIII, Arab-Israeli Dispute, 1969-1972.

\section{Memoirs}

Abourezk, James. Advise and Dissent: Memoirs of South Dakota and the U.S. Senate. Chicago: Chicago Review Press, 1989.

Ford, Gerald R. A Time to Heal: The Autobiography of Gerald R. Ford. New York: Harper \& Row, Publishers, 1979.

Kissinger, Henry. White House Years. Boston: Little, Brown and Company, 1979.

- Years of Upheaval. Boston: Little, Brown and Company, 1982.

- Years of Renewal. New York: Simon \& Schuster, 1999.

Meir, Golda. My Life. New York: G. P. Putnam’s Sons, 1975.

Nixon, Richard. The Memoirs of Richard Nixon. New York: Grosset \& Dunlap, 1978.

Rabin, Yitzhak. The Rabin Memoirs, Expanded Edition. Berkeley: University of California Press, 1996.

el-Sadat, Anwar. In Search of Identity: An Autobiography. New York: Harper \& Row, Publishers, 1977.

\section{Oral History}

Transcript of interview with Zvi Rafiah. Interviewed by Paul J. P. Sandal and Laura Blackburn. Stephen F. Austin State University, accessed 9 October 2015, http://www.sfasu.edu/heritagecenter/5381.asp. 


\section{$\underline{\text { Secondary Sources }}$}

\section{Books}

Abu-Jabir, Faiz S. American-Arab Relations from Wilson to Nixon. Washington D.C.: University Press of America, Inc., 1979.

Ahlberg, Kristin L. Transplanting the Great Society: Lyndon Johnson and Food for Peace. Columbia: University of Missouri Press, 2008.

Albin, Cecilia and Harold H. Saunders. Sinai II: The Politics of International Mediation (F P I Case Studies). Washington D.C.: Johns Hopkins University, School of Advanced International Studies, 1993.

Aronson, Shlomo. Conflict \& Bargaining in the Middle East: An Israeli Perspective. Baltimore: The Johns Hopkins University Press, 1978.

el Azhary, M.S. Political Cohesion of American Jews in American Politics. Lanham, MD: University Press of America, 1980.

Ball, George W. and Douglas B. Ball. The Passionate Attachment: America's Involvement with Israel, 1947 to the Present. New York: W.W. Norton \& Company, 1992.

Bard, Mitchell Geoffrey. The Water's Edge and Beyond: Defining the Limits to Domestic Influence on United States Middle East Policy. New Brunswick: Transaction Publishers, 1991.

Bass, Warren. Support Any Friend: Kennedy's Middle East and the Making of the U.S.-Israel Alliance. Oxford: Oxford University Press, 2003.

Ben-Zvi, Abraham. The United States and Israel: The Limits of the Special Relationship. New York: Columbia University Press, 1993.

- The Origins of the American-Israeli Alliance: The Jordanian Factor. New York, NY: Routledge, 2007.

Berman, Larry. No Peace No Honor: Nixon, Kissinger, and Betrayal in Vietnam. New York: The Free Press, 2001.

Bill, James A. George Ball: Behind the Scenes in U.S. Foreign Policy. New Haven: Yale University Press, 1997.

Brown, Seyom. The Crises of Power: An Interpretation of United States Foreign Policy during the Kissinger Years. New York: Columbia University Press, 1979.

Buheiry, Marwan R. U.S. Threats of Intervention Against Arab Oil: 1973-1979. Beirut: Institute for Palestine Studies, 1980. 
Chadda, Maya. Paradox of Power: The United States in Southwest Asia. Santa Barbara: ABCCLIO, 1986.

Chamberlin, Paul. The Global Offensive: The United States, the Palestine Liberation Organization, and the Making of the Post-Cold War Order. Oxford: Oxford University Press, 2012.

Chomsky, Noam. Fateful Triangle: The United States, Israel \& The Palestinians, Updated Edition. Cambridge: South End Press, 1999.

Citino, Nathan J. From Arab Nationalism to OPEC: Eisenhower, King Sa'ud, and the Making of U.S.-Saudi Relations. Bloomington: Indiana University Press, 2002.

Cleva, Gregory D. Henry Kissinger and the American Approach to Foreign Policy. London: Associated University Presses, 1989.

Daigle, Craig. The Limits of Détente: The United States, the Soviet Union, and the Arab-Israeli Conflict, 1969-1973. New Haven: Yale University Press, 2012.

Dickson, Peter W. Kissinger and the Meaning of History. Cambridge: Cambridge University Press, 1978.

Feuerwerger, Marvin C. Congress and Israel: Foreign Aid Decision-Making in the House of Representatives, 1969-1976. Westport, CT: Praeger, 1979.

Findley, Paul. They Dare to Speak Out: People and Institutions Confront Israel's Lobby. Chicago: Lawrence Hill Books, 2003.

Fisher, Louis. President and Congress: Power and Policy. New York: The Free Press, 1972.

- The Politics of Shared Power: Congress and the Executive, Fourth Edition. College Station, TX: Texas A\&M University Press, 1998.

- Constitutional Conflicts Between Congress and the President, Fifth Edition. Lawrence, KS: University of Kansas Press, 2007.

Franck, Thomas M. and Edward Weisband. Foreign Policy by Congress. Oxford: Oxford University Press, 1979.

Fulbright, J. William. The Arrogance of Power. New York: Random House, 1966.

- The Crippled Giant: American Foreign Policy and Its Domestic Consequences. New York: Vintage Books, 1972. 
Gat, Moshe. In Search of a Peace Settlement: Egypt and Israel Between the War, 1967-1973. New York: Palgrave Macmillan, 2012.

Gelvin, James L. The Israel-Palestine Conflict: One Hundred Years of War, Second Edition. Cambridge: Cambridge University Press, 2007.

Ghanayem, Ishaq I. and Alden H. Voth. The Kissinger Legacy: American-Middle East Policy. New York: Praeger, 1984.

Gienow-Hecht, Jessica C. E. Transmission Impossible: American Journalism as Cultural Diplomacy in Postwar Germany, 1945-1955. Baton Rouge: Louisiana State Press, 1999.

Ginor, Isabella and Gideon Remez. Foxbats over Dimona: The Soviets' Nuclear Gamble in the Six-Day War. New Haven: Yale University Press, 2007.

Golan, Matti. The Secret Conversations of Henry Kissinger. New York: Quadrangle, 1976.

Golden, Peter. Quiet Diplomat: A Biography of Max M. Fisher. New York: Cornwall Books, 1992.

Govrin, Yosef. Israeli-Soviet Relations 1953-1967: From Confrontation to Disruption. Portland, OR: Frank Cass, 1998.

Greene, John Robert. The Presidency of Gerald R. Ford. Lawrence: University of Kansas Press, 1995.

- The Limits of Power: The Nixon and Ford Administrations. Bloomington: Indiana University Press, 1992.

Hahn, Peter L. Caught in the Middle East: U.S. Policy toward the Arab-Israeli Conflict, 19451961. Chapel Hill: University of North Carolina Press, 2004.

- Crisis and Crossfire: The United States and the Middle East since 1945. Washington D.C.: Potomac Books, 2005.

Hanhimaki, Jussi. The Flawed Architect: Henry Kissinger and American Foreign Policy. Oxford: Oxford University Press, 2004.

Hendrickson, Ryan C. Obama at War: Congress and the Imperial Presidency. Lexington: University of Kentucky Press, 2015.

Hersh, Seymour M. The Price of Power: Kissinger in the Nixon White House. New York: Summit Books, 1983.

Irons, Peter. War Powers: How the Imperial Presidency Hijacked the Constitution. New York: Metropolitan Books, 2005. 
Isaacson, Walter. Kissinger: A Biography. New York: Simon \& Schuster, 1992.

Jacobs, Seth. America's Miracle Man in Vietnam: Ngo Dinh Diem, Religion, Race, and U.S. Intervention in Southeast Asia, 1950-1957. Durham: Duke University Press, 2004.

Johnson, Loch K. America as a World Power: Foreign Policy in a Constitutional Framework, Second Edition. New York: McGraw-Hill, 1995.

- The Making of International Agreements: Congress Confronts the Executive. New York: New York University Press, 1984.

Johnson, Robert David. Congress and the Cold War. Cambridge: Cambridge University Press, 2006.

- Lyndon Johnson and Israel: The Secret Presidential Recordings. Tel Aviv University, 2008.

Karabell, Zachary. Architects of Intervention: The United States, the Third World, and the Cold War, 1946-1962. Baton Rouge: Louisiana State Press, 1999.

Kaufman, Burton I. The Arab Middle East and the United States: Inter-Arab Rivalry and Superpower Diplomacy. New York: Twayne Publishers, 1996.

Kaufman, Robert Gordon. Henry M. Jackson: A Life in Politics. Seattle: University of Washington Press, 2000.

Klinghoffer, Judith A. Vietnam, Jews and the Middle East: Unintended Consequences. New York: St. Martin's Press, 1999.

Kochavi, Noam. Nixon and Israel: Forging a Conservative Partnership. Albany: State University of New York Press, 2009.

Korn, David. Stalemate: The War of Attrition and Great Power Diplomacy in the Middle East, 1967-1970. Boulder: Westview Press, 1992.

Krutz, Glen S. and Jeffrey S. Peake. Treaty Politics and the Rise of Executive Agreements: International Commitments in a System of Shared Powers. Ann Arbor: The University of Michigan Press, 2009.

Lehman, John. The Executive, Congress, and Foreign Policy: Studies of the Nixon Administration. New York: Praeger, 1974.

Lenczowski, George. American Presidents and the Middle East. Durham: Duke University Press, 1990. 
Lesch, David W. ed. The Middle East and the United States: A Historical and Political Reassessment, Second Edition. Boulder: Westview Press, 1999.

Little, Douglas. American Orientalism: The United States and the Middle East since 1945. Chapel Hill: The University of North Carolina Press, 2002.

Logevall, Fredrik and Andrew Preston, eds. Nixon in the World: American Foreign Relations, 1969-1977. New York: Oxford University Press, 2008.

Longley, Kyle. The Sparrow and the Hawk: Costa Rica and the United States during the Rise of Jose Figueres. Tuscaloosa: University of Alabama Press, 1997.

Louis, William Roger and Avi Shlaim, eds. The 1967 Arab-Israeli War: Origins and Consequences. New York: Cambridge University Press, 2012.

Mann, Thomas E., ed. A Question of Balance: The President, the Congress, and Foreign Policy. Washington D.C.: The Brookings Institution, 1990.

Mansour, Camille, trans. James A. Cohen. Beyond Alliance: Israel in U.S. Foreign Policy. New York: Columbia University Press, 1994.

Margolis, Lawrence. Executive Agreements and Presidential Power in Foreign Policy. New York: Praeger Publishers, 1986.

Mart, Michelle. Eye on Israel: How America Came to View Israel as an Ally. Albany: State University of New York Press, 2006.

Mazlish, Bruce. Kissinger: The European Mind in American Policy. New York: Basic Books, Inc., Publishers, 1976.

McLaurin, R. D. The Middle East in Soviet Policy. Lexington: D.C. Heath and Company, 1976.

McLaurin, R.D., Mohammed Mughisuddin, and Abraham R. Wagner. Foreign Policy Making in the Middle East: Domestic Influences on Policy in Egypt, Iraq, Israel, and Syria. New York: Praeger, 1977.

Mearshimer, John J. and Stephen M. Walt. The Israel Lobby and U.S. Foreign Policy. New York: Farrar, Straus and Giroux, 2007.

Mieczkowski, Yanek. Gerald Ford and the Challenges of the 1970s. Lexington: The University Press of Kentucky, 2005.

Montgomery, Bruce P. Richard B. Cheney and the Rise of the Imperial Vice Presidency. Westport, CT: Praeger, 2009. 
Morris, Roger. Uncertain Greatness: Henry Kissinger and American Foreign Policy. New York: Harper \& Row, 1977.

Muskie, Edmund S., Kenneth Rush, and Kenneth W. Thompson, eds. The President, the Congress, and Foreign Policy: A Joint Policy Project of the Association of Former Members of Congress and the Atlantic Council of the United States. Lanham, MD: University Press of America, Inc., 1986.

Novik, Nimrod. The United States and Israel: Domestic Determinants of a Changing U.S. Commitment. Boulder: Westview Press, 1986.

Oren, Michael B. Six Days of War: June 1967 and the Making of the Modern Middle East. Oxford: Oxford University Press, 2002.

- Power, Faith, and Fantasy: America in the Middle East, 1776 to the Present. New York: W. W. Norton \& Company, 2007.

Parker, Richard. The Politics of Miscalculation in the Middle East. Bloomington: Indiana University Press, 1993.

- The Six Day War: A Retrospective. Gainesville: University Press of Florida, 1996.

Pollock, David. The Politics of Pressure: American Arms and Israeli Policy since the Six Day War. Westport, CT: Greenwood Press, 1982.

Quandt, William B. Peace Process: American Diplomacy and the Arab-Israeli Conflict Since 1967, Third Edition. Washington D.C.: Brookings Institution, 2005.

- Decade of Decisions: American Policy Toward the Arab-Israeli Conflict, 1967-1976. Berkeley: University of California Press, 1977.

Rabie, Mohamed. The Politics of Foreign Aid: U.S. Foreign Assistance and Aid to Israel. New York: Praeger, 1988.

Reich, Bernard. Quest for Peace: United States-Israel Relations and the Arab-Israeli Conflict. New Brunswick, NJ: Transaction Books, 1977.

- The United States and Israel: Influence in the Special Relationship. New York: Praeger, 1984.

Ro'i, Yaacov and Boris Morozov, eds. The Soviet Union and the June 1967 Six Day War. Stanford: Stanford University Press, 2008.

Roorda, Paul. The Dictator Next Door: The Good Neighbor Policy and the Trujillo Regime in the Dominican Republic, 1930-1945. Durham: Duke University Press, 1998. 
Ross, Dennis. Doomed to Succeed: The U.S.-Israel Relationship from Truman to Obama. New York: Farrar, Straus and Giroux, 2015.

Rostow, Eugene V., ed. The Middle East: Critical Choices for the United States. Boulder: Westview Press, 1976.

Rubenberg, Cheryl A. Israel and the American National Interest: A Critical Examination. Urbana: University of Illinois Press, 1986.

Rudalevige, Andrew. New Imperial Presidency: Renewing Presidential Power after Watergate. Ann Arbor: University of Michigan Press, 2006.

Saunders, Harold H. Saunders. "The Middle East, 1973-1984: Hidden Agendas.” In The President, the Congress, and Foreign Policy: A Joint Policy Project of the Association of Former Members of Congress and the Atlantic Council of the United States, edited by, Edmund S. Muskie, Kenneth Rush, and Kenneth W. Thompson, 175-205. Lanham, MD: University Press of America, Inc., 1986.

- The Other Walls: The Arab-Israeli Peace Process in a Global Perspective, Revised. Princeton: Princeton University Press, 1991.

Savage, Charlie. Takeover: The Return of the Imperial Presidency and the Subversion of American Democracy. New York: Back Bay Books, 2007.

Schlesinger, Jr., Arthur. The Imperial Presidency. Boston: Mariner Books, 1973.

- War and the American Presidency. New York: W. W. Norton, 2004.

Schoenbaum, David. The United States and the State of Israel. Oxford: Oxford University Press, 1993.

Schulzinger, Robert D. Henry Kissinger: Doctor of Diplomacy. New York: Columbia University Press, 1989.

Shalom, Zaki. The Role of US Diplomacy in the Lead-Up to the Six Day War: Balancing Moral Commitments and National Interests. Portland, OR: Sussex Academic Press, 2012.

Sheehan, Edward R. F. The Arabs, Israelis, and Kissinger. New York: Reader's Digest Press, 1976.

Shimizu, Sayuri. Creating People of Plenty: The United States and Japan's Economic Alternatives, 1950-1960. Kent: Kent State University Press, 2001.

Shlaim, Avi. War and Peace in the Middle East: A Critique of American Policy. New York: Penguin Group, 1994. 
Siekmeier, James. The Bolivian Revolution and the United States, 1952 to the Present. University Park, PA: Penn State University Press, 2011.

Silkenat, James R. and Mark R. Shulman, eds. The Imperial Presidency and the Consequences of 9/11: Lawyers React to the Global War on Terrorism. Westport, CT: Praeger, 2007.

Small, Melvin. Democracy and Diplomacy: The Impact of Domestic Politics on U.S. Foreign Policy, 1789-1994. Baltimore: The Johns Hopkins University Press, 1996.

- At the Water's Edge: American Politics and the Vietnam War. Chicago: Ivan R. Dee, 2005.

Spanier, John and Joseph Nogee, eds. Congress, the Presidency and American Foreign Policy. New York: Pergamon Press Inc., 1981.

Spiegel, Steven L. The Other Arab-Israeli Conflict: Making America's Middle East Policy, from Truman to Reagan. Chicago: University of Chicago Press, 1985.

Stivers, William. America's Confrontation with Revolutionary Change in the Middle East, 19481983. New York: St. Martin's Press, 1986.

Sundquist, James L. The Decline and Resurgence of Congress. Washington D.C.: Brookings Institution Press, 1981.

Thornton, Richard C. The Nixon-Kissinger Years: Reshaping America's Foreign Policy, Second Edition. St. Paul, MN: Paragon House, 2001.

Tillman, Seth P. The United States in the Middle East: Interests and Obstacles. Bloomington: Indiana University Press, 1982.

Tivnan, Edward. The Lobby: Jewish Political Power and American Foreign Policy. New York: Simon \& Schuster, 1987.

Urofsky, Melvin I. We Are One! American Jewry and Israel. Garden City, NY: Anchor Press, 1978.

Vanetik, Boaz and Zaki Shalom. The Nixon Administration and the Middle East Peace Process, 1969-1973. Chicago: Sussex Academic Press, 2013.

Westad, Odd Arne. The Global Cold War: Third World Interventions and the Making of Our Times. Cambridge: Cambridge University Press, 2007.

Woods, Randall Bennett. Fulbright: A Biography. Cambridge: Cambridge University Press, 1995. 
Yaqub, Salim. "The Weight of Conquest: Henry Kissinger and the Arab-Israeli Conflict." In Nixon in the World: American Foreign Relations, 1969-1977, edited by Fredrik Logevall and Andrew Preston, 227-248. Oxford: Oxford University Press, 2008.

- Containing Arab Nationalism: The Eisenhower Doctrine and the Middle East. Chapel Hill: The University of North Carolina Press, 2004.

Yergin, Daniel. The Prize: The Epic Quest for Oil, Money \& Power. New York: The Free Press, 1991.

Zuboc, Vladislav M. Failed Empire: The Soviet Union in the Cold War from Stalin to Gorbachev. Chapel Hill: University of North Carolina Press, 2007.

\section{Journal Articles}

Adamsky, Dima P. "Disregarding the Bear: How U.S. Intelligence Failed to Estimate the Soviet Intervention in the Egyptian-Israeli War of Attrition." Journal of Strategic Studies, Vol. 28, Issue 5, 2005, 803-831.

- “'Zero-Hour for the Bears': Inquiring into the Soviet Decision to Intervene in the Egyptian-Israeli War of Attrition, 1969-70.” Cold War History, Vol. 6, No. 1, February 2006, 113-136.

Bar-Siman-Tov, Yaacov. "The United States and Israel since 1948: A 'Special Relationship'?" Diplomatic History, Vol. 22, Issue 2, Spring 1998, 231-262.

Blanga, Yehuda. "“The Russians are Coming, the Russians are Coming': American Management of the Crisis Associated with Ending the October 1973 War." Middle Eastern Studies, Vol. 49, Issue 4, 2013, 563-589.

Golan, Galia. "The Soviet Union and the Outbreak of the June 1967 Six-Day War." Journal of Cold War Studies, Vol. 8, No. 1, Winter 2006, 3-19.

Goldberg, Arthur J. "What Resolution 242 Really Said." American Foreign Policy Interests, Vol. 33, Issue 1, 2011, 41-46.

Graf, Rudiger. "Making Use of the 'Oil Weapon': Western Industrialized Countries and Arab Petropolitics in 1973-1974." Diplomatic History, Vol. 36, Issue 1, January 2012, 185208.

Grant, Philip A. "The Bricker Amendment Controversy." Presidential Studies Quarterly, Vol. 15, No. 3, Summer, 1985, 572-582.

Hahn, Peter L. "The View from Jerusalem: Revelations about U.S. Diplomacy from the Archives of Israel." Diplomatic History, Vol. 22, Issue 4, Fall 1998, 509-532. 
Heimann, Gadi. "From Friendship to Patronage: France-Israel Relations, 1958-1967." Diplomacy \& Statecraft, Vol. 21, Issue 2, June 2010, 240-258.

- "From 'Irresponsible' to 'Immoral': The Shifts in de Gaulle's Perception of Israel and the Jews." Journal of Contemporary History, Vol. 46, No. 4, October 2011, 897-919.

Jackson, Galen. "The Showdown That Wasn't: U.S.-Israeli Relations and American Domestic Politics, 1973-1975.” International Security, Vol. 39, No. 4, Spring 2015, 130-169.

Labelle, Jr., Maurice. "The Only Thorn: Early Saudi-American Relations and the Question of Palestine, 1945-1949." Diplomatic History, Vol. 35, Issue 2, April 2011, 257-281.

Levey, Zach. "The United States' Skyhawk Sale to Israel, 1966: Strategic Exigencies of an Arms Deal." Diplomatic History, Vol. 28, Issue 2, April 2004, 255-276.

- "Anatomy of an Airlift: United States Military Assistance to Israel during the 1973 War." Cold War History, Vol. 8, No. 4, November 2008, 481-501.

Little, Douglas. "The Making of a Special Relationship: The United States and Israel, 1957-68." International Journal of Middle East Studies, Vol. 25, No. 4, November 1993, 563-585.

Rodman, David. "Phantom Fracas: The 1968 American Sale of F-4 Aircraft to Israel." Middle Eastern Studies, Vol. 40, No. 6, November 2004, 130-144.

Schwartz, Thomas Alan. "Henry, ... Winning an Election Is Terribly Important': Partisan Politics in the History of U.S. Foreign Relations." Diplomatic History, Vol. 33, Issue 2, April 2009, 173-190.

Zernichow, Simen and Hilde Henriksen Waage. "The Palestine Option: Nixon, the National Security Council, and the Search for a New Policy, 1970." Diplomatic History, Vol. 38, Issue 1, January 2014, 182-209. 